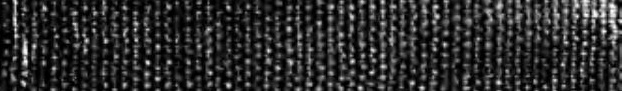
man WH Ham WH H H

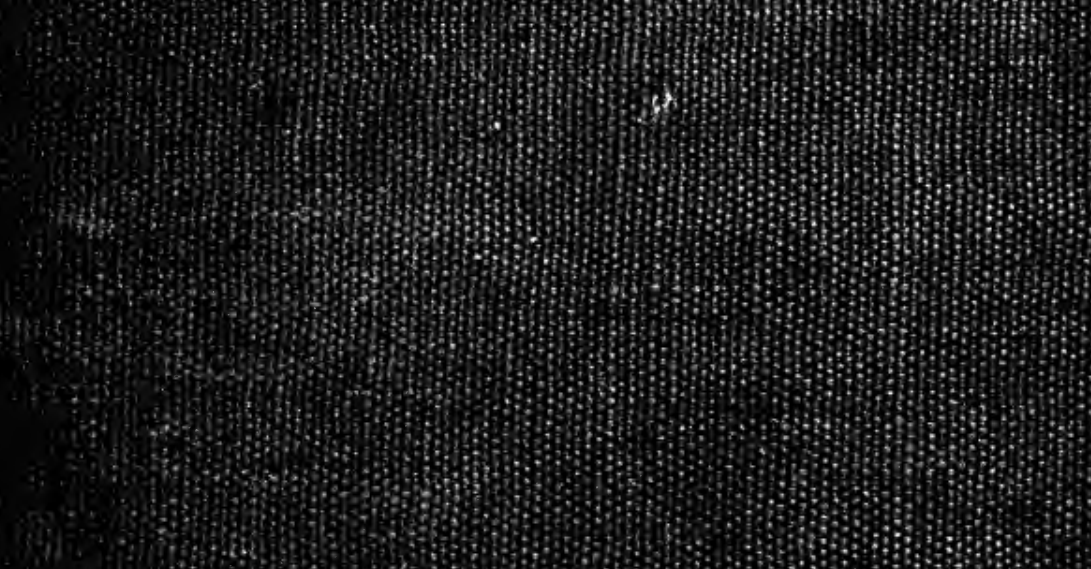
(1) 





\section{OUTLINES OF THE ECONOMIC HISTORY OF ENGLAND}



M5594n

\section{OUTLINES OF THE}

\section{ECONOMIC HISTORY OF ENGLAND}

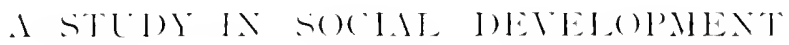

H. O. MEREDITH, M.A., M.Com.
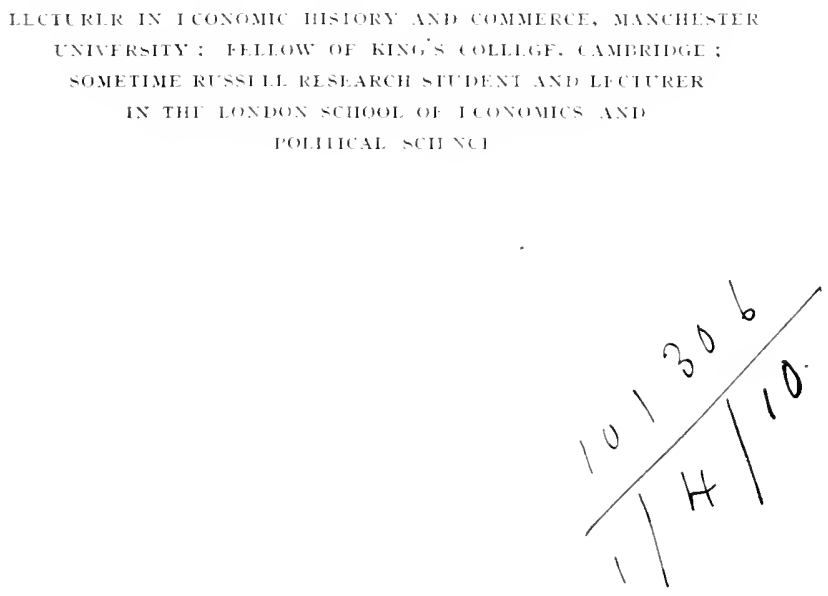

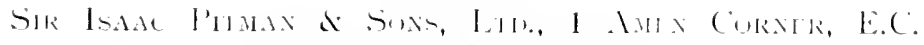
lishH AND NHW YoRk 
!'RINTED EY SIR LaAa PITMAN a Soxs, 1.TD.. LoNDox, litit ANI Xew Jurk. . 195 
TO

COLIEAGLES AXI TRIFNIS

IN THE

DEPARTMEXTS OF HISTORY ECONOMIO AND COMHERCE $A T$

M.NOIIESTER TNITERSITY 



\section{Prefice}

In this book I have relied almost exelusively on the researches of

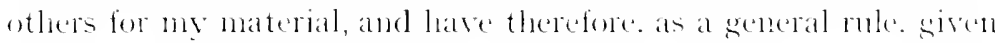
references only when quoting the words of previons writers. My chief obligatione it is hardly necessary to state. is to Dr. Cunningham's "Growth of English Industry and Commeree" and I have freen especially fortmate in writing after the publication of the entarged edition of this great work. Amongst a nundere of foreden: looks I an most indebted to 1)r. Steffen's " Cieschichte der Englis-

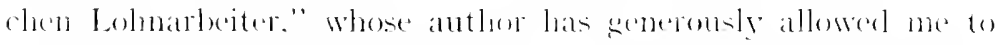
publish the chats at harhed to Appendix I. I have also to arkonledge the kindness of several friends who have ratel portions of the bosk in manuscript or prout, and assisted me with valuable criticisms and smgerstions.

I1. (). II. 



\title{
CON'I'EN'TS
}

\author{
BOOK I

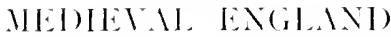 \\ $106(3-1972$
}

CHAI.

I. AENERAL SERVEY

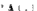

II. THE MANURLAL SYSHLM . . .

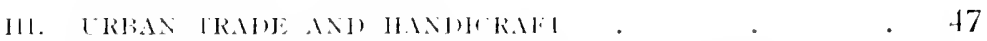

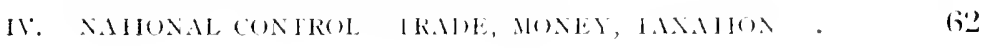

13()) K 11

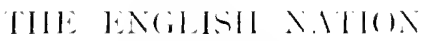

$1272-160: 3$

1. GENERAL SLRVEY . . . . . T9

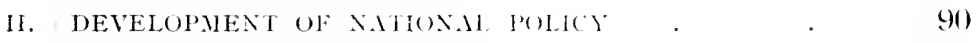

HI. TRANSITION IN AGRICLLTIRE • • . IOS

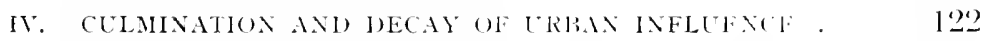

r. THE GENESIS OF CAPITALASM . . 141

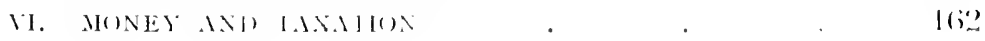

$\mathrm{BOO}) \mathrm{K} 11 \mathrm{I}$

THE ANTE(EDENTS OI THE INUISTRIII.

REVOLLTION

$1603-1760$

I. GEXERAL SERVEY . - . $\quad$. $\quad$. 181

I1. MGRICULTLRE, INDLSTRY, ANI FUREIGN TRAUE . 20)

111. FINAXCE AXI TAXATIOX . . . 215 


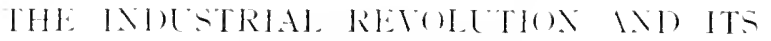
CONSEUETIES

$17(60)-19(10)$

$H A F^{2}$

I. 1,ISERII STRYY.

$2: 30$

IH. IIIE AREAJ IOTFNTENS . . 242

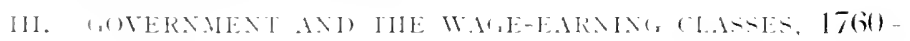

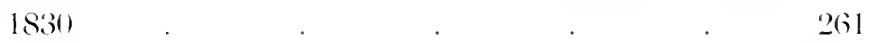

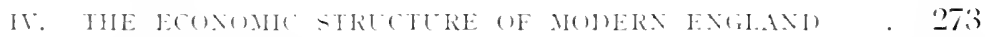

․ TIL M IANIARI) OF LIFE . . 2SE

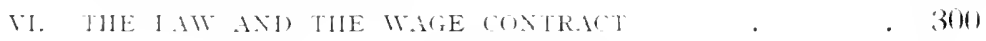

r11. MONET, (REDIT, ANI FLECTEAHONS . \$16

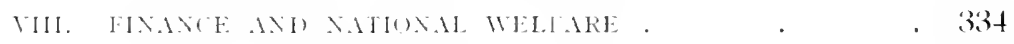

APIEXIHX (1) WAIES ANI PJUEE . 340

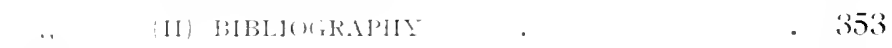

MINA . . . . . 


\section{Economic History of England}

\section{INTRODUCTION}

Ix common with other provinces of the Empire, Britain, during the Roman occupation, reached a considerable degree of economic development. Large urban centres were connected by an excellent system of roads, and along these roads the frequent remains of villas testify to the luxurious living of the wealthy classes. But between the econonic organisation of Britain at that period and England in the nineteenth century there is an important difference. Hardly anyone in the country now produces any considerable proportion of the objects which he himself consumes. The produce of a rural village, like the produce of an urban centre, is marketed beyond the borders of the village, and the village draws from without the supplies consumed by its members. In Roman Britain, on the other hand, it seems probable that the workers in each small area produced locally the food and clothes and housing which they consumed, and that the goods which were drawn from them brought back no returns of material wealth, but provided only the luxurious expenditure of the governing class. The requirements of this class-native chiefs and Roman officials and speculators-and of subordinate bureancrats and soldiers produced the urban centres and the trade of the country. From the rural districts they drew supplies of food and raw materials by rents and taxation, in some cases also by the direct exploitation of slave labour. These supplies maintained their craftsmen and personal attendants, or were exported to pay for the luxuries which had to be provided from a distance.

The economic effects of the Saxon conquest are in some respects clear, in others exceedingly obscure. In the first place it is evident that urban life and commerce were swept away. Where the 
fortifications of the towns protected them from direct attack, they bled to death by the interruption in their supplies from the country. But the disappearance of the towns under the circumstances would not necessarily lead to any considerable economic change in the country districts. Each locality could continue to produce for itself as it had produced before, with the simple difference that it would no longer have to part with some of its produce to the outside world. If a Saxon pirate stepped into the shoes of the Roman administrator or native chief there might be no substantial alteration in the economic position of the mass of the people. It is at least possible that this occurred in many districts; it has been argued that it was the rule throughout the country. There is, however, evidence that over the greater part England the Saxon conquest implied a far more serious uphe: The suppression of the Celtic language and religion, together witl predominance of Teutonic place names, suggests an actual displ ment of population, not merely the introduction of foreign lords, this view is supported by what little is known of the characte the Conquest. The new-comers spread gradually over the cou diming a period of centuries. Raids on the coast and up the ri produced the first settlements, and from these settlements $r$ : were made up country as new invaders arrived from the Contir. or each generation reached maturity. Between Saxon and Bri areas at any one moment there must have existed an aln depopulated border, as between Scotland and England at a lc date, and this border being pushert forward orer the countiug gonf tion by generation would involve, sooner or later, destruction : reconstruction in almost every district. The argument advanced Gibbon that the conquerors would be careful to preserve everyth that would be useful to them lias its force. But in so far as 1 Conquest took place along the lines indicated, cattle, property, $\mathrm{r}$. and women would be seized by raids and incorporated in the rec struction, the society of which they lat formed part being resols into its prime elements. That the Conquest was at least a mo serious matter for the British than some writers have suggest seems to be proved by their wholesale emigration to Armoric Some weight also must be given to the traditions preserved by Bec At the same time, our view leaves room for the survival in man districts of pre-Teutonic organisation. In many cases a bri 
period of systematic conquest resulted in the rapid incorporation within the Saxon area of districts which had suffered little from border warfare and raid. Here, as seems to have been the case in Kent, little change may have occurred beyond a change of masters in the British villages, though doubtless colonies of Germans would be established in and amongst them. Especially in the later periot of the Conquest, when considerable Saxon kingdoms were already established, this would be the more natural process. We should expect a larger survival of British institutions in the West generally, and in Cornwall and those parts of Cumberland and Westmoreland (Strathclyde) which were last incorporated we should anticipate a more complete survival than elsewhere.

Meitzen's ${ }^{1}$ comparative study of survey maps for this and other countries corroborates these views. His researches indicate that over the greater part of England types of village settlement, similar to those in Germany, predominate, the most common being the "nucleated" village. But in Cornwall and Devonshire, on the Welsh border, in Cumberland and Western Westmoreland a type of settlement predominant in Wales and Ireland, namely, "the scattered homestead," occurs. He concludes that whereas the greater part of the country was actually resettled by the Saxons, the districts indicated, together with smaller areas in other parts of the country, remained British in population and organisation. In addition it may be supposed that the Saxon settlements incorporated a proportion of subject British which would be higher generally speaking in the West than in the South and East.

Whatever may be the bearing of Meitzen's researches on the racial problem, it is certain that the two types of settlement by "scattered homestead" and "nucleated village" respectively indicate an important difference of economic organisation. The origin and cause of the " nucleated village" is to be sought in " openfield" arable culture. Under this system there is no several ownership, but each family in one village has the right to cultivate and to crop a number of strips of land scattered over the common fields. From the point of view of the individual cultivator whose land is thus scattered it is more convenient to have his dwelling

1 Meitzen, "Siedelung und Agrarwesen." 
and farm buildings at the centre than adjacent to any one of the tiny parts of his holding. From the point of view of the community it is easier to divide up the land if the fields stretch ont unbroken from the central village than if they are broken here and there by prmanent buildings. And, since the form of settlement is determined by the method of allotting arable land, it may be conchuded that the production of cereals was already important at the time at which the settlement was made. A community, on the other hand, which established permanent settlements, whilst pastoral husbandry was still its chief means of subsistence, would find its line of least resistance in settlement by scattered homesteads. Is Abraham separated from lot because the land wonkl not bear them both, so one new family after another would plant itself forth, and the flocks of the tribe would be scattered in this natural way over the area available without its being necessary at first to delimit precisely the grazing rights of each family. Common ownership of land, however, would disappear more rapidly in settlements of the latter type than in those of the former. As will be seen later, the complicated arrangements of open-field arable culture opposed obstacles to the growth of several ownership which delayed it for centuries. f We have seen that the village nuclens is a product of the openfield system. The origin of this system itself calls for some remark. The problem is to explain why each of the joint users of a certain area of arable land should be given the right to plongh and to crop a large number (perhaps as many as 120) strips scattered all round the compass instead of a single area. Two distinct explanations of this singular arrangement are put forward. First it is described as the result of co-operative ploughing. It is shown that the size of the strips was determined by the quantity of ploughing which a team wouk accomplish in a day. This quantity varied, of course, from one time and place to another. Hence the differences which can still be traced between the areal units (the acres) of different parts of the combtry. It is supposed that a number of men joined their oxen to make up the team, and that the land ploughed each day was assigned in rotation to one of the jointowners and workers of the team. Other writers, whilst accepting the view that the size of the strip or arre was originally determined by the plougling capacity of a team, hold that the land 
was measured off first into strips of this predetermined size which were then distributed in order that each family in the village might have its fair share of good and bad land. Of positive evidence for either view there is rery little. Advocates of the former point to a Welsh law which regulates the distribution of acres ploughed between the joint-owners and workers of a co-operative team. Adrocates of the second advance an instance of the remeasurement and reassignment of acres with the object of equitable redistribution at a date subsequent to the Norman Conquest. It is arguable that the two riews are less incompatible than has been supposed. Mere desire for equity, it is submitted, can hardly have been the origin of division by acre strips, for in innumerable cases the whole of the arable acreage must originally have heen substantially of equal fertility ; where, as often, it was also flat, no insuperable difficulty would be found in dividing it into a small number of sizable plots. But granting that a custom of strip division had arisen out of the practice of cöaration, it is likely enough that it would survive and be retained as a principle of division, even where the land was measured out before ever the plough had traversed it.

The possible survival of a custom developed under more primitive conditions must be borne in mind when we turn to the problem of the origin of serfdom in England. It is sometimes argued that, inasmuch as the open-field system predominated, the mass of the cultivators must originally have been free. It is suggested that no person who was planting more or less servile subordinates on land which he considered his own could have adopted such an inconrenient system. Such a conclusion would be true on the hypothesis that the superior brought an open mind to the business. It is not true if it may be assumed that his own mind and the minds of his subordinates were filled already with a traditional art of land distribution.

The controversy over the extent and thoroughness of the Saxon Conquest in England has been stimulated by the belief that its settlement would throw important light upon the origin of serfdom. Writers who believed that its origin was to be found in a preexistent stage of slavery have argued for a considerable survival of Romano-British organisation, whilst those who held that members of free rillage communities had been gradually degraded have contended for an almost complete displacement of this 
organisation by invading Germans. Recent research seems to show that the problem is not so simple as this.

On the one hand. it is doubtful whether slavery was important outside the towns of Roman Britain. On the other hand, what little is known of primitive German institutions points to the existence of much which we may call. as a neutral term, politico-economic dependence.

Very little is known for certain as to the organisation of production in Roman Britain. Some large estates were worked with slavegangs. especially in the south: but the latifundium was probably not the dominant type. It is more likely that the Romans left matters to work themselves out as seemed good to the native population. preserving law and order and imposing taxation. but not regulating details. It is likely that many of the producers stood in a quasi-servile relationship to some native chief who enjoyed a hereditary right of taxing them. or to some headman who was made responsible for the collection of the imperial taxation. Comparative study of Celtic institutions in Wales at a later date, and of other provinces of the Roman Empire, suggests this conclusion.

The picture of German life which Tacitus drew may or may not be properly admissible as evidence of the institutions and customs of the tribes which. centuries later. conquered Britain. It certainly. contains internal evidence that the artist dwelt affectionately on elements of freedom which attracted him. and treated slightly a substructure of exploited humanity which was too much in the common order of things to interest greatly a classical writer. It would seem that in the intervals of war his Germans feasted, drank, and slept. and occasionally attended political meetings for several days at a time. Such a life is only possible for a class which draws a great part of its supplies from the labours of others-such a class for instance as the Saxon aristocracy of the eleventh century. Nor is it merely a question of a few servile herdsmen. As has been written of the Saxons in England: "their fields of barley will be wide. for their thirst is unquenchable." 1 The few remarks dropped by Tacitus on the slaves of the Germans are instructive. "Each is master of his own house and home. His lord demands from

"Maitland, "1) meslay Buk and Beyond," p. 519. 
him a certain quantity of corn, or cattle, or clothing. This is the limit of his duty." In Germany in the first century, as in medieval England and Europe generally, the "servus" has to give his labour to produce the requirements of his lord, but he retains a life of his own apart-there are limits to his obligations. Here is part of the difference between feudal serfclom and Greco-Roman slavery.

Of the manners and customs of the actual invaders of Britain nothing is known. The very locality from which they came is uncertain. When evidence begins to multiply, some centuries after the Conquest, we find traces of a considerable stock of economic independence and freedom. But traces of various kinds of dependence-where taxation shades imperceptibly into exploitationalso abound. There are important local differences of law and custom. There is everywhere a perceptible survival of British elements. We must prepare ourselves, therefore, to single out the broader types from among innumerable minor differences. The structure of society was moulded gradually by the pressure of a few great forces into a state that medieval law could attempt to systematise, but even in the thirteenth century we shall find that the system is incomplete.

The manorial system, which became the typical social structure in the centuries following on the Norman Conquest, will be discussed in a later chapter. Here it is desirable to search merely for its origins in pre-Norman England. But before this can be done its outlines must be shortly described. The typical manor coincided with an open-field village settlement. The arable land was divided into $(a)$ the demesne of the lord of the manor which was worked by the labour of his tenants under the supervision of a bailiff, and $(b)$ the land of the tenants. The strips assigned to lord and tenants respectively were usually intermingled in the common fields. In addition, the manor contained $(a)$ natural meadow, $(b)$ permanent pasture, $(c)$ waste. Of these the first was often divided into strips assigned to lord or tenants in the same way as the arable. The permanent pasture and waste were common to both parties, although the number $c_{1}^{\text {f }}$ cattle which any individual might maintain on the pasture, and the quantities of timber and firing which he might cut from the waste, were often carefully regulated.

Our view of the extent to which this system had developed in Anglo-Saxon England must be derived somehow from the Domesday 
Inquest. But the problem of interpreting its record is complicated in two ways. First, Domesday is a Norman and not an AngloSaxon document. The Conquest had made changes whose importance can only be conjectured, and the picture drawn of the country was coloured in all probability by Noman riews of what the final settlement ought to be. Secondly; Domesday does not explain itself. It is a collection of statistics grouped under technical headings which were well understood by the men who used then, but elude modern interpretation. For instance, the term "manor" is frequently used, and it is tempting to suppose that the "manors" of Domesday are of the same kind as the "manors" of the thirteenth century. But inquiry shows that this is often not the case. We are left with a dubious conjecture that the Domesday Commissioners used the term to mean a centre for the collection of taxes, though doubtless many such centres were already "manors" in the thirteenth-century sense.

A copy of the actual questions asked by the Cambridgeshire Commissioners has survived, and a collation of the records for Cambridgeshire, and other parts of the country, shows that (as might have been expected) the questions asked in other counties were substantially the same. For our present inquiry the form of the fifth of these questions is significant. The Commission desired to discorer the number of teams plonghing in each taxational district. A simple total was not demanded. The juries were required to distinguish the number of teams $(a)$ on demesile land. (b) on land of the tenants. It may be concluded that at the time of the surver the most usual arrangement all over the country was for the arable land to be divided into (a) land worked in the interest of a superior and (b) land worked by his tenants on their own accomt. The returns corroborate this siew. There were indeed villages where no demesne teams were recorded, but in most cases the division already existed. But, if this is admitted, it is still necessary to ask whether the method of working the demesne by the labour of the tenants also prevailed. It is (lifficult to find in D)omesday positive evidence for this view, though there is certainly none against it. Negatively the returns of population confirm it strongly, for as will be seen later, the number of slaves is so small as comprared with the number of tenants that we are compelled to suppose either that the tenants worked on the demesne or that the work was done by 
a class whose members were not enumerated. The former of these two hypotheses is certainly less objectionable than the latter. It is, moreover, confirmed by all the existing evidence for the centuries before and after the Conquest. As regards the later period, accounts of ecclesiastical estates from the twelfth and early thirteenth century show that the demesne land was worked by the tenants. For the earlier period we have an eleventh-century document relating to estate organisation which reveals the same system already in existence.

The "Rectitudines singularmm personarmm" describes the services due from the several classes of tenants on an estate. Four classes are distinguished. First the Thanes, whose only serious obligations were military service and maintenance of fortresses and bridges. There remain three subordinate classes. The Geneat pays a rent to his lord and performs occasional labour serrices for him-c.g., at hay and corn harrest, or in carring messages. The Cotsetle must work regularly so many days a week. The number varies, but one day a week throughout the year, and three days a week during harvest are given as an example. In addition he must do in general any miscellaneons work that is demanded from him. He pays no rent bevond his labour. His holding ought not to be less than five acres. The Gebur's holding is normally a yardland (ca. 30 acres). He is also provided with stock, implements, and furniture. His labour dues rary greatly from place to place; two or three days a week at different times of the year is an arrangement instanced. In addition he is liable to special calls for labour, and pays rents both of money and kind. It is worth noting that the statement of the Gebur's position occupies twice as mucli space as that of either Geneat or Cotsetle. Evidently the relations between the Gebur and the estate were cardinal to its management. On the one hand his holding was considerable, on the other his labour dues former the backbone of the demesne farming. Further back, at the commencement of the eighth century, the laws of Ine suggest that as the frontiers of Wessex were pushed forward. settlement was effected by granting land to military leaders who planted dependents upon it. Some of these dependents received the yardland, which, according to the "Rectitudines," was the normal holding of the most important class of tenurial labonrers. 
The conclusions suggested so far may be summarised as follows: (1) At the time of the Norman Conquest a system which, on its єconomic side, resembles closely the later manorial system, already existed. On such embryo manors part of the land was worked in the interest of a superior by the labour of tenants who drew their own subsistence from the remainder of the land. (2) There are indications that at least in the later periods of Saxon conquest some part of the resettlement of the country was effected $a b$ initio upon these lines. (3) There existed at the Conquest villages in which all the land was held by the actual cultivators who were not dependent on a lord, but owed only a ciric obligation to pay taxes to the king.

It remains to consider whether in the centuries before the Conquest general conditions had favoured growth or decline in the number of such "free" villages. The answer to this problem is hardly doubtful. In the long struggle between the English and the Danes it is clear $(a)$ that there was a recrudescence of individual freedom in the counties of the Danelaw, $(b)$ that in that part of the country which remained English the tendency was towards serfdom. Among the Danish settlers the element of freedom and economic independence was high. If we follow the Domesday statistics from East to West the percentage of recorded free tenants declines, and the percentages of lower grades of labour and slavery rise. On the Saxon side the pressure of increased taxation and the chances of war brought numbers of rillages into dependence on individual soldiers and small capitalists. In a pre-credit era heavy taxation entails the sale or mortgage of farming stock, and enables an indiridual who has accumulated a small reserve to make what terms he pleases with those who have been less fortunate or farsighted. The destruction of cattle by war would have similar results. Finally, many cultivators would be ready to insure against the danger of total ruin by subordinating themselves and their property to a soldier who gave them hope of protection. In these ways class differentiation increased steadily, and the founclations of a general manorial system were laid. Whether the resultant status of the mass of the cultivators should be called free or servile is a question of more interest to the legal than to the economic historian. Icegally it is probable that until some time after the Conquest the masses were free, although their descendants were called "servi" hy thirteenth-century lawgers. Economic freedom 
however, turns largely upon the right to take one's labour elsewhere, and the resultant power to extract a competitive price for it. But such a right implies openings and opportunities for the transference of labour, and these must have been so rare in Anglo-Saxon England as to leave little room for the dilemma to arise. In one particulary it is almost certain that the masses were not free. According to the "Rectitudines," the stock of the Gebur belninged to his lord, and lapsed to him on the death of the tenant. On the other hand it is probable that they enjoyed security of tenure even against their lord. In the thirteenth century there remained what look like traces of such a right in the privileged position of villains on the royal estates. Here again it must be remembered that no lord would desire to disturb a sitting tenant, unless some alternative use for the land offered itself, and we cannot suppose such cases to have been anything but exceptional.

Now that some conception has been reached of the structure of society in the eleventh century, it is desirable to return to the Domesday Inquest and to try to extract from it some quantitative estimate of the relative importance of the several elements combined in our sketch. In the first place certain classes appear to have a special comnection with the existence of demesne land in a given village, and probably owed labour-service upon it. These (are the villani, of whom 108,000 were emmerated, and the 88,000 bordarii and cottarii. It is at least probable that the majority of the members of these two classes occupied a social position similar to that of the Gebur and Cotsetle respectively whose services are described in the "Rectitudines." Below them (a further class of 26,000 slares was enumerated. The superior classes of sokemen and free tenants together numbered 35,000 .) The impression that sokemen and free tenants represented survivors of a class of independent cultivators, whilst villani, cottarii, bordarii, and slaves testify to the growth of the manorial system, is confirmed by the geographical distribution of the several classes. The free tenants and sokemen were most numerous in the comties of the Danelaw, and of the remainder slaves, bordarii, and cottarii become more numerons as one travels West. But this general statement requires qualification. It is generally agreed that the term villanus did not carry with it in 1086 the degrading associations of its derivative villain in 
the thirteenth century. Most probably the Domesday ". villanus " is a mere translation of the Anglo-Saxon ".tumsman "-the man with a substantial holding in a tún or village. Hence villanus may well have been used of men whose social position differed considerably. It the close of a period of disturbance social distinctions are apt to be less clear cut and decisive than the introducers of law and order would wish. A difference between two men which led commissioners in one district to classify them as villanus and free tenant respectively, might be ignored by commissioners in other parts of the country. In addition, it is distinctly stated in the "Rectitudines" that labour services differ considerably from one tín to another.

The total enmmerated population was nearly 280,000 . It should be noted that the majority of these were heads of families, and that there were considerable omissions-e.g., most of the clergy, the households of great nobles, and some of the largest towns. When allowance is made for these factors. the actual population may be gutessed at between a million and a quarter and a million and a half. The distribution of the population can be stated with more confidence. Lincoln, Norfolk, Suffolk, and Essex have between them just under one-third of the total enumerated-ca. 89,000. Kent, Sussex, and Hants have 33,000, Somerset, Devon, and Wilts 41,000 . These ten counties had 163,000 of the total 283,000 . The rest of the country had 120,000 . There is reason to suppose that the figures for East Anglia are slightly exaggerated: on the other hand Hidtlesex would probably appear among the populous counties but for the omission of London; and the omission of Winchester must have affected appreciably the figures for Hants. Finally, in arguing back from, these figures to AngloSaxon conditions, the harrying of the North between the Conquest and Domestay must be remembered.

The questions asked by the commissioners contain much that is suggestive of the economic organisation of the country generally. It the present time orer a great part of the country there is little cereal cultiration, and since the sixtcenth century there has been much localisation of cereal and pastoral husbandry respectively on land naturally adapted to each. The Domesday Commissioners, on the other hand expect to find in each village $(a)$ plough land to produce cercals, (b) meadow and pasture for stock, $(c)$ wood to 
provide material and fuel. The presence everywhere of the same kinds of production suggests the absence of exchange, and there is much contributory eviclence to show that each rillage was almost self-sufficing. Cereal cultivation was the centre and dominant part . of the system. Meadow and pasture provided feed for milch cattle, sheep, and poultry, but they were above all required to feed the oxen which drew the plough. No doubt the proportion of cereals to meat and dairy products in the food of the peopte varied: but the variations, so far as can be judged, were small. If the population in each county is divided by the number of teams, the result is an approximate statement of the number of heads of families per team. The lowest is $2 \cdot 1 \mathrm{in}$ Hereford, the highest $5 \cdot 5$ in Norfotk, and of the thirty counties for which the calculation has been made, in only thirteen is the figure less than 3 or more than 4 . It is impossible to estimate precisely the acreage actually under the plough, but, as compared with the population, it was evidently very large. An acre yielded, however, in all probability hardly one-eighth of the average yield of to-day.

The self-sufficing character of the Anglo-Saxon village may be illustrated from a statement on the cluties of the reeve, or bailiff, which is attributed to the first half of the eleventh century. The work proper for the four seasons is described as follows-

"In May and June and July, in summer, one may harrow, carry" out manure, set up sheep-hurdles, shear sheep, build up, repair, hedge, build with timber, cut wood, weed, make folds, and construct a fish-weir and a mill.

"In harvest, one may reap, but in Angust and September and October one may mow, set woad with a dibble, gather home many crops, thatch them and cover them over, and cleanse the folds, prepare cattle-sheds and also shelters ere too severe a winter come to the farm; and also diligently prepare the soil.

"In winter, one should plough, and in severe frosts cleave timber. make an orchard, and do many affairs indoors; thresh, cleave wood, put the cattle in stalls, and the swine in pig-sties, set up a stove on the threshing-floor-for an oven and a kiln and many things are necessary on a farm-and moreover (provide) a hen-roost.

"In spring, one should plough and graft, sow beans, set a rineyard, make ditches, hew wood for a wild-deer fence ; and soon after that, if the weather permit, set madder, sow linseed (i.e. flax seed) 
and also woad-seed, plant a garden, and (do) many things which I cannot fully enmmerate, that a good steward ought to provide. "He can always find something on the manor to improve; he need not be idle, when he is in it; he can keep the house in order, set it to rights and clean it; and set hedges along the drains, mend the breaches in the dikes, repair the hedges, root up weeds, lay planks between the houses, make tables and benches, provide horse-stalls, scour the floor; or let him think of something that may be useful." 1

Then follow long lists of implements, tools, and utensils, most of which then and long afterwards were made locally in each rillage or small group of rillages by millwright, carpenter, or smith. The list of tools for working up the wool and flax of the village is interesting-spindle, reel, yarn-winder, stoddle, weaver's beams, press, comb, carding-tool, wool-comb, roller, shuttle, and others.

Communities of this kind can have had little trade with one another, or with the outside world. Salt and iron were necessaries of existence, and must in most cases have been brought from a distance. The country as a whole had an appreciable export trade in wool and a few other raw materials. The circulation of money, in so far as it existed, was probably due to the expenditure of the wealthy and their personal retainers. The Anglo-Saxon law of property is largely concemed with cattle-stealing. A man lay under suspicion of theft if he bonght anywhere but in town market before witnesses. There may have been buring and selling between members of the same village, but in many cases the specialised artisans seem to have been paid a fixed salary in kind either by the lord or the community in return for their labour. There are, however, indications of an increase in exchange in the last two centuries of the Saxon periol. It is believed that the use of money increased rapidly from the early part of the ninth century, and the attempt to generalise the use of standard weights and measures throughout the country can be traced back before the Conquest. f For this revelopment the Danes were partly responsible. Their influence on london can be traced in survivals at a much later period. They bronght the country into close relations with Scandinavia, and infused a spirit of adventure, half commercial, half predatory, which the Saxons lacked or had lost. Other influences

1 From translation in Cumningham, "Growth of English Industry and Commerce," * 1). 574 . 
which worked in the same direction were those of Rome and France. Contact with the higher civilisations of the Continent aroused neels among the wealthy classes which could not be met by pork and beer produced at home. In the time of Charlemagne protection was exchanged for English merchants on the Continent and Frankish merchants in England. In the reign of the Confessor there was a great increase of intercourse. The beginnings of a trade policy are discoverable in the fixing of a minimum price at which wool might be sold for export: regulations have survived which prohibited foreign merchants from selling retail or displacing English labour in other ways. Special arrangements had been made with the Rouen wine merchants. The men of the Emperor had been privileged to maintain a depôt in London.

Of the boroughs enumerated in Domesday many were still hardly more than large agricultural villages, differentiated from those around them by strategic and political importance rather than by economic specialisation. It is probable that even such important centres as London and Winchester were commercial rather than industrial, and that their specialised craftsmen, so far as there were any. were producing for a local demand of the wealthy. and not for export throughout the country. The growth of the towns was due apparently to many distinct causes, several of which may have co-operated in any particular case. Sometimes the beginning was a local market, sometimes a fort, sometimes a monastery, sometimes a convenient landing place on the coast or on a tidal river. Differentiation of the burgess' status from that of the cultivating masses had already made some progress, though the boroughs still retained their common fielels, and though in many cases agriculture was still the chief work of most of their inhabitants. Trade postulates the enforcement of at least a minimum of commercial morality together with more accurate definition of the rights of political superiors than is necessary in an unprogressive village. Thus we find first a superior peace maintained in the town markets which insured the property of one nerchant or burgess against the attacks of his fellows, and second, a limit to the fines which might be exacted by lord from burgess which checked oppression and stimulated the accumulation of wealth. It is uncertain whether any trading or industrial corporations analogous to the merchant and craft gilds of later tines had yet come 
into being. Gilds for religious and eleemostnary purposes were already common. but the earliest evidence of a gild merchant is subsequent to the Conquest. The spirit of association. however. which manifested itself in later centuries is not produced by trade w? industrial specialisation: it arises inevitably where a number of men have a common interest in protecting themselves against general dangers or the might of an individual superior. It existed on the medieval manor no less than in the medieral town, though it inevitably expressed itself differently in the two cases. 


\section{BOOK I \\ MEDIEVAL, ENGLAND \\ $1066-1272$}




\section{CHAPTER I}

GENERAL STRVEY

ADAM SMITH ascribes the origin of division of labour to " a certain propensity in human nature . . to truck, barter and exchange one thing for another." He analyses the effects which this propensity will produce in a society whose wants and means of satisfaction are simple. His object is to expose the working of economic motive beneath the surface of society, and he is not concerned to discuss in detail the obstruction which other motives offer to its smooth working. In studying the economic history of a country, interplay between the economic and other motives must be kept constantly in view. The propensity to truck and barter competes with equally natural propensities to murder, steal, enslave, and cheat. Predominance of the cruder manifestations of these motives in a primitive society lengthens and makes tortuous the process of developing exchange. One of the chief interests of economic history is to watch the turns and twists of society in its efforts to establish an environment favourable to commercial morality. The most complicated civilisations so far established show no sign of escaping from the labyrinth. On the one hand, enormous expenditure is incurred with the intention of limiting crude violence and fraud; on the other, the development of more subtle forms of oppression and exploitation runs a close race with expanding social control.

Modern society is hased upon elaborate legal definitions of ${ }_{\tilde{m}}^{3}$ rights and duties, which are guaranteed by conservative institutions, and can call to aid on occasion the massed forces of prejuclice. In many directions the individual is released from taking thought for his own security, and as the law, where possible, prefers restriction to specific commands, there is room for almost infinite differentiation between the manner of life of individuals. In medieval England. the individual was less protected. Legal procedure was even 
more defective than it is now. The law was too chunsy an instrument to control any but the crudest forms of ill-doing. and if it is still difficult for the poor to enforce it against the rich, it was infinitely hareler then. As a result, exploitation was more direct and lorutal than it is at present, though perhaps not relatively greater in amount. Hence the importance of association in all departments of life, together with the enforcement by custom or law of a detailed scheme of life upon each large class in the community. The individual's best chance of preserving a tolerable existence against the encroachment of armed force lay in defining his duties towards his political superiors identically with many other individuals in order that formidable numbers might feel a direct and personal interest in protecting him. That society could, as a whole, have an interest in enforcing goneral rights and liberties, such as the right of contract, was only dimly perceived. A more immediate and tangible appeal was provided by the principle of association, which, whether growing unconsciously from the soil of conservative tradition, or embodied in a formal institution, drew together the members of a class or the inhabitants of a district to formulate and maintain collectively their common standard of life. The tendency is evident in erery rank of society. On the manor the cultivators were grouped in a small number of classes, each with carefully defined duties, the same, or nearly the same, for each nember of the class: the equality of town burgesses had essentially the same chararter: and in a similar way the upper orders fell into classes, each one of which songht to define accurately its relations and (luties to all other classes, and the King over all.

On the other hand. the tendency of inferiors to group themselves in orters which offered a resistance to oppression, either active as in the case of the burgesses, or jassive as in the case of the serfs, was mot and cmonuraged ly a parallel temeney for superiors to fromote such gromping for greatre facility of government. A weak king foumd security for his power loy insisting upon adlerence to arrangements whicle custom had sanctioned: a strong king condel lest organise socicty, and in particular best prevent such inter-class oppression and olfucial exaction as reacted on his own position injurionsly he favouring the growth of a sorial lackler, cath rank of which hat dearly-defined duties and privileges. What wa's true of the ling was true of the landowner. In the long run 
the manorial system was managed more casily by the lord who accepted a clear definition of tenurial duties than by one who maintained the practice of individual oppression.

Analogous influences may still be seen at work; a parallel, which is full of interest, may be drawn between modern factory industries and the medieval manor. The economic position of an employer, with hundreds of men in his pay, gives him a strategic advantage as a single purchaser of labour confronting competing sellers. Hence the trade union which combines a large number of workers for resistance to individual oppression and enforcement of precisely defined rates of remuneration and conditions of work. On the other hand, it is a necessity of large-scale busmess, even from the employer's point of view, that the workers should be graded in ranks, and that the terms of employment should be ilentical for all members of a particular grade. But the difference between the modern factory and the medieval manor is as significant as the analogy. The strength of the employer lies merely in his greater bargaining power as compared with any single employee. He cannot enforce physically conditions which are unacceptable: the pressure which he can bring to bear is limited by the right of the employee to take his labour to another market; and in trade union he meets a bargaining power which may be equal or even superior to his own. On a medieval manor, association of tenants or employees for collective bargaining was hardly practicable: they were too much subjects of their lords for a contractual relationship to subsist between the two parties. All that the inferior class conld hope was to establish their standard of life on the rock of tradition and trust to conservative sentiment for its preservation. It is not of course suggested that the course of events was directed by much conscious perception, whether among serfs or lords, of the limits of social equilibrium. Such insight is even today only rarely found amongst those who are directly interested on one side or the other in wage bargains. The growth of medieval status was a long process of ahmost unconscious evolution. Social arrangements which did not fulfil the minimum requisites of stability died out gradually. The reverence for class standards of life, which eventually gained control over the minds of the majority, originated in conservative affection for a system which had grown 
to be the basis of society. It was not deduced by a social philosophy inquiring how man in the abstract combl reach ideal ends.

The conditions farourable to the growth of status were gradually weakened by immer goremment and more elaborate law. But long after ther had ceased to ba dommant amongst the forces which were monlding societs. the ideal which had grown out of them interfered to protect from decay the institutions which they has fosterel. The forees which promote indridual independence became important as early as the thirteenth centurs, and assumed the upper hand in the sixteenth century: but the social ideals, which are the natmal product of these forces, clid not become important until the second half of the eighteenth century, and are even set imperfectly developed. The complications of historical derelopment which result from the survival of ideas after the comlitions which bred them have passed away are important. Before the Xoman Conquest the demand of a wealthy class mack necsiry a certain measure of urban concentration at a time when the mass of the nation was still organised in selfsufficing village communities and when no general security for indiviclual life or property existed. These conditions of urban differentiation remained preponderant over all others long after the cinquest. The persistent effort of the royal government was gratually , tereloping the conditions which ultimately made lonsible an extensive division of labour: but the earlier traters ancl craftsmen formed perforce a special class. Their relations with their political smperiors were defined carefully, so as to give them the minimm of semity necsary. Thus the towns grew up in atn atmo-pluere of privilege and association. I.iberty to the lomerses meant not merely the begally-protected right to do crtain things which is its essence te-tast it contained, also, an element of superiority to othere people. Thus the modern concoptions of liberty and privilege were interfused, and the habit of thenglat porbued in this way ontlasted the need for privileges. and contributert to shape the reoruanisation of society which

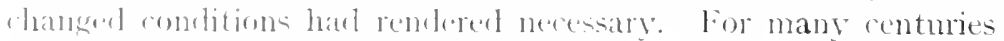

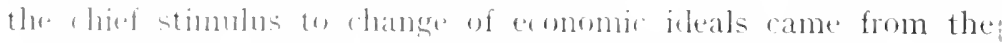
rusal dintriets. Coban trate and homdicraft had their roots in prisilege, and diet litte to throw off its antrol till they were renomstrueted by the Industrial Revolution. The agricultural 
pystem which grew ont of the decay of the manor was not the product of privilege; it sprang up spontaneously from the improvement of law, the tightened grip of the executive, which made it possible for the individual to stand alone. Since the Industrial Revolution the country has becn conservative, the towns have faroured change. The reason is not that animals move more slowly than machinery, but that urban chaos is younger than rural society. The converse proposition is true of the close of the Niddle Ages. An urban system existed, decadent but strong, to resist and regulate imnovation. In the country was the chaos-the pushings of new life which produced the social system of eighteenth century England.

The most casual glance at the history of medieval England reveals the fundamental importance of land tenure at that time. The amount of land held by an individual and the terms on which it was held were anong the chief indications of his status. The part played in the production of wealth by organising ability was far smaller than it has since then become, and hence the riglst to tax thel labour of others was almost the only way in which a large income could be obtained; but the labour which produced wealth was seldom far removed from field or pasture. The majority even of craftsmen and traders had only partially specialiser their occupations, and still drew part of their subsistence from agricultural holdings. It resulted inevitably that wealth implied land and land wealth. I The landlord wielded power: the powerful translated their influence into lordship over land. The class organisation which arose from these conditions was economic in one aspect, in another it was political. It is better, however, to call it simply "feudal." Strictly speaking, neither the economic nor the political relation between one man and another yet existed. There was a single relation which possessed some elements of the cash nexus, some features of sovereignty. It cannot, however, be described satisfactorily by any enumeration of modern conceptions: it is best described by a separate technical term. To illustrate the difficulty of discussing the economic history of medi val England in terms of modern life we may take a problem arising out of the manorial system. Later it will be necessary to consider the process by which landlord and tenant reached agreement as to the service and payments which each class of tenants owed his lord. It is 
convenient to speak of labour, produce, and money "rents" in this connection. The word, however, if used, must be used with care. It is not merely that we find in the rents paid on the manor elements alien from the rent of modem economic analysis. That rent is equally an indefinite proportion only of the rent of a modern farm. But whereas with us rent has primarily a business sense, and denotes a payment freely offered for the use of certain income-rielding assets, payments for land under the manorial system had a political tinge. We must combine with conceptions derived trom modern business ideas derived from modern taxation, in order to improve our picture: and since the income derived by lord from tenant was exacted from the weak by the strong, and was not a contractual price for the maintenance of law and order, we must add to the picture an element of exploitation. The peasant existed to contribute towards the maintenance of his lord. The one was subject, the other sovereign. In defining the amount of this contribution the considerations present to the minds of the parties were no doubt partly economic. The root question, however, was not, how much is this particular holding, worth: hut how much ouglit a man of this particular status to contribute to the necessities of lis lord?

The begimnings of English feudalism go back to the Saxon invasion, but a rapid development took place as a result of the Norman Conquest. The importance of the land nexus is strikingly illustrated by details in the settlement. The invaders could exploit their victory only by displacing English landlords and by increasing tenurial burclens. Twenty years after the Conquest less than one per cent. of the land of the country remained in the hands of those who had been its lords on the day when Edward the Confessor lived and died. The English nobility were dispersed. The men crowded into the military service of European courts, the women fled to mmeries or becanc the wives or mistresses of the invaders. This displacement of the native aristocracy was one part of the indemnity exarterl from the subject nation. There is eridence also of great degradation of the producing masses. The architectural activity of the first half-century of Norman rule is one indication that the distribution of wealth was displaced to the advantage of the ruling class. It is known that forced labour was employed on castlebuilding. The legal profession which arose under shelter of the 
administrative genius of the Norman dynasty retained a tradition that the masses had fallen in the social scale. Where the Domesday record perinits comparison between the state of the peasants in 1066 and 1086 respectively, it appears that both economic and social degradation resulted from the coming of foreign masters. The immigrants were not exclusively members of the governing classs, though for a consiclerable time the legal position of a "Frenchman" was ipso facto superior to that of most Saxons. Both King and nobles settled upon their new estates, and in their strong places the rank and file of the arny, and it is probable that gifts of land rewarded those who had provided transport and commissariat for the invasion. Numbers of traders and artisans came over from the continent. The new buillings were at least in part the work of Noman masons. Nerchants followed their clientele from Rouen to London, and the strong French element which can be traced in many towns for some centuries after the Conquest was doubtless due in part to traders and craftsmen who followed their lords from home.

Exploitation was the immediate and most obvious result of the Conquest. Other results, however. which were ultimately more important, soon came in to view. Before the Conquest, incipient feudalism in England showed the centrifugal character which marked its action elsewhere; the Conquest brought an ansirer to the question whether England should be a congeries of provinces or a nation., Partly as a result of the slow amalgamation between the two races, which gave to the governing class a common interest lacking elsewhere, partly in consequence of the ability of the Conqueror and his successors, a centralised system of law and administration was early constructed. The developing industry of the country was comparatively little concerned with those local differences of law and government which remained important in France until the Revolution, in Germany until forty years ago. It is convenient to emphasise here the relative freedom of English development from local restrictions and jealousies, for, as has been seen, the general conditions of medieval Europe were such that new elements of social life required the shelter of privilege and exceptional treatment. We shall have constant occasion to notice this fact. and few opportunities, comparatively, for remarking that it was of less importance and disappeared sooner in England than elsewhere. 
The history of English law traces through the reigns of the Norman and Angerin kings an almost continuous growth in the scope and firmmess of roval justice. The powers of manorial courts produced less local variation than might be expected. The estates of great nobles were scattered over many comties, and a considerable measure of common practice was achieved. Close relations were maintained informally between the courts of the Crown and of the Church by the practice of making bishops administrators and administrators bishops. The royal judges were ready to consider and on occasion dispute the competence of ecclesiastical and feudal courts. Contemporaries saw clearly the relation between firm administration and prosperity. National progress, perhaps, is an idea that conld hardly suggest itself to a medieval writer, since political conditions and religions belief combined to preclude speculation over the future: but the historians of the period were interested in the inmediate import of economic erents. They noted the bad results of disorder and of fraud on the coinage; they praised the men who "made peace for men and deer," in whose time " a man could fare through the land with his bosom full of gold." The colossal difference between the government of Stephen, or even William II, and that of William I or Henry I, still more of Houry II, must have left little room for thought whether subtler economic causes were making for progress or decay.

1 further important contribution to economic progress was the Noman habit of methodical administration. The govermment of the country gained in precision and consistency by the accumulation of recorts and surveys Domesday Book, the financial records in the cireat Roll of the l'ipe, and the legal records which go back to the cond of the twelfth century, are evilence of a growing tradition of control and foresight. Nor was the taste for method and aremacy peculiat to the crown. Sorlem knowledge of the manorial system is derived from accomts and survers of estates drawn up for the great landlords, lay and ceclesiastic, and from manoriat controbls, as well as from the papers of the central government. The manorial statements presuplose that less claborate accounts of daily income and expenditure were kept habitually by the bailifs, at least in the latter part of the thirternth entury. Direct connection between the Nomang genins for alministration and the development of linglish indestry can seldom be proved, but a few words 
may be added on this topic. Soon after the Conquest the chronicles notice isolated cases of great landowners who improved their property, and at the same time promoted the prosperity of their tenants in the manner of Coke of Holkham seren centuries later. A recent historian of the period gives the following general impression: "It may be that in these men we have rare exceptions, and that they were only praised by comparison with a prevailing ruffianism. But we have good reason for thinking that what har been the exception in the first became the rule in the second generation of the Anglo-Norman baronage. In the days of Rufus and of Henry I power passed to the hands of men like Richard of Rulos, the knight who is remembered in the traditions of Crowland for liberal benefactions, the draining of the Depedene fen, and the foundation of new villages where previously there had been wastes tenanted only by the water-fowl." 1 Great religious houses were also pioneers of improved agriculture and settlement in backward districts. In particular the export trade in wool was largely developed by the Church. And although the Normans had their full share of gentlemanly contempt for huckstering trate, both great nobles and great ecclesiastics were ready to conduct commercial operations on a large scale. From the thirteenth century onwards cadets of noble houses are even found engaging in urban trate, and combining with rising merchants and craftsmen to form a new middle class.

Another sphere of influence is opened up when the Normans are regarded as renewing the connection with the Continent of Europe, which had been broken by the withdrawal of the Roman power. The effects were important, both on (action and on thought.

Under the first head should be noticed the commercial intercourse which resulted inmediately from the dynastic links between the new monarchy and the Continent. An early instance is the increase of trade with the Netherlands, due to the Flemish extraction of the Conqueror's wife. Nore important was the fact that for several centuries the King of England was lord of French provinces. Again the adventurous spirit of the Normans and their close relations with European chivalry gave England its share in the Crusades, and in the increased trade between the Mediterranean

${ }^{1}$ H. W. C. Davis, "England under the Normans and Angevins," p. 41. 
and Europe generally which arose out of them. Besides stimulating trade, the Crusades hastened the transition from producerents to moner-rents, gave many towns the opportunity to buy more freedom from their lords, and necessitated large credit operations to effect the advance and transmission of funds.

The influence of Europe on English thought was chiefly /effected throngh the Church. The English clergy, under their new superiors, quickly improved in tone and eclucation, and the change was renewed from time to time by fresh draughts on Continental sonrces. Hence the rise of trade during the twelfth and thirteenth centuries in England went on side by side with a developing commercial ethic which was common to the whole of Westem Europe. It is indeed easy to exaggerate the importance of European influence as regards the foundations of this moraity. The common stock of Christianity combining with conditions very similar to those prevailing on the Continent would doubtless have produced parallel though independent developments. And in fact the beginnings of the later development are tracable before the Conquest. But the closer connection after that date produced an identity of detail which makes it possible to interpret English thought by books that were the common property of Europe.

The ascetic tendency which has always been immanent in Christianity led men to despise wealth, and to admire poverty. The result in practice was paradoxical. On the one hand, charity was commended with little thought of its possibly degrading influence; on the other, medual distribution of wealth was not very seriously resented, sincerich and poor were equal in the sight of God. Yet although the fact of degrees of wealth wats tolerated by the Church, actions which tended to create it were condemned if even a suspicion of rovetomsness attarhed to them. The pursuit of wealth for its $\checkmark$ own salie was regarded as definitely sinful. But the pursuit of wealth dirl not mean to the medieval mind what it means to the modern. Alorken analysis inchules within the term weath everything that satisfies desire, aml hats exchange value, and sometimes eren omits the second half of the definition. Every consumer, accoreling to om ideats, comsumes weatth. Even if he does not carn (mongh to buy adefuate momishment, we think of him not as entirely devoicl of wealth, hut as having too little for that particnlar purpose. Sot in current speech even now we hardly remain 
true to our intellectual conrictions on the subject. A wealthy man means to us not merely one who has more wealth than others or than the majority. It implies usually one who has a surplus, more than enough. that is. to provide for the standard of life which seems his due. To medieval thought wealth began with the beginning of such a surplus, and generally in distinguishing between wealth and poverty more attention was paid to net than to total income. An attempt to increase the surplus, to heap up riches, was condenned, unless the surplus were accumulated with some definitely good onject in view-the relief of the poor, the service of the State or Church. These views were a natural product of the conditions of the time and of ascetic ideals. Opportunities for investment and for culture were so limited that a disproportionate share of surplus accumulations was inevitably either spent on more 2 elaborate food, clothes, plate, and jewellery, or heaped up in treasure of money and bullion. Even if the surplus was used productively to increase its owner's income, such increase could only be used in the manner indicated or in providing additional personal attendants. If it is true to-day that the rich find it easier to increase the mere quantity of their consumption than to increase its variety and quality, it was infinitely more true then. This conception of weatth as a surplus fund outside and independent of what was annually produced and consumed, and of the land and implements used in production, lay at the root of the identification of wealth with money which long impeded the progress of economic science. Starting from the belief that the effort to create an idle or luxurious surplus was sinful, medieval thought developed a logical doctrine of the just reward of labour and of the equities of exchange. A man did wrong who secured a surplus, still more wrong if in securing his own surplus he made the income of another deficient. The point, however, at which a surplus commenced for any individuai was not defined on a subjective view of the reasonable needs of a civilised being, but empirically from the customary standard of life obtaining in the class to which that individual belonged. Briefly it was held that the class standard of expenditure gave a satisfactory criterion for fixing rents, wages, and prices, and that those who attempted to raise or to lower it were guilty of covetousness or oppression.

It is sometimes suggested that whilst competitive adjustment 
of standards is normally detrimental to the masses, medieval regulation framed on the doctrine of just price normally protected them. The fact seems to be that either system would work sometimes for and sometimes against the interests of any given class. The persistent attempts of the English Government after the Black Death to check the rise of agricultural wages and to prevent other adjustments farourable to the workers, which competition was tending to produce, were quite in accord with contemporary ideas of economic justice. One class seemed to be and indeed was using a national disaster to extract better terms from another. The Government might have made out a good contemporary Christian case for its behaviour. In other cases, of course, the doctrine had a tendency to protect the weaker party, especially against the effect of temporary fluctuations in the demand for labour, which by lowering wages temporarily might have lowered efficiency permanently. It is evidently impossible to determine whether the good or evil effects of the theory were more important.

The doctrine of just price was shaped grarlually to meet the practical problems which arose out of the gradual increase of trade. The relation between lord and tenant on a manor was controlled by customs, and could be explained by the doctrine once it was formulaterl. On the manor however, the very supremacy of custom woukd prevent formula, for the doubt ful question which the formula was reguired to answer would not arise. In trade, on the other hand, men made profits or losses, and often in a market so restricted that there conkl be no cutestion of free competitive price. The rate at which exhange woukl take place might fall anywhere between points consirferably apart, in the absence of an ethical criterion to derirle what price was fair to both parties. Aquinas, who smmmed up (hristian opinion in the mirldle of the thirtenth century, restricted his discossion to trade, for the wage systeni was still only slightly developed, the craftsman was usually also the salesman, and $j$ the efuity of rents moukl fall within the scope of political rather

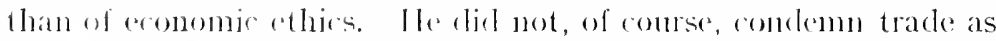
surh. (on the contrary la legarted the tarler as a valuable social

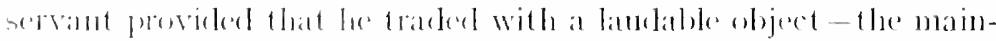

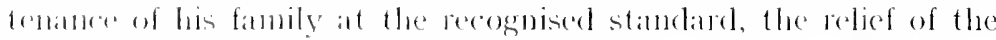
pors, or the bemetit of his combly. He would, however, have 
been impatient with the modern reasoning which proves that great social benefit may arise out of speculative operations which are in themselves little better than gambling when they do not involve in addition deliberate fraud. In the Middle Ages the purchase of goods with the object of selling them in the same market at an enhanced price was universally condemned, and there is no reason to doubt that this condemnation extended to some operations which cannot be distinguished theoretically from the useful carrying of stock performed by the ordinary retailer. But, inasmuch as the services performed by the retailer were well understood, it may be assumed that "forestalling " and "regrating " involved in most cases such attempts to corner the market as are disliked to-day by many who strongly deprecate legal intervention. The most usual case was that in which one of a number of retailers bought up available supplies of the commodity dealt in and used his monopoly to squeeze either other retailers or the general public. The attempt to check this practice may sometimes have postponerl the development of a really useful midkleman-class between producers and retailers. There were, however, very few towns in medieval England where business was done on such a scale that the retailers could profitably break off direct relations with those who brought in commodities from the outside world.

The medieval mind had great difficulty in applying the loctrine of just price to the particular case of hire of money. The acceptance of a price for a loan, when full security for return of the money was given, was called usury. It was condemned by religion, and usually forbidden to Christians by the State or municipality. The Jews, inteed, from the Conquest until their expulsion, were not only allowed to extort usury, but were protected and encouraged in so doing by the Crown, which found in their delinquency a profitable source of revenue. It appears, however, that the loans of the Jews were principally advances to the State and for the personal expenditure of the wealthy classes, and the same is tme of their successors, the Italian and Flemish bankers. There is no direct evidence that the Jews commonly supplied the current needs of trade and industry, and indeed there is negative evidence against such a view. since it woukl seem that at a much later date most men tratcel chiefly on their own capital. During the first three centuries after the Conquest there were few opportunities for such rapid extensions 
fof business as call for the use of horrowed capital. The money required was gathered gradually as the business grew. Consequently the need of a loan usually implied some great disaster which had destroyed all or part of an individual's stock. Similarly in primitive farming all over the world to-day the usurer makes his profit out of other people's misfortunes. The fact that the borrower was usually hard pressed might, however, have been met by a simple application of the doctrine of just price had it not been supposed that money was barren, and that consequently he who received back any price at all in addition to the capital had exploited his debtor. The theory that money is barren seemed to be proved by the simple fact that money, when left by itself in a chest, does not increase, ant if we assume that the lender in most cases would not have employed otherwise the money which he lent-would in fact have left it in his strong box-the rule that no charge should be made where no risk was incurred becomes at least intelligible. Evidently in a pre credit period the average trader was bound to accumulate certain funds to meet the larger disbursements which his business occasionally required. If a man borrowed some of the money with ample secmity for its returm before the date at which it would be needed, it was literally true that the money which he took would have been barren during that period if he had not taken it. That the transaction wals often of this nature becones clear when we consider the gradual development which brought men to a general atmission of the equity of interest. We find it first admitted by the doctrine of dammum emergens that if the money was not returnerl at the date stipulated, and if in consequence loss fell upon the lender, a charge commensurate with the loss might be made. A little later came the doctrine of lucrum cessans which permitted interest to be claimed when the money was not returned, not merely in cases where dired loss hat been cutailed on the lender, but also if he hard been prevented loy lack of funds from doing profitable business. 

Suggestion of village with three fields divided into furlongs and acres the 30 black acres represcnt one virgate.

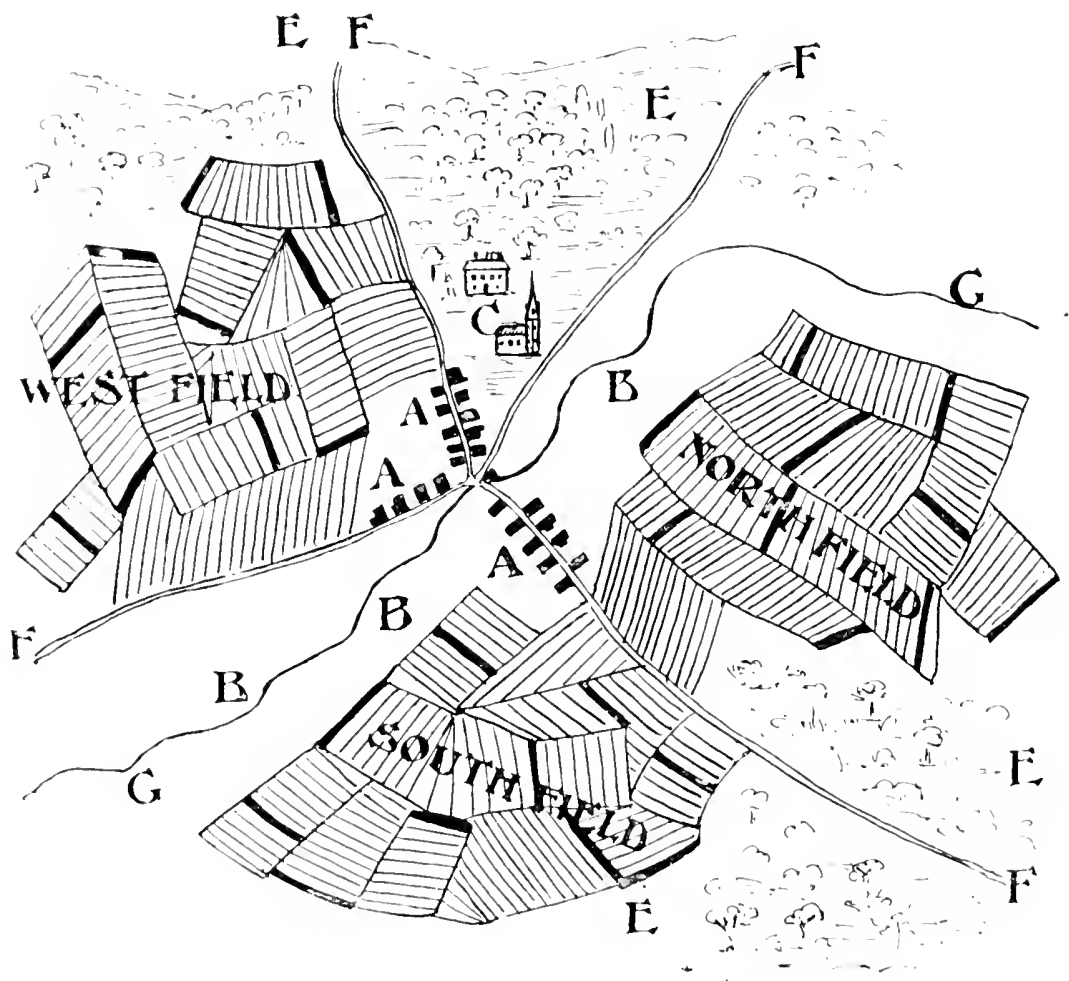

1. 1. Tenants' meisuase,

l: l: Wood and rough pasture

13. 13. Satural meadow

li li. Roals

(.) llall and church

(; ) : Siream 


\title{
CHAPTER II
}

\author{
THE MANORIAL SYSTEM
}

THE beginnings of the manorial system have heen described already. In 1086 the Domesday Commissioners made the distinction between "demesne" and "tenants" "ploughs part of the basis of their investigation throughout the country. An increasing wealth of material during the next three hundred years compels the conclusion that in the thirteenth century the manor was the predominant form of agricultural organisation over great part of the country. It is clear also that the tendency was for variations to disappear and one general type of manor to establish itself. The purpose of this chapter is to examine that type, though it will be necessary to remember that infinite minor modifications of it continued to exist. We have spoken of "agricultural" organisation: "economic" would be more accurate; for the manor remained almost entirely selfsufficing, as had been the communities out of which it had arisen. Housing, fuel, clothes, utensils, implements, tools, furniture, were made by local labour of local products. The arable fields were tilled with oxen whose feed came partly from these fields, partly from permanent pasture and natural meadow land. There was waste and wood which provided fuel and the timber needed for building and other purposes. The wool and the leather required were produced and manufactured on the spot. It is easier to enumerate what was not made than what was made locally,-iron or other metals, salt, and tar to treat sheep against the scab, were the only staple imports.

The manor most often coincided with an open-field village. At its centre two or more roads usually intersected, near to or crossing a strean. Close to their meeting point stood the Church and the Hall. Along the roads were arranged the dwellings and farm buildings of the tenants, each in its separate close, divided from neighbours and road by a quickset hedge. The Hall hatl, in most cases, several enclosed fields near it. From the village the arable 
open fields spread ont in all directions-except that the natural meadow by the stream was reserved. Beyond the arable were permanent pasture, waste, and wood. The arable was worked either on the two-field or on the three-field system-the latter being most common. Very occasionally more complicated arrangenents are found. In the two-field system, alternately each year, half the land was ploughed up, the other half lay fallow. In the three-field system one-third only lay fallow, the remainder was divided into two fields; on one wheat or rye, on the other oats or barley were sown. the fields whilst under cultivation were enclosed with hurdles. When they lay fallow, and between harvest and ploughing, the cattle from the permanent pasture wandered over them freely. The reapers using sickles left a stubble twelve or eighteen inches high ; the percentage of more or less edible weeds among the crops was large; thus the unemployed arable added considerably to the arailable feed and was manured antomatically. The fields were divided for crops as follows: a number of "furlongs" or "shots" were marked out, each some 220 yards in willth and as long as the nature of the ground permitted. These furlongs were further cut up into acre or half-acre strips whose length was the width of one furlong and breadth a chain or half a chain (22 or 11 yards). Between each strip the natural turf was left for demarcation. These divisions, which often had bushes or trees growing on them, were called balks. The furlongs were divided from one another by " headlands," the spaces on which the ploughs were turned. ${ }^{1}$ The acres or half-acres were distributed to the lord and certain classes of the tenants. As a general rule no two arljarent strips were worked by the same man. The natural water-meatow was sometimes held severally by the lord who let off parts of it to his tenants; but often it was divided into equal strips by hurdles when the grass began to grow, and divided up by lot among the tenants until the hay was gathered. After hay harest it was thrown like the fallow into the general pasture of the manor. The pasture was used in common by the

1 the divisin of thr land was of course inevitably rongher than a bare description of type can sluw. The tentency was to carve ont paralleloframs as descrilede But the slatge of the gromed resisted the tendency.

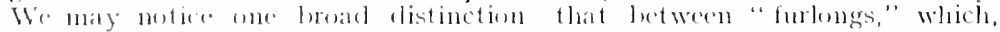
leswever crublely, purported to be rectangulat, and the triangular corner jatches which were kmewn as "gines." 
lord and the tenants-custom limiting the number of beasts that any one person might leep on it. The wood and waste land was used similarly by the swine of all members of the commumity in common, and all parties had certain rights to cut timber and fuel. At least by the thirteenth century, in addition to the enclosed fields about the Hall and the closes on which stood the dwellings and farm buildings, a number of enclosures had come into existence which were rented from the lorel by individual tenants on special terms.

The lord's enclosures and the strips held by him in the common fields were known collectively as the demesne. They were worked on under supervision of a bailiff, partly by paid labourers. principally by tenants who owed service for their holdings. The relative positions of the several classes of tenants can be most easily defined in reference to the work done by the members of each class on the demesne. We find in the first place a deep gulf fixed by law and opinion between free and villain tenure-the ancestors respectively of free socage and copyhold. This gulf, however was not so clearly marked in the economic organisation of the manor. The one class shades into the other from the point of view of the economist, a fact which so far reacted on legal status that it taxed the ingenuity of thirteenth-century courts to decide in certain cases whether the services by which a particular man held were free or villain. The clearest cases of free tenure were those in which no labour rent was due and no fines payable on marriage of daughter or placing out of son. In general a man who paid a determinate rent in money or kind was free: nor did he become villain in consequence of owing labour service if both quantity and quality of such service were clearly defined. On the other hand, a man was a villain if he owed a considerable and indeterminate labour rent. The mere definition of the number of days or half-days per week which he must work would not save him. If his position compelled him to take orders from the bailiff as to the particular place in which he must work or the particular . work to which he must turn his hand, there was a presumption that his tenure was villain. Of course, a free man might take up a villain tenure, and though at first the result of his doing so would often involve him in the character of his holding, as time went on and the hold of royal justice strengthened, he might mairain 
his personal freedom. But the tendency to judge a man's status by his ocenuation-a tendency strong enough even to-day-was doubly strong in the Middle Ages. And, apart from such possibilities, the freeholder, during the first century after the Conquest, was in a precarious position in view of the difficulty of getting legal remedy against actual ejection from his tenement. The popularity of the Assize of novel disseisin lends colour to the suspicion that at least in the times of Stephen the process of converting free hoteres into villains had proceeded rapidly.

It is not neressary to discuss the sereral legal types of free tenure, -nor need much be added as to the economic gradations. We shall carry with us the conception that the typical manor contained a minority of free tenants paying defined rents in money or kind and farly definite labour dues-the obligation, for instance, to perform a few days work at harvest, to carry messages occasionally, or the like. Their lor had the wardship of their heirs-a profitable business during this period - and was entitled to receive "reliefs" from them when he came into the property, when his eldest son was knighted, and so on. Amongst the villains we distinguish two chief classes; men who owed large labour dues in return for large holdings, and men who owed less for small holdings. The norm of large and small holdings respectively may be taken as thirty and five acres, and we may call the two classes virgaters and cotters. Additional rents in money or kind, together with liability to occasional calls and fines, were usually incident on both classes.

I. "Virgate" is derived from the Latin equivalent of yardland, ancl as far back as the laws of lne, we find lorets settling men on yardlands: more than three hundred years later the writer of the "Reetitudines" speakis of the yardland as the normal Gebur's holding: in the hundred rolls at the end of the thirteenth eentury we fimel the virgate the normal holding of landed rillains. Over the greater part of England the virgate was a fularter of the areal hide, amel, as measmes are derived from familiar ynantities, the hicle originally was the area which a normal ox team conld work in a year, together with a proportionate amome of the fallow and a share in pasture and waste; the amoment of land plomghed in a day was an arre. At the Noman Conquest the hide in most parts of England hard come to mean 120 acte strips lying in the common fieds, 
and the team implied eight oxen. A virgate implied thirty such strips, or often sixty half-strips and two oxen. As has been said, as late as the hundred rolls, the virgate remained the normal tenement of landed villains. We find, indeed, numerous aberrations from the norm: holdings larger or smaller. In most instances, however, the connection of such variants with the virgate is evident: they are $\frac{3}{4}, \frac{1}{2}$ or $\frac{1}{4}$ virgates, or $1 \frac{1}{4}, 1 \frac{1}{2}, 13$ virgates, $\frac{1}{2}$ hides, $\frac{3}{4}$ hitles, and so on. It is evident that we have here the result of two opposing forces: on the one hand the tendency to subdivision and increase chiefly by inheritance; on the other, some motive which prevented subdivision from going beyond a certain point. This latter force must be songht in the cenomic interest either of the tenant or of the lord, or of both.

(1) The interest of the tenant.

It seems certain that long after Domesday ploughing on the demesne with full teams of eight oxen continued, and that the virgaters combined their oxen to make up these teams: It is not certain, however, that coäration remained common on the acres of the virgaters themselves. If it did, it is clear that every subdivision of the virgate would increase the complication of the system. If it did not, subdivision would be still more wasteful, for since two oxen seem to have been a sufficient equipment for a virgate, the use of oxen would be disproportionately costly for any smaller holding. A holding of one quarter virgate, for instance, would reduce the tenant to that monstrous "semibos" of which a single specimen is recorded in Domestlay. Hence the tendency of virgate families to hold together is intelligible from the point of view of the tenant.

(2) The interest of the lord.

It may be doubted, however, whether these consitlerations would have preserved the normal holding against the lust for individual ownership had they not been re-enforced by a parallel interest of the lord. Both in regard to the collection of money and produce rents, and in regard to the farming of the demesue, his interest lay in grading the holdings in a small mumber of welldefined classes. "A good landlord was like a goot gardener, who has to ply the axe and the pruning-knife in order to rear a plantation of strong even trees." 1 There is docmmentary evitlence

1 Vinogradoff, "Growth of the Manor," p. 314, and note. 
in the shape of instructions to the bailiff that this was the view of at least some lords. It would have been inconvenient to rearrange constantly the obligations of a steadily-increasing number of dependents. The simpler method was to attach certain obligations to a particular holding, and make one person alwars responsible for their performance. The centre of these obligations was the socalled "week" work. Three, four, or even five dars a week, the virgater had to labour on the demesne at tasks set by the bailiff. He must join his oxen with those of other virgaters to make up the heary plough teams. He must bring his cart to carry crops or manure. Additional "boon" works were required at certain times of the year-especially at harvests. There were also payments of money or produce, though these were usually insignificant as compared with the "works." Further, he was liable to various "reliefs " and "fines" on special occasions. He paid "merchet" for licence to marry a daughter, and a fine if his son was put to work outside the manor. The amount of labour exacted shows that the virgater's household usually consisted of a number of adults - men and women. No single man could have worked five days a week on the demesne, and cultivated in addition with his own labour thirty acres of arable. It is clear that as time went on the labour obligations were de-personalised. So many days per week were due, but the virgater might send an efficient substitute. If he failed to attend or send a substitute a fine would be exacted. On the basis of such fines customary prices for a normal day's work grew up, and by-and-by the lord might acquiesce or insist on commutation of the labour dues or a part of them for money payments.

11. The lower class of rillains, the cotters, may have descended sometimes from virgaters in the physical sense, but it is not likely that the two classes had originally common obligations and similar holdings. We have seen the forces which made for persistency of the typical virgate, and it appears that the small holelings of the cotters did not usually consist of acre strips in the common fields. They were "crofters and holders of plots," and had "a very important part to play in the economic life of the manor." 1 It scems probable that their position originated in three ways.

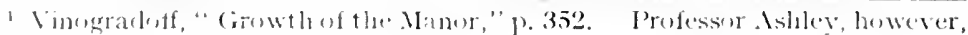

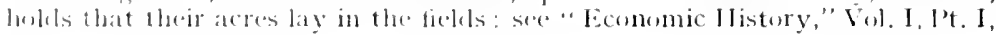
r. S. 
First, manumitted slaves may have been established on small patches of land, and more occasionally endowed with a few odd acres in the fields. Secondly, similar provision was made in all probability for the overflow of virgate households. Thirdly, it is likely that at the original settlement where the choice lay between enslaving conquered Welshmen and subjecting them to service and rent the latter alternative was preferred, but that they were not given full virgate holdings. As regards their economic importance in the manorial system the following points should be noted. (1) Their dissociation from the scheme of co-operative ploughing on the demesne made their enfranchisement a matter of comparatively small moment to the manorial economy. In their position there was naturally an element of labour-fluidity, just as there was an element of labour-rigidity in the position of the virgaters. (2) It was impossible for them to live off their small plots and pay their rent and the money commutation of their labour services. Hence their class is the natural origin of three other classes whose importance increased as time went on, (d) agricultural wage labourers, (b) village artisans, working for local demand, (c) manufacturers working for an extra-local market.

It will be seen that the communal element in the manorial system was very slight. Although little of the land was held severally in the modern sense, each family had strictly defined rights, and depended for its prosperity partly on the extent of those rights, and partly on the activity and diligence with which it used them. The division of the produce of land was arranged on strictly individualist lines. Each family took the crop from the land which it had worked itself, and though pasture was used in common, the extent of individual use was limited. If coäration was practised elsewhere than on the demesne it may be concluded that the system was nearer to individualist partnership than to collectivist control of the instruments of production. Where village artisans received holdings in return for their smith's work or carpentering, and where this arrangement was not merely an assignment of specific work by a manorial lord to his subject tenant, it was probably hedged carefully about by custom which had some of the harshness and none of the freedom of individual contract. The maintenance, again, of a common swineherd or beeward by a village no more implies communism than the maintenance of a common policeman implies it 
to-day. On the other hand, the manor tended without doubt to assign to each member of the community definite duties and make definite provision for his maintenance. To this extent it was, like the system of chattel slavery, a more social system than that of modern industry. There can never have been difficulty in providing employment whilst such close connection between production and consumption was maintained. and the disciplinary porvers of the manorial courts, in other words the element of personal slavery, checked no donbt such individual degradation as results to-day from the right to loaf. Of the position of the indigent on the manor very little is known. The widow of a villain was often allowed to retain his holding at a reduced or nominal rent until his son was grown up to take his place. It is clear also that the system was precisely suited to extract the maximum of good and the minimum of evil from the indiscriminate charity which the Church advocated. The priest, and every possible benefactor, could know the whole circumstances and the real character of every applicant for alms, could know also where charity was required. The compulsion to work would prevent charity from breeding idleness. It is probable that the professional beggar vagrants, who were a feature of English life in the fourteenth century, already existed in considerable numbers, but the percentage of able-bodied paupers among the resident members of manorial communities must have been very small.

In studying the regulation of labour by the manorial courts we come close to the problem of detemining the extent to which competitive forces were controlled by custom. The lord, or his representative, sitting in court, appealed to juries of the tenants against men who neglected their duty. When a holding passed at death to a new tenant, the duties incidental to the tenure were similarly declared by men who hat common knowledge of the affairs of the manor. The jury's business was to declare the custom which its members knew of their own experience, not to hear and draw conclusions from evidence submitted to them. Is time went on. the minutes of such courts were kept regularly. Case custom thus developed into case law. Now it is plain, first, that so far as the royal justice was concerned, a villatin tenant had no remedy against a lord who demanded from him an increased rent. The developing common law protected villains in their agreements and 
property against anyone except their lord, but seldom interfered between lord and villain. In the eve of the law a villain's property was the property of his lord, and he had no remedy against summary ejection from his holding. Secondly, it is clear that though by law the lord could fix or alter arbitrarily the terms on which the villains held land of hin, this arbitrary power was in practice little exercised. Most lords professed at least to bind themselves by the custom of the manor as declared in manorial courts by representative tenants. The conomic advantage of business-dike definition was not perhaps consciously realised, but it received the homage of silent practice. Thirlly, where comparison can be made of the customs on particular estates at different periods, it often appears that the labour services due from the tenants were gradually increased. It is thus evident that the custom was somehow elastic for all its professed rigidity. The increase in the value of the property to the lord does not of course preclude a parallel improvement in the standard of life of the tenants. There is, perhaps, no case in which the fact of such improvement can be demonstrated, but it can be inferred from the general history of the nation.

It must be supposed that the system of strip division of arable in the open fields had answered originally some serious social convenience. No trace of such advantage can be discovered in the economy of the medieval manor. On the contrary it hampered universally improvement of agricultural technique without contributing anything of ethical value. It was necessary for all the cultivators on the open fields to grow the same crops in the same way at the same time, and this led in practice to conservatism of the traditional rotation, since the assent of all parties was required for any change from one year to another. Much time was lost by the individual in passing from one part of his land to another. Much land was left idle to form boundaries between furlongs and acres. The weeds of the careless farmer spread to the crop of his more careful neighbour. The cattle infected one another on the common pasture. Experiment and hard work were alike at a discount. This is the general verdict of students of the system. It was reiterated by the agricultural improvers at the close of the eighteenth century. It was noted by Fitzherbert carly in the sixteenth century. Doubtless there were minor compensations. Some social pressure may have been brought to bear against the worst offences of 
individual negligence: but this could not ontweigh the sum of disadrantage. The author of a State paper in 1607 compared the conclition of "Northamptonshive and Somersett, the one most Champion, more ground, Litle Waste, the other all enclosed but inferiour in quantitie and quallitie: Yett, by aduantage of severaltie, and choice of emplorment exceedinge farre in People for the Musters, and Welthe." 1 The argument, of course, is false in method and inconclusive, though the difference to the advantage of somerset in the points indicated is enomous. More striking is the steady progress away from the open-field system, the beginnings of which can be traced in the medieval period. and which grew to such serious proportions in the fifteenth and sixteenth centuries.

It is certain that the population increased greatly between Domeslay and the Black Death. At the former date it may have reached 1,500,000, at the latter it was not less than $4,000,000$. Some part of this growth went, of course, to build up the town population, but the rural districts filled up also. The prevalence of Newtons and Vewfields shows that settlement spread by planting of new open-field villages or adding of new fields to those which already existed. It seems, however, that as time went on a different method of using reclaimed land grew in favour. Considerable plots were enclosed permanently by the lord of the manor and leased to tenants. The preference for several agriculture could show itself on new land. whilst it was still far too weak to break i1) the customary arrangement on land which had lain always in the open fields. The origin of severalty in open-field villages seems to be found in the messuage-the hedged-in plot within which stood the dwelling and the farm buildings of each family. The Hall and buildings of the manor were on a larger scale, and stood in a larger enclosure. The stock and poultry of the lord required additional space. Hence the few enclosures commonly found in the immediate neighbourhood of the Hall. The wealthier tenants would also early require similar provision. Further progress could be made so long as uncultivated land beyond the open fields remained in greater quantity than was required for the general needs of the village. The wording of the statute of Merton in 1235 indicates that this point had already been reached in many districts. It permits lords

1 (guted lyg (unningham, " (ivowth of linglish lndustry and commerce," *** 1). 898 . 
to enclose waste or pasture, so long as they leave to " knights and freeholders" "sufficient pasture so much as belongeth to their tenements." It is probable that eustom strove to give the villains the protection thus conferred by law on the free tenants. Further progress could not well be made without disturbing the arrangement of the arable, and there seems to be no sufficient eridlence to show whether or how far this was done. On the whole the probabilities are against it. The enclosure of the open fields of England was? accomplished in revolutionary manner at two different periods ${ }^{1}$ separated by a century-and-a-half. At each period exceptionally strong forces promoted a change of system. But the open fields which had survived the revolution between 1450 and 1600, in inost cases resisted successfully the minor economic momenta which attacked them down to 1760 . It is hardly credible that the system was less rigid in the thirteenth century than in the early eighteenth, and its persistence in other parts of the world confirms the impression that it has a resisting force which may / prevent change by degrees for centuries. though it can be broken up rapidly if the strain once passes a certain point.

On the other hand, the commutation of labour and produce into money rents proceeded steadily. Whilst it was difficult to alter the distribution of land for one person without recasting the whole system, each kind of produce or labour-due could in turn have its equivalent fixed in terms of money and be commuted gradually by one individual after another. The substitution of a cash nexus, for a personal servitude would usually result in increased production and increased freedom and advantage for both parties. Increased use of money within the manor depended upon increase of trade between each manor and the outside world. It will be seen later that the English export trade in wool expanded rapidly in the thirteenth century, but evidently side by side with the expansion of foreign trade went on even more rapidly the growth of trade between town centres and the surrounding country. Theoretically, of course, the lord or his agent exclusively might have introduced the necessary supply of money: might have paid it out in wages and drawn it in again in rents. They could have obtained it in the first instance by selling part of the produce of the demesne

'See below: p. 109. 
farm. It is equally possible that the tenants, by sale of part of the produce of their own land, could accumulate reserves which would ultimately justify them in offering to substitute money-payments for labour and produce. There is no such evidence as would enable us to decide between these alternatives. Probably both causes operated. but the fact that the lords generally came to regard their manors as a direct source of money income seems to show that the latter cause was the more important. It is in particular clear that the lords were always more eager to commute produce-rents than to commute labour services, and, in regard to labour, were readier to release the cotters than the virgaters. Evidently, whilst ready enough to receive cash, they were not over eager to pay wages. They wanted surplus money, as much as they could get. to spend on military enterprise. Thus, long before the system of demesne farming by servile labour was seriously shaken, the business relations between indiridual tenants had reached a cash basis. The village artisans worked for payment by the piece, and the scores of those who frequented the village alehouse were ultimately discharged in coin. In addition to food and raw materials it is probable that rough cloth and linen made by the villains' families early became a staple article of commerce between manor and town.v

The produce of the demesne lands had originally been consu med directly by the lord and his establishment-partly on the manor when he occasionally visited it, principally at one or other of his castles throughout the country. In the records of ecclesiastical corporations are found traces of elaborate arrangements for the regular victualling of monastery or cathedral chapter from a number of manors. Until the reign of Henry I some royal manors sent supplies direct to the Court, and this system was continued no doubt in the case of the smaller lords until after the Black Death. The larger estates began much earlier to market the produce of the demesnes on their component manors. We thus find the great nobles and the ecclesiastical corporations building up large commercial enterprises in the twelfth and thirteenth centuries, and making larger sales of wool, and leather, and corn, and smaller sales of rude manufactures, such as hurdles. Only exceptionally, lowever, did a great man become really interested and involved in the developing commercial machinery of the country. The sale of the produce of each manor was managed by the bailiff, who had 
enough to do in organising the work of the estate, and could not pay much attention to market conditions. Hence these surplus products of the demesnes, together with the smaller surpluses of free tenants and villains, rarely led the members of the manorial community to renture far beyond its borders. The work and profit of collecting and distributing these supplies was taken up by the growing number of foreign and native traders. The division of sentiment and interest between aristocrat and trader continued. Still more important was the persistent division between producer and trader. and the resultant slow reaction of supply to demand. Ien went on producing what their fathers had produced, and took whatever price they could get for their surplus. The problem of so knitting together production, exchange, and consumption as to maximise the return to labour came slowly into men's minds in the succeeding centuries.

The monotonous cellular structure of rural England in the twelfth and thirteenth centuries is broken occasionally by interesting experiments. Thus, whilst the demesne was usually farmed by a bailiff in the interest of the lord, it was sometimes let to an enterprising tenant who paid a money-rent for the land and the stock upon it. Such arrangements are most often found between ecclesiastical corporations and one or more of their nembers. They imply a certain equality between the contracting parties, and this was almost excluded where the landlord was a noble. A still rarer expedient was the payment of a rent for which the tenants were jointly and severally responsible and the distribution of the demesne acres among them. This was analogous to. and possibly sometimes the first stage in, the process by which a rising borough escaped from the direct government and detailed supervision of its iord. , It argued a power of foresight and co-operation which was seldom present among the villains; nor can they have been often in a position to offer the lord any substantial guarantee against exploiting his land until it no longer would produce the rent agreed upon. The higher level of intelligence which prevailed in the towns as a result of contact with the outside world was capable of constructive action. The spirit of association was present on the manors, but it showed itself there chiefly as a sullen, resistent force. Trade made progress a present reality to the burgess, and the fact produced the ideal. On the manors change was so slow that it escaped notice, and the . 
hope of the villain lay in conservatism. That he was capable of reacting when a different stimulus was applied hecame clear in the fourteenth century. "When Adam delved and Eve span. who was then the gentleman?" was the watchword not of burgesses but of villains. But rural England after the Black Death was in every way different from rural England in the thirteenth century. In the words of Mr. Daris. "Of all the contrasts which strike us in medieval life. none is so acute as that between the intellectual fument in the upper classes and the oriental passivity of their inferiors." 1

1. H. W. C. Haris, "England muler the Nomans and Angerins," p. 516. 


\section{CHAPTER III}

URBAN TRADE AND HANDICRAFT

SIDE by side with the manor the town developed - the second of the two chief types of communal life in the lliddle Ages. Numerjcally the town dwellers could not compare with the inhabitants of the manors, but this inferiority was more than counterbalanced by superior wealth and activity. We have seen that until the Norman Conquest the chief causes of differentiation between urban . and rural life were the expenditure of the aristocracy and the Church. The position of towns was determined sometimes by military needs. sometimes by the presence of a monastery or cathedral, sometimes by the pre-existence of a more primitive centre of trade at the intersection of roads or at the ports where they left the coast. In many cases two or all causes co-operated. The masses who tilled the soil consumed little that was not produced directly by themselves, their families, or the village artisans. But each village gave up part of its produce to Crown, Church, or aristocracy. The wealth thus concentrated hired soldiers and maintained monks and priests; it employed a small army of personal attendants on great men; and both directly through the expenditure of the great, and indirectly through the expenditure of their dependents. provided a basis for specialised trade and handicraft.

The firmer central govermment which followed the Conquest tended undoubtedly to break down the barriers which separated the workers in each village from the outside world. But, as we hare seen, the self-sufficiency of the village community was little affected for several centuries. Yet the Conquest is rightly connected by political historians with the subsequent rapid expansion of town life. The new aristocracy differed from the old, both in greater "ill and in greater power to effect this development. By increasing the burdens of the masses in the first instance, and later by improsing the technique of manorial farming, they gained a larger surplus for personal expenditure, whilst their higher standard of civilisation 
demanded a refined consumption, the means to which could only be supplied by specialised trade and handicraft. To this may be added the influence of more elaborate government. of garrisons, and of ecclesiastical corporations. Every new castle and every cathedral or monastery required an embryo town without its gates. It is probable that until the thirteenth century these were the principal causes of urban growth. They have, indeed, in some cases remained the predominant canse until our own day, and were important in very many cases until the industrial revolution. But already in the Middle Ages the fowns were losing their original personal connection with lord. or bishop. or abbot. or court. In so far as they still depended ultimately on the revenues of the great, that dependence was becoming generalised and lost sight of through increasing exchange between town and town, and between England and the ontside world. As the productive power of the craftsmen increased with specialisation, each town in turn became a market for the wares of other cities. and although in the main. the villages remained self-sufficient. vet the very minuteness of their traffic with the towns permitted its rapid increase.

It is far harker to weave into a comnected narrative the rise of urban institutions than to describe the manorial system. The differences between the manors over the more thickly populated counties of the south and east were from this point of view less important than the differences between the towns. In the manors the same begimnings of change are everywhere manifest in the thirtenth century. In the fourteenth century one and the same revolution produced in most of them very similar results. In the towns, on the other hand, althongh close institutional parallels meet us on every hand, it is hard to say that any one type of organisation prevailed in any one half-century. A stage of development which was reached by one town early in the twelf th centurymight be deferred a hundred vears in another. One cause was the relatively salder difference between the size and importance of town and town. No one manor differed foom another in the measure in which London differes from Coventry. Again. the highly artifictal character of borough privilege, dependent on the will of individual lords, and on opportunity wisely grasped by the bugesses. trended to differentiate development. It is none the less important to outline the principal phases through which a 
large number, probably the majority, of the towns passect, and to trace as far as it is possible the relation between each phase and the economic clanges induced by the gradual growth of exchange.

I. At the outset the embryo municipality is but slightly differentiated from a manorial village. The majority of the burgesses are still occupied principally in cultivating their common fields, a minority only have specialised on trade or handicraft. Their privilege consists in greater security of property and more personal freedom. Special provision has been made to prevent theft or violence, to record bargains, and to limit the power of the lord to annex by arbitrary fines the whole profits of trade and production. , The burgess is raised above the status of the villain, or is saved from sinking to it, labour-dues have mostly been commuted into money-rents, and a certain freedom in the choice of occupation exists.

II. A second stage is reached when the numbers and wealth of the burgesses have grown so large that they can complete the process of buying off the miscellaneous rights of their lord and purchase a charter of self-government. At the same stage emerges the first formal organisation of an economical or at least nonpolitical character-the gild merchant. It controls trade and production within the town and represents the economic interests of the town in the outside world.

III. Further growth of numbers and complexity makes it difficult for a single body to grapple successfully with the task of policing the rapidly-increasing divisions of industry. As increase of numbers makes pressure of public opinion less immediately operative on the individual, the business of legislation in regard to economic matters is claimed by the municipality. As a result of these two forces the gild merchant loses its importance as a separate institution; its legislative and judicial authority is ceded to the municipality, its executive functions are divided among a number of "crafts" or " misteries," each of which is responsible for a particular trade or industry.

IV. Further progress breaks down the clear demarcation between town and country, and reduces the majority of craftsmen to the rank of wage-earning dependents upon capitalist middlementraders, speculators, and organisers of industry. The central 
govermment makes inroads into the legislative powers of the municipality and gradually dispenses with the executive work of the crafts. It is in this perjod that the towns lose their specific importance in the history of industrial organisation which requires to be treated thenceforward from the broader standpoint of national development.

In the present chapter we shall be concened with the first three only of these phases and especially with the second and the process of transition from it to the third. If we try to define the actual dates which may be assigned to the se in English town development, we are met at once by the difficulty noted above, that some towns developed more rapielly than others. The gild merchant did not becone common until the second half of the twelfth century, but specialised craft-gilels existed in several towns before 1150. Nevertheless the century-and-a-half from 1150 to 1300 may be assigned to our second phase, the century from 1250 to 1350 as marking the transition from the seconel to the third. the fifteenth and the first half of the sixteenth century ats the period during which the third was predominant. It is probable that the economic conditions which chanacterise the second phase exister alreaty in a few places at the time of the Confuest. London, the Cinque Ports. Winchester, and Exeter may be instanced. The earliest evidence of a gild merchant in an English town falls within the years 1093 and 1107 . It is mentioned in town charters with incratsing frequency from the reign of Henry I onwards. But the ('incue Ports probably, and Lomelon certainly, possessed of immemorial usage the right of trade in all English towns which was one of the privileges nomally confermed by the grant of a gild merchant. It is not clear that

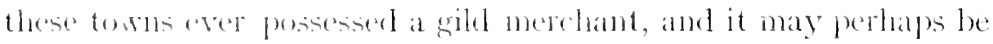
inferrel that, having olutained the sulstance at an earlicr date, they did not repuire the formal institution. The Pipe Roll for 1130 p gives the first evirence for the existenee of craltegilds. At that date the weavers were separately organised in I,ondon, Lincoln, and

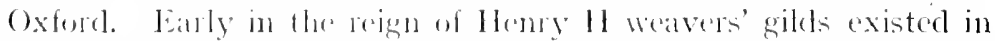
York, Winchester, Ihutinglon, and Nottimgham. At l'inchester the fullere were separately organiserl. The notice of "adulterine"

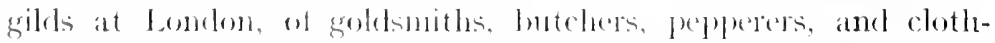
finshors in 1180 is important ats showing that such booles might conne into existence belone recering any legal status. It is clear 
that in the more important towns craft-gilds multiplied towards the end of the thirteenth century. Occasionally their rise was marked by conflict with the older established gild merchants. In the fourteenth century the towns accepted the new system of organisation as inevitable, and it rapidly supplanted the old.

The great increase in the demand for traders and craftsmen which followed the Norman Conquest made the new aristocracy liberal in the grant of such "customs" as raised the manorial village into the first urban phase. Often, it appears, these customs were imported wholesale from the Continent. Thus the little Norman town, Breteuil, became the parent of a number of English cities. A similar process of affiliation from one to another English town can also be demonstrated. But, although the new lordswere anxious to make possible the nucleus of town population which they required, they were not anxious to part with more than the inevitable minimum of their direct control. However rapid might be the growth in the number and wealth of the burgesses, it was still difficult for the city to reach the second phase, for the power of direct taxation through his own officials was worth more to the lord or the Crown than any fixed rent which the burgesses might be prepared to pay for the right of self-government. Fortunately for the towns both Crown and nobility were frequently in want of ready money during the twelfth and thirteenth centuries, and it was to special chances of this kind that many places owed their charters. The Crusades were peculiarly fertile of such opportunities, and upon the whole, escape was easier for towns under the lordship of the lay nobility or the Crown than for those in the power of the Church. There was thus a certain element of artificiality in the transition from the first to the second phase. Of two towns which had attained the requisite degree of economic development one might have or seize its opportunity, another might neglect it or be denied it altogether. Once the charter was secured, however. differentiation would in most cases proceed rapidly. The advantage of political privilege would outweigh a considerable inferiority in geographical position; it provided, on the one hand, a firmer basis for the accumulation of wealth within the town, on the other it gave the burgesses a standing in their dealings with other municipalities.

The grant of a charter was usually accompanied or followed by 
permission to the burgesses to organise a gild merchant. Its members had a monopoly of trade within the town. No "foreigner" might sell te, or buy from anyone in the town except a member. A natural corollary of this privilege was authority to regulate the conditions under which trade or production should be carried on within the town. Members were further usually privileged to trade all over the country without liability to exceptional tolls. Hembership served as an introduction to the trader in other towns, at home and abroad. The association recovered debts due to its members from th: members of other associations, and in return was liable for debts contracted by its members in other towns. These lacts indicate that from a very early period trade between different towns played an important part in the urban life of this country. It is perhaps doubtful whether the distinction drawn hy some historians between an initial period of town development, when each centre deats with the surrounding county, and a second period of intermunicipal trade has any serious basis in fact. The demand of the wealthy played the chief part in the first stage of town development, and this postulated from the first intermunicipal trade as well as exchange between town centres and the surrounding country.

Membership of the gild merchant was not necessarily coextensive with ritizen-hip. Lsually a burgess had to pay a certain fee before lie became a member, unless he succeeked as eldest or youngest son to the seat of his father, and "stringers" could often become members loy paying at somewhat higher fee. It was often advantageens to local landowners whose estates yielded a vendible surplus to sarr mirkllemen's profits by taking out a franchise. Again the gild merchant often contained a number of burgesses betonging to other towns who harl important tradre comections with the place. Nevertheles the relation between membership of the sild and citizenship, was alwatys close, and in some cases the two bodies came in time to lu molistinguishable. This, howerer, seems to have hatpened only when the practical importance of a gild merchant latel fecityel. It is impertant to notice that the "merchants" in the gild were not exclusively traders: it seems always to have included a large number of craftsmen. Thus the first woll of the locicester gild merchant gives anomg otlere trate names the following: weaver, dyer, wowl-comber, chothdubler, shearman, tailor, 
hosier, tamer, leather-worker. shoe-maker, and sadkler. The fact that we still use the term trade in reference (a) to mere dealers, $c . g$., retail shopkeepers, (b) to mere producers, $c . g$.. momber of a trade union. suggests that at one time the two classes were hardly distinguished, and it seems that in the twelfth and thirtenth centuries there was in fact in England no great dissinilarity between the position of the majority of merchants and craftsmen. The latter bought material, manipulated it, and sold the finished article, or made to a customer's order as a village tailor will to-day: the former bought goods in one place and personally conducted them to another. There was little more scope for the merchant than for the craftsman to organise and speculate, whilst the craftsman had upon the whole more hope than the merchant of prospering abnormally, in virtue of superior dexterity or artistic skill. These conditions remained substantially unchanged until late in the thirteenth century, and it was even later that the foreign trade of the country began to be captured by natives.

These facts have an important bearing on the difficult problem of the transition of English towns from the single gild merchant to multiplied crafts and misteries. Both in England and in many Continental towns this process occupied roughly the same period, viz. the thirteenth and fourteenth centuries, although it is probable. that the change was on the whole somewhat later in England. This superficial resemblance conceals. however, a very important difference between the course of events here and abroad. On the Continent the formation of craft gilds was usually part of a democratic movement, and implied that the industrial workers were throwing off their dependence on capitalistic traders. In England there is no sign of any such general movement. As merchants and craftsmen had lived within the gild merchant on a footing of democratic equality, so separate organisations of merchants and craftsmen emerged without suspicion of conflict between capital and labour. Such conflict did, indeed, as will be seen later, become increasingly common as the fourteenth century proceeded. It occurred, however, as often as not between members of one and the same craft, or between one craft and another, not between craftsmen as such on the one hand and a separately organised oligarchy of capitalist traders on the other. This difference between the evolution in England and on the Continent implies such substantial 
equality of merchants and craftsmen within the common organisation of the English gild merchant as is suggested by the list of trades represented on the Leicester roll. It is borne out by much additional evidence. The Flemish and German cities of the thirteentlı century were evidentiy governed by oligarchies of merchants whose wealth was very considerable. In England, eren in the middle of the fourteenth century, only some one hundred and sixty individuals gained large incomes by trade; alike for foreign trade and for national finanre the country was dependent upon the larger capital of Italian and Flemisly houses.

It is important to realise that the lack of conflict between capital and labour in medieval England was a result not of superior social organisation or of peculiar national character, but merely of the absence of the econonic conditions which engendered such conflict. The class of dependent wage-earners employed for the profit of entrepreneurs had hardly come into existence. But in view of the rapid development of this class in the fourteenth and fifteenth centuries, we shall be on the look-out for its occasional appearance at earlier dates, and if we find occasional traces of conflict between trader and craftsman, we shall be prepared to explain them in this way. We shall not feel that our general theory must be abandoned, unless all exceptions can be traced back to some artificial cause. Thus, for instance. the exceptional size of London and the constant vaunts of its wealth in the twelfth and thirteenth century chronicles prepare us to find there conditions more analogous to those of Flemith citics than could exist in most English towns.

If it is granted that the fact of general equality between merchant and craftsman does not require us to regard with suspicion all traces of occasional conflict, but rather to expect it in towns or industrics which had developed previously, we slatl go on to inquire whether any industry or industries were specially likely to be the scene of such difficulties. It has been pointed out by several writers that the position of the cloth industry was peculiar in that some considerable trade in cloth existed contemporaneously with, if not before the establishment of weaving as a specialised urban handicraft. A knowledge of the simpler processes of cloth manufacture was conmon to all Indo-European races, and accordingly we find the production of rough eloth part of the normal work on the medieval manor. So far there is no distinction between primitive cloth and 
primitive metal-manufactures, but trade in cloth developed much earlier than trade in metal goods. As early as the reign of Alfred the English depended upon the Continent for supplies of the finer qualities which were not produced at lome, and this condition remained substantially unchanged until the end of the sixteenth century. The English, however, in the thirteenth century were already building up an export trade in unfinished cloth, and trade in unfinished and rough cloth between different parts of the comntry must have been considerable at a far carlier period. Although no doubt most manors produced enough for their own needs, the supplies required by the extra-manorial population wonld be drawn from those parts of the country where wool was produced most easily. The early importance of the trade is made evident by the fact that as early as the reign of Richard I attempts were made to enforce a national assize of cloth.

The first textile craftsmen in the towns, therefore, were not like most of their fellows, supplying a demand which conld not be met by trade. There was possibility of friction between them and the town merchants in two directions. First, they could supply part of the local demand, and second, part of the demand of travelling merchants who visited the town with the object of collecting cloth. It is plain, also, that the interest of the merchants would lie in restricting the craftsman's freedom of trade rather than his freedom of production. If they could retain in their own hands the monopoly of the trading function, it might be even more advantageous to them to have the supply at their own door than to seek it in the manors. The peculiar position of the cloth industry makes what is known of the early textile craft-gilds exceedingly interesting. Ashley has drawn attention to the laws of the weavers and fullers of Winchester, Oxford. Beverley, and Marlborough. " These laws draw a sharp distinction between the craftsman and the freeman . . of the town. . No wearer or fuller might go outside the town to sell his own cloth, and so interfere with the monopoly of the merchants; nor was he allowed to sell his cloth to any save a merchant of the town."1 A craftsman might become a merchant. but " he must first forswear his craft and get rid of all his tools from his house." 2 Dr. Cunningham has argued with great

\footnotetext{
1 Ashley, "Economic History," Vol. I, Pt. I, P. 83.

2 Ibid.
} 
ingenuity that these early gilds of weavers were the fruit of an immigration of Flemish artisans soon after the Conquest, and that the friction between municipality or gild merchant and weavers' crafts is referable to the foreign origin, and consequently privileged position of the latter. The positive evidence for this view is admitted to be weak. but it is claimed that as a working hypothesis it clears up the difficulty that disputes did oecur in England, although the English gild merchant included merchants and craftsmen on an equal footing. In the preceding pages an altemative explanation of this difficulty has been put forward: but its acceptance does not involve rejection of the whole of Dr. Cumningham's hypothesis. It seems certain that craftsmen as well as traders came over in considerable numbers after the Conquest, and it is likely enough that there were many weavers among them. It may. however, be questioned whether the majority of such craftsmen were weavers. A priori it would be likely that men of very various crafts would be required and would come: but if so it is extraordinary that friction should have been confmed to the wearers, mless some economic cause of friction stimulated the racial jealonsy.

We have seen that the chief functions of the gild merchant were to regulate the economic life of the town and to represent its members in dealings with other towns. In regard to regulation, trade rather than production was the object. Each member was felt to have a right to an equitable share in the trade of the town, and hence one member might usually claim a part in a transaction between another member and the outside world. All members were expected to deal openly in their assigned place in the common market. It is probable that common purchases were often made. and that loans were made to members out of a common chest. In addition the gild provided for social meetings of its members, for their relief in sickness or misfortune, and for common religions offices. We do not find, on the other hand, those claborate regulations of quality, process and price which were so important to the later craft gilds, and this distinction is a che to the causes which promoted the change from one method of organisation to another. The operative catuse seems to have been a gradual widening of the market as the population of the towns increased and their trading area became larger. 
I. If we go back for a moment to the village artisan we shall seve that this single producer working for a small number of consumers will not need elaborate and defined rules, although his econonic status may be strictly limited by custom. On the one hand, com. paratively little of his time will be spent on turning ont "graded" commodities in expectation of custom. For the most part he will work to order, and it will seldom happen that one order will be precisely identical with another. This by itself will make detailed regulation more difficult. More important. however, is the fact of his relation to the village. He has no body of fellow-workers with interests identical with his own, but antagonistic to the rest of the world. If he scamps his work, or extorts more than the customary fair price, he injures members of the class from whom his friends, if he have any. must inevitably be drawn.

II. As the village grows into the town. as population and the demand for specialised work increase, the situation gradually alters. Five or six smiths or carpenters may now be found working side by side at similar tasks, and as their number increases a double possibility of friction emerges. On the one hand they may cheat one another, on the other they may combine together against the general public. The development. however. of these difficulties will be slow, for the community will still be so small that each indiridual will feel the interests of the whole more strongly than the interests of his own trade. Still it will be convenient to make measures that no one of these craftsmen shall secure a monopoly of raw material, and therefore each shall have a right to share in a bargain made by another. Again we will make the market as easily cognisable as may be to each of them and to the general public. and therefore we will forbid them to sell, except openly. will have their workshops all in one street. and assign a certain position to them in the market. We have reached. in fact, the stage at which the gild merchant is desirable and can still do all that is necessary.

III. But the numbers in each craft increase still more. in spite of progressive subdivision of labour. The individual is less and less well kno:n to the majority of his customers. He may continue to sell directly to the consumer or to take his orders. but he meets him on a business footing. His friends are other men of his own calling. Again, as consumption increases, the making of roughly "graded" commodities grows in importance. A customer wishes 
a length of cloth, or a knife, or a pair of spurs. He knows what he wants, but knows little of its make, and can easily be imposed upon by inferior quality. The demand for more elaborate regulation comes from both sides. The individual craftsman himself is usually anxions to be protected from unfair competition, the consumer wishes protection from unfair extortion. Even if he still considers himself a judge of the article when he sees it, he knows that he can no longer bring to bear the direct personal pressure which was possible when men were fewer. A complexity of economic life has been reached which the simple gild merchant is no longer competent to deal with, and gradually the specialised organisation of trade or craft emerges.

We may pass on now to the several kinds of trade and handicraft to which the conditions of the time would give rise. Our traders will fall into two principal groups-(1) those concerned with imported products, especially wine, spices, and valuable personal possessions, particularly furs, silk, and cloth of fine quality, and (2) those concerned with native products, especially food, leather. wool, and cloth. The former class was probably only occasionally found outside London and a few other ports. Ashley points out that "the articles most frequently mentioned in the gild documents - skins, wool. corn, etc. - Show that the trade consisted almost entirely in the sale and purchase of the raw products of agriculture." 1 An exception may, however, be made perhaps in favour of wine. There was little of strictly retail trade; consumers made their purchases cither in market or at occasional fairs. Such shops as existed were mostly on the border-line between craft and trade. The innkeper brewed lis own beer. The same man baked and sold bread. Passing on to the crafts we may distinguish (1) a group occupied with preparing material for or making chothes and personial equipment, which again falls into the two sub-classes of textile workers and workers in leather, (2) a group of metal workers who fall similarly into a few broad divisions, coiners and goldsmiths, blacksmiths, whitesmiths, makers of weapons and amour, (3) a group of workers in woorl, as carjenters, whedwrights, makers of bows, arrows, etc. Many more gromps might of course be made, but the great majority of the subsequently specialised crafts resulted from subdivision

1. Isllky, "Jiconomic Ilistery," Vol. I, I’t. I, p. 79. 
within those mentioned. A word, however, should be adked on the building trades. It is clear that the mason's craft (bricks cane into use at a later date) must have been among the earliest specialised employments, and it is almost inconceivable that it remained without organisation. But, probably in consequence of the migratory character of the craft, it does not seem to have ever occupied an important place in the life of any one town, and hence the material for its history is unusually scanty. With this important exception it does not appear that the English craftsmen travelled much about the country. An important difference between the later development of the craft system in England and on the continent was that the years of travelling (Wanderjahre) on the expoiration of apprenticeship were not enforced here.

As the number of craftsmen and traders in a town multiplied, and the total output or turnover of each group increased, very important differences of industrial structure developed, resulting especially from the degree and kind of specialisation which was feasible in each case. The larger demand led sometimes merely to duplicated production-the numbers employed increased: but the individual continued to work in the old way. In other cases each individual while purchasing his raw material and selling his finished product in the old way, confined his labour to a small number of processes, or to a single process. The divisions of labour introduced might be (a) vertical, producing a number of coordinated groups all using the same raw material but independent of one another, or $(b)$ horizontal, where the successive processes required for the production of a single finished article were distributed to separate groups. In either case continued increase in output led usually to specialisation of the trading function. The business of supplying the raw material and of marketing the finished article passed more and more out of the hands of the craftsman who became dependent on a group or groups of merchant capitalists. Lastly, the chief result of increased production might be growth in the size of the normal business unit, specialisation proceeding within the business only, and not causing an increase in the number of distinguishable trades.

I. Mere duplication. This occurred where $(a)$ sub-division of processes into distinct trades was difficult or impossible, (b) direct relations between consumer and producer were necessary. In the 
baking industry, although some division of labour could be effected, all the processes which lay between flour and bread had to be performed under one roof. Further, inasmuch as no great outlay of capital was required, and every increase in the average distance between producer and purchaser was a disadvantage. the size of the normal business did not grow much. As the town extended, so did the number of independent bakers. Similar conditions prevailed in most of the industries whose chicf work was to execute repairs or customers orders-for instance, tailoring, carpentering, shoemaking, etc., and all kinds of hawking.

II. Multiplication of independent craftsmen in a larger number of specialised crafts was characteristic of the metal, textile, and leather groups - the workers in precious metals form an exception which will be considered later. In all these cases the economy obtainable by specialised dexterity was very great, whilst, so long as the bulk of the work was done for local consumption, a considerable measure of independence could be retained. In the industries which used iron. tin. and copper as their raw materials, an immense subdivision of crafts took place. We may give some instances. The making of spurs, buckles, pins, sword-blades, sword sheaths, all came to be distinct crafts. This was a case of what was called above rertical subdivision. The several crafts spread out without any interdependence from their common basis in the raw material. The woollen industry, on the other hand, supplies the best case of horizontal clearage, a number of integrated processes-spinning, weaving. dyeing, fulling, etc.-became the work of separate crafts, each of which contributed to the manufacture of one and the same article. The cause of this difference is interesting. In itself one kind of finished cloth is as different from another as one kind of nail from another, whilst the making of a nail can be separated into at least as many processes as the making of a piece of cloth. It appears, however. that (!) the relatively greater cost of carriage in the case of nails reduced the nail-makers in each town to work only for the local demand, and thens limited the possibility of further subdivision, at a time when cloth was alseady being distributed from a number of centres orer very consiclerable areas. (b) whereas every kind of nail conld be made erpually well at every centre, the power to make a particular kind of eloth was less easily transferable. It depended on local peruliarities of atmosphere, raw material, water, or accessible 
dyes, or on the traditional skill of a few highly-specialised finishers. and it was largely due to this peculiarity that the textile crafts showed the tendency to pass under the control of capitalist traders at a somewhat earlier date than the metal crafts. As the population of each district was not prepared to restrict its consumption of cloth to the varieties produced locally, a certain proportion of the total output had to be marketed at a distance, and with every increase in this proportion increased the dependence of the craftsmen on the traders who undertook these distant sales. This happened first in the woollen industry. but it became the fate of each craft in turn as soon as it secured a market so distant that direct relations between craftsmen and consumer could no longer be maintained.

III. Growth in the normal business unit was almost confined in the Niddle Ages to trading enterprises which involved considerable outlay of capital and long returns. and to the one craft whose raw material was so valuable that large capital was required-viz. the working of the precious metals. The earliest trading concerns in England which operated on a large scale provisioned considerable centres of population from a distance: our earliest city magnates were wholesale dealers in fish. meat. corn. and beer. As the export trade in wool developed, and still more with the growth of foreign and domestic trade in cloth. new roads to wealth opened up. The import trade into Londion, together with the ever-growing demand for gold and silver plate in that town, produced there a considerable body of wealthy merchants at a time when they were exceptional everywhere else in the country. But for all the boasts of chroniclers it must be remembered that in the fourteenth century it was still necessary for the Crown to appeal to foreign houses for financial support, and that the fight to secure for the nation the profits of foreign trade was only at its beginning. 


\section{CHAPTER IV}

NATIONAL CONTROL-TRADE, MONEY, TAYATION

EAcH local unit in the Middle Ages, whether manor or town, had a certain insularity to the rest of the world, the closest modern analogy being the division between sovereign states. As regards conomic matters, this implied that the man who passed outside the system in which he had grown up, found himself as it were in a foreign country. whose laws and customs differed from those which he had known, and where his own position so far from being determined by birthright was matter for discussion, arrangement and negotiation. In Book II we shall be largely concerned with tracing, the process which gradually removed these stiff internal divisions. But while that process was hardly begun-whilst increasing social consciousness and will were defining distinctions more clearly rather than sweeping them away-a national economy in a limited degree already existed. The measure of this national economy and of its gradual development is to be found in the activities of the Central Government. The minimum of security for the life and property of all English subjects which was gradually provided by the royal Courts, is the starting point, but a detailed discussion of this would lead us outsicle the sphere of economic history in the strict sense. We must confine our attention to the general policy by which the Crown promoted and regulated rxchange and to the growth of national finance.

The frist strictly economic duty undertaken by the central Government was the provision of currency and regulation of weights and measures. At the time of the conquest. and from that date until the thirteenth century, the only coins struck were silver pence. Early in the thirteenth century round halfence and farthings were issued, divisionary curency having previously been made by the people for themselves by hatving and quartering round pence. The issue of gold coins by Henry Ill was premature. Their value was too great for them to be convenient. It 
was not until the reign of Edward III that the currency problem was complicated by the double standard. Intil the issue of golle commenced, the silver penny was the most valuable coin in circulation. For convenience of reckoning larger units, the shilling and the pound. were used, and from the Conquest the relation of these units to the penny seems to have been fixed to the familiar equations 12 pence $=1$ shilling, 20 slillings $=1$ pound. In paying over large sums the coined pence were usually taken by weight, and not by tale.

Four conditions need to be fulfilled if a country is to secure a satisfactory current coin, where the problein is complicated by international trade. First, the right of coinage must be monopolised by some central authority; second, that authority must abstain from falsifying the currency: third, the technique of coining must be adequate to prevent either the circulation of false money or the deliberate debasing of true money; fouth, machinery must be provided for withdrawing automaticaliy from circulation those coins which are lightened by wear. In the period under consideration the two first of these conditions were fulfilled, the two last were not. Excepting in the reign of Stephen, the Crown practically monopolised the riglit of issue. The Archbishops of Canterbury and York retained, indeed, and occasionally exercised, the privilege until the sixteenth century, but their issues were not important, nor did they depart from the standards set by the Crown. Secondly, the same standard of fineness was preserved. so far as imperfect technique permitted, throughout the period. Every twelve onnces of coin issued were intended by the Crown to contain eleven ounces two pennyweights of fine silver and eighteen pennyweights of alloy. The weight of the pence issued seems to have differed slightly, but at the beginning of the reign of Edward I the weight was still in intention what it had been at the Conquest, viz., thirty-two good grains of wheat in the midst of the ear. ${ }^{1}$ Thirdly, the technique of coining was not adequate to make individual coins correspond exactly to the ideal standards. Fraud, therefore, was exceedingly easy. The individual coins, as they came from the moneyer, differed somewhat in fineness, and still more in weight, their shape was not

1 From 1180 onwards $22 \frac{1}{2}$ grs. troy were counted as the erpuvalent of the 32 wheat grains. Before that date the coins were probalny somewhat lighter. Cf. Ashley, "Economic History," Vol. I, Pt. I, 1. 171. 
exactly circular, the design was not sharply impressed, the edges were not milled or inscribed. This led (1) to various frauds on the true coins, the heavier ones were picked out and either melted or reduced in weight by clipping, filing, or "sweating," (2) to a considerable circulation of forged pieces and of inferior foreign currencies. Fourthly, these defects tended to reduce the average intrinsic value of the coins in circulation below the level maintained by the Government in its new issues, with the result that the demand for export or for plate steadily swept the newest and heariest coins into the melting pot. The machinery provided to meet this difficulty was necessarily imperfect. It is clear that the only complete remedy would have been the withdrawal of light and base coin at the expense of the Government, full-weight coin being issued in exchange. Such a plan was not really practicable so long as the Government was unable to secure that all the coins issued should have the same weight and fineness, for men could have made a living by demanding full-weight money in exchange for clipped and sweated coins. The alternatives were to impose very heavy penalties on falsifiers, and occasionally to attempt to throw the cost of recoinage upon actual holders of light coins. Both expedients were adopted, but ineritably with only partial success.

Next in importance to the issue of a national currency comes regulation of weights and measures. As early as the reign of Edgar we find it enacted that weights and measures should everywhere be the same as at London and Winchester; but little was done, apparently, to enforce uniformity before the reign of Richard 1. The Assize of 1197 provides for uniform measures of dry and liquid capacity, of weight, and of length. Four or six lawful men were to be appointed in every town to enforce the assize, and, according to tradition, the measures everywhere were compared with standards which were subsequently kept in London. Modern experience suggests the difficulty of imposing a common standard on local differences, and it seems clear that progress was exceedingly slow. Uniformity was recognised as desirable for the chief commercial commodities, but probably not for commodities whose circulation wats merely local. Thus a clause of Magna Carta lays down that there be "one measure for wine throughout our realm, and one measure for ale, and one measure for corn, namely the London quarter, and one brearlth for cloths ..., namely two ells between 
the lists: and be it the same with weights as with measures." Enactment by itself was of little use: persistent administration was necessary. The best opportunities were offered by the journeys of the Court through the realm. On these journeys the problem of accurate measurement would constantly come up in connection with the commissariat. Indeed, some historians incline to see in the necessities of the itinerant Court, rather than in the general requirements of commerce, the origin of national regulations of weights and measures and of prices. Henry III seems to have distinguished himself on some of his journeys by examining the measures on his route, and breaking or burning those which departed from the standards.

National regulation of wage, price, and quality, does not occur often until after the Black Death, and remained the exception rather than the rule until a much later date. The local authorities in each manor or borough acted independently of one another and of the central government. To this statement there are two important exceptions. First, the width of cloth exposed for sale was expected from 1197 onwards to be two ells within the lists; secondly, at least from the reign of Henry II, and possibly earlier, the price of bread was periodically regulated in such a way as to define the just earnings of the baker and his assistants. The price varied of course with changes in the price of wheat. Somewhat later, probably in 1266. similar rules were made in respect to horsecake (made of beans) and beer. Finally we may notice a general prohibition of forestalling, engrossing, and regrating, attributed to the later years of the reign of Henry III.

No less important than the provision of currency and the regulation of weights and measures was the part played by the Crown in providing the necessary legal status for domestic and foreign trade. As regards the former, the King from one point of view stood on the same footing as other great landlords. He could grant to any of his manors such liberties as would permit the growth of trade and handicraft. As a nutter of fact, partly because the King was the greatest landlord in the country, partly because it was to his interest to maintain direct relations with important strongholds and ports, a very large proportion of the towns owed immediate allegiance to the Crown. The growtl of towns, however, though it indirectly helped the rise of national consciousness by $5-(\mathbf{4}+98)$ 
increasing trade, in the first instance meant merely the creation of a type of community more consciously hostile to the rest of the country than the non-trading manor could be. We are therefore more concerned here with those sides of the royal activity which tended to draw together existing municipalities and to smooth the way for trade between them and between manors. Apart from the enforcing of law and order two points require consideration. First, the part played by the Crown in the maintenance of trade routes; second, in the growth of interlocal exchange.

(1) During these centuries the most important trade routes were old Roman or pre-Roman roads and navigable rivers. Coasting trade generally, and in particular the carriage of coal from Newcastle to London, and the ports on the South coast, was only slightly developed at the beginning of the reign of Edward I. " For the maintenance of roads little was done at this or any other time before the eighteenth century. They were probably in much better condition in the Middle Ages than on the eve of the industrial revolution; the work clone on them by the Romans had not yet worn out. The obligation of repairing the roads rested theoretically on the individual parishes; only in the case of bridges were the larger county areas responsible. A parish which neglected its duty might be proceeded against either by officers of the Crown before the King's Bench or by private individuals. In the more serious case of neglect of bridges, any individual amongst those responsible might be sued; but even bridges were often unsafe. Still more important was the need for action by the central government to keep open internal waterways. On the one hand, most of the towns depended for a large part of their trade on the river which ran through them; on the other, many individuals had a direct interest in obstructing them with weirs, diverting their course to turn millwheels, or fouling them with refuse. The Crown was perhaps at times itself an offender in these matters. As the greatest landlord in the country it was likely to be so. In its central capacity, however, it was the authority to which injured interests appealed for protection. Thus an article in Magna Carta grives hope of the destruction of all weirs on Thames. and Medway, and throughout lingland. Whilst there is no reason to suppose that the effectual contributions made by the Crown in these centuries to the maintenance of waterways were great, the general consensus 
that it was matter for regulation by a central anthority and not merely for negotiation or dispute between disconnected interests is important.

(2) As a mediator between divergent interests the Crown clamed the right to prevent explotitation in all its forms. One of the difficulties of development by privilege was the treatment of outsiders by a privileged body. Thus the traders of one town might exact exorbitant tolls from merchants who visitect then. It is true that the interest of the municipality in attracting merchants limited this tendency to exploit the foreigner. But it is evident that the ports. and the towns astride of great trade routes, were in a position if left to their own devices to injure consirlerably places less fortunately situated. Here privilege. whether springing from immemorial custom or royal charter, opposed privilege. By custom the citizens of London seem to have had free right of trade in all parts of the country, and merchants from all over England might reciprocally trade reely in London. Free trade rlid not imply. of course, utter exemption from toll, for certain dues were traditionally levied for upkeep of bridges, maintenance of markets, or merely as taxation. but it did imply freedom from difierential and arbitrary impositions. Similar franchises were, as has been scen, often one main element in the utility to a town of a chartered gild merchant. It is true that a royal charter was often, at least at first, an imperfect substitute for an immemorial right. Apart from difficulties of enforcenent the general rule was that the privileges conferred on one town by a charter were only good in so far as they did not go behind privileges granted to another town at an earlier date. It is probable that intemmicipal treaties of commerce did more to promote freedom of trade than the royal charters. Still the gild merchant was evidently worth paying for ; it gave the traders of a town a basis from which to conduct negotiations.

A very large proportion of interlocal exchange in the twelfth and thirteenth centuries was effected at fairs and markets held in open country or just outside the gates of trims. We find, on the one hand, great annual fairs, such as those at Stourbridge and Winchester, where a whole town of hootls was temporarily erected. where, ar in a town, a special street or quarter was assigned to cach trade. where a particularly adequate peace was preserved by a special 
court administering the law merchant. From such great annual events the series shades down into the tiny agricultural market, held once a week at cross roads for the adjacent manors. These institutions grew naturally from the economic requirements of the people. They were encouraged, like the towns, by the Crown and the aristocracy, partly because their tolls were a valuable source of revenue, partly because trade was especially necessary for the upper ranks of society. "The grants of fairs and markets in the thirteenth century were about 3.300."1

If the Crown had important functions as mediator between English interests, its share in determining the relations between English and foreign traders was still greater. In foreign, as in domestic trade, the political rights, which are a necessary basis of exchange, were secured to the individual merchant as a member of a municipality. and not as belonging to a certain nationality. The merchant of a foreign town who landed in England was dependent on the terms which that town had obtained, and could seldom fall back on rights obtained by treaty between a national sovereign and the English King. But although on the side of the foreigner the city and not the nation was the negotiating unit, England early presented at least some suggestion of a national front. For foreign trade interested both king and aristocracy; it was a valuable source of taxation; it brought desirable luxuries. Hence a constant sale of privileges to the merchants of foreign towns which limited more or less the action of English municipalities. No doubt the need for intervention by the central government was even greater here than as regards the relations between English municipalities. For though the citizens of any one town spoke of the citizens of any other town, whether English or Continental, as foreigners, there is no reason to suppose that they did not in practice treat differently men who spoke English and men who spoke Flemish or Italian.

It is clear that in the thirteenth century towns like Bristol and London, which had a considerable foreign trade, circumscribed very closely the liberty of foreign merchants. It is probable that these restrictions were of old date. Their object was to confine the foreigner to the business of transporting foreign commodities to England and taking away English goods in exchange, and to prevent

'Green, A., "Town life in the Fifteenth Century," Vol. II, p. 26. 
him from securing at the expense of native merchants any miduleman's profit within the country. The foreigner was usually forbidden to stay more than six weeks at a time in the country, and often required to pass that time in the house and under supervision of a burgess. He must sell to and huy from no one fut hurgessess of the town. He must not buy up supplies which they required. He must not sell retail. Superior treatment might be secured, of course, by merchants whose towns had concluded special treaties with the place where they traded. By old usage foreign merchants attended some of the principal fairs, and it is probable that in London they secured a good deal of direct trade with merchants who came thither from other English towns.

The policy of the Crown was to sell licences to indlividuals or to associations giving them more general rights of trade within the country. In so far as they succeeded as a result of such licences in securing trade profits that would otherwise have gone to Englishmen, they presented an object of taxation peculiarly easy to deal with. In so far as this policy was liberal the aristocracy approved and supported it ; it is evident, however, that the more the king took the less would be left for the noble, and it seems probable that the free-trade clause in Magna Carta was framed, as were most of its other clauses, in the interest of the barons. This clause promised "all merchants" security " to go from England and come to England. to stay and travel through England by land or water with the object of purchase or sale " quit of unreasomable tolls. The equilibrium between these divergent policies was exceedingly unstable. As will be seen later, in the fourteenth century the letter of the law was constantly changing. In the twelfth and thirteenth centuries it is probable that the conditions of trade for the foreigner were in fact even less clearly defined.

In early times trade between England and the Netherlands was considerable. Both geographical and racial conditions promoted it, and a natural division of labour developed as a result of the more rapid industrial progress of the Flemish towns. England supplied wool, the raw material of the principal Flemish industry, and got its returns in the finer kinds of cloth. In 1237 we find a general licence for trade granted to Flanders and Hennegau. and the Flemish Hanse of London can be traced back to 1240. This association, in the zenith of its importance, represented the joint 
interests of seventeen towns. Most of these were situated in Flanders, but a few on the French side of the border. in Picardy. Trade with the Italian cities arose out of the transference of money from England to the Pope. Early settlements of Italians are found at the close of the eleventh century. Their exchange business led them naturally to further trade, since the costs of carrying money were saved by the opening of a market for English raw products in Italy. To the merchants of Siena. the men of Lucca and Florence succeeded, and the bankers of the latter town reaped temporarily a great benefit from the exchnsion of the Jews by Edward I. The carrying trade required by the operations of the Florentine merchant was in the thirteenth century in the hands of the Genoese. It is doubtful whether there was any direct trade by sea with the Venetians before the fourteenth century. Venetian products and merchandise reached this country. but they came. at least for the most part, werland across Europe and passed through the hands either of the Flemish or the German Hanse. Trade with Germany is traced back to the tenth century. but for a long time afterwards Cologne was the only German town which secured a privileged position from the English Crown. In 1238 right of trade was granted to Liibeck. and it was under the leadership of this city that the German Hanse was established in London some halfcentury later. Spanish traders appeared in England at the end of the twelfth century, and Portuguese are mentioned in 1274: in neither case. however, was the commerce great. It remains to discuss the considerable trade with France, and especially with those movinces which were governed from England. Gascony, Guienne. and Poitou provided the chief part of the English wine consumption, which was already very considerable in the thirternth century. The same period witnessed a great growth of trade with the North-West provinces, and it has been noticed above that the Flemish Hanse inchuded a number of Picard towns. Lastly, Brittany was a source of supply for important commodities-especially linens and salt. In all these cases most of the carrying was done by foreign ressels. Fishing, however, was carried on all around the coast, and the English traded to Ireland. Scotland and. until driven out by the Germans, to Scandinavia. $1 \mathrm{i}$ is remarkable that even the wine supplies from the English provinces in South-West France arrived in French 
bottoms. English diplomacy was constantly dealing with conflicts betireen Gascon and Spanish ships, but no such conflicts are traceable between English and Spanish. The beginning: of English commercial expansion may. however, be traced back to the thirteenth century. Our merchants at that date were already beginning to dispute the command of the export trade in wool which had been originally built up by Flemings and Italians. An organisation of English merchants tradling to Flanders, certainly existed as early as 1313, and the Staplers at a later date traced back their origin (perhaps erroneously) to the reign of Henry III. Several considerable fortunes were made by English merchints before the close of our present period, amongst them those of Pultney: Rokesley, and Thorne.

The chief sources of revenue at the time of the Conquest were (1) the royal estates, (2) the prerogative. (3) direct taxation, ant (4) indirect taxation-dues upon trade. We shall proceed to consicler the history of each of these resources in turn. We shall then describe the new fiscal expedients.

(1) The royal estates.

The forests provided sport and some food, whilst infractions of forest-law brought in considerable fines. The royal manors provided considerable sums of money as early as Domesday, but the is some evidence that payments in kind contimued to be made as late as the reign of Henry I. The towns yielded at first ground rents, tolls, court fees and fines, and special taxes levied by the sheriff. Sooner or later these miscellaneous revenues were commuted for lump sums paid directly to the exchequer by the municipal authorities and altered from time to time by agreement. The sale of charters was also a fluctuating source of revenue by which considerable sums could be raised under exceptional circumstances.

(2) The general right of the King to take the property of subjects for his own use or that of his court or army is important as containing the embryo of all taxation. In so far as this vague right had crystallised into regular demands from the owners of property or tolls, it is best considered under the head of taxation. But throughout our period the Crown, on its journeys through the country, continued the practice of purreyance. The requisite commissariat was procured from the country traversed either by 
"emption," in which case an arbitrary price was paid by the royal officials for goods seized or transport impounded, or by the simpler "caption." Similarly by "prisage" goods coming into or going out of the country might be taken with or without a payment in compensation which rarely made good the actual loss to the owner.

(3) The Danegeld, the land and property tax of the Saxon period, was retained by the Conqueror, and became under Stephen an anmual land-tax. It was farmed in each county by the sheriff. Under Henry II it seems to have coalesced with the general body of county dues.

(4) At the close of the thirteenth century an "ancient custom" was recognised on wool, wool fells, and leather. The charge on a sack of wool was half-a-mark, on a last of hides one mark. The rect: prisa on wine was one tun taken before and one aft of the mast if the cargo consisted of more than twenty tuns. In some cases the prise was commuted for a money payment. It is probable that a customary percentage was charged on other merchandise also. The Crown constantly added additional charges of an arbitrary nature which prepared the way for the new taxes of the fourteenth century.

The land settlement after the Conquest imposed upon the tenantsin-chief a number of feudal incidents beneficial to the Crown. These formed a source of revenue which we shall follow down to its abandonment at the Restoration. Tenants-in-chief contributed to the king ( 1 ) on occasions of special expense, the knighting of his eldest son, the marriage of his eldest daughter, his ransom, $(b)$ when entering on their tenure, and when alienating land. The king had the wardship of their heirs and heiresses, i.e., enjoyed the revenue of the estate until they came of age or married. and cuuld sell their marriages. They owed also personal service in war at their own charge and provided a number of knights which was defined for each estate. Under Henry I it became general for ecclesiastical temants to commute the military serrice due from their estates. Under Henry II this "scutage" was exacted from all mesne tenants (i.e., tenants of tenants ir capite) who owed military service. This measure was part of a general scheme for substituting a more productive tax for the Danegeld. A "donum" was levied at the same time from the shires, an 
"auxilium" from the towns. A further approximation to a wencral property-tax was achieved by the Saladin tithe in 118s, which foll on the stock and produce of the landowner, and the furniture. money, and stock-in-trade of the townsman. A period of excessively arbitrary direct taxation under Richard I and John leads up to the thirty-second article of Magna Carta: "No scutage or airl shall be imposed in the kingdom except by the common counsel of the realm. except for the purpose of ransoming the king's person, making his first-born son a knight. and marrying his eldest danghter, and the aids for these purposes shall be reasonable in amount." During the remainder of the thinteenth century, anid a variety of expedients-land-tax and tallages of demesne or cities-the plan of requiring a fixed percentage of movables after the fashion set by the Saladin tithe grows steadily in favour. The Jews who came to England in considerable numbers after the Conquest were the last important resource of the Norman and Angevin monarchics. Their legal position was ronghly that of villainage to the king. They were protected in their property and contracts against all other men by the royal courts. Against the king they had no rights at all. The Christian prejudice which enabled them almost to monopolise the business of usury made them valuable instruments. They were used, perhaps unconsciously, as a channel for the taxation of those who came into their power. It may indeed be doubted whether anything near the whole of the taxes imposed on them was passed on in higher rates of interest to their debtors. To secure competitive rates for loans a general change in Christian opinion of usury was necessary. The tallages on the Jews had probably in their economic effects more analogy to those theoretical taxes on rents and monopolies which "stick" whore they are laid.

The main lines of this system may be summarised as follow's. The king drew a great part of his expenditure from quasi-private resources, and much of the work of governing, administering justice, and fighting for the country was performed without special remuneration as incident on the holding of land. Where these resources failed the Crown seized portions of the wealth of the subject as opportunity offered, and it is in this practice that taxation, both direct and indirect, originated. The tendency was to limit the royal power in this matter in two ways - first by insisting on the consent of the powerful classes to such appropriations, second 
by fixing more or less definitely the amounts which might be seized. Although the wealthier classes generally had an evident interest in limiting the royal power, since the first shock of a new tax fell upon them. it is scarcely right to speak of the masses as practically exempt from national taxation. On the one hand, their labour provided the funds which made possible the unpaid services exacted by the Crown from wealth; and. further, the taxes on land and movables, if not immediately transferred from lord to villain by extra tallages. fell at least upon revenues of a quasi-taxational character. The excuse made by Anselm to Rufus in 1095, that he could only make a contribution by grinding his own tenants. is significant. The taxes on property in the thirteenth century usually penetrated very low in the social scale. Thus the fifteenth of 1225 fell on the goods of villains, except their arms. household utensils. and such flesh. fish. drink. hay. and provender as were not for sale. Again. in 1232 the fortieth fell on all movables, exemption being granted to those only whose property was less tha' a quarter of a mark.

The revenue from the royal estates was collected in each county by the sheriff. who farmed from the Crown the right to do so. The Conqueror " sold out his lands as dear as dearest he might, and then some other man came and bid more than the first, and the king granted them to him who offered the larger sum; then came a third and bid yet more, and the king made over the lands to him who offered most of all; and he cared not how iniquitously his sheriffs extorted money from the miserable people. nor how many unlaw ful things they did." 1 The sheriff also collected. but did not farm at a fixed sum, the proceeds of taxation and the law courts, feudal dues. and other sources of revenue in each county. The possibility of exaction by these officers was greatly restricted by the complete substitution of money-rents for payments in kind on the royal manors in the reign of Henry I. A further step in the same direction resulted from the gradual establishment of direct relations between the exchequer and the towns. The problem could not perhaps be solved completely in the existing state of society, and complaints of unjust exaction continued through the thirteenth century. On the other hand, the exchequer developed adequate machinery for

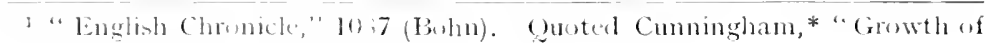
English Industry and commerce," p. 149. 
extracting from the sheriff a full aceount of the moneys which lw was empowered to collect. The assessment of goorls to taxition was sometimes managed by requiring sworn declaration from the owners checked by the opinion of their recighbours: sometimes representative individuals in each district were selected to state the value of each man's goods to royal commissioners. The customs revenue seems to have been collected from very early times by a centralised civil service. In the levying of the customs as of the other taxes, official oppression and exaction were a constant difficulty.

It is evident that the defects in the financial scheme thus outlined were for the most part inevitable. Only a small part of the revenue required could be raised without direct contact between taxpayer and taxgatherer, for the small developinent of trade gave little opportunity for those indirect taxes on commodities which make up such a large proportion of the revenue of modern states. It may indeed be argued with much force that the modern world has gone too far in the opposite direction, with the result that undesirable forms of taxation are acquiesced in because they are not forced on the notice of the payer. In the twelfth and thirteenth centuries, however, the general difficulty of keeping collectors within the limits of their duty was a much more real and serious evil. Again, so few men received any large part of their income in money that it was difficult to measure accurately the wealth of individuals. These evils, and the resultant unpopularity of direct taxation, no doubt made the Crown unduly eager to adopt any method of raising money which avoided it. One cannot but be struck by the persistence of the belief that it is desirable to charge for any right or privilege that individuals are willing to buy, the failure to realise that some privileges ought not to be granted, however much is offered, whilst others ought to be conferred freely in the general interest. This criticism must not. however, be pressed too far. The extent to which taxation restricted economic development was probably very slight as compared with the hindrance wrought by graver defects of social organisation. 



\section{BOOK II \\ THE ENGLISH NATION

$$
\text { 1 272-1603 }
$$





\section{CHAPTER I}

GENERAL SLRVEY

THE fact of nationality is important to economists, though the precise quality of its importance has often been mismderstood. The services of nationalism to the production of wealth are typically illustrated in the convenience of a common rule of the roarl. by agreeing together to observe and enforce certain conventions. individuals can aroid waste of productive energy. The hahit of common action which nationalism fosters promotes such ayreements and preserves them when they are made. They range in mortern communities from the broader principles of individual freedom and property to minute regulations of the terms on which labonr may be utilised to produce wealth or housed when not at work. They may take the form of a collectivist post office. educational system, or water supply: an agreement to pay 10 s. for an article produced at home which could be imported at the cost of 5 s. ; a decision to force trade, whether by diplomacy or arms. on reluctant customers. The extent to which a nation will avail itself of this power, and the wisdom of the conventions which it establishes, are of course alike indeterminate; but there are few. if any cases on record in which the coalescence of smaller social groups into a nation has not coincided with an increase in their material prosperity. In the period on which we are entering, England became a nation with a language, a polity, and a church of its own. At the beginning of the reign of Edward I the fusion of Norman and Saxon elements in the population was incomplete. Royal power and justice bound together districts and towns which had hardly yet felt their common interests. At the end of the sixteenth century a keen sense of national unity pervaded all parts of the country and all classes. The Tudor period is pre-eminently the culminating point of English as distinct from British nationalism. preceded by the loss of Continental possessions. followed ly an ever-increasing complexity of empire. In the ecomomic hintory of England the policy of Burleigh constitutes a great watershert. dividing the old from the new. 
Throughout the period a parallel development of the economic with other national activities may be traced. The cause of the rigid definitions of status, of the firm lines drawn between manor and manor, town and town, in the Middle Ages, was absence of that common sentiment which makes a nation. To understand them it was necessary to refer to those dividing lines which the lack of cosmopolitan sentiment still traces between the nations of the world. When we compare with England as it appears in the hundred rolls the nation which emerged from the shaping hands of Burleigh. we perceive that the cells have combined to form an organic whole, which yet permits to the individual an ampler measure of freedom than was possible for the members of the medieval manor or the medieval town. The whole structure of industry is changed in this transition. In agriculture production for the market has largely increased at the expense of subsistencefarming. Correspondingly in the towns the multiplication of specialised employments has proceeded. But specialised industry has overflowed the towns, and begun to localise itself indifferently in suburbs without their walls or in agricultural districts. These facts indicate an enormous increase of exchange complexity, a greater average distance, both oftimeand place, between producer and consumer. Fence a continued subdivision of trading and productive functions; the growth on the one hand of an army of wage-earners, on the other of a number of capitalist distributors ancentrepreneurs. Into the hands of these last the management of the finance and the control of the foreign trade of the comntry gradually pass. We are prepared to find English speculators opening up connections with distant countries side by side with those who sink money in agricultural production and distribute native manufactures from one end of the country to the other.

These breaches in the isolation of individual manors and towns were made possible by and in turn demanded an increase in the economic functions of the central government. In many matters which could be left to manorial custom or municipal regulation in the twelfth and thirteenth centuries, national treatment cane to be required, or at Jeast national snpervision of the local authority. The need was met by the development of the legislative power of Parliament and the executive and administrative duties of the Justices of the l'eace. Each of these institutions worked with nnore 
or less of friction under the control and direction of the (rown and its immediate advisers. When the control was effective and the direction intelligent, the machine was caprable of admirable results. It is impossible to determine how lat this political madimery was the cause, how far the effect of economic development. though it was plainly each in some measure. On the one liand. Parliament compelled the representatives of rival towns and listricts to search for common interest, and thus promoted the elaboration of national policy. But this result of representative institutions was certainly facilitated by an independent economic development, which opposed the maintenance of local monopolies; and the parallel rconomic development, which was breaking down divisions of status and merging classes, was upon the whole obstructed and probably actually weakened by law and administration.

The course of the movement lies concealed beneath a series of conspicuous accidents throush or within which its motive forces operated. Commencing with the Black Death, in the middle of the fourteenth century, Wre pass to the Hundred Years' Wa Pathe wal between Gancaster and York (3) he enormous expansion of sheepfarmigg, (4he discovery of the New World and the Cape route to the Eask 3 he dissolution of the monasteries, the Gebsement of the currency, and the fall in the value of silver. Each of these events in turn found out weak points in the ofd order, or warpect the development of the new from lines which might otherwise have been followed. After each shock the crumbling fragnents settled to a new equilibrium, soon again to be disturbed. As always in human history, the part played by conscions deliberation and concerted action was small.

The influence of the Black Denth is especially notexorthy in the rural districts. It tumed the slow decay of the manorial system. indid dissolution. It threw the economic system of manorial farming, the social system of customary regulation. into like confusion, and made their permanent maintenance impossible. Every side of the subsequent economic development can be traced back before the disaster, and though progress in each particular was hugely accelerated, the change was not a revolution. But in regarl to customary regulation something comparable to a geological fant perceptibly marks off the period before the plague from the period 
which followed it. In the former period the manorial court is still the centre of interest, in the latter the Crown and Parliament regulate, or attempt to regulate, the main conditions of rural life. The influence of the Black Death in the towns was less important. The blow to their prosperity was severe, but it did not involve any immediate recasting of their economic structure. Rather, as a result of its effect in the rural districts, it brought about an even more rapid development along what had been the main lines of urban progress for some time previously. The increase in agricultural production for the market simply made possible, in the first instance, an increase in the numbers of specialised town traders and craftsmen. The sum of town prosperity was reduced enormously for the moment, individual cities, it may be, were ruined. But the relative importance of town life in the national economy was increased, the ground was cleared for its inchstrial and commercial supremacy in the early years of the fifteenth century. Nor was it necessary for the central government to interfere early with urban self-government.) The municipal authority which was accustomed to meet varying conditions with adaptive regulations was better able to cope with the new difficulties than manorial courts which had to enforce insensibly modified or conservative custom. Moreover, the fact that land in the towns was not a chief instrument of production, meant that the kernel of the labour difficulty in the country did not, save momentarily, exist in the towns. In the country an immensely reduced population was required to cultivate an unchanged quantity of land; in the towns the reduced population could adapt itself rapidly, producing a smaller output to meet a smaller demand.

But the limits of town autonomy were fixed inexorably. So soon as the burgesses became sufficiently entangled in the developing national economy, national regulation was required in town as well as country. As early as 1437 we find a statute which ordered all crafts to submit their ordinances to the approval of the Justices of the Peace. Throughont the second half of the fifteenth century and the first half of the sixteenth century the specific importance of. town life dechines. Each urban group ceases to be separate as a producing or trading unit from the general mass of Englishmen, and the way is prepared for the Elizabethan labour-code which deals I with labour in grarles throughont the nation, treating towns and country on a common basis. This decay of the supremacy of the . 
towns was donbtless accelerated by taxation in the later vears of the war with France and dhuring the civil war, as also by the expenses of fortification during the latter. Its roots, however, lay far cheper. - By the end of the fifteenth century the towns had lost most of that

smpenor sechity minch earter had attracted trade and stinter
craftsmen. It is even possible that excessive regulation tencted now to drive industry outside their walls: it seems certain that many town traders preferred to hire labour in suburbs or comntry districts. The increase of exchange between different parts of the country permitted the producer to live at a distance, not merely from the consumer of his goods, but also from the merchiant capitalist who employed lim.

A corollary to the existence of capitalist employers is the existence of wage-labour. Throughout the first two centuries of our perion we trace its emergence, in agriculture, trade, and inclustry. Its problems fill a great part of the sixteenth century. In the country

A re rillain class of the Middle Ages generated two main classesfeomen and wage-labourers. The latter were the more numerous. In the towns the growth of a wage-earning proletariat, traceable already in the thirteenth century, more and more dominates the situation. Lastly, especially in the sixteenth century, occurred a great development of local industries and bye industries in the country districts, most of which were carried on by wage-labour. / The emergence of the wage-eaming class and of the problems almost inevitably connected with its existence, was complicated by

(1) the Black Death in the fourteenth century, by the increase of sheep) farming between 1450 and 1600 , by the dissolution of the monasteries, 3 Athe debasement of the coinage, the fall in the value of silver. The first of these causes tended to smooth the transition by enabling the class to establish itself at a tolerably ligh level of comfort ancl expenditure, the remainder in various ways tend d to bat down vages, generating misery and discontent.

A tolerably clear comnection can be traced between the derelopment of the "free labourer" 1 and the growth of the problem of pauperism. As was seen earlier, the manorial system provided a degree of discipline for the masses for which the later statutory regulations were an imperfect substitute. In the medieval towns, at least in the larger ones, there was probably always a substratum

\footnotetext{
1 Or, as some prefer to say, "wage slave."
} 
of miserably-paid casual labour, but a large proportion of the population consisted of organised traders and craftsmen who had inclividually some reserve of wealth, and collectively funds for the relief of the unfortunate. The situation was altered greatly by the break up of the manorial system, and the growing dependeuce $\checkmark$ of craftsmen on mant capitalists The accidental circminstances of these comomic traditions contributed, however, as much to the evil as the transitions themselves. The perion of agrarian disturbance which followed the Black Death, thomgh it ended with a material improvement in the position of the masses, bred nomarlic habits, and the arme of tramps was fed a century later by the civil War, and the subsequent dislanding of the predatory retinues. Itost serious of all was the disturbance of population by enclosures for sheep-farming which threw whole villages on to the roads, to roam the comtrysicle as Tagrants or swell the protetariat in the towns. The confiscation of Church lands perthaps, create much pauperism, and ander encumagement to it, but it unctoutedly increased at the moment the pressure of that which existed.

The view is sometimes put forward that the fifteenth and sixteenth centuries were predominantly a selfish age. Thus we read, for instance, of "that remarkable outburst of the spirit of selfsecking which, however we may explain it, was so much more intense and widely prevalent than before, that it strikes us almost as the manifestation of a new economic force." I It is certainly true that contemporary writers, especially in the sixteenth century, made this charge insistently. It is also true that throughont the economic organism we find individuals more eager apparently to make the highest possible profits or ohtain the highest possible wages. There is, however, something to be said on the other side. If our view of melieval England be correct, there is a lark side to the power of co-operation and self-sacrifice which are among the leading characteristies of the mmincipal life of the time. The men of any one town might treat one another tolerably, but how did they treat the stranger? ('an it be maintained seriously that the sleep-famers of the fifternth and sixteenth rentury were as a class mere selfish than the burgesses of an average fown in the thirteenth rutury? It may be argued that they did more harm, bnt they

1 Ashley, "Jeonomic Ilistory," Vol. I, Part 11, p. 49. 
were certainly no more obtuse to other men's interests. In general the gradual removal of the necessity for common defensive artion on the part of small local communities, the gradual increase in the opportunity for anti-social action on the part of individuals distributed through the country, was at least likely to produce an illusion of increasing selfishness. In any case the evidence of contemporary invective is not conchusive. It may point equally to an increase in the evil complained of or to a growing tenderness of conscience on the subject of exils long acquiesced in. Nore often, perhajs, it is due to the latter cause. It signifies that a higher standard is being set up.

The development of thought on cconomic matters was surprisingly small as compared with the changes in economic conditions The European intellect had to sink slowly through upper oceans of theology and politics before it reached the underlying substance of social problems. A great crisis like the peasant's revolt will throw up a couplet anticipatory of the doctrine of natural right. Interest in Greek, combining with humane insight, will produce "Utopia." But, after all, Elizabethan legislation will still be anchored in the medieval doctrine of just price. The tendency of economic forces throughout the period was to break up the sharply. defined estates of the Midllle Iges and substitute for them that infinite individual differentiation which characterises modern England, and still more the United States. But the instinct which had grown up under a different balance of social forces persisted. The ideal of arranging men in grades or classes distinguished clearly and properly from one another maintained itself and was not seriously challenged in its mastery over thought until the influence of Bentham asserted itself. Bentham's philosophy was based, of course, in part on socio-economic developments which had been in progress for centuries. These changes were opposed with more or less vigour at almost every stage by public opinion and the power of the State. This instinctive conservatism had more influence in the long run upon the wage-earners than upon any other class. Special circumstances prevented in England the maintenance of a sharp line between noble and gentleman: and the line between gentleman and trader, though long maintained in social theory, was easily crossed in practice. But in the sixteenth century the "two nations" into which English society will 
shape itself are already firmly emerging. On the one hand are the classes, enjoying a large common measure of economic freedom and self-determination: on the other the masses, in whose position, as defined by the law, there is an element of medieval serfolom, an element of freedom, an element of protection and gurantee.

The wage-earners were both politically and economically weaker than their employers. Th ir work was more easily defined and graded. Their position was more precarious. Each of these considerations conld be urged as excuse or reason for regulating their place in the social scale by statute. And many of the governing class had a personal interest in doing so. Nevertheless it is a mistake to regard the labour legislation of the centuries from Edward III to Elizabeth as an isolated oppression or defence of one class. It is clear that each govermment in turn kept to the ideal of a society in which the position of all classes would be regulated, and that they did what seemed practicable to realise this ideal. " I think," wrote Edward VI, " this country can bear no merchant to have more land

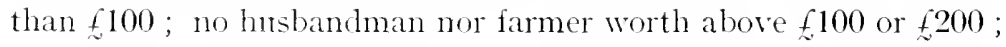
no artificer above 100 marc; no labourer much more than he spendeth;" and again, "This commonwealth may not bear one man to have more than two farms, than one benefice, than 2,000 sheep. and one kind of art to live by. Wherefore as in the body, no part hath too much or ton little, so in a commonwealth ought every part to have ad rictum ct non ad saturitatcm." 1 'The class which was most difficult to deal with, and that which eventually escaped most completely from control, was the constantly increasing number of traters and entreprenenrs. For the hired man a fixed time rate conld be prescribed; for the craftsman a fixed piece rate: for the primitive trader, who was more an operative carrier than a commercial man, prices could be arranged in reference to his class standard and necessary expenses. But in proportion as speculative or organising ability became more and more important it was necessary to leave the reward of the individual speculator or organiser to the profit which he could realise between the price at which he bought and the price at which he sold in open market. It berame ineritable that the weak or unfortmate

\footnotetext{
1 Gurted Cunninghim: " Growth of English lndustry and Commerce," * 1). 560 .
} 
should fail and the strong or fortminate realise wealth, muless the State were prepared to introduce an advanced collectivist experiment, substituting a bureaucratic direction of industry for the play of self-interest.

It is hardly necessary to point out that the State was still too dependent on conservative emotion, too little able to formulate and work out new ideas, for such a remedy to be even contemplated. In default of it statesmen continued to seek in the gild form developed by the Middle Ages the solution of their difficulties. The corporate organisation of different industries undergoes a constant process of readjustment in response partly to pressure from the changing form of industry within, partly to the statesman's demand for order and decency. Misteries, Liveries, Corporations, Companies, Patents, follow one another in bewildering complexity. Far into the succeeding centuries we trace the great trading companies and the privileges of retail shopkeepers in the older towns. Nor was the positive expedient of regulation the only derice adopted: we find also negation - the attempt, time after time, to dam back change. There are constant efforts to check monopolistic practices in wholesale trade, attempts also to limit the control of labour or the use of machinery by wholesale producers. A series of prohibitions of usury leads on to the compromise in the reign of Henry VIII, when a maximum rate of interest was fixed by statute-a special extension of the theory of just price. More drastic still, at least in the letter of the law, was the treatment of the enterprising farmers who increased wool production at the expense of cereals. The evil effects of innovation were here particularly evident. It was not merely a question of the interest of the evicted tenants. The King had a personal interest; for the depopulation of certain areas, e.g., the Isle of Wight, was a serious military danger. Nevertheless the language of complaint goes back to the great criterion of justifiable gain. It was said commonly that merchants or other rich men, instead of sticking to their " honest rocation," were led by greed of gain to speculate in land.

On some technical questions a development of economic thought can be traced, especially on the related subjects of money and foreign trade. We have noticed, already, the legalisation of interest in the reign of Henry VIIl. It is, however, probable that trading on borrowed money remainer a somewhat exceptional practice 
until a much later date. Shakespeare's merchant evidently regards a loan as an exceptional event, and borrows from a Jew, and we shall see that as late as 1640 , eren London merchants deposited their spare money in the Tower, instead of lending it at interest. All forms of lending, however, in which some risk was taken by the lender, probably developed rapidly. The merchant in the fifteenth and sixteenth centuries could usually invest money in a lind of partnership. That is, he could allow another merchant to trade with it on condition of receiving a certain proportion of the profits of the venture or sharing in its loss. The work of Oresme on money, written in 1373, circulated in England. It laid down the principle that the prince ought not to tamper with, or make a profit of, coinage. His clear explanation of the origin of the purchasing power of money forms the starting point for the doctrine that bad money drives out good, which, though associated by tradition with the name of Gresham (a financial adviser of Elizabeth), was known in England and elsewhere much earlier. More important was the gradual elaboration of the mercantile theory of foreign trade and the reaction of this theory on the national tariff. As early as 1381 we find London experts insisting on the duty of the Government so to order the national export and import trade as to maintain the national supply of the precious metals.

The stock, however, of new ideas in legislation was small in proportion to the output of law. The national system was built up very closely upon the pattern of pre-existing custom and bye-lawjust so much of alteration being introduced as the changed circumstances necessitated. We have referred already in general to the attempts to fit the new nationalism into the old theory of just price. It is important to notice how, step by step, the law took back from the enfranclised villain one part or another of his enfranchisement : thrusting him back, not indeed into dependence on one definite person who was his lord, but on lords, that is, employers generally. His freedom of movement, his freedom of placing ont his children, are restricted to the parish in place of the manor. The hours of his labour, the scale of his remmeration are carefully determined. Industry, again, may escape from the town to suburb or conntryside, but it is followerl by gikl regulations embodier in national statutes, just so far altered as the position of the arerage craftsman has sunk to meet the ascending status of the agricultural habourer. 
And, finally, a goodly proportion of the spirit of towin privilexe has gone into l'arliament with representative merchants. Their attitude towards the foreigner is identical with the old town attitule towards outsiders, their policy only so moxlified as is rerpuired by the wider area to be protected, and the larger scale of trute. 


\section{CHAPTER II}

\section{DEVELOPMENT OF NATIONAL POLICY}

THE growth of a national policy in economic matters occupies the whole of our period. Its outlines can be presented most easily by treating separately the following subdivisions-first, the reigns of the first three Edwards and of Richart II; second, the fifteenth century down to the accession of Henry V1I; third, the Tudor momarchy. The first of these periods is marked by steady increase in the scope and complexity of regulation. The legislation of the second adds little of real importance, but contains departures which throw interesting light on the economic development of the country. In the third a shifting mass of experiment, resulting from the pressure of serious social evils, leads to the administration of Burleigh, distinguished alike for its codification of previous chaos, the permanence of some of its work, and in general its intimate and patient handling of evidence and fact.

I. 1272-1399. We have seen that until the reign of Edward I the central govermment undertook only a limited list of duties in connection with the control of economic activities. It aimed at providing sound currency and uniform weights and measures, at regulating the prices of a few articles of universal interest and the wirlth of cloth, and at preventing the cruder forms of fraud and violence. This inactivity was not the result of any aversion from regulation in itself. It was due to the predominantly local character of trade, even where the prolurer did not consume his own output, and to the diffenlty of enforcing the will of the central government in the details of local arministration. The groumd was occtupied by local atsthorities, manorial and municipal. If the manor or the tom were not well governed, it at least did little harm outside its bounclaries.

The legislation of Edward I shows that the central power was stirring and recognising the potential influence of its actions on the ecomonis life of the nation. Wo lind, howerer, during this reign rather vimorous progress within the limits already marked out than the loreaking of new ground. Its most importam measures aim at serming better order and arministration and at providing 
'the basis of security essential to exchange. There are laws to prevent excessire tolls in marliets and towns, and undue exactions by royal officials; to secure safe travelling on the high roads; to police London; to protect the owmers of shipwrecked property. The Fing found that "the prelates and religious persons of the land were grieved many ways, and the people otherwise entreated than they ought to be, and the peace less kept, and the laws less used, and the offenders less punished than they ought to be." He set himself to redress these grievances. His reign, again, was the starting point of better procedure for the collection of debt which benefited both creditor and debtor. All this lies in the direction of making economic development possible rather than regulating its course. And most of the measures are desirable prima facie apart from the possible economic effects. Towards the end of the reign, however, we find two laws which, though of secondary importance in themsclves and easily connceted with earlier precedents, are suggestive of later developments. These are the two Acts of 1299 and 1300 which dealt, the former with the currency, the latter with the trade in precious metals. The statutum de falsa moneta is from one point of view merely one more attempt to improve the quality of the currency; it is, howcver, important as regulating for the first time the export and import of coin. A royal exchange was established at Dover where travellers might obtain English for foreign money in just proportion and vice versâ, and the commonalty in each of a number of ports was ordered to appoint officials to search for and arrest importers of debased foreign coin. In the next year the London " touch," or standard mark for gold and silver, was nationalised by law. "The good towns of England, where any goldsmiths be dwelling. shall be ordered as they of London be, and one shall come from every good town unto London for to be ascertaincd of their touch." Here, again, the old and the new are joined. The measure itself is on the lines of previous attempts to standardise weights and measures for particular commodities throughout the country. But we have here apparently the first instance of the use of the gild system to enforce throughout the country the regulations of the central government. The attitude of Edward I towards foreign merchants was a somewhat liberal version of what had always, in the main, been the policy of the Crown. The carta mercatoria of 1303, "in return for the 
payment of additional customs, abolished all the previous limitations as to the time and place of residence, and as to the persons to whom goods might be sold; and although of the retail sale of most articles the English burgesses were still to retain a monopoly, that of Ispiceries and merceries... was especially permitted to the foreigners." 1 It is possible that Edward I commenced the policy of importing skilled labour from the_Continent to found industries periously non-existent in this country which was dereloped more thoroughly by Edward 111. The beginnings of the Test of England cloth manufacture are ascribed to him on doubtful authority.

The reign of Elward II, as might be expected. shows no important development of whilst administration in many respects declined. There was constant friction. especially in London, between the Cromn and the ongesses on subject of the rights of foreign merchants, the Government maintaining as its ideal the policy of Edward I, but compelled to give ground from time to time. In 1322 however, the foreign merchants were restored to the position granted them in 1303. The most important statutes of the reign were the Act of 1311 , which extended the facilities provided by Edward 1 for the collection of debt and the Act of 1318 excluding victuallers from the more important civic offices. The last seems to have aimed at a better enforcement of the assize of bread and ale. It is interesting as an early instance of the need for national regulation of town life, which became constantly greater.

In the reign of Edward 1 II we find a great increase in the detailed activity of Parliament and new departures in policy of considerable impartance. The general mass can be presented most conveniently under a number of special headings.

(i) Class Organisation.

1) (a) The sumptuary laws of 1336 and 1363 regulated the maximum expenditure of different classes on dress and diet.

(b) From the Black Death onwards a series of measures regulated mages and prices. Of these the most important were the proclamation of 1349 . jsicued a few months after the outbreak of the plague. the confirmatory statute of 1351 , and an amending Act in 1357. The statute of 1351 amed at preventing any rise whether of wages or the price of food as a result of the disturbance caused by the Plack Death.

1 Ashley, "Economic Ilistory," Vol. I, I’t. I, p. 107. 
(ii) Bullion Regulations.

1. The commencement of measures aimi gs at pro iding a supply of bullion is found in the prohibition of export withont licence

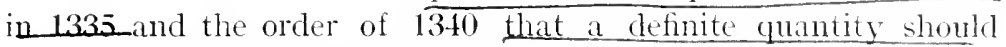
be imported for every sack of wool exported. It does not seem that any conscious theory of the advantage of increase in the amount of coin underlay these proposals; they were framed to prevent an undue reduction by export and to ensure a steady supply for minting.

(iii) Direction of National Industry.

In 1337 a general Act to promote wearing was passed. which ( 1 ) restrained the export of wool and the import of cloth and (b) limited the wearing of clothes made of other materials. It further gave special protection to immigrant weavers who were introduced in considerable numbers during the remainder of the reign. In 1328 and 1353 we have measures which deal with the official grading of cloth exposed for sale. All sides of this policy can be traced to earlier precedents. The protection of the native product goes back to the short-lived experiment of Simon de Montfort (the measure of 1337 was also soon abandoned). The introduction of alien weavers under Edward I has been noticed above. The official grading of cloth goes back at least to the assize of cloth under Richard I. A special officer to administer the assize-the Aulnager-was appointed in the reign of Edward I. The measures of Edward III aimed at providing official marks of quantity and quality in face of the increasing inconvenience of a uniform standard for all cloth.

(iv) Alien Traders.

The struggle between the Crown and the municipalities, especially London, over the position and rights of alien merchants continued. In the early years of the reign the towns regained their old privileges, but these were gradually put aside by the measures of $1335,1343,1351$, and 1353 , at which date the situation was again substantially identical with that created by the cartu mercatoric in 1303. From that date untii the end of the reign the foreign trader was as free as the law could make him.

(v) Restraint of Immoral Gain.

Under this head may be classed the Act of 1351, which forlade merchants to make profit by exchanging coins, and also contained a general pronibition against engrossing in the staple towns. A 
further general prohibition of engrossing was issued in 1353, and the particular cases of the Gascony wine trade and the Yarmouth fishery were dealt with specially.

(vi) A Com Law.

The first Corn I aw-passed in 1361 - shows the increasing importance of commercial agriculture. It aimed at securing cheapness by prohibiting exportation of corn, except to Calais and Gascony.

The increase in mass and scope of legislation observable in this reign continued under Richard II though in the latter case much of it was specially callec for by the chronic disturbances among agricultural labourers and villains which led up to and followed the peasants' revolt of 1381 .

(i) Labour Laws.

The most important - as showing the general direction of policyare the first Vagrancy Act of 1383, the Act of 1388, which fixed maximum wages for agricultural labour, restrained tramps, and prohibited the poorer peasants from diverting their children to non-agricultural emplorments, the Act of 1390 , empowering justices to fix wages within the statutory maxima, and, in the same year, the first game law.

(ii) Bullion Regulation.

The desire to maintain the national supply of bullion was further developed in the Act of 1381 . We read in the preamble of "the great mischief which the realm suffereth, and long hath done, for that gold and silver as well in money, vessel, plate and jewels, as otherwise by exchanges made in diverse manners is carried out of the realm, so that in effect there is none there of left, which thing, if it should longer be suffered, would shortly be for the destruction of the same realm, which God prohibit." 1 The statute was based on information olstained from the officers of the Vint, and the deposition of Richard Aylesbury shows that the mercantilist theory of foreign trade was alrealy taking shape in the minds of experts. "As to the fact that gold and silver come not to England, whilst that which is in England is carried abroarl, . . . if the merchandise exported from England be well and justly governed, the money which is in England will remain, and great plenty of money will cone from abroad. It must be ascertained that no more

1 guoted cunningliam, " Growth of English Industry and commerec," * 1. 395 . 
foreign merchandise come within the realm than the value of the merchandise of this comntry that goes out of the realud." 1

(iii) Navigation.

The fir tarigation. Act, also of 1381 , seems to have been passed on quite general grounds-" to increase the Nary of England, which is now greatly diminisher," and not with a specially econonic object. Its importance, moreover, is purely as marking the trenct of opinion. Its practical results were so unsatisfactory that it was necessary in 1382 to restrict its scope greatly. Instead of a monopoly of the export trade, Enghish ships were to have only a preference in cases when they were "able and sufficient" to do the carrying required.

(iv) Alien Traders.

The period of freedom which had hegun in 1353 cante to an end with the death of Edward III. Fifteen years of fluctuating policy ensued. At last, in 1393, a stable compromise was effected which excluded the foreigners from wholesale trade with one another and from retail trade in any English town, but otherwise left them wide liberties. In the fifteenth century the echoes of the controversy gradually died away. The development of English tracle enterprise rendered the visits of foreign merchants incieasing lunnecessary in some cases, in others provided a basis for reciprocal liberties, whilst the alien merchants who settled in English tomns were encouraged to nationalise thenselres.

(v) Corn Law.

Increased sense of the producer's interest is shom in the Act of 1394 which permits export except to the King's enemies.

II. 1399-1485. The first sixty years of the fifteenth century saw only minor additions made to the policy which had developed down to the death of RichartII. Parliament legislated steadily. but in the main upon the old hines. The fleedon of the peasants was further curtailed by the Act of 1406, which forbade men with incomes of less than $f 1$ a year to apprentice their children in the towns. In 1403 alien importers were ordered to spend all their moneys in buying English wares. The cloth industry and rural employments are alone of sufficient general importance to deniand national regulation. Only in $\mathbf{1 4 5 5}$ we find the first extension of protectionist policy beyond the woollen industry in a prohibition against import

\footnotetext{
1 Translation: for original, see "Rotuli Parliamentorum," III, 127.
} 
of a small class of silk manufactures. We may notice also two measures which indicate the growing need of national control over municipal regulation of industry. The Act of 1437 . which ordered crafts to subinit their ordinances to the Justices of the Peace. instead of merely as hitherto. to the municipal authorities. has been mentioned already. In 1445 comes the first of a series of statutes regulating the Forwich worsted industry.

The reign of Edward IV, on the other hand, is full of vigorous departures. In 1463 protection was granted (a) to agriculture by a prohibition of corn imports when the price was below 6s. Sil. a quarter at the port of arrival (the average price for the decade 1451 60 was $5.6 \frac{1}{2} \mathrm{~d}$. according to Thorold Rogers' calculations). (b) to a long list of mannfactured goods: a Narigation Act, closely resembling that of 1381 , was passed for three years: the trade of the staple was regulated with a view to securing a steady supply of bullion and retaining sufficient wool for the English cloth industry. Two years later $(1+65)$ came a statute containing elaborate regulations for this industry which show " that the trade was carried on alike in town and rural districts . . that mere municipal supervision could no longer prove effective. . . that there was a very complete srstem for the national regulation of the chief industry of the country, ant that this system was chictly enforced by the action of a roval official and his agents." 1 Two other Acts from this reign deserve notice. In 1478 the exportation of bullion was made a felony, and five years later the use of machinery in the cap-making industry was prohibited.

III. 1485-1603. In considering the Tudor period it is not necessary to follow out in detail every development of the policy sketched above. Te shall conclude our chapter by describing how it was handled and applied by Burleigh during the reign of Elizabeth. In the meantime it is only necessary to trace out a few lines of general interest which lead up to the broadest social problems of the Elizab than periơd. wage-labour and pauperism.

(i) I growing hody of legislation marks throughout the period the increasing intervention of the central goremment to control manufacturing industries. It is plain that a two-fold change was in progress. On the other hand. industry in general. and especially the cloth industry, was more and more spreading orer areas beyond

1 Cunningham, "Cirowth of English ludustry and commerce," * p. 436. 
the control of any single centre of production. On the other, the substantial equality between members of the same craft and between allied crafts had completely given way. One craft was falling into economic dependence on another, and within individual crafts superior and inferior classes were establishing themselves. There is a tendency to increase the proportion of low-grate labour by raising the fees for entrance to the craft anct mastership. There is a tendency to increase continually the number of apprentices, throwing them aside when they come out of their time. There is jealousy between capitalists who employ urban and capitalists who employ suburban or rural labour. These developments are too complex for detailed analysis here: they form part of the subject matter of a later chapter. For the present we must be content to say summarily that legislation as regarets industrial employment is steadily tending towards the point at which a common cole for agricultural and industrial labour will be possible.

(ii) A series of labour statutes and poor laws mores towards the same point. In the former there was not much change. The Act of 1495 was practically a re-enactment of earlier measures. The same is true of the Act of $\mathbf{1 5 1 4}$. The maximum wages prescribed are raised to bring legislation into accordance with facts. Some attention was paid to combinations of rictuallers to raise prices; and combinations of artisans were also prohibited. A severe law was specially directed against trade-mion action in 1549. On the other hand, the treatment of the memployed gradually gained in discrimination. This morement was common in the sixteenth century to most countries in Western Europe. Roman Catholics and reformers agreed in the need for better treatment. of the problem. So far in England the impotent poor had been left to charity, whilst the Act of Richard II against vagrants was too severe. The penalty for vagrancy was reduced in 1495 to three nights in the stoclis, and still further curtailed in 1503. In 1495 an attempt at discrimination was made by ordering certain classes, poor scholars, soldiers, and sailors, to carry authoritative letters when on tramp. In 1531 this principle was extended. Justices of the Peace were empowered to license impotent persons to beg in defined districts. In 1536 an attempt was made to raise funds in every parish and to provide relief or employment. Contributions (in theory voluntary) were to be collected each sunday by $7-(1495)$ 
the churchwardens. The Act contained clauses against begging and indiscriminate charity. Considered as a whole, it must be regarded as the starting point of the English poor-law. The situation was complicated, as noticed above, by the dissolution of the monasteries: the effect, however, of the confiscation of gild funds in 1547 is not now believed to have been so serious as early investigators supposed.

The reign of Edward VI commenced with an Act of extraordinary severity. It was withdrawn in 1550 when the Act of 1536 was revived almost unchanged.

The increasing sense of social responsibility for misery is shown also in measures which deal with two of the chief causes of misery during the sixteenth century, the increase in sheep-farming at the expense of tillage, and the rise in prices. The laws which deal with the former will be considered in a later chapter. From 1489 onwards it was constantly in the mind of the government, and Wolsey in particular devoted great attention to it. As regards the latter there was. until the reign of Elizabeth. too much tendency to connect the rise in the cost of living with the increasing control of production and sale by a capitalist minority. The general feeling was akin to that which is gathering force against the trust movement in America at the present time. We find accordingly attempts to prevent the enhancement of price by combinations and corners.

It is important to remember that the general policy of the government in the reigns of Henry VIII and Edward VI created social problems at a pace which outran all possible remedy by legislation. The debasement of the coinage. the land speculation which followed on the wasteful use of confiscated property, the extravagant expenditure generally conld not but increase the ineritable hardships of a period of transition. And some superficially well-meaning laws were cmptied of their force by sale of licences to evade them. Thus the attempt of Wolsey to bring land back into cultivation was turned into an engine for raising money. The sheep-farmers paid fines for permission to continue on their own course. Even for Henry Yll ne more can be claimed than the negative merit of avoiding extravasant expenditure. And his determination to acrmulate treasure led to exactions from towns and indiviluals, which were cortainly not calenlated to stimulate conomic enterprise. In many respects the interval between the accession of 
Henry VII and that of Elizabeth resembles the period from 1760 to 1830 . In each case great economic transitions are in progress. In each case they are complicated by avoidable and irrational evils. In each the misery of the mass of the people atrances rapilly. And similarly the reign of Elizabeth offers a pate parallel to the democratic reconstruction of society whose basis appears to have been laid since the parliamentary reform of 1832 .

The general aims of Elizabeth's government were to maintain the naval and military power of the population, ancl to provide a decent and secure subsistence for all Englishmen. They conceived these aims as mutually interdependent ; a well-nourished. regularly employed, and prosperous population seemed one main condition of national power. Their methods were to lay down in permanent measures what seemed a framework for safety and stability, and to treat watchfully all minor dangers or departures from the equilibrium either by executive intervention or by temporary enactments. Under the former head we may class the reform of the coinage, the statute of artificers, the poor-law code, the planting of new industries, the gradual extension of protection. Among temporary and elastic measures come the assessment of wages by the justices, provided for in the statute of artificers, and the regulation of the price and sale of corn in times of dearth. No definite line can be drawn between the two, but it is usually easy to decide to which class a particular event belongs. The machinery used consisted generally of the justices, or parliament, or both. It was managed by the Privy Council, in which Burleigh was the predominant influence from the beginning of the reign until his teath in 1598. His papers show clearly that he was a slogging, methodical worker. His intellect was not first rate, and this fact, combiner with his serious industry, makes him a valuable interpreter of his time.

The Statute of Artificers (1563) was intended to lay down the general conditions of employment for agricultural and industrial wage-earners. It was desired to strike a reasonable balance between the somewhat conflicting interests of employers. wage-earners, and consumers-reasonable that is by the standards of contemporary common sense. The still predominantly agricultural character of the community is shown in the neglect for the training of the agricultural labourer; it is assumed that the proper place for men who 
have had no special training is " the land." and in fact. " all ablebodied men became liable to serve as agricultural labourers, and could be compelled to do so, unless they could prove that they were exempt from the obligation." 1 All artificers, on the other hand, whether in urban or rural districts, were required to have served a seven years apprenticeship, the object being apparently (a) to secure good workmanship, (b) to lessen umemployment by preventing employers from going outside the ranks of trained men. In a number of specified trades, presumably those which showed a tendency for the apprenticeship system to be perverted into a means of obtaining cheap labour, masters were compelled to employ one journeyman for every three apprentices. I further effort to prevent irregularity of employment is the clause which " insisted that labourers should be hired by the year." Reasonable wages, as before remarked, were to be assessed in all cases by the Justice of the Peace, account being had of changes in the cost of living.

It remained to lay down the general lines on which those who would not or could not work, or who failed to obtain employment, should be treated. Experiments in this matter continued throughout the realm, and concluded with the great codifying statutes of 1597 and 1601. The Acts of 1563 and 1572 developed the principle of compulsory contributions. The latter provided machinery for levying a definite sum from each housebolder. The appointment of overseers to distribute relief dates also from 1572. In 1576 provision wats made to set the able-bodied to work in corporate and market towns, on raw materials publicly provided. The legislation of 1597 was based upon an elaborate consideration of all obtainable evidence as to the facts of the problem and the success or failure of experiments which had been tried locally. As eventually codified at the end of the century, the poor-law purported to distinguish between (a) impotent, (b) genuine unemployed, (c) idle poor, and to treat each class differently. The impotent were to be cared for lumancly if old, if young to be maintained and taught a trate. Work was to be fomd under tolerable conditions for the gennine memployed. The idle were to be disciplined with a view to their eventual restoration to the liealthy body of the nation.

To facilitate the working of the general system, and to increase

"Comningham, " Cirowth of English Industry and Commerce," ** p. 29. 
the strength of the productive power of the nation, the Government was anxious to "keep work in the country" and to develop new industries, more especially those, whether new or old, which had a bearing on national security. A considerable part of the work of the Privy Council consisted in planning and executing measures of this kind. Tillage was encouraged with a view to increasing a desirable form of employment and making the country independent of foreign food. The observance of Lent was ordered to maintain the fishing industry in 1559, and in 1563 the importation of foreign cod and ling was prohibited. Several measures were passed to prevent the importation of competing foreign manufactures. Burleigh held firmly the doctrine of the balance of trade. "It is manifest that nothyng robbeth the reahm of England, but whan moore marchandisees is brought into the realme than is carryed furth. . . . The remedy herof is by all pollycyes to abridg the use of such forrayn commoditiees as be not necessary for us." 1 Enghish shipping was encouraged in 1559 by the imposition of differential duties on the lading of foreign vessels. But considerable exemptions were granted to established trades, and it is evident that more benefit was judged likely to result from direct encouragement for the fishing industry and from the opening of new lines of trade than from attempts to divert existing traffic into English bottoms. The grant or sale of patents to individuals or companies, giving them the monopoly of certain industries, was used first to encourage new industries or methods, second to introduce stable organisation into existing industries, third as a means to raise revenue. Efforts were made to exploit the mineral resources of the country, to estahlish the manufacture of ordnance and control in the public interest that of gunpowder. Other grants aimed at promoting the manufacture of window-glass, salt, starch, and many other articles of general use. No very clear line seems to have been drawn between grants which purported to develop an industry, where the patentee proposed either to bring a new process into use or to import skilled labour from abroad, and grants which merely placed in the hands of individuals the power to tax, under cover of regulation, an existing industry. The most recent investigation of the patent system, by Mr. Price, seems to show that its disadvantages outweighed its

1 Quoted Cunningham : "Growth of English Intustry and Commerce," ** p. 71 . 
merits, a view which is shared by Mr. Unwin. Dr. Cunningham, and Mrs. Tomn-Knowles appear to hold the contrary opinion, at least as regards the patents granted in the first half of the reign. At the close of the reign the Govermment admitted that the popular complaints, as voiced in Parliament, had considerable foundation in fact. The general aim of the government to secure stability by detailed regulation is seen very clearly in the management of the com trade. The Privy Council kept its finger on the pulse of production and consumption, now enlarging facilities for sale in one part of the country or another, now contracting them, now compelling sale at a reasonable price. The object was to secure such an average level of production as would prevent famine in years when the harvest failed. - 1

It will be seen that the duties undertaken by Elizabethan statesmen demanded an exceedingly high level of integrity, industry, and tact in the central authority-conditions which were fulfilled to an extraordinary extent during this reign, despite such aberrations as wasteful grants of monopoly patents to incompetent favourites. There was, however, little in the history of the country, more particularly in the history of the fifteenth and sixteenth centuries, to suggest that the standard would be maintained permanently, and we find no effort made to establish an educational system or permanent bureaucratic departments which might maintain sound traditions against the inevitably fluctuating wisdom of the monarchy. As little was any attempt made to secure efficiency among the Justices of the Peace apart from the wisdom of the Crown in selecting individuals. These defects were doubtless inevitable; but recognition of then will smooth the way for an understanding of the breakdown of the system in the seventeenth century. The ideal Engish nation which occupied the imagination of Burleigh wats a drilled and disciplined industrial army in which each man did what he was ordered to do by the central govermment, or stood in the place allotted to him by birth. Of the force of individual initiative, the beneficial stimulus of competition he held litte conception, for the excellent reason that what existed of each was mere leaven in a lomp of solid conservatism. To the modern economist the enterprise of traders and sheep-farmers in the sixteenth century is an carly manifestation of forces which have been at the root of economic progress. To contemporaries these 
beginnings seemed largely antisocial or selfish. Some of their immediate products were evidently bad. If the sixteenth century was too hasty to impute evil, too incapable of imagining possible good results, it at least lacked the modern conventions which blunt men's minds to the intrinsic quality of actions, if they are believed to be inevitable, or to produce a balance of good.

When we view the legislation of these centuries as a whole, we find in it the development and gradual application to the nation of ideas which had been implicit in the local organisation of earlier times. The requirements of the new unit, the nation, are not identical with the requirements of the older units, manorial and municipal ; but the spirit in which trade is manipulated to supply national needs of butlion or ships, is identical with the spirit which had regulated the freedom of individual burgesses in the supposed interest of the borough community, and in many instances an almost direct transference of methor from the city to the nation can be traced. The exclusion, for instance, of foreign manufactures is substantially identical with the burgess' local monopolies. The restrictions on the sale of raw materials to the foreigner recall municipal care for securing to the citizen a right of pre-emption in all goods which were exposed in the town market. The national regulations of cloth-making, the one industry which had altogether outgrown local control, liept in view the objects which inspired contemporary municipal regulation of other industries, so far as this was compatible with its more complicated organisation. In some cases even local gilds were still used to enforce the regulations, standing in much the same relation to the central government as their predecessors had stood to the municipality. The labour statutes in the rural districts must be regarded from the same point of view; some of their harshest provisions may be riewed, not as an additional burden imposed upon the peasants, but as incidents in the process by which the central govermment took over the decaying powers of the manorial court. The national regulations which compelled them to work, which tied them to a particular village, which excluded them from non-agricultural employment simply replace in a form adapted to altered circumstances the secular restrictions of villainage. But, although the legislation of the period was thus rooted in the past, the changes made were important. The substitution of national for local regulation, of legal 
discipline for class servitude, mark important stages on the road to freedom. What Parliament did for the whole country could be undone for the whole country by Parliament. The hundred heads of the hydra were gathered into one.

The fact that the nursing age of the mercantile system witnessed in the removal of local restrictions a great development towards free-trade enterprise, should comnt for much in our riew of the period. We are in danger of underestimating its importance because it was underestimated by contemporaries. In the fourteenth and fifteenth centuries we already find traces of that curious exaggeration of the importance of foreign trade which makes up one of the most interesting chapters in political psychology. The language of the first great protective statute in 1463 is indicative of this product of developing nationalism. Owing to the import of wares, "fully wrought and ready made to sale," the "artificers cannot live by their misteries and occupations as they have done in times past, but divers of them, as well householders as hirelings, and other servants and apprentices in great number be this day unoceupied and do hardly live in great misery, poverty, and need." Was it really the foreigner who was responsible for this evil? The failure of this and later statutes prohibiting importation to cure the erils complained of, is not conclusive against this view; for legislation was not continuous, and was often evaded. But the quantitative insignificance of the foreign trade of the country at this time, combined with our knowledge of the industrial rearrangement which was in progress, incline us to suspect that the root of the evil was growth of exchange between different parts of Engiand rather than growth of exchange between England and other countries. Twenty-six years earlier it had already been necessary to subordinate the crafts to the officials of the national govermment, and from this time forward we find accmulating evidence of the breakdown of the industrial isolation of each town mit. In the sixteenth century it was possible to frame labour statutes for industrial wage-earners comparable in their scope to the primarily rural labour-code constructed in the century that followed on the Black Death.

The phrase "nercantile system" was used at ove of the body of legislation whose genesis we have traced. It is established by high authority, and cannot mislead if regarded simply as a convenient 
technical term. It is, however, well to remember that the legislation in question was neither essentially " mercantile " nor particularly "systematic" in any usual sense of those words. The merchants of medieval towns imbibed from their environment a certain lias in favour of privilege, monopoly and regulation. But merchants are not naturally disposed either towards restrictom or towarls laisser faire, and the merchant magnates whose advice uncloubtedly contributed enormously towards framing the laws of the fifteenth century, though they inherited a general bias from their predecessors, were already developing some of that turn of mind towards free competition whose growth has led modern Englishmen to suppose that a "trader" is naturally a "free-trader." The system was not systematic in the strict sense. Its parts can be referred to nogeneral principle other than that of attaining the best compromise possible between public and private interests as those interests were understood at the time. Bacon, writing of a later development of the system, said that Henry VII had "bowed the ancient policy of the realm from consideration of plenty to consideration of power," and some writers see in this ant thesis between "power" and "plenty" as alternative national objectives a possibility of reducing to system the policy of Edward I on the one hand, that of his successors the "mercantilists" on the other. There are serious objections to this view. The word "power" must be construed in a very elastic sense before it can be made to cover the varied aims of Burleigh. Still more difficult is it to find in "plenty" an even tolerably adequate description of the aims of Edward I.

It is interesting that whilst the originator of the phrase drew the dividing line at the accession of Henry V1I, modern historian: who have borrowed it have no difficulty in showing that the legislation of that king was in no sense original, and refer the origin of the system to the reign of Richard II. The analysis of legislation presented above will show that no clear line can be drawn between the aims and methods of the advisers of Richard II and those of Edward III. That the phenomenon with which we are dealing is one of growth and not of revolution is made clear, moreover, by the absence of broad divisions of opinion on questions economic. Differences, or supposed differences, of interest indeed existed, and we may expect minor fluctuations of policy as the balance 
of power inclines towards the towns or the landowners. or is poised fimly in the hands of a leader of men. But no such difference of theory as separates extrene adrocates of laisser faire from extreme adrocates of State-intervention. or again extreme adrocates of opulence from extreme adrocates of power existed in the fourteenth century. Men were united in a common perception of certain truths. a common ignorance of others. They agreed that an industry must be planted before it will grow. that bullion must come into the country before it can be used as money. that great disturbances of wages and prices are an evil, and so on. On the other hand. they were inclined to neglect all the secondary effects of their actions. and to accept without much thought the first explanation of a difficulty which suggested itself. Their policies were the ineritable product of minds that have a traditional bias in favour of privilege and regulation. and have not rigorous ly examined the theories by which they interpret economic phenomena. The normal European mind continues to be of this type down to our own day, and exceptions to the norm were rare before the end of the eighteenth century.

A further important point should be noted. The modern conception that when a new law interferes with actions which have hitherto been legal. compensation must be paid to rested interests. or at least that change must be introduced gradually, was almost nonexistent. If an individual chose to do things which common sense or his neighbour= could tell him were opposed to the general interest, he dirl them at his own risk. The law would neither spare nor compenate him. though he might of course be sufficiently strong to influence or evade legislation. The modem view (which is. of course. still neither generally accepted nor carried to its logical conclusion) seems to be the result of two causes. First. a feeling of social responsibility for the existence of evil which increasingly shames men out of throwing the cost of its cure upon minorities. Secondly: a really greater division of opinion as to what is desirable. which compels majoritie to purchase the assent of minorities.

Finally, it is worth remembering that we do not know accurately. to what extent any one of these laws was enforced. That they were felt to be ineffectual in many cates is clear from the frequent re-enatment at short intervals of time of practically identical measures. The general attitule of society towards the law was 
influenced inevitably by the difficulty of administration. The two-handed engine stood ready to strike the evil doer-in theory -but men were used to seeing the evil-doer esealpe. Persistence in ineffectual legislation does not imply in our ancestors either gross obtuseness to facts or lack of humour. For the laws, and especially their lengthy and often argumentative preambles, discharged educational functions which are now performed by the publication of debates and official docuinents, by the platform, and by the Press. There was hardly another way in which society, or a section of it, could express itself. So laws multiplied upon the statute books, and at least, one might have sail, not much harm was done. The most serious charge which can be advanced is that of a cumulative repression of experiment and change, operating partly by direct repression of the new, but still more by steady support and encouragement of conservative prejudice. We may instance the attempts to prevent the rise of wages in the fourteenth and fifteenth centuries, the occasional prohibition of new mechanical devices, and the interference with large scale production in the sixteenth century. It is impossible to judge the indirect evil done in this way. It may have deferred advance for centuries. It may have been negligible. It is, however. worth noting that in ail probability the government in these and other cases really mitigated repression by standing between conservatism and incipient change as a buffer. It is worth considering whether the statutes of labour did not save the nation from a class war ten times more serious than the Peasants' Revolt, though in appearance they merely voiced the interests of a ruling class. Here and elsewhere legislation served as a safety-valve for conservative emotion, and conservatism outside Parliament did not have everything its own way. 


\title{
EHAPTER III
}

\author{
TRANSITION IN AGRICULTURE
}

Ix discussing the manorial system we devoted some space to the forces which were already undermining it in the thirteenth century. We traced in particular the beginnings of the substitution of money for produce and labour-rents, of the leasehold system, of exchange between individuals within the manorial community, and between manor and town. We have now to describe the final victory of these forces over the old order and to analyse the new equilibrium which had been reached by the end of the sixteenth century. The resistant power of the manorial system, and especially of those elements in it which were bound up with the strip division of arable, was great. In the ordinary course of erents change was slow, for though such experiments as made possible increased division of labour or encouraged tenant or labourer to greater exertion were likely in most cases to perpetuate themselves, they were not very rapidly imitated on other estates. It required a considerable shock to throw the old system out of gear, and set men upon an eager search for more profitable organisation, and no such shock was delivered until the middle of the fourteenth century.

In 1349 the Black Death reached England, and in that and the two succeeding years killed off a large proportion of the people. It returned at frequent intervals for more than a centmry afterwards, but no subsequent visitation was so deadly as the first. Contemporaries formed exaggerated estimates of the mortality, asserting in some cases that nine-tenths of the popmlation died. The trend of modern opinion is to accept a reduction of between one-third and one-half, or in numbers from something over 4,000,c00 to something over 2,500,000. For the latter figure some authority can be elaimed-resting on the results of the poll-tax in 1377. The former is conjectural, but is supported by stucty of the rise in the number of presentations to benefices during the plague years. The return of the plague at intervals, and the persistency of labour trouble during the next century make it improbable that the loss was made good rapilly. At the end of the sixteenth century the population is supposed to have been about $5,000,000$, 
and contemporaries believed that a rapid progress was taking place in the reign of Elizabetl. That the resluction in numbers was sufficient to affect enormously the intensity of the demand for land in rural districts is evident from the legislation of the fourteenth century. The reduction of the labour supply as compared with the area under cultivation applied that slock to the manorial system which hastened its decay.

The reduction in the labour supply affected all the manorial lords injuriously, either directly or indirectly. Where the system of farming the demesne by a bailiff existed the injury was direct. If the chief work were done by labour service the reduction in the number of labouring tenants had to be made good in some way, and it was difficult to prevent the terms of the tenures from being made more easy. Where the labour service had been commuted for money-rents and the demesne was worked by hired labour the difficulty would be more immediate-less money would come in and higher wages would be necessary. Indirectly the same causes would reduce the letting value of the demesne or other land where the leasehold system had been adopted. There would, on the one hand, be more land on the market and fewer competitors for it, on the other, the tenants having themselves to pay more in wages, would be less able to afford the old rent. It is therefore a mistake to see in the Black Death a cause which made the old system of demesne-farming unprofitable as compared with the leasehold system; indeed, it is likely that the friction against competition was stronger under the older system, and that for the moment the effects showed themselves more completely in regard to leaseholds which had fallen vacant than in regard to bailiff-management of the demesne. The blow dealt to the manorial system was of a subtler kind. The general reduction in the value of land, however managed, tended to jolt landlords out of conservatism and to make them adopt methods which would have equally paid them better before the disaster. Necessity opened their eyes to the advantage of new principles which had long been gradually winning their way, and in place of a slow development we find a rapid transition. Of course, also, the snapping of traditional ties by death made a change of system easier.

The elements of this transition gronped theniselves round two points, $(a)$ the disposition of the demesne land, and $(b)$ the 
disposition of the tenurial labour-dues. The two questions are not, it is true, disconnected, for the changes in either case were largely interdependent. It is, however, convenient to analyse them separately.

(a) The demesne land. In the years immediately following on the Black Death the system of bailiff-management gave way generally to the land and stock lease whose nature was explained above. It is evident that, given the conditions created by the plague, this was the line of least resistance. The land was there with farm-buildings, stock and tools. It was impossible to work it at a profit on the old system. The natural course was for the lord to let the demesne to any man who would guarantee him a larger money-income than the old system would now provide. It is plausible to suppose that in many cases the new lessee had been bailiff under the old system. Working the land in his own interest, subject to a fixed rent, he might work harder himself and use his local knowledge in beating up labour, so as to provide some income for the lork, and yet considerably better his own position. That the plan was profitable to the new class of lessees seems clear from the rapidity with which the stock and implements became their property. In general. it seems, the land and stock lease system lasted only fifty or sixty years from the date of its adoption. By that time the tenant had usually accumulated sufficient capital to work the farm. The system thus gave way to that kind of lease which is still characteristic of English agriculture, where the landlord supplies land and buildings and the permanent improvements, the tenant all else. It is worth noting that a somewhat similar development occured in regard to the manorial mills. Here also three stages may be traced corresponding to the bailiff-management, land and stock, and modern lease. In the first the mill is worked in the interest of the hord by a servant at a fixed income. In the second a fixed rent is paid for the mill and plant. In the third the owneship of the plant has passed to the lessee.

(b) The labour dues. Dearth of labour and the decline of bailiffmanagement both contributed in the long rm to the commutation of labour-dues and the final risappearance of rillainage; but here again it camos be argued that the Black Death necessitated the rhange" eren if the growth of the leasehold system be taken into account. The lorel's power over his villains was in law elastic 
enough to allow him to sell their labour precisely as he solet the use of the cattle on the denesne farm. In practice the clainge of system made the continued use of labour-rents on the demesne lanel intolerable. The tenant, on the one hand, whowas prohucing for the market, woukl prefer to buy labour as he wanted it - to escape in fact from the meshes of custom. From the labourer's point of riew there must have been often a sentimental difference between performing labour-dues under the direction of his bord's agent, and assisting his lord's tenant to make a profit. The machinery of the manorial court would eridently work less smoothly. Apart from surh general considerations the long-maintained lisbour dearth put the labourer in a position to exert considerable pressure if he wished his lored to accept a monetary commutation. For though the law and the executive were on the side of the lord, the conntry eried out for workers, and if the villain chose to flit, he found little difficulty in placing himself at his own terms on another lorel's lanel. The risk that he would be traced was small, and if he were, the legal process of reclaiming him was slow and difficult.

The explanation put forward by Thorolu Rogers of the comnection between the Black Death and the Peasants' Revolt of 1381 has been in great part abandoned in the light of subsequent investigation. He maintained that the commutation of labour-dues harl been almost completed long before the Black Death; and he conjectured that the lords, finding the money payments less valualle as wages rose. attempted to enforce a return throughout the conntry to the old labour-dnes, and that the peasants revolted against this attempt. It is plain that this account will not square with the facts. On the one hand, uncommuted labour-rlues were still of cardinal importance in the manorial system on the eve of the plague; on the other, that event in many districts stimulated commutation. It is clear that in the Peasants' Revolt it was the insurgent villains who proposed change, the lords who demanded conservation of, or return to the status quo ante 1349 . Apart from the pressure of taxation, the underlving canse of the ontbreak of 1381 seems to have Theen as follows. : The decrease in the population had so disturbed the equilibrinm between the supply of land and the lemand for it that competitive forces were working to improve the prosition of the villains and generally of all tenants at the expense of their hords. Villains who wished to utilise this advantage found themselves 
obstructed by their legal and customary dependence upon their loris. They sought to turn this obstacle in various ways. Some demanded that the legal disabilities of the villain should be removed, others sought to destroy the manorial records which the lorrls opposet to the demand for competitive rents, others claimed that a maximum rent for land should be fixed by law. Under great local diversity we find everywhere traces of the fact that customary arrangements no longer corresponded even approximately to competitive tentencies. Burdens which had been borne without complaint when they were felt to be inevitable, or rather. when no facts existed which suggested that they were alterable, began to be felt as oppressive and unreasonable. The conception of just price is abandoned forthwith by the party to whom its application is now no more than a hindrance, and its place is usurped by clear foreshadowings of egalitarian doctrine. The primitive life in which Atam delved and Eve span, and where class differences did not exist, is evidently the state of nature beheld through Christian spectacles. The whole episode is instructive of the nature of conservative custom, resistant like glass to small momenta, shattered into fragments by one decisive blow.

The status of villainage survivet for more than two centuries after 1381 , and not as a mere legal form. In the early part of the sixteenth century Fitzherbert lamented its continuance in some parts of the comntry. Later, Elizabeth took measures to abolish it on the estates of the Crown. It was, however, in the sixteenth century mowe than at strvival. The forces which were undermining it in the thirteenth century were quickened by the Black Denth and gathered strength as time went on. The growing use of Tand for production for the market involved the spread of more arlaptable labour arrangements than those of the manorial system. Sale of the proxhuct made it easy to pay wages. Lease of the demesne mate commutation of labontues mone than ever desirable. Thove all, as agriculture was more and more directed celiberately to satisfy demand, the problems of the entrepreneur required that simplification which the wage system permits. It was impossible to continue to define accurately low murh and what labour a serf shoulel perform, when the land to which he was at tawed was used according to the three-field system in one generation, turned into a sheep-run 
in the next. and converted, it might be, to mixed huslomulng of a variable character in the third.

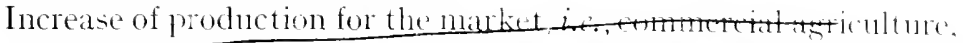

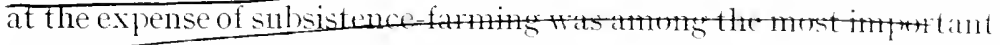
restits of the growth of the leasehold srstem. The existence of at market is indeed a precedent to the payment of money-rents since the money can be obtained only by sale of part of the procluce, and we have seen that by the end of the thirteenth century some considerable progress had been made in this direction. But as long as the manorial system was maintained, it may be doubted whether the market was often the main objective of agriculture. In some districts, it is true, especially in the North, gruat tracts of land were early (leroted to commercial sheep-grazing, and it is probable that the greater proportion of the surplus of leatherbeyond what was required for rural consumption-came from a few pastoral districts. It must be remembered, howerer, that even at the present day small farmers often consume an appreciable proportion of their produce, and that down to the industrial revolution they consumed most of it. In the Nidelle Ages alnost the only large farms were the manorial demesnes, and these in many cases produced what was required for the lord's household in the first place and only marketed any surplus which remained. When the large tenant-farm and the commutation of labour-clues became common, the market ceased to be merety a place for the sale of surplus produce, and began slowly to react 11 pon supply-determining what should be produced, and stimulating economic progress. Evidence of the growth of commercial agriculture accummlates from the second half of the fourteenth century onwaris. The corn trade of the country is regulated first (1361) in the interest of consumers, afterwards (139t and later) more and more decisively in the interest of producers. The profits of wool-production cause an increase in sheep-raising at the expense of cereal-farming. In the sixteenth century the market was so recognised as a predominant influence that protection of the corn producer could be adrocated in order to check the speculative farmers' too exclusive pre-occupation with wool.

The influence of the market, which thus began to emerge, has remained the controlling force in English agriculture down to the present time. From the fourteenth century onvards every

$8 \quad(\mathbf{r}+98)$ 
important shift of srstem or organisation can be explained by reference to changes in demand. The first important shift of this nature was that created by the growing demand for woot in the fourtexth, the fiffeenth, and the first half of the sixteenth centuries. In the later half of the period indicated, there was a strong tendency to increase the area devoted to sheep-rearing by retrenching the arable. It was not until the concluding decades of the reign of Elizabeth that the first signs of a reaction were seen, and moneyed men began to sink capital with the object of increasing the supply of corn.

The interest of the English in sheep-raising was a byword both at home and abroad before the middle of the fifteenth century. but it does not appear that the industry up to that date had interfered much witl cereal-farming. From 1450 onwards, for more than a century, statesmen and economic experts were concened with serious social problems which resulted from displacement of tillage. It may be supposed that the sheep-runs of the twelfth anel thirteenth century were established on land which had not up to that time been in use, and that the reduction of the poptulation in the middle of the fourteenth century left room for the peaceable extension of the inclustry for another humbed years. Where all, or nearly all, the inhahitants of a village perished. the turning of the land into a sheep-run was ahnost the only way in which the lord could derive an income from his land. In face of the general demand for labour and for cultivating tenants, re-establishment of open-field tillage must have been almost impossible. Is time went on it became evident that sheep-raising left a larger margin of profit than other agricultural enterprises. The population, and with it the demank for food. increased slowly. the worllen

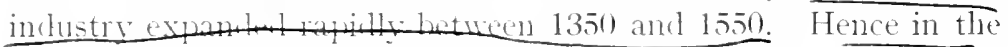
second balf af the difterenth century the moblem of still further

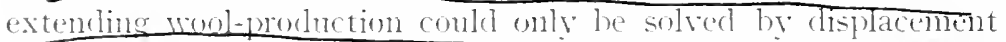
of tillage, and we reach the beginning of the lirst great encostme

morement.

Whe have seen earlier that the system of open-field agricuiture

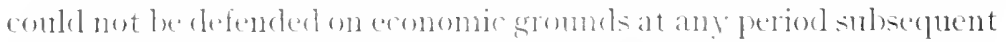
to the Noman concunest, lut that it prestesed an enormons power of resisting minor motives to change. The temlencies which hat feen working in the thirteenth century towards the creation of 
several property were stimulated no doubt hy the generat derelopment of commercial agriculture, which was caused hy the Black Death. There is, howerer, no reason to suppose that the prospect of any moderate increase of profit would have been sufficient to break down the conservative force of custom. An exceptional and extraordinary stimulus was required, and was provided by the change from arable to sheep pasture. Even this in all probability would have been inadequate had the population, which was disturbed when a village became a sheep-run, been fully compensated. The peculiar legal relationship which existed in the fifteenth century between the lord and the majority of his tenants, enabled the lord who made this change to secure not merely any extra procluct which the new method might extract, but, inasmuch as far less labour was needed, a larger proportion of the gross product. Contemporaries, indeed, would have denied that extra product was obtained at all. They saw that the wealth produced from a given area was less under the new system than under the old, although, inasmuch as a larger proportion went to the lord, it paid him to make a change detrimental to the nation as a whole. It seems probable that this was in many cases a true account-so far. Its defect is, of course, that it allows nothing for the product of the labour displaced. Much of that, no doubt, in the first instance was merely thrown out of employment. It could be argued, however, that the average mass of unemptoyment could not be permanently increased in this way, except in so far as the sufferers bred a class of pauper labour of low efficiency. stamina, and character. But this exception is important. Looking at the question all round, it seems clear that modern writers who speak of the better use of national resources, take too optimistic a view. Apart from the question of equity, the industrial system was still too little elastic to absorb rapidly the labour which was set adrift, and much of it in consequence depreciated with disastrous results, both social and economic.

On the other hand, so much at least of good was contained in the movement, the over large areas the cumbrous open-field system was abandoned, and the way cleared for a rational development of agricultural technique. The spirit of change, which was genterated by the extension of sheep-runs, spread at the same time to other forms of agricultural production. Side by side with enclosure for 
sheep-farming, though doubtless on a much smaller scale, enclosure for mixed agriculture went on. It attracted less notice from contemporaries because it produced no evil, and it seems to be impossible to estimate quantitatively how much of the enclosing was of this satisfactory kind. Fitzherbert, in the final chapter of his "Boke of Surveyinge" (pub. 1523), enlarges on the profits which would result from the equitable dirision betwcen lord and tenants of the land of an open-field village. The change wonld give to each cultivator a small number of several fields adjoining one another, and of convenient size, mstead of his numerous scattered strips and rights of common. The better utilisation of land and management of cattle which this change would permit are clearly explained. It is, indeed, possible that even this kind of enclosing bore hardly upon the cotters who would not be in a position to claim compensation for their loss of common rights. The analogous enclosures which were made at the end of the eighteenth century, and during the first half of the nineteenth, had this disadvantage. Still the changes could be approved as likely to benefit the great majority of those affected by it. Hence, when the State began to interest itself in the enclosure movement and to take measures to check its evil results, a clear distinction was drawn between such enclosure as was beneficial to the commonweal and that which involved the pulling down of houses of husbandry, and the conversion of land from tillage to pasture.

When the object of enclosure was an extension of sheep-farming, the results were more or less serious, according to the extent to which the lord orer-rode the interests of his tenants. We may consider several degrees.

(1) Enclosure of the Demesne. This would not affect the tenants seriously, provided it was equitably managed. It is true that they. would lose their old right of pasture over the demesne arable at times when it was not under crop, but in cases where the lord similarly resigned his common rights over their arable, the advantage might even be on their side. It should be noted, however, that the wage-eaming cotters would suffer from a recluction in the demand for their Tabour, much of which depended upon the arable taming of the temesne.

(2) The effects hecame more serious when the lord extended his conclosire to the woods and waste. The Statute of Merton, in 
the thirteenth century, recognised the right of the lords to anclose their waste, woods and pastures, provided that ther left sufficient pasture for the free tenants. It a later date this general protection seems to have been extended to villain tenements. But it is evident (and was pointed out by Fitzherbert), that in defining what was sufficient the lord would be at a considerable arlvantage. Such enclosures seem to have made it difficult for many of the tenants to keep enough stock to work their arable, and combined with reduction in the demand for labour to have made the position of the cotters untenable.

(3) But the lords often went further wen than this, and enciosed not only the demesne, wastes, woods, and pastures, but alco all the arable land that was not held freely. This implied, of course, the displacement without compensation of the cultivating tenants, and a consequent additional diminution in the demand for the labour of the cotters How far the lords had a legal right to do this is a question which belongs to legal rather than to economic listory. It is certain that the right was exercised extensively during a period of about a hundred years-more or less-between 1450 and 1550 . Remedial legislation begins with the Act of 1489 " against pulling down of tounes." It is perhaps significant that the tenor of this Act was rather to make such enclosing unprofitable to the encloser than to assert its illegality.

In 1514 the question was dealt with by a Royal Proclamation. In the two following years further legislation was passerl; and in 1517 a commission was appointed which collected information on the extent of the evil. The reports of this Commission for some counties still remain, and fully bear out the impression made upon contemporaries by the transition. As a result of the inquiry of 1517 the Crown took proceedings against a large number of enclosers. It appears, however, to have been content to extract revenue from them by levying fines. We may conclude that such a large proportion of the governing class in the country were intercsted in the matter, that no drastic remedy was politically practicable.

It is important to notice that the movement was well adranced at a date considerably before the dissolution of the monasteries. The eridence which remains from the Commission of 1517 shows that ecclesiastical hodies had been by no means backwards in enclosing as compared with the laity. It is, however, probable that the 
dispersal of the monastic estates accelerated the process in so far as they passed into the hands of adventurers or speculators who were anxious for quick returns. Nor should the fact of the destruction of the feudal aristocracy in the fifteenth century be overlooked. A very large proportion of the estates of the lay nobility, as well as of the estates of the Church, changed hands during the course of the enclosure movement. The new nohility created by the Tudors was largely recruited from burgess families who brought into the business of landlordship, at least for the time being, an element of unsentimental greed.

Fruitless attempts to check enclosure by legislation continued until the movement slackened in the closing decades of Elizabeth's reign. It appears that the period of serious social detriment enced earlier; and the enclosures between 1550 and 1600 seem to have been made, gencrally speaking, with tolerable equity towards the tenants. Whatever the law on the subject may have been a century earlier, the courts had now developed protection for the rights of customary holders. A copy of an entry in the rolls of the manorial courts was admitted by the royal justice in proof of title; and it seems probable that this develoment of protection for the customary tenants was the cause of the slackening of the enclosure movement. It would eviclently increase greatly the resisting power of mere conservatism against equitable and beneficial no less than against unjust and disastrous change. We may, it is true, explain the close of the extension of sheep-runs as a result of growth of population and consecpuent increased demand for food. Is has been remarked earlier, moneyed men at the close of Elizabeth's reign were beginning to fincl it profitable to sink money in arable farming, a fact which points to the conclusion that there was no longer any differential atvantage in sheep-rearing. It appears, however, that heneficial enclosures, coually with the destruction of villages, became far less common at the close of the sixteenth century. The movement never ceased altogether, but perthaps one.third of the country were still unenclosed in the middle of the eighteenth century.

The history of the legal recognition of the rights of customary tenants has a further interest beyond its connection with the curcosures. If some bords were rearly to erict their tenants without compensation, others a fortiori would impose on them, in defiance of custom, the highest rents which competition could exact. 
They would be encouraged by the land hunger of tenants evicted elsewhere, and by the general increase of terminable leases which resulted from the new method of treating the demesne. The question did not of course emerge until more than a century after the Black Death. Up to that time there was land in plenty: the difficulty was to get cultivating tenants; but trom the second half of the fifteenth century onwards, as the poptulation increased and sheep farming trenched more and more on arable, the letting value of the customary holdings rose steadily. Is soon as this happened, a lord - especially if he were of the new business-like type-would be led to compare the difference between the income which he derived from that part of the estate which was leased on terminable agreements, and that which came in from customary quit-rents. The attempt would often be made to reduce the latter to the condition of the former, and it is clear that the same process occurred here as in regard to the evictions. So long as the royal courts either did not or could not protect customary holders, they were liable to be and often were rack-rented, and came to occupy a position indistinguishable from that of leasehold tenants. This occurred, for instance, in the famous case of the farm of Latimer's father, a case which was mentioned by his son, not as an exception, but as an example of a widespread practice. The remedy discovered by the royal courts for uncompensated eviction put an end to this process also by firmly establishing the legal right of the customary tenant in his holding subject to payment of the customary quit-rent. Even so a loophole was left which enabled a lord to resume the holding on the death of his tenant. The heir was liable to pay a fine on beginning his tenancy, and the custom was that such fine should be reasonable. But as late as $159+$ the King's Bench held " that after the demand of a fine by the lord and the refusal of the tenant to pay, though the fine might be unreasonable, the estate would be forfeited." 1 The Court of Common Pleas opposed this view, and the King's Bench afterwards abandoned it. In the seventeenth century " two years' value was settled as the limit of reason." 2 It seems likely that but for the enormous social evil of uncompensated eviction this development would not have taken place. The lords would probably have reduced all but

1 Ashley, "Economic History," Vol. I, Pt. II, p. 283.

2 Ibid., p. $2 \$ 4$. 
frechold tenants to the position of the tenants who held on terminable agreements.

The growing profits of trade in the fifteenth and sixteenth centuries hegan that process of the manufacture of gentle families by landlordship which has continued to our own day. In the medieval period it was comparatively rare for the lord of a manor to spend any considerable part of the year in residence at his estate. Apart from other considerations, he usually owned a large number of manors, and could spare but a short anmual visit for each. The dispersal of aristocratic and ecclesiastical property was the opportunity of the rising commercial middle-class: and the resident squire is already, in sixteenth-century England, the focus of rural life. As Justice of the Peace he gradually takes over more and more of the powers of the decaying manorial courts. Is the parliamentary govermment of the fourteenth century is submerged beneath the Tudor personal monarchy, so local self-government becomes monarchical, and remains so until far on in the nineteenth century. Below the squire, the most important classes are large tenant-famers and yeomen with small freeholds and copyholds-the yeomen being the more numerous. It the bottom comes a considerable class of agricultural labourers, many of whom, perhaps most, had an acre or two of land and, where commons remained, free grazing rights. In much of this chapter we have heen occupied in tracing the growth of production for the market. Here it is well to emphasise the fact that its importance was rather qualitative than quantitative. 1t was the sign and momentum of change: it was not in bulk the most important part of rural life. The yeomen and the labouring families must still have supplied much of their wants by direct production. Yet ren for them the market becomes more and more important, and not the agricultural market merely: tor an increasing percentage of the poores class added to their income log manufaturing byes-industries.

As the manorial system, with its discipline and constraint for the inclivirlual, disappeatred, it was replaced in some measure, as has been inclicated atrearly, hy a series of statutes which regulated the terms of employment of agricultural labourers and rumal artisans. The first of these was the statute of 1351, which ordered all able-bodied persoms below the age of sixty, whether they were free or bond, to acept agrionlumal employment at the wages which had been paid 
in 1346, unless they were merchants, regularly-employed craftsmen, proprietors, or engaged in cultirating their own land. The conception that the labourer should not be free to sell his labour in any market or for any price he pleased, continued to inspire legislation throughout our present periorl. We have seen already that it appeared unmodified in the statute of artificers, although the purpose of that Act was a much wider measure of social juitice and expediency than is discoverable in the laws of the fourteenth century. 


\section{CH.IITER IV}

\section{CLLAIXATIOA AND DECAY OF LRBAN INFLLENCE}

THE changes which have heen described in the rural districts harl inevitahly a great influence upon the development of the towns. We have seen that the requirements of the aristocracy gave the first impulse to industrial and commercial specialisation, that social conditions promoted the concentration of the first traders and craftsmen in walled and privileged communities, and that thromghout the twelfth and thirteenth centuries every step which was taken towards the break-up of manorial isolation resulted in increased exchange between each town centre and the surrounding country. For nearly a hundred rears after the Black Death the agricultural transition contimuer to influence the towns in the same way. Similar crafts and similar commercial operations developed in each town to supply the needs of the surrounding combry. This century (from 1350-1450) is the time during which the gild system developed its fullest and most vigorous form. Inexorable influences prevented its prolongation. On the one hand, the steady widening of the market gave capitalism more and more power, on the other, modification of social conditions removed the causes which had confined many industries to fortified places. The gild institution continued to develop for another century ; it preserved a certain importance down to the reign of Anne; but from 1450 onwards we find a derline in the specific importance of town life in the national economy, and often. it would seem, a quantitative loss of prosperity in the individual towns. Even the earlier period of growing importance presents its own complexities. It seems evident that town life was a more considerable force in the middle of the fifteenth century than at the begimning of the reign of Edward I ; yet it may be questioned whether in many cases the population, if not also the aggregate wealtl, was as great at the latter date as it had been at the former. In all the larger towns in the fomteenth century seciety was wrestling already with the social diffoulties which are causer by complex industrial organisation. In the zenith of town influence we know too much of the wealth of individual merchants, too little of the condition of the masses, to assert that this rather 
than another was the period of maximum urban prosperity. Of town influence during the period indicated there is evidence enough. Already in the reign of Edward III the nobility began to be recruited from the ranks of the merchants. In the graduated Poll-Tax of 1379 the Lord Mayor of London is assessed as the equal of Earls, Bishops, and Nitred Abbots: substantial merchants and the mayors of small towns, are assessed at various rates corresponding to those paid by landed squires and the small abbeys. Throughout the fifteenth century the political importance of the towns is considerable. In 1461 Edward IV is guest of Canynges, the Bristol merchant. It is true that from 1432 onwards l'arliament in some cases remitted the contribution payable by towns to the fifteenth and tenth tax. This practice, however, was due partly to recognition of the fact that the relative wealth of individual towns had altered partly to the real decay of a minority. Mrs. Green has shown, moreover, in the particular case of Coventry that a municipality might be in arrears with its ferm, and have no attachable property to speak of, at a time when individual gilds within it possessed considerable corporate wealth. ${ }^{1}$ In the sixteenth century an impression of urban decline was produced by the fact that many of the towns failed undoubtedly to keep pace with the general industrial progress of the country. They contributed also at least their fair share to the increase of pauperism, though in this connection their continued vitality was shown in a series of municipal experiments in poorrelief upon which the Elizabethan legislators drew frcely. The impression of decay is accentuated by the evident anxiety of the Government to stem the tendency of manufacturing industries to desert the towns for the country. Finally it seems clear that as capitalism ripened and as the clear lines of demarcation between town and country faded, the wealthiest citizens ceased in part at least to feel identity of interest with the town where their business centred. It became increasingly difficult to induce substantial men to undertake the burdens of municipal govermment. Often they ceased to reside in the towns, even when they continued to trade there. When they had made money they invested it in lanci and turned themselves into squires. As the quality of municipal government declined, so the gild-form travelled further from its original intention. Sometimes it became a retailers' combination,

\footnotetext{
1Green, A. : "Town Life in the 15th Century," Vol. II, p. 216.
} 
sometimes an emasculated trade-union, carrying out the regulations of the Central Government but incapable of forming or enforcing a conscious policy: most often a mere shell within which the newly-formed industrial classes operated.

The reign of Edward I marks the period at which the trans ion from gilil merchant to specialised crafts, whose features have been outlined in an earlier chapter, became common in English towns. Before Edward I, although a considerable degree of specialisation alreaty existed and had in some cases produced already independent organisations - for instance the lorimers' gild, which is found in London in 1261-yet, taking the country as a whole, the gild merchant is the normal institution. In the fourteenth century, on the other hatml, the gild merchant has smk into obscurity: where it continues to exist it is merely a formal survival. The transition was eviclently encouraged in many cases by the municipal grovernment, though there can never have been much distinction in fact between their views and those of the leading traders and craftsmen. It was also encouraged by Parliament-though here again much of Parliament represented municipalities. It seems to have been pretty wenerally agreed that a more elaborate method of controlling trade and industry than the gild merchant was now requirexl. We may also conjectme that as freedom of exchange between different parts of the country and different towns increased the need was no bonger felt for a special organisation combined in which all the trate and production of the town could present a common front to the citizens of other places. One sicle of the work of the gila merchant in the thirtenth century became progressively less needed, for the other side it became progressively unfitted. Hence the transition to separate organisations which might be either brotght into tourh, where they existed, with the municipal authority, or emontraged and called into existence where they were wanting. The transition was not effected without friction, for the municipalities wisherl dlese new organtisations to be strictly subordinated to their contend, and as has leen seen earlier, a few special gibls aldraty existed which hat bomelit from the (rown peculiar privileges. In lomelon the struggele cance to an enel in 1300 when the wearers grild was finally subjerterl to the control of the mayor atut alkemens. There wats, indeed, some tromble later in the reign of tilwarl 111, as a result of the immigration of fifemish weavers, 
but it died away after they had formed themselves into a gild of the normal type beneath the juriscliction of the authorities. In other towns such disputes continued, or more probably took place, at a later date. As late as 1376 we find the Commons complaining that the existence of privileged misteries in many horoughs imperled the mayor in the execution of his duties. In any case by the end of the fourteenth century the position in most towns was as follows. The municipal authority, the mayor, port-reeve, or bailiff, and the councillors framed, or at least approved, all economic regulations. Their court was predominant in econonic rlisputes, and their executive functions were also considerable. But in each trade or craft, if it occupied only a score of men, a separate organisation existed, whose officers drafted regulations for their mistery, and if the draft were approved by the authorities, executed its terms, inspecting the shops and houses of all members, prosecuting defaulters in the municipal court, and so on. Further. the majority of these crafts possessed some corporate property, and levied contributions, the proceeds of which were devoted to common expenditure at festivals, and formed also a mutual insurance fund. A natural scheme for the development of our subject now presents itself. We shall proceed to examine (1) the economic functions of the civic authorities (2) the organisation of the crafts.

(1) The civic authorities.

We may distinguish their economic functions as falling within one or other of two classes, according as they give rise to ( $l$ ) regulation of production and exchange, (b) communal action.

(a) Regulation.

They framed, as has been seen, bye-laws the general object of which was to enforce the principle of just price-more particularly to prevent fraud on the consumer, monopolistic practices, and usury, and to secure to the producer or trader his reasonable standard of living. They protected, so far as they could, the local monopolies of retailer and craftsman, attempted to check the cruder forms of commercial deceit-sale by false measures and weights, or sale of adulterated or damaged goods. This involved, or seemed to involve, a stereotyping in many cases of methods of production which aimed at securing a definite quality of product. For instance, it might be ordained that a particular article should be made at particular places only, viz., the houses or workshops of the local craftsmen 
where inspection was easy: by daylight only, since candlework is apt to be faulty, and also since honest men will work only in the light of day. It might also involve the use of specified kinds of raw material, the use of particular processes, the standardising of the output. The terms upon which a man might work at a particular craft required also, as it seemed, definition in the interest of consumers. As to-day we insist on examinations for doctors and lawyers, and are inclined to insist on a Lniversity degree for clergymen, so in the fifteenth century no craftsman could set up in indepentence unless his shill were guaranteed by experienced masters. Both wages and prices were also nomally regulated. Trade did not admit of quite such intimate control as handicraft, though even here we find cases where the cost of carriage, the price of the article at the place whence it is bought, the fair profit of the tracker are carefully estimated and a local just price built up on these foundations. More generally attention was centred on preventing monopolistic advantage accruing either to seller or buyer. There were rules to prevent artificial manipulation of the market, such as prohibition of purchase with a view to resale in the same market, puinishment of bogus sales at a pretended price. whether high or low, insistence on publicity of all dealings. There were also regulations to promote equitable distribution of the available supply between all who needed a commodity. such as the right of any burgess to claim a share in a bargain concluded by another hurges with a stranger. There was aho. of course, repression of usiry.

It will be plain that all this is the application in cletail of the theory of just price, and much is of comse anticipated in the less complex economic casuistry of the gilel merchant. It should, however, be staterl once for all that the theory was derived from the farts, or what secmed to be the facts, of industrial life. There was no logical application of a priori conclusions. business ethics arose by a process of a natural selection, by the survival of those expedients which were thonght to work well. Of course, in julging What workes well mesn were inthenced both by natmral ethics and ly christan doctrine. hut molern historians rightly call attention to the degree in which the syotem wats empiricat. There is, howerer, at danger of exaggeration in the opposite direction. We are not to condemn these regulations from the ilea that they were pedantic 
applications of an incomplete if not absolutely fallacious economic theory; but neither if we are sensible sliall we accept them blindly because practical men approved of them. For practical men are no more infallible than economists. They may misread even the immediate effects of intervention, and they may even be expected to misread or neglect all its indirect results. It cannot be pointed out too insistently that our historical data are inadequate to prove in any particular case that this or that regulation had, on balance, good or bad results. The issues are too complex: the evidence too scanty and suspect of unconscious or deliberate bias. General considerations seem to show, (1) that in nearly all cases the direct effects were likely to be good, (2) that in very many cases some at least of the indirect effects were likely to be bad, (3) that there was often serious risk of abuse and perversion of what in itself was well meant if not expedient, (4) that evasion would be frequent.

The direct effects of honest attempts to prevent flaud, adulteration, and overcharge were likely to be good. At the present day a considerable amount of such regulation exists amid general approval; there is even a demand for more than we get; it is not doubtful that we should do more if business were as simple and fraud as crude as it was then. A strong case can be made, however, for the view that some of the methods adopted to protect the consumer were likely indirectly to do very serious harm. The most vulnerable points are $(a)$ the regulation of production, and $(b)$ the regulation of admission to the craft. It is clear that the former might delay improvement in technique, the latter create a quasi-hereditary trade monopoly. It may be urged, on the other hand, that neither result could seem probable at the time when these practices grew up. The conception of a craft was a certain, almost unchanging, body of knowledge, transferable by teaching; the idea of expansion was by succession of sons or relatives; both conception and idea rooted in the facts of the situation. This very stability of fact which tended to conceal the slow beginnings of progress was, it must be admitted, peculiarly liable to lead men to neglect the possibility of improvement, and it may be argued that an unnecessary hostility to change arose out of this neglect whose effects were appreciable later on. It would be admitted, I think, that this happened in many countries on the Continent, and though its effects were certainly less marked 
in England. it would be rash to suppose them non-existent. Applications of the themry of just price to eraftsmen's wages and prices may be approvect in a large proportion of cases. They were at least not more likely to work badly than such partial competition as the life of the period permitted. The same may be said in general of the regulation of wholesale trade. The wholesale merchant found plenty of scope in interlocal commerce, and industry was not so far developed as to stand in need of organised future markets. On the other hand, the numberless local markets, only imperfectly communicating with one another, opened an endless prospect of sucessul rigs and coners. As regards the repression of usury not much sympathy need be wasted on the usurers who actually suffered; but the failure to extend to loan capital the ordinary theory of just price rested upon serious theoretical confusions. and probably tended in practice to accentuate the evil which it was desired to eradicate. One may hold this view with the more confidence since. as time went on, it became the view of practical men. We have noted earlier that in the sixteenth century at tempts to prevent any price being paid for the mere use of money gave way to attempts to prevent exorbitant charges strictly analogous to wher contemporary and earlier applications of the theory of just price.

When we proceed to inquire how far these regulations were abused or evated we reach an accumulation of particular instances which defy gentralisation. Some writers neglect this aspect of the matter, or content themselves with a merely l'latonic recognitim of it. Others assume that regulation was used normally as a weapon of oppersion by the strong against the weak, and evaded hy the influential whenerer that course suted their convenience. The history of the economic development of England in these centuries seems to prove (1) that town regulation was unable permanently to resist the larget changes of industrial structure, just as parliamentary statutes conk not entirely prevent the rise of Wages betwen 1350 and 1450 , w the progress of enclosing for sheepruns: (2) that the wealier party in an incustrial conflict of interests habitually soltght its remerly in regulation, and certaing did not perceje the hact, if it were a fact, that regulation was always manipulated in the hong run are at to adrantige the stronger.

To execute their regulations the municipalities used in most 
cases the individual crafts themselves, retaining, howerer, ahmost invariably the judicial and punitive functions. The markets, however, were controlled by special officials, and in regard to commodities which were largely consumed within the town itself, especially food, drink, and fuel, it was early perceired that independent inspection was necessary. The assize of bread and ale, for instance, was administered either by the mayor himself or by a special officer. From the fourteenth to the sixteenth century it was even forbicklen by statute that a victualler should hold important municipal office. In addition to its ordinary judicial work the municipal authority settled by arbitration disputes arising between citizens in so far as they were not already corered by its published regulations.

(b) Communal action.

Traces of the origin of town life in village communities of cultivators were long important. The arable land was in most cases enclosed at an early date, but pastures open to the cattle of all burgesses long remained. The number which each might keep was clearly defined by custom. More interesting is the fact that some towns traded as units. It is uncertain how widely the practice prevailed, but it can be traced at Chester and Liverpool in the sixteenth century. The account of what happened at Liverpool suggests that the practice may have grown out of the general principle in town life, which gave each burgess a right to share in bargains concluded by his fellow-citizens. Imports were offered first to "the Mayor and town." If the municipality deciled on purchase, a price was offered. If the importers did not like it, they made the best terms they could, or went elsewhere. Such a srstem was evidently well adapted to dealing in commodities which arrived by the shipload-in considerable quantities. The seller would be in a more or less monopolistic position. If the municipality constituted itself a ring, it could enforce a fair price, or even an unfair price. advantageous to itself. It might pay the importer to sell the goods cheaper if he could thereby aroid the labour of individual chaffering and manage the unloading cheaply, or leave it to be done by the purchasing municipality. Some towns went further than this; they appear as units in the fisheries and the Gascon wine trade, and it is possible that quasi-municipal fleets were the origin of some of the companies of Adventurers. Such enterprises have evidently more analogy to modern partnership 
than to modern municipal trading. The advantages were shared out on straightforward principles. The cargo, or purchase, was divided among the merchants in proportion to their status, and each man sold his portion to his own individual advantage. It is strictly analogous to the use of the common pastures. The municipality makes no common profit or loss, which it may use in "relief of rates " or make good by an "additional halfpenny." We hear, however, also of very considerable public works undertaken by the municipality. Fortifications, of course, were normally a first charge. Very little road-construction was done, though sometimes a wealthy citizen woukd leave a bequest for this purpose. Occasionally some great public work would be performed-a canal dug, a harbour enlarged-by forced labour of the whole community. Indertakings which required the temporary concentration of considerable capital were beyond the scope of private enterprise. Individual capital was locked up and conk not easily be mobilised. Hence in all probability the common municipal practice of providing reserves of com against times of scarcity. Private trade in corn was primarily local: in the event of local supply failing, consumers might have to wait long before the resultant rise in prices would attract supplies from distant markets. Sinilarly the normal enterprise of private trate combl not be trusted to provide for exceptional consumption such as was occasioned at Canterbury in 1420, when the Jubilee collected a hundred thousand pilgrims, and the corporation took special measures to secure an adequate supply of povisions and was able to prevent a rise in prices. In the case of lomlon we can follow ont in detail the process by which the city, from special measures in famine vears, went on to provide permanent town granaries, a municipal mill and bakchouse, and a municipal brewery.

This practice, which developed in the sixteenth century, was one side of the municipal treatment of porerty. We have seen already that munipal experiments served as a basis for the general poorlaw legistation of the Elizabethan periogl. The poblem of poverty in the latger towns was complicated then at now by the difficulty of distingushing between foluntare and insoluntary unemployment. Mmoingal experinent amed generally (1) at a classification of the momployml, (2) at discrimmating treatment, relief for the impotent, work for the willing, correction for the idle, (3) at the 
prevention of wasteful charity and the raising of a common fund. The first compulsory levy in relief of poverty seems to have been the London loan in 1520. The first poor rate was the London fifteenth in 1547. The matter constantly exercised the authorities, especially when Ridley was bishop (1550-3). Christ's Hospital was organised as an asylum for poor children, Bridewell as a house of correction for sturdy vagabonds, Bedlam as a place of restraint for lunatics, St. Bartholomew's and St. Thomas' for the sick and aged. This activity of the city resulted in the rescue from the confiscations of a certain proportion of the old endowments and charities and a better administration of the funds whose control was thus centralised. The surveying and licensing of beggars, the provision of relief work, the establishment of a house of correction were common to many towns. The difficulty, of course, was to provide work which did not compete with existing free labour. A partial remedy was provided by placing the marketing of goods made by pauper labour in the hands of the trade organisations. Still harder was it to secure a tradition of sound administration. In spite of brilliant exceptions the conditions precedent to corruption were already deeply rooted in municipal govermment. The towns had entered on that period of decadence, which lasted till the recommencement of town democracy in 1835 .

(2) The organisation of the crafts.

The starting point of craft-organisation was found in the multiplication of separate small businesses in a number of trades and handicrafts. In the larger towns, at least in London, it was probably complicated by the pre-existence of some large commercial concerns, but in most cases no appreciable difference of economic status seems to have separated the average master-trader from the average master-craftsman. There was, no doubt, always some difference between the size of one business and another. A thirteenth-century assize of bread contemplates master bakers who employ one or two labourers and two or three boys. Here we have already an "establishment" which in many cases would require more labour than could be provided by the craftsman's family. Often we find that a craftsman and his assistant work side by side. Often the craftsman depends solely upon his own labours, and that of the son whom he is training to take his place, with perhaps occasional help from his wife. In trade the business must often 
have grown beyond what a single family could manage. It would depend npon the conditions of particular industries whether the assistant labomrers, normally passed on in time to the rank of independent mastership, secured a subordinate degree of organisation as professimal joumermen, or remained mere casual or unskilled labour.

The conditions which make such an organisation of industry posible may be defined clearly. First, the amount of capital reguired must be so small as compared with the earning power of labour that a skilled worker can easily acquire enough to start for limself; second, there must be little roon for the exercise of special ability in procuring the raw materials: third, the difficulty of marketing the product must also be small. These conditions were fulfilled in the industries and trades of most English towns in the fourteenth and great part of the fifteenth century. The raw materials came for the most part from the surrounding country. They were brought to market either by the producers themselves or by small carrying traders. Any craftsman could purchase them there, and special care was taken to prevent the market being cornered. Sale, again, was comparatively a simple matter. The craftsman either made to his customer's order, or sold his wares in open market to the ultimate consumer, or to small distributing perlars and merchants. The capital required was simple and inexpensive.

These conditions would be preserved so long as (a) it remained diffecult to distribute most commodities over wirle areas, (b) the growth of population was slow. The former is the more important consideration, since the litter would not lead necessarily to more than douliration of businesses. the ir average size remaining the same, provichel that large seale production were not havened by mechanical improvenuents. It is probably true that the population of the combtry wastill smaller at the end of the fifteenthe century than it

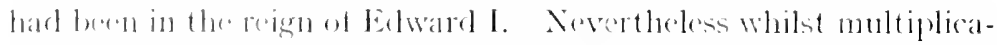
tion of inderendent craftsmen is the keynote of the former period, the latter is distinguisher by the drawing together of increasing numbers of indestrial prowluers in elependence mpon a minerity of

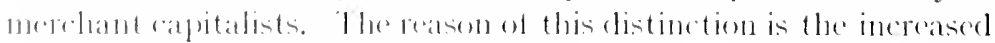
tarility for intertocal and international trate. The roastio of the comntry matrery likely have been worse in the reign of Henry VII 
than in the thirteenth century. They were, however, safer. Town monopolies had been largely broken down. The English trader went everywhere on the broad hasis of his English citizenship. He no longer crept into one town as the alien intruder from another. The effects of this change are summed 11p by a character in an imaginary dialogue, which was written about the micklle of the sixteenth century. "I knew the time when men weare contented with cappes, hattes, girdeles and poyntes, and all manes of garmentes made in the townes next adjoininge: whereby the townes then weare well occupied and set aworke; and yet the money paide for the same stuffe remayned in the countrie. Nowe the poorest yonge man in a countrey can not be contented either with a lether girdle or lether pointes, gloves, knives or daggers made nigh home. And specially no gentleman can be content to have eyther cappe, coat, doublet, hose or shirt made in his countrey, but they must have their geare from L.ondon; and yet many things thereof are not theare made, but beyond the sea, whereby the artificers of our townes are Idle." 1

This change in the structure of industry inevitably modified directly the organisation of the crafts and indirectly shifted the balance of town govermment. The elevelopment of burgess aristocracies in the fifteenth century is the political manifestation of an economic tendency. At the same time the majority of producers had slowly become wage-earners, dependent for their employment upon mercantile capital. In some of the London crafts a change analogous to the political evolution is perceptible: power becomes lodged in the hands of an aristocracy and lost to the mass of the masters. In others a mass of unorganised labour was taken on by the masters whose numbers ceased to expand. And there were intermediate cases between the two. In many towns similar causes produced a dependence of the craftsmen upon a general trating association. The interest of the commercial employer in selecting and combining freely different classes of labour led in the sixteenth century to the coalescence of kindred crafts beneath a single administration. Our knowledge of the detail of these processes is still scanty, though their general course can be indicated with confidence. We depend partly on the tenor of legislation, restrictive or regulative, partly on the documents of craft organisations. The latter,

\footnotetext{
1 Quoted Unwin, "Industrial Organization," p. 71.
} 
however, up to the present time have been only partially analysed. In the following pages we shall examine shortly a number of converging lines of evidence, in amplification of the description given above.

The growing importance of subordinate wage-labour is shown in some cases by records of conflict between employers and employed, by the regulation of the fees which might be exacted for admission to mastership, and by regulation of the number of apprentices which one master might employ. In all these cases the labour was so specialised that $(a)$ some training at least was required, $(b)$ the possibility of organisation existed. Where, as in the case of purely trading concerns, these conditions did not exist, we find no trace of conflict. The course of events is, however, substantially the same, though doubtless the amount of casual warehouse labour required by a wealthy london mercer was much less than the amount of skilled craftsmanship employed by an enterprising clothier. Evidence of the rise of a distinctive class of joumeymen, who have so little chance of becoming masters that they begin to organise themselves separately, goes back to 1303 when the jommeymen of the london cordwainers were forbidden to make ordinances for themselves. The sympathy with the Peasants' Revolt in many of the larger towns, especially London, seems to be comnected with the existence of a wage-earning proletariat, though doubtless the great majority were casual unskilled labourers such as never gained actmission to the craft organisations. Professor Ashley collects a long list of journeymen's associations in the fourteenth, fifteenth, and sixteenth centuries in various English towns. " "They are in London, the sadlers (1383-1396), the cordwainers (1387), the tailors (1413-1696), the blacksmiths (1435), the carpenters (1468), the drapers (1493-1522), the irommongers (1497-1590), the founders (1508 1579 ), the fishmongers (1512), the cloth-workers, and the armourers (1589); in Coventry, the weavers (before 1450), in Exeter the tailors (before 1512), in Oxford the shoe-makers (1512), and in Bristol the tailors (1570)." In most cases only an isolated reference or two remain. Where, as in the case of the London tailors, it is possible to trace the history of such an association over a consideralule period, it is fomme to pass gradually muler the control of the masters' association. Associations of jommeymen were never, it

1. Ashley, "Lconomic History." Vol. I, I’t. 11, 1) I23. 
would appear, so important in England as on the continent; we do not for instance find them regulated by statute. It is, however, plain that they were by no means uncommon. In the fifteenth and sixteenth centuries the growth of classes within the rank of masters, and the tendency for one craft to sink into dependence upon another, produced a class of small masters working for merchant employers by the piece, to which the journeyman could usually obtain admission if he desired to do so. This development was helped, no doubt, by the statutory regulation which aimed (1536) at the attempt of " divers masters, wardens. and fellowships of crafts" to prevent journeymen from setting up as masters. The existence of active national regulation might compel the English crafts to confer the title " master" on qualified workmen, it could not permanently check the economic forces which were dividing the conduct of industry between a minority of capitalists and a majority of wage-earners.

More effective in all probability, were the attempts to prevent the growth of unorganised labour outside the crafts, by insisting upon moderate apprenticeship fees. In the first instance this movement was caused, it appears, by a tendency of the master craftsmen to raise the value of their work by liniting their numbers. Thus the London weavers, early in the fourteenth century, were accused of restricting output, limiting numbers, and conspiring to raise their piece rate. The Act of 1531, however, which fixed the maximum fee for apprenticeship at half-a-crown with three-and-fourpence at the end of the term, when connected with the Act of 1536, suggests that the crafts were becoming close corporations of employers and were extruding the elenent of labour. The ultimate tendency of sixteenth century legislation was to accept the fact of subordination of wage-earner to employer but to regulate its terms. The idea of the statute of artificers is plainly that each industry shall have a certain corporate structure, that its wage-earners shall be formally initiated and trained, whilst on the other hand the institution of apprenticeship is not to be misused as a method of obtaining cheap labour which may afterwards be cast off.

The problem of apprenticeship, as is plain from nodern experience, is to strike the mean between creating a monopoly of skilled labour on the one hand and promoting the use of low-grade labour 
on the other. A developing conscionsness of this difficulty can be traced in England letween 1300 and 1563. At the lecginning the problem hardly exists. The conditions under which the gild system arose did not give rise to it. It hardly develops until it is possible for the individual to get more business than he himself and one or two assistants can cope with. Until this occurs the craftsman's assistants. often of his own kin, will naturally receive a good training, for there will be little specialisation within the craft. Even so. if population increases, the interest of the consumer may suffer. It may pay the craftsman to exclude outsidersto seek to create a quasi-hereditary monopoly. Thus the London weavers were already limiting their numbers. When the market expands the more commercially minded of the craftsmen will find their interest in increasing the number of apprentices. This will probably be resisted by the less enterprising, who fear that their own trade will suffer. At this point the dilemma for socicty arises. If the restriction is really successful, it means limitation of output - craft monopoly. If, as more often happens, the more enterprising evade the restriction, by employing uncosenanted labour in suburban and rural districts, the evils of unregulated production and oppressive wage srstems emerge. The Statute of Artificers is an attempt to solve the problem. So far as training and entrance to a trade are concerned, it exercises considerable influence until the conditions of the problen are upset once more by the Industrial Revolution.

That ajprenticeship should be a necessary preliminary to mastership had evidently become the general rule in towns by the end of the fourtcenth century: in the reign of Edward I it was probably not so. The Act of 1406 , which was framed to prevent the influx of agricultural babonr into the towns simply forbade men with less than fl per annum to apprentice their children. It would have had no sting if the practice of apprenticeship had not been firmly established. The interest of the landowners was here identical with that of the majority of the craftsmen. A sonse of this identity of interest is seen perhaps in the London ordinanee of 1387 that no villain should be apprenticed. That the restriction of apprenticeship had become a serions matter by the and of the fiftecuth century in very many towns seens ckear from the Act of 1531 noticed above. 
We find also in York an abortive attempt in 1519 to get rid of all restrictions on enployment. It has been urged by several writers that these restrictions were one of the chief causes of the growth of industry in suburbs and rural districts. The advantage of proximity to raw materials, and in some cases to water power. together with overcrowding within the towns, had probably more to do with this development.

Mr. Unwin's analysis of the changes in craft organisation, which resulted from widening of the market, reveals three typical processes by which control of an industry might pass from the hands of a number of small independent producers into the hands of a commercial oligarchy. ${ }^{1}$

(1) One of a number of related crafts might rise superior to the rest, its members becoming the employers of theirs, and supplying the trade link between them and the producers of raw materials or the consumer. Thus in London, in 1327, the sadlers were becoming superior employers of joiners, painters, and lorimers. They were also developing, it will be remembered, in 1383 a dependent journeyman class. In the cloth industry again about 1300 , burellers were giving out work to weavers, and even sometimes employed them on their own premises. It seems probable that the burellers' organisation developed into the drapers' company which was chartered in 1364, and became one of the great cloth trading companies.

(2) The trading function came very frequently to be exercised by a select body within the craft, the remaining masters falling into dependence upon this minority. The oligarchical constitution developed by many London crafts in the fifteenth century may have originated thus. The goldsmiths, the merchant tailors, the skinners, were probably all in the first instance associations of independent master craftsmen, but in these and other cases the real control of the organisation passed gradually into the hands of a minority of wealthy traders, little power remaining to the majority of craftsmen who continued to work with their hands. The development of a professional journeyman class which has been discussed earlier is another form of class subdivision within the craft.

(3) Organisations which had arisen to represent a purely trading

1 Unwin, "Industrial Organizetion," p. 19. 
interest might absorb crafts whose members had become dependent upon them for employment.

The process by which the majority of craftsmen sank into this subordination was of course gradual. Often one and the same man would work partly on his own account, partly on orders obtained by a more enterprising master. In London a number of wealthy merchant companies dereloped, many of which contained subordinate degrees of wage-earners. In the provincial towns a different grouping was reached-a consequence probably of the fact that in London only was there such a concentration of trade as to make it easy to form a number of specialised trade oligarchies. Usually a single merchant company was evolved which drew up out of the ranks of the craftsmen men whose ability made them formidable. monopolised municipal privileges. and became distinct socially; politically; and economically, from the mass of master craftsmen. It early became clear that the members of such corporations would not restrict themselves to managing any single trade if they conld see a profit in speculating outside it. Hence a coalescence of crafts. which brought the merchant employer into corporate touch with various kinds of labour. In many cases. as would be expected, such amalgamations were made within crafts whose economic relations were close-between several branches of the textile or metal industries for example. Such amalgamation would make possible a more efficient organisation of industry and possibly a further specialisation of process. In other cases the influence at work seems to have been merely commercial - the trader accepting existing methods of production without question. and seeking only to deal more conveniently with each class of labour.

In the Tudor period these oligarchic organisations were frequently incorporated as companies, a name which steadily displaced the older titles-mistery, craft, and gild. Is compared with the craft or even the gild merchant their functions were intlefinite and unimportant. They were, it is true, empowered to carry on the old craft programme, maintenance of cuality by search; to carry ont the regulations of the central government as the craft of the municipality. But the changed character of inclustry in some cases did not require, in others made impossible, the old methods. Is regards quality the merehant employers were individually well 
able to secure what they wanted, and if they were willing to sell shoddy, this was an evil which could not be cured by making them their own inspectors. No more could a thorough enforcenent of the act of artificers be expected from such bodies in the event of its being counter to their interests. It did, indeed, partly by endorsing, partly by adding to a developing body of trade custom, affect the terms of employment until the industrial revolution. But ten years after its enactment it was admittedly infringed on all sides. The perception by the government of the fact that the gild-form no longer provided adequate machinery for regulating trade, was a contributory cause of the granting of patents at the close of Elizabeth's reign and in the early years of the seventeenth century to indiridual capitalists or quasiprivate companies. Here as elsewhere the Tuclors fell back upon personal government where democratic institutions had evidently sunk into decay.

The craft organisation is important as containing the germs of modern trade-union action in some at least of its forms. The early crafts were not trade-unions, for $(a)$ their members were in most cases independent producers, and (b) regulation was largely imposed upon them to prevent them from exploiting society ; there was relatively. little attempt to prevent society from exploiting them; their position was naturally strong and not weak. In their later development again the trade-union element which occasionally appears, never permanently obtained the upper hand; they were instruments of the policy of the government, and the government aimed then at certain things which some trade-unions aim at now and at others (e.g. the prevention of truck) which both modern government and modern trade-unionism aim at. But the craft organisation had embodied the medieval ideals of stability, of restraint of detrimental competition, and of a standard wage; and the class of skilled wage-earners which arose upon its ruins preserverl the traditions of these ideals, and the tradition of corporate action. Further, the episode of urban craftsmanship weightily influenced the form which developing capitalism assumed. It gave to the nation a higher conception of the possible social importance of manual labour than could be derived from the manorial serf. In the two centuries which separate the Black Death from the statute of artificers, the urban craftsman had declined upon the 
whole in social estimation, but the agricultural labourer had risen more to meet him. The craftsman hat lost some of his freedom and most of his independence, hut the agricultural labourer, though he had not gained inclependence, had risen above the stigma of hereditary servitude.

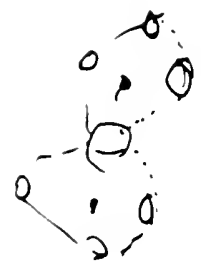




\section{CH.MPTER V}

THE GENESIS OF C.APITALISI

THE tendency towards a reorganisation of industry on a basis of wage labour, or in other worch the transition from the "craft " to the "domestic" system which has been examined in the last chapter, is the first indication of the approach of the capitalist era. Tle find men making profits by "turning over" stocks of commodities which they obtain from producers who depend upon them for employment. Such a system develops imperceptibly ut of mere commerce, as the trader exerts more and more influence upon the direction which production shall take: in other words, as his power of beating up a market becomes more and more indispensable to the craftsman. 1t deserves the epithet "capitalistic" as soon as this dependent relationship is dereloped, whether the craftsman becomes technically a wage labourer or continues to dispose of his wares in a market which is technically open.

Medieval town regulations were evidently hased on the assmption that each craftsman and trader would own the appliances and stock which were required for his business. His " business" was limited in thought, as also for the most purt in practice, to a continuous personal exertion, fundamentally laborious but involving also a modicum of special dexterity and special knowlerlge. The economies of trade or production on a large scale were not foreseen clearly. They have been forced upon the attention of society by the enterprise of individuals. Failing in foresight. society made no attempt to reach this more efficient organisation by co-operative effort, which might secure an orderly progress and a collective distribution of gains collectively produced. The change was brought about by the accumulated weight of successful inclividual experiments, and the chief profit of the change fell in to the individuals who experimented successfully. It is clear that throughout the Middle Iges the more vigorous tornsmen were constantly attempting to pass beyond the limited earning-porrer of the labouring craftsman and the operative trader. In order to do this it was necessary for them, in the absence of credit facilities, to accumulate a larger supply of capital than that with which the 
normal craftsman or trader works. They must be able to speculate in the product of other men's labour to a considerable extent, and in order to do this they must control sufficient funds to buy up with a view to resale the product of the labour of many men. Even this statement does not fully explain the difficulty of rapid accumulation, for it does not draw attention to the slow rate of turnover. If a trader in the Middle Ages turned over his stock twice in one year he probahly felt that he was doing exceedingly well. The more usual rate was once-as will be evident if one considers the enormous proportion of trade which was concerned with agricultural products. Where distant royages hall to be undertaken the rate was still slower. Nor does it appear that the normal profits were particularly high. The view that they were so is a mistaken deduction from the (often) enormous margins which separated the purchase and sale prices of commercial conmodities. This margin can be proved in particular instances to have been due to high costs of transport and onerous tolls, and to have left no more than a moderate insurance for risk in addition to the trader's class standard of income. On the gromnd of these considerations Dr. Sombart ${ }^{1}$ maintains that the capitalistic enterprise of the fifteenth and sixteenth centuries in England and Cormany, and of earlier centuries in Italy and the Netherlands, cannot possibly have grown out of the slow accumulation of trade and landicraft profits, and though, as will appear later, it is difficult to accept the whole of his solution of the problem. all subsequent historians must start from his theses.

Ifter exhiliting the difficulty of accumulation by the normal tracler or craftsman sombart propounds the question-what (op) portunities of making a fortune dicl exist? and answers with a reference to the financial administration of the Crown, of great landowners, and of ecclesiastical bodies. In collecting the incomes of great landowners or landowning corporations, whether those inrones resulted from money, rents or taxes, or from the sale of agricultural surplus products, in managing the (Englisli) national finances, in collecting the papal taxes, individuals passed throngh their hamels the procluet of the labour of great numbers of men, and aprart contirely from perulation and extortion (both of which were common), the realisation of large profits was possible. Still more improtant were the gains derivable from the combintion of

1 "De. moderne Kippitalismus." 
such work with credit or usurious transactions--.the atrance of momey the security of income or taxes, the purchase at enomous discount of the right to collect dues, and the farming of taxes. The quantitative importance of finance, adninistration, and banking, as compared with trate and handicraft in the Midelle. Ages, has certainly been muderated by most economic historians. Ve must remenher that the system indicated was not eonfined to the royal finances. It stretehed lownwards through the princely households of the higher mobility, both lay and ecclesiastic, to quite small landlords. $\quad 1 \mathrm{t}$ is true that in England at least the bailitfs or reeves who managed individual manors cannot be suppresed to have made large profits. Apart from the care with which accomnts were kept-at least in the thirteenth century--it is clear that the offue was onerous, and that often the ford more or less compelled a villim to undertake it. But the constant result of incalculable exienditure on war and luxury was that the finances of the Crown and of landlords generally were in chronic disorter, and this circmmstance admitted of large profits being realised, both honest and dishonest. Just as these large incomes which rested on socio-political, or theorcratic, and not on economic gradations, were for centuries the chief cause of specialised trade and handicraft in the tom - just as they necessitated a comage at a time when the masses were organised in self-sufficing communiti's almost indepenclent eron of barterso they called into existence large scale tmanciers and bankers, at a time when traders and craftsmen owned the whole of the capital which they operated, and were only driven to usury by exceptional disaster. Thus it is clear that the Jewish community in Englanel in the twelfth century had accumulated, by financing the upper classes, wealth compared with which the earnings of the average burgess were inconsiderable. The Jews were expelled tarly in the reign of Edward 1 , but the neressities of the upper classes continued throughout the next two centuries. By whom were those necessities supplied? For a time the Crown had recourse to Itatian houses - a practice initiated as early as the reign of Johu. and increasing throughout the thirteenth century. From 1276 to 1292 the men of Lucca advanced money to the Crown against tiits right to collect certain of the customs; in 1294 the Crown enploys ten firms of Lucca and Florence; a little later it is the Frescobaldi, and then the Bardi. Edward III repudiated his debts and causcd 
thereby the collapse of the principal Florentine hanks in 1345. For a time Netherland financiers hold the field, and at last in the fifteenth century the main business passes finally into English hands. But this transition hat been long preparing. The great English merchants of the fourteenth and fifteenth century--so far as their history can be investigated--are almost withont exception money-lenders to the Crown and trusted financial agents of the Crown. The De la Poles of Hull and the famous Richard Whittington may serve as examples. They are the founders of English "high finance." If we remember the ramifications of Jew finance in the thirteenth century through all ranks of the landlordly aristocracy we shall be compelled to regard the De la Poles and Whittingtons as the heads of a great profession. We find in Hull, and London, and Bristol large scate money-lending going hand in hand with the beximnings of large scale commerce; and we shall assume that hurgesses generally throughout the country began to compete with the Jew money-lenter in the thirteenth century and replaced him in the fourteenth, and that much of the capital which we can watch flowing into trade between 1300 and 1500 was acemmulated originally and continued in the intervals of trade speculation to be angmented in this way. In ficturing the conditions we shall take account of the demand for more or less considerable commissariat organisation and for financial operations of all kinds in connection first with the crusades and subsequently witl the French War and the Wars of the Roses. As regards the Hundred Years' War, in particular, we shall decluee in addition to commissariat proper the more or less speculative fitting out of knights and companies, to be repaid later out of loot and ransoms. We shall, further, connect with the dependence of large commerce and finance on aristocratic and govermmental expendiwne the influx into the burgess ranks of the carlets of good families. They are attracted not merely beatuse trade is beginning to be a career which yiclds a gentlemanly -in some cases a princely-income, but becanse gentle birth is beginning to yade a competitive arlvantage in trade. For, other things being eprat, the be la Poles, who trace deseent from a Norman Complerer, the younger son of Sir William de Whityngton, High sheriff of Cilourester, will have opportmities which meaner men will lack. Their aristocratic connections will give them first choice 
of aristocratic business, and will commend them to the wealthiest heiresses in the burgess community. It may be added that their birthright of command, self-confidence, initiative, and freedom from convention, will fit them for the leadership of the mercantile community.

Sombart carries still further his analysis of the origin of capitalism. Having established the fallacy of the idea that normal profits were exceptionally high in the Middle Ages, he proceeds to seek the origins of the small accumulation which is required as a preliminary to money-lending even at 40 per cent., and finds them in ground-rents. Attention is drawn to the fact that the trading oligarchies which arose in England in the fifteenth century and are found earlier on the Continent, usually consisted of families which owned the land on which the towns stood, and were recruited from the landowning families in the neighbourhood. And since it has been shown that traders and craftsmen can hardly ever have accumulated any considerable sum by their own exertions, we reach by elimination the conclusion that the root of all capitalism is to be found in " unearned increments." If its root is "unearned" so also are its first shoots-at least mearned in any ethical sense. From the exploitation of landowners, themselves the exploiters of the masses, capitalists passed on to colonial exploitation, which begins with Italian enterprise in the Levant, and lies behind the international politics of Western Europe in the sixteenth, seventeenth, and eighteenth centuries.

This conclusion jumps so suspiciously with one of the main tendencies of modern economic thought that there is a real danger of its being accepted by some, rejected by others, and not considered at all. To the present writer it appears that Sombart is misled by the fact that normal profits were not extravagant into undue depreciation of the accumulative power of the more successful traders and craftsmen. It is difficult to dismiss as mere misapprehension the contemporary belief in this power, however much we allow for the tendency of "politicians" to exaggerate the importance of trade, especially foreign trade, at this epoch. The whole tenor of medieval town regulation seems unintelligible except on the assumption that then as now some men earned more than others and used this surplus as a groundwork for rising, either by superior bargaining power, or by superior organising power, or merely by better fortune, 
above the general level of traders and craftsmen. We may agree that the man who owned some ground rents or who could bring to bear aristucratic connections in the country was more likely, other things being equal, to rise than those who were not so provided. But the fact of general coincidence between ownership of real property and membership of a town oligarchy is at least as likely to be due to the investment of the rising man's sarings in house property as to the rise of those who already owned it. I cannot see reason for breaking entirely with the traditional view that generations of moderate prosperity would gradually raise this or that burgess family above the general level and put it in a position to take advantage of openings for money-lending and large scale commerce. I cannot believe that we should find London handicraft gilds gradually rising into the ranks of the great trading companies unless by a process of this nature. The evidence seems to point clearly to the conclusion that the trading oligarchies which arose within these cratts were the result of accumulation of cupital in the hands of individual craftsmen who gradually, as they rose, ahandoned the labouring function. Again the trading oligarchies of provincial towns in the sixteenth century consisted of men of very various degrees of wealth, from small shopkeepers to considerable merchants. It is reasonable to suppose that the sons of the former might displace the latter, or vice versa, and it alpurars also that rising craftsmen were taken up into these oligarchies.

It may rerliups be concluded that but for the existence of large inomes of a political and tasational character the growth of capitalist control over industry woukd have been less rapid, whilst the social gulf between employer and wage-eanner might never have been cleft. Is things were, the minority of successful speculators worked their way rapidly to a standarel of life epual or superior to that of the aristocrary, whibt between them and the labourer several degrees of serried smolubishness were planted inexpugnably. The new employers thus either entered the governing class or felt connerted with it by throe who hat chene so. In the fifteenth century fwe find them formding schosh where their chideren may leam to be gentemen, and reading mannats of gentlemanly behaviour. The

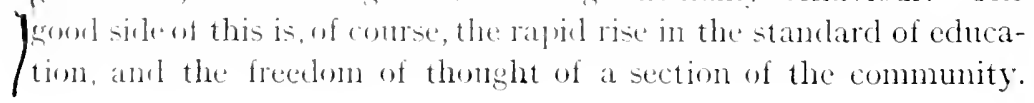


The bad is the indefinite prolongation of social distinctions which had originated in force and cunning. We shall weigh against one another in judging the faets. on the one hand the manifold evils of hereditary class-inequality. on the other the stimulus to experiment and initiative which individual wealth made possible. Existing culture is largely the product of class distinctions, but it has yet to be shown that no better culture was conceivable without them.

Since the accumulation of capital was left by society to individuals, the tone of capitalist industry was largely set by the character of those individuals who possessed special aptitudes for accumulation. And here a distinction must be drawn between several distinct classes. Among the merchant princes we find men like Whittington, who have imbibed the patriarchal attitude which was the best tradition of the society in which they moved. They are capable of princely generosity-and not merely in their wills. They found schools and hospitals. They humanise the poor law. In larger social imagination they are, it is true, somewhat lacking. They can manipulate admirably the finances of the country, but they cannot or will not reorganise them. Amongst the lesser merchant adventurers who push foreign trade we find an heroic blackguardism of initiative combined with thirst for monopoly and a naïve conviction that their interests are ahwars identical with those of the King and the nation. Their physical courage is discountenanced in modern communities, though the type crops up constantly in romances of distant islands. The small eapitalist organisers of inland industry, the clothiers especially, are gradually losing the generous impulses of town civilisation. Between their desire to sweat and cheat their employees and the desire of the goremment to prevent social disintegration, the war goes on for centuries. "In the occupations of cloth-making." says the statute of 1465 , " the Labourers thereof have been driven to take a great part of their wages in Pins, Girdles, and other unprofitable wares . . . and also have delivered to them wools to be wrought by excessive weight," and again, "Item that every Man and Woman being cloth makers ... shall pay to the Carders, Spinsters, and all Labourers in any part of the said Trade lawful money for all their lawful wages and payment of the same, and also shall deliver wools to be wrought according to the due weight thereof." And below these are numbers of small middlemen masters, working themselves side 
by side with their few emplorees-driving them by tongue and example to their own adrantage. The other side of the picture must not he neglected. Apart from legislative protection of the minimum standard there were forces which kept capital kindly both in country and in town. As was seen in an earlier section the number of rural labourers who were entirely landless was very small at the end of the sixteenth century-if aniy at all there were. The Elizabethan statute. forbidding the erection of cottages with less thon four acres of land, points with other evidence to this conchusion. Hence the workers in the mual domestic industrics, both then and later. either regarded their industrial earnings as a hre-product of the time not required for cultivation or raised at least a certain proportion of their liring from garden patch or paddock in the intervals of their industrial work. In either event their dependence upon the trathing employer was incomplete. In the towns the situation was less satisfactory, but even here in some cases the surviral of the gild spirit, combined with the general tenor of national regulation, protected certain sections of the small masters and reomen. The reader may be referrecl to Mr. Lnwin's interesting account of the London Clothworkers' Company in the sisteenth century, which is summarised as follows:--" The Cloth-workers' Company is a typical example of the new species of organisation which replaced the Craft Gild, in the sense that it embraced the two distinct classes of traders and of craftsmen. But the special interest of the cloth-workers' organisation lies in the unusual degree of equilibrim in which the interest of these two classes were maintained for a consiclerable perienl." 1 such equilibria were, of course. more likely to introfuce a comservative epoch in the history of the local inclustry than to provide for a measured development in which the interests of all parties womk be respected. Thus we tinct the Cloth-workers" come of dusistants refusing to adopt labour-sirving machinery offered to them hy a lenetian inventor, and restraining their members from organising the manufaturing process on a larger scale. It is probalde that we have here one of the reasons. though doubthes at suberfinate one, for the fact that the future of the inderte lay in the rumal clistriets and not in the old town rentres-sulurelinate, locause if the anditions of the town

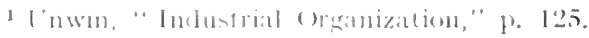


production had otherwise been farourable one must suppose that the capitalists would have found a way round or over the obstacles of tradition.

No detailed history of the rise of capitalist industry in England has yet been attempted, though valuable contributions towards one already exist. A general outline of what is known can be presented most easily under the following heads: I. The woollen inclustry: II. Foreign trade; III. Finance; IV. Large scale production. These divisions are not, of course, absolutely distinct. Thus large scale production is found occasionally in the woollen industry, and there is a persistent comnection between Forcign Trade and Finance.

I. The development of the woollen industry.

It has been seen in an earlier chapter that the cloth industry from the first inclined $(a)$ to produce a class of specialised traders, and $(b)$ to localise itself in particular towns and districts. The rough fabrics woven on the rural manors could only be collected and distributed by speculative traders who visited for one or other purpose the fairs and markets, or even sought ont the producer in his own home. The finer products of the town crafts were distributed from each urban centre over wide districts. One place became famous for " scarlet," another for " blanket," a third for " russet," insteacl of each centre supplying all the chief varieties to its immediate neighbours. It is doubtful, however, whether in this preliminary stage of the industry any large proportion of the makers were so dependent upon the dealers as to be classed properly as wage-earners. In the rural districts it was for the time being only a small surplus of the product that was sold to traders for export beyond the neighbourhood. Iost of the product was either consumed in the family or disposed of to other members of the village community of which the producing family formed part, or of neighbouring villages. In the towns the producing craftsmen were still on a tolerably equal footing with the ristributing traders, and met them in the regulated contracts of the municipal market, just as in the great textile industries of the modern workd the manufacturer sells his wares to dealers who are customers for his products rather than employers of his labour.

This was the condition of the industry at the end of the thirteanth century. In the next hundred years its reorganisation commences, 
the most significant events being $(a)$ the immigration of foreign artisans, promoted by the govermment of Edwart III, and (b) the growth of the worsted industry in the Easten comnties. The importation of skilled labour from Flanders was demanded by the relatively hackward condition of the English craftsmen. It was assisted by the oppression of the Flemish artisans whose democratic ambitions were crushed at Cassel in 1328. There are extant, from the years immediately following, letters of protection from Edward III to individual Flemings, and in 1337 a statute was passed promising "franchises as many and such as may suffice them" to all foreign cloth-makers who shall come into the comitry. The results of this invitation soon became apparent. In I,ondon from 1344 onwards there are occasional traces of the collision of interests between the old-established weavers' gild and the immigrants, and though evilence from other parts of the country is less plentiful there are traces both at Bristol and at Norwich which seem to show that the cloth industries of East Anglia and of the West comtry were equally indebted to this influx of foreign skill. The Norfolkshire worsted industry had indeed reached considerable dimensions before the immigration. Is early as 1315 it was becoming evident that it had ontgrown the possibility of adequate local control. Its market was so far extra local that the interests of the consumers were imperfectly represented. Is a result, inspection was carried out imperfectly, ancl there was much complaint of fraud in the "lengths" solk. In 1329 there is evidence that the craftsmen were scattered over a consilerable area. Serenteen centres are mentiones of which seven were iclentified with the production of worsteds. Serenty vears later $(1410)$ a petition shows that the worsted industry was the "staple tratle of Norwich, the second rity of the Kinglom," and "enumerates as many as twentyone different sorts and sizes of worsted cloth as requiring sujervision." 1

The expansion of the inchesty in the fourteenth and fifteenth centuries was no doubt the reason of the freepuent changes made by the gerermment in the machinery for securing satisfactory length and guality of the enthe exposed for sale. The old rule which geos back to the assize of measures muler Richarl $I$, and was repeated in the cireat chater, was that " woollen cloths, wherever

1 . Slleky, "Economic Ilistory," Vol. I, I’t. II, p. 209. 
they are made, shall be made of the sane width, to wit, of two ells within the lists, and of the same goodness in the middle and sides." Under Fdward I an aulnager was appointed to execute the assize and his duties were defined and re-defined in a succession of statutes during the next two centuries. The influx of Flemish weavers under Edward III, who brought with them the skill of new varieties of cloth, made it necessary to depart from the simple terms of the original assize. In 1353 it was ordered that " the King's aulnager shall measure the cloth and mark the same, by which mark a man may know how much the cloth containeth, and by as much as the cloth shall be found less than the assize, allowance or abatement shall be made to the buyer." This measure was not a final settlement of the question, probably in consequence of the practical difficulties of marking numerous varieties. During the next two centuries experiments were marle in the direction of grading cloth in a linited number of classes, and a final settlement was attained by this method in the reign of Edward VI.

Of the statistical history of the exports of cloth we know little until the reign of Henry VIII. If we may rely on an account printed by Misselden in 1623, the exports of cloth amounted in 1354 to less than 5,000 pieces, and those of worsted to just over 8,000. These data agree pretty well with the fact that the Hanse Merchants, who paid toll in 1307 on six cloths only, were paying in 1422 on 4,464 , and forty years later on 6,159. On the accession of Henry VIII the national exports had risen from the 5,000 pieces of 1354 to 80,000 . At the end of his reign the total stood at 120,000 . The decline in the exports of wool became important from the very beginning of the fifteenth century. It is thus evident that a very rapid expansion of the manufactures took place from this time onwards-sufficient to absorb not only the whole of the increased sirply of wool provided by the enclosure movement, but also an increasing proportion of what had previously been exported. With this view hamonises the fact that protection against foreign competition became more and more systematic from the reign of Edward IV onwards. This expansion grew out of the movement in the fourteenth century considered above; before the end of the fifteenth century we find traces, in addition to the East Anglian industry, of localised cloth industries in "Bristol and in the counties thereabouts," at Kendal, 
at Coventry, and in Surrey, Sussex, and Southampton. With all this progress, in the reign of Elizabeth the English still lacked the skill to finish the finer kinds of cloth. These were almost exclusively imported from the Continent, our own exports consisting of "whites," i.e. unfinished cloth. and it was necessary once more to resort to immigration, which was faroured by religious persecution in France and the Netherlands. The migration began as early as 1544. and though temporarily suspended under Mary. who even expelled some of those who had already come. was resumed under Elizabeth. After 1567 Alra's persecution fed the stream. The new comers settled for the most part in London and in the South and Eastem Counties: the new arts were only gradually absorbed by the English inclustry. The attempt of James I to dispense with imports of cloth broke down in utter failure.

The transition to capitalistic organisation must have been nearly completed at least as early as 1400 , though for some time longer in the towns the proportion of master workers of a fairly solid position was probably high. In the sixteenth century the government was able in some measure on sereral occasions t., throw part of the burden of crises in the industry upon the capitalists by compelling them to continue to employ the workers when demand slackened.

The cloth industry remained beyond comparison the most important manufacture in England until the Industrial Rerolution. But cluring the fifteenth and sixteenth centuries a similar change of organisation can be seen both in minor branches of the cloth industry. $e^{\prime}$.. cap-making, and in other industries whose products couid be transported so cheaply that they commanded a market throughout England or abroad. These conditions were fulfilled in many branches of the leather industry-espocially glove-naking, and of the metal industries-e.s. pin-making and cuthery. We may notice as indications of the industrial transition the rise to inportance during the sixteenth century of three new commercial and manufacturing centres-viz. Birmingham. Sheffield, and Manchester.

11. The development of foreign trate.

It the end of the thirteenth century the export trade of England consisted almost entirely of rav materials, the trade in unfinished coth was only begmning. Furthermore. the carriage, both of 
exports and imports, was almost entirely in foreign hands. By the end of the sixteenth century the exports of raw materials had almost entirely ceased. Manufactured products, prineipally unfinished cloth, had taken their place. Almost all the export trade and a large proportion of the imports was now carried in English ships. We have then to take account of two distinct though connected movements, (1) The substitution of manufactured exports for raw materials, (2) The rise of native enterprise in sea carriage and foreign markets.

The importance to the Crown of the customs duties charged on exported raw materials led in the thirteenth century to the establishment of the Staple. To this institution there were two sides. First, it denoted an organisation of the English merchants throngh whose hands these exports passed out of the country ; second, it defined either the ports from which they might be sent, or the foreign port to which they might be sent, or both. It will be seen that, whilst definition of the ports of departure facilitated the collection of customs duties, definition of the port of arrival gave the Crown a valuable lever in its diplomatic relations with foreign comtries. It was in fact employed to this end by Edward I, who occasionally diverted the flow of English commodities from Brüges to Dordrecht or Antwerp. Finally the two considerations, financial and diplomatic, were united in the choice of Calais, which became the final seat of the Staple about 1390. This choice at once made the collection of customs easy, and provided a natural basis for the growth of an English interest in Calais. It should be added that the cost of garrisoning Calais consumed a large proportion of the tolls obtained. During the first half of the fifteentl century the Merchant Staplers were a powerful company, whose members lived either in English ports or in Calais, who directed the export trade of the country, and chartered if they did not provide the necessary ships. The institution was not, however, likely to promote the general export and import trade of the country, since although foreign merchants could be compelled to fetcli from Calais the English monopoly wool, they could not be compelled to fetch English commodities which were not monopolies-e.g. manufactured cloth, nor could they bring commodities to any great extent to exchange for the wool, since the extra charge of carriage was prohibitive. We shall see later that the staple commodities 
exported via Calais were paid for either by bullion or by bills drawn on the financial centres of the Netherlands, which were used in turn by English import houses to pay for commodities procured from the Netherlands.

The Staple could thus only play an important part in the foreign trade of the country so long as the monopoly commodity of wool continuer to be an important export. And several distinct causes combined to displace it. On the one hand the English cloth industry had an inherent capacity for expansion as skill was gradually acquired. On the other hand this natural process must have been enormonsly favoured by the artificial adrantages of the English as compared with foreign cloth-makers. The extra cost of carrying the raw material as compared with the finished article must alone have been considerable. It was, however, increased by the obligation of foreign manufacturers to get their wool from Calais instead of direct from England. There was no douht much smuggling, but illicit trade even then was probably more risky than legal trade. and therefore more expensive. It was also possible to secure licences from the crown for direct export, but such licences had to be paid for and were in any case a precarious basis for enterprise. Finally. the arrangenent of export duties favoured enormously exporters of cloth as compared with exporters of the raw material. It is easy to understand why although the staple dragged out its existence until the loss of Calais, its importance had long since been superseded by other developments.

The attempt to turn into an impracticable channel the main body of English trade placed the fate of English enterprise in the hands of inclividuals who were, at first at least, in a small way of business. The staple tended to include the large export houses, and to exclude the small men, with the result that the large houses followed routine whilst the small men shifted for themselves. They harl to compete with foreign buyers already established in England, and to fore their way into forergn markets which were more or less forcilly held against them by the powerful mercantile associations of the continent. On the other hand there were increasing opportunities for crasting trate abont the Inited linglom whirh were furthered greatly by the hreakdown of municipal monopolies in the fourternth and fifteenth centuries. The great trade in coal from Vewastle to london, which berame subsequently one of the 
chief nurseries of English seamanship, can be traced back to the reign of Edward I. And the Hundred Years' War necessitated a constant transference of supplies and men across the Channel and to the Garonne. Thus we find in the fourteenth century traces of the growth of town fleets at many of the English ports. This form of enterprise gradually gave place to the joint adventures of combined bodies of small merchants, and finally, as wealth increased, to individual enterprise. These early shippers were known as merchant adventurers: they were par excellence the "tramps" of the period as opposed to the "regular lines" and "rings" of older and more established enterprises. Where they went they fought, attacking the weaker, defending themselves against equals and superiors. By the middle of the fifteenth century we encounter individual merchants who already control a considerable tonnage. Thus William Canynges, of Bristol, in 1461, had ten ships. whilst "John Taverner, of Hull, in 1449, built a great 'carrack' on the scale of the mighty ships of Genoa and Venice." 1 At the close of the fifteenth century "English vessels carried more than a half of all the cloths exported from the country, and about three-quarters of all other goods." 2

A tendency towards monopoly and organisation had become evident at the very beginning of the fifteenth century. In 1406 the company of Merchant Adventurers was incorporated by Henry $I V$. and after the final removal of the Staplers to Calais the control of English trade to the Netherlands passed to them. In 1407 they were granted a perpetual Hanse in Antwerp, and their importance grew steadily as exports of raw materials to Calais were displaced by exports of cloth to the Low Countries. They were strong enough to prevent Staplers from sharing in the new trade unless they joinod their company and paid extra fees. They survived the opposition of the Netherland weavers, whose prosperity disappeared before the influx of English cloth. They kept up a constant warfare on the preserves of the German Hanse in the Baltic and in Scandinavia. They carried the English flag to Italy and the Levant. The fifteenth century was a tuming point in the commercial history of Europe. The advance of the Turks in the Eastern Mediterranean cut the communications with

1 Green, A, "Town Life in the 15 th Century," I, 89.

2 Green, A, ibid., I, 94. 
the East, which had been one of the main roots of Italian city prosperity. The discovery of America and the Cape route to India prepared the supremacy of oceanic nations. In the North the capture of No,gorod by the Muscovites, the growing hostility of the Scandinarian kingdoms, and of Prussian and Livonian cities, ate into the power of the German Hanse. Their Steelyard at London was continued until 1597, but for a century before this date it had existed on sufferance.

In considering these changes it is well to estimate justly the part played by political influences. The Navigation Acts of the Tudor periof are a symptom rather than a cause of the growth of the English mercantile marine, a fact which was fully appreciated by Elizabethan statesmen. But the decline of the great cities both in Italy and in Northern Europe cannot be ascribed simply to economic causes. It is evident that the possibility of national soliclification is giving certain new countries an advantage in the competitive struggle. These nations can distribute the cost of defensive and offensive war over large populations. They can feed at small expense the necessary armies. The Hundred Years' IVar is a disaster for England and France alike, but it will not rum either: whilst the Italian cities, exhansted by the struggle with the Turk, will be an easy prey for French and German and Spanish armies in the sixteenth century. The towns in the German Hanse cannot form a consolidated polity capable of prolonged effort. They sink one by one into decadence and are absorbed finallysometimes late in the nineteenth century-by the gathering power of nationalism.

Neantime the merchant adventurers of England, whilst tending steadily to organise each ascertained market on a monopolistic basis, throw off again and again their sepuadrons of pirate tramps to break new ground. In the Tuklor period they cannot make solid progress in transoceanic conquest against the national force of Spain and l'ortugal. They sting and loot and incidentally do their fair share of adventurous exploration. But with the incorporation of the Mnscory Company in 1555, the levant Company in 1581, the last India Company in 1600 , we see the close of this first stage of commercial expansion. In the serenternth rentury we shall find the markets of the workl parcelled out to chartered companies, and individual 
initiative compelled in its search for openings to attack monopoly directly.

\section{Finance.}

The early history of English finance has been little investigated. and it is possible that no material for a consecutive account exists. Many financial operations were discountenanced for centuries by opinion and legislation, and althongh we find frequent condemnation of prevalent usury, those who knew most about it probably said least. We have seen earlier in this chxpter that the English Crown from the fourteenth century onwards, became increasingly dependent on native banking houses. It was, however, long before they altogether abandoned resort to the foreigner. Edward IV, and later Mary, were under considerable obligations

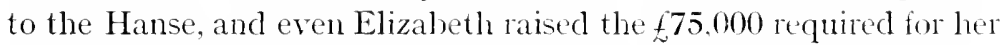
scheme of re-coinage in Antwerp, though from the importance of the merchant adventurers in that town, and the immediate transference of financial business to London after its capture by Alva, we may conclude that much of the capital employed there was already English. It seems clear that Antwer 1 , in the middle of the sixteenth century was a chief centre of international arbitrage and dealings in trade bills, and it is certain that the leading merchant adventurers took their part in these operations. The legalisation of interest in 1545 shows that trading on borrowed funds was becoming more common. Dr. Cumningham has collected a number of isolated expressions from the Elizabethan period which show the prevalence of the practice. ${ }^{1}$ It is even probable that certain branches of finance were already specialised, for instance sea insurance. The earliest form in which this was effected was by the investor loaning to the merchant a sum sufficient to fit out the vessel on condition of receiving back his capital plus a premium if the ship voyaged safely. In the sixteenth century this system began to be displaced by the modern plan-the merchant paying a premium before the voyage and receiving an indemnity in case of loss. Borrowing with a view to lending-i.e. deposit banking-was probably not practised in England though it was most certainly on the Continent. There seems no good reason to doubt the tradition that before 1640 merchants habitually deposited uninvested surpluses in the Tower, and that only when Charles converted these deposits into a forced

" Growth of English Industry and Commerce," ** pp. 1+2-161. 
loan did the practice arise of depositing money with the goldsmiths, who subsequently lent it out. The origin of the goldsmiths' connection with finance is certainly money-changing. The abantonment by the Crown of its attempt to monopolise this business (also in the sixteentle century) is another indication of the rise of financial interests. Speaking generally, there is no sign that finance hat entirely separated itself from the conduct of trade-in other words of the rise of a special profession of banking.-but we may, perhaps, detect. in the increasing importance of the goldsmiths under Elizabeth, coupled with the energence of banking from that profession a hundred years later, signs of the withdrawal of the ordinary trader from money-lending. In this connection it is worth noting that almost alone of the trades which demanded large capital the goldsmith's gave little opportunity for investment of accumulating resources. The more the merchant adventurer earned, the more trade ventures he could undertake. The demand for plate was comparatively inelastic, and the goldsmith therefore was constrained, if he were successful, to push the financial branch of his business more than the trading and mamufacturing.

IV. large scale production.

The capitalist movement, in its first stages, was primarily financial and commercial. It is comparatively rare to find production organised on a large scale on premises, or with machinery or appliances, owned by the employer. Nevertheless, there are sufficient traces of beginnings in this direction a!so to make the matter of some improtance-especially when accomt is taken of the development of this form of capitalistic enterprise since the Industrial Revolution. Alostractly considered, we should start here from the great sheep-runs of the Midlle Ages, and their extension thring the enclosure movenent. We have indicaterl earlier the growth of capitalistic speculation in agriculture, and chawn out the characteristic traits which mited the sheep farmer and the Merchant driventures. Concretely it is seldom consenient to do more than draw analogies between capitalism in agriculture anel capitalism elsewhere. The importance in the former of systems of land tenure, the inexoralbe differences between raising products by growth and manipulating them by hand or machinery, mark off agriculture for separate consideration. Apart from agrienlture, three points call for separate discussion: the occasional aplearance of the 
larger unit of production in industries which, however, retain the domestic as their predominant type; the increasing use of capital in mining and metallurgy and in branches of other industries which require expensive plant; an l the investment of considerable sums under patent rights in the introduction of new or foreign processes or in the re-organisation of existing industries by control of the supply of the raw material.

(1) Evidence of a tendency on the part of individuals to increase the scale of production in the cloth industry goes back to 1339 , when Thomas Blanket and other citizens of Bristol were fined by the civic authorities for setting up looms and employing labour on them in their own houses. Incidental references to the practice are found occasionally in the fifteenth and sixteenth centuries. More commonly individual capitalists speculated in the tools or machinery of an industry, renting them out to the wage-earners. This was the usual course of development where, as, e.g., in the stocking industry, somewhat complicated machines were introduced. The practice existed, however, in older trades and the "Weavers' Act " of 1555 enumerates it among the methods by which wealthy clothiers were oppressing the weavers-." some by ingrossing of Looms into their hands and possession, and letting them out at such unreasonable rents as the poore Artificers are not able to maintain themselves." Preventive legislation, as has been pointed out by Mr. Unwin, was linited to clothiers dwelling " outside a city corporate or market-town." The same writer draws the deduction that the Act was the fruit less of syinpathy with the oppressed weavers than of jealousy of town versus country clothiers. On the other hand, the stronger tradition of the gild system would be likely perhaps to limit the growth of the systen in the towns. It is possible that the town clothiers, holding themselves bound by these traditions, regarded the competition of large scale businesses in the country as unfair.

It is clear that a tendency towards an embryo factory system was visible in the rural districts at this time, and there is traditional evidence of the existence of productive units which would be classed as factories to-day. A versified history of John Winchcombe of Newbury, of which the first edition was possibly printed as early as 1597 , tells us that :

"Within one roome being large and long

There stood two hundred Loomes full strong." 
Each weaver (achult males were employed) was attended by a "pretty boy." A hundred women were carding. Two hundred girls were spinning. A hundred and fifty children were picking wool- " the children of poore silly men." There were fifty shearers. eighty rowers. forty dyers and twenty hands in the fulling mill. ${ }^{1}$ There is possibly exaggeration here. Winchcombe died some time after 1519. hut his son continued the business and Wincheombe's "kersies" enjoyed a European fame in the middle of the sixteenth century, and the importance of the name does suggest some detailed organisation of production. Moreover, though factories which integrate a large number of processes are familiar to us moderns, it may be doubted whether tradition could create the conception if none such existed. In any case. large scale organisation did not become characteristic of the cloth industry until considerably later. Professor Ashley has worked out the advantages which it conld offer even apart from the use of machinery, and inclines to think that the establishment of the system was actually prevented by legisla.tion, and this is not impossible. The "movement re-appeared again at the end of the seventeenth and during the eighteenth century, when a certain number of manufactories were established,--even before the introduction of machinery gave the final impulse towards the aggregation of work people." 2

(2) In some branches of industry, however. plant was already recpuired which could not be provided for each worker by himself. and here, in the absence of capacity for co-operation the capitalist was a necessity. The localisation of the finishing processes in the cloth industry was largely determined by the search for waterpower to drive the machinery of the fulling mills. Thus, whilst yarn continnes to be spun throughout the country, we shall find weaving gravitate more and more to the South West and North West. We know little of the history of the fulling mill, but we find in the Weavers' Act of $\mathbf{1 5 5 5}$ the provisions that "No weaver shall have a tucking-(i.e. fulling-) mill, and that no tucker shall have a loom in his honse or possession." This seems to show a tendency towards integration of other processes with the one mocess requiring capital which was resisterl in the West Riding (though not in other districts) until the ludustrial Revolution. Water-power was also

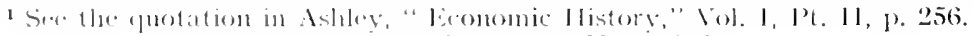

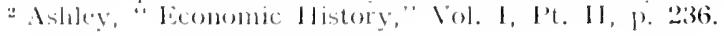


becoming important in the iron industry. where it was mployed as early as the sixteenth century. to drive mechanical bellows and tilt-hammers. The industry was to some extent controlled by the aristocratic owners of the land where ore and fuel were obtainable in proximity. Both in mining and in metallurgy improved processes were being introduced from the Continent-especially Germany-by adventurers who could get together the necessary funds.

(3) As noted earlier, the Elizabethan patents were granted on several different grounds. Leaving aside those in which the principal object was to farm ont an excise knty on the industry in question, or provide a salary or peusion for an official or farourite, we may distinguish two principles: (a) Reward of invention, (b) Reward of importation of a new process. "The study of these patents has brought into prominence the very interesting facts that the planting of new industries was a capitalist undertaking, organised by moneyed men, who were prepared to wait some years for the full return on their outlay." 1

${ }^{1}$ Cunningham, "Growth of English Industry and Commerce," ** p. 7S. 


\section{CHAP'TER VI}

MONEY AND TAXATION

WE have seen that for two centuries after the Norman Conquest the standard coin of England was almost unaltered in weight and fineness. In the next three centuries the weight was enormously reluced, atthough the standard was maintained except for a few years in the midule of the sixteenth century. The weight of the silver penny was 22 grains troy in 1300: 18 in 1351: 15 in 1412: 12 in 1464; 12 in 1504; 8 in $1552 ; 7_{4}^{3}$ in 1601. So striking and persistent a contrast evidently implies some permanent and considerable alteration, either in the attitude of mincl with which the English sovereign regarded the problem of money or in the nature of that problem itself.

It can hardly be doubted that the latter is the true explanation. It is impossible to believe that English sovereigns, up to 1300 , were honest, and for two hundred and fifty years after that date dishonest, without exception. Moreover, it may be remarked that the case of English money is not isolated. Similarly distinctive periods are seen in the currency history of other Emopean nations, ${ }^{1}$ though the dividing line fell earlier on the Continent than in England. In regard to the depreciation in the reign of Edward III, the following argument may be quoted. "A govermment decply in delet can effect a diminution in the capital amount by a debasement or depreciation, and profit to that extent; and no doubt if the serret can be kept, a government can profit by a secret alteration of the standard. In France serret dehasments, debasements to pay debts, and debasements followed by restoration to the original stanclard dirl occur in the thirteenth and fourteenth centuries; and probably the theory under consideration has arisen chicfly from stmely of french eviclence. But the application of it to the English debasements of bewarel $1 \mathrm{ll}$ is unfortunate; for they are marked by no secreer, there are not followed by any attempte at the restroration of the standarel, while for the payment of his telots belward II I

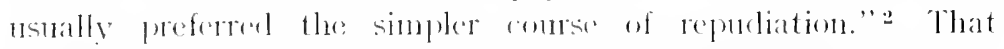

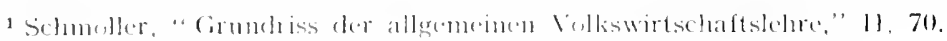

a Hughes, Crumb, and Johnson, "Ecomomic Journal," \'1, 189. 
opinion in England distinguished between justifiable and illicit alterations came out very clearly in the reign of Henry VIlI. The reduction of the weight of the penny from 12 to $10 \frac{1}{2}$ grains in 1527 and again to 10 grains in 1542 was not resented. But everyone felt that the Crown was swindling the nation when in 1545-6 the amount of fine silver in the testoon was reduced from five-sixths to one-third.

If we abandon the idea that the Crown, after 1300 , took a less serious view of the problem than before and turn to consider the problem itself it becomes evident that a variety of causes conspired to make the maintenance of the weight of the coin more difficult and burdensome. In the first place it is eviclent that the expansion of trade, both domestic and foreign, must have increased the number of coins used in the country considerably, and still more the anount of wear to which each coin was subjected. The payment of troops during the French war and the Wars of the Roses must have entailed a comparatively rapid circulation of comparatively large sums, and the increased use of money in commerce was an even more important factor. More rapid abrasion would make reminting at the old weight more difficult whether the loss involved were assumed by the Crown or thrown by it on the holders of the worn coins. Fraudulent reduction of the weight of coins by clipping and sweating had always been, as seen above, a serions difficulty. So far as the evidence goes there is no reason to suppose that it diminished during these centuries, whilst the increase in foreign trade rather favoured the introduction of inferior or spurious foreign coins. A further result of the closer connection with foreign commtries was the growth of international arbitiage. The heaviest coins were naturally selected for export, and those which escaped the sweater disappeared in this way. The profession of arbitrage was promoted by the attempt to make gold circulate side by side with silver at ratios fixed by law. The ratios fixed usually differed in different countries, and constant changes were made sometimes with the view, apparently, of attracting part of the currency of another nation, more generally to resist export of bullion from the country where the change was made. As relations between the chief European money markets became closer, it was increasingly impossible to keep any full weight coin in circulation by the side of light weight. Whenever export of coin was necessary the heavier 
coins were selected. It will appear later that during the greater part of the period the general bullion policy of the government compelled a transference of bullion into (and therefore out of) England much greater than would have been necessitated by the ordinary course of trade. The occasion for bullion export was therefore chronically present instead of only occasionally as the balance of trade inclined this way or that.

The fact that the best coins were regularly picked ont and exported is the hey to the progressive depreciation of the currency. It seemed clear to the ordinary man that the circulation of worn and perfect coins side by side enabled arbitragists to make a profit at the expense of the State. If the average weight of the English penny had been reduced by wear or frand from 20 to 18 grains troy, foreign countries in tariffing their own against English currency would, of course, make a corresponding reduction. At the same time if an arbitragist picked ont the new full weight pennies and treated them as bullion, he could secure from the foreigner a higher price. Such middleman's profit might have been prevented either by calling in light-weight and substituting fullweight coin, or by reducing the silver content of new coins to the arerage silver content of those actually in circulation. Several intelligible reasons would determine public opinion in favour of the latter course. In the first place, it was immediately easier as involving no direct expense either to the holder of light-weight coins or to the state, and further as avoiding the inconvenience of a general re-coinage. ${ }^{1}$ Secondly, in the general confusion of thought on the subject it is probable that if the expedient of re-coinage harl been seriously considered, it wonkl have been rejected on the following gromuds. It must be remembered that the evolution of coinage was still almost entirely empirical: men were feeling their way by tonch from one point to another with a minimum of theoretical insight. Now the starting point of contemporary interest in currency reform was the fact that individuals harl a sinister interest in picking ont and melting down full-weight coins. The obrions ways of preventing this evil were (1) to punish wh individuals whererer posible. (2) to remove temptation l, no honger isming the class of coin which had been

1 In inconveniene which lecame, of contse, more and mure serious as the commercial use of money expinded. 
melted down and exported. The expedient of raising the existing currency by a re-coinage to the traditional weight might well seem hazardous. Experience showed that coins issued at that weight were rapidly melted down and exported. Would not the re-issue of the whole currency at that weight result in the whole currency being melted down and exported? Experience showed on the other hand that light weight coins were not melted down. There was thus a prima faci: case for supposing that if all coins were light weight none of them would be melted down. When we add the general impression throughout the mercantile community that the supply of currency in the country was inadequate, we can understand the acquiescence of Parliament in the policy which was maintained. ${ }^{1}$ If it is difficult to see what other course was really feasible at the time it is still more difficult to quarrel with its actual (though doubtless largely accidental) effects until the close of the fifteenth century. So far from debasement between 1300 and 1500 having unsteadied prices, it provided a safety valve against the tendency of prices to fall in consequence of the steady appreciation of silver as compared with other commodities. In the first half of the sixteenth century, on the other hand, when the tide was already beginning to turn against silver, the debasement coincided with a rise in prices.

The technique of coinage was really very little altered during the centuries, though a fairly steady improvement in workmanship was maintained, and in the sixteenth century men came to know more about refining. The old method of striking the coins by hand, hammer, and die was maintained well into the seventeenth century. Certainly any improvement in technique that dicl take place was inconsiderable as compared with the more general importance of coin in the economy of the country and the increased complexity of the currency itself. We have noted already the introduction of gold coins in the fourteenth century. The difficulty of maintaining gold and silver issues in circulation at a fixed ratio was continuous both in England and abroad. Although, of course, a survey of the Mint ratios between the metals in the various European

1 On the other hand a single step bevond what was necessary. or mere coincidence between alteration of the coins and some other cause disturbing prices, called forth protests. Thus, in 1353, when the content of both gold and silver coins was lowered, and the ratio altered, a rise in prices was attributed $t o$ the change, and the country murmured. 
countries from the fourteenth century onwards shows a general similarity of movement, ${ }^{1}$ they were seldom absolutely identical in two countries at the same time, and yet more seldom altered simultaneously. The use of gold currency was a product of trade expansion. The inconvenience of silver for large transactions was more and more felt. Thus it spread to England from the Netherlands. Flemish florins lad circulated here before 1344 , and the English issue of that rear aimed at the establishment of a common commercial currency for England and Flanders. In addition to the adoption of gold, the requirements of trade called in the sixteenth centmy for increase in the variety of denominations at which silser coins were struck.

Throughout these centuries legislation was from time to time demanded and passed with the object of remedying a felt dearth of money for the purposes of trate. It is impossible to fix a date at which the demand for measures which should maintain the national supply of money generated the mercantilist principle of regulating foreign trate primarily with the object of increasing the national supply: but the years from 1500 to 1550 are generally accepted as marking the definite transition from the one view to the other. It has often been asserted that one chief cause, if not the only cause, of the international struggle for bullion which began to influence Englanu at least as early as 1300-1350, was an actual cleficiency in the supply of bullion throughont Europe. It is impossible to reconcile this assertion with the facts. In the first place, so far from the struggle being ented by the increase in supplies during the sixteenth century, it was, as seen above, only in that century that England at least developed the mercantile theory in its complete form. Sceondly, whilst it is true that the purchasing power of silver in limope rose considerably between 1300 and 1500 , the debasement of the currency even in England, where it was slight as compared with what occurred in some other conntries, prevented this appreciation of silver from lowering currency prices. Thirdly, in the case of England there is evidence of sery great accumulations of plate and jewellery in spite of chronic complaints of inadequate currency. An Italian observer tells us that in 1500 the fifty-two goldsmiths' shops in the strand contained more silver than the goldsmith' shops of Rome. Milan. Venice. and Florence together. and

'see tables in Shaw, "The Ilstory of Currency," ple, 40, 69, 70. 
that even small householders had their silver table service and plate to the value of 100 . Even if we allow (as we probably ought to) some ninety per cent. for exaggeration it is difficult to square this account with the view that the country could not get sufficient bullion for currency purposes. Still more interesting, as throwing light on the real origin of the difficulty, is certain evidence in connection with Wolsey's attempt to collect a "tenth" in 1523. The Norwich clothiers explained that if the town were drained of coin they would be unable to pay their workpeople week by week, and offered instead their silver plate. We may conclude that the root of the evil was not inadequacy in the supply of bullion, but the attempt to base speculative commerce and a monetary revenue system upon an inelastic currency. Here again, as was observed of minting technique, improvement by no means kept pace with the increased complexity of business.

The measures which were taken to guard against monetary stringency may be divided into three classes (1) those which aimed at preventing melting down and export of bullion, (2) those which aimed at securing a regular influx of bullion to the Wint, (3) the gradually developing mercantilist policy of restricting imports and encouraging exports which aimed in its earlier stages at preventing bullion exports, in its later at encouraging bullion imports. As regards the first two classes of measures the evil struck at was only in a secondary degree monetary stringency. Their primary object was prevention or remedy of those frauds on the currency which were rendered possible by the imperfect technique of coinage. It can, however, hardly be doubted that these frauds were viewed with the more severity on account of recurrent stringencies. It would be natural when the market was tight to believe that but for the culling and exportation of heavy pieces a larger supply of coins would have been available. Of course no regular addition to the supply of coins in a country whether produced by prevention of export and melting of coins, compulsion of minting, or favourable balance of trade, can cure the difficulties which arise from fluctuation in the requirements of trade. Such attempts are precisely analogous to attempts to cure fluctuation in the labour market by decimating the population, or doubling the regular army. On this ground some writers have concluded that all these regulations, even assuming that they were not evaded, can only have accentuated the evil by 
increasing friction and deferring the evolution of a true remedy. On the other side it may be urged that the eril produced by preventing any' fluctuation in the quantity of currency would have been less than the evil produced by permitting such enormons fluctuations in its amount as woukl otherwise have taken place, that the restrictions on export and melting and the encouragement of minting, whilst they could not of course prevent fluctuation altogether, minimised it, and that they were therefore on the whole advantageous to the country. To put the argument in concrete form, granting that the finally desirable solution, was an elastic currency varying by 10 per cent. plus or minus, regulations which kept the variations down to 2 per cent. ma y have been preferable to a freedom which would have led to variations of 50 per cent.

We must add that there are no sufficient data for determining either what degree of elasticity was required, or what degree of variation actually took place, or what degree of variation would have taken place but for the restrictions. It does, however, seem probable that since the import regulations at certain times demonstrably brought bulfion into the country, whilst the export restrictions were notoriously unable to prevent its export, a great deal of bullion must have travelled backward; and forwards between England and the Continent by sheer compulsion of the law. The new money thus arbitrarily issued from the lint camnot have been ahways required at the moment of its issue. As often as it was thrown upon an easy market it or its equivalent would be melted chown and exported. In considering the matter it should be remembered that although the State was not in a position to supply a satisfactory currency, the rising financial profession hat alrearly developed in Europe considerable power of dispensing with bullion remittances and distributing funds between the chief commercial centres. The idea that but for the intervention of the State bullion would have been shifted indiscriminately from one country to another as the trate balances inclined this way or that is fuite mutenable. Then as now international trade would have been setted chiefly hy credit, and the flow of bullion deternined by changes in the interest rate. ${ }^{1}$ bealers in exchange were, howerer, obmoxions on sereral grounds.

I For a description of elaborate trade sethement loy lills in the reign of

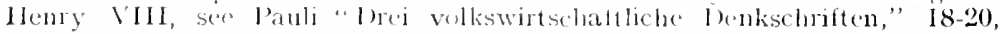
quoted Schanz, "Englische Handelspolitik," I, 500, note. 
They were suspected of usury and fraud on the coinage; they seemed to have mysterious powers of fixing rates in accordance with their own interests; it was difficult to show that their work was of service to England or of disservice to England's rivals. ${ }^{1}$ It is generally easy to show that some immediate injury has resulted from obstruction of economic processes whose nature has not been grasped; but in this as in other cases some countervailing advantage is discoverable. The principle of requiring everyone who makes money to satisfy society that he gives value for it has far-reaching effects, first in clearing up questions which in turn illuminate related problems, second in weeding the movement which is thus thrown on the defensive of its more objectionable traits. ${ }^{2}$

Legislation aiming at the prevention of export of coin goes back to the thirteenth ${ }^{3}$ century and becomes detailed and complicated in the first half of the fourteenth. There is little doubt that it was actuated in the first instance solely by the desire to prevent loss of coins which the Crown or individuals had been at the cost of minting. At all times licences to export for certain purposes were granted with more or less freedom. The statute of 1299 and subsequent enactments forbad the export of bullion and plate as well as of coin. This addition cioes not imply mercantilist riews, since it would have been idle to restrict export of coins if export of bullion were permitted. In 1339 the policy of compelling importation of bullion was commenced by the order that " plate of silver" to the value of two marks should be brought to the royal exchange table for every sack of wool exported. The immediate object was to supply the coin required for the French war. Analogous measures of great complexity were continued for two centuries with more or less success. The idea that the supply of bullion could be regulated by manipulating foreign trade so as to produce a favourable balance was clearly expressed, as noted earlier, in 1381. It does not seem, however, to have secured much attention until

\footnotetext{
${ }^{1}$ It was, of course, cosmopolitan.

${ }^{2}$ Finance and trade-unionism have each, at different times, been compelled to make out a case against intensely hostile criticism. Each has gained enormously from this compulsion, and the controversies of which they have been respectively the centres, are the two tap-roots of economic study.
}

${ }^{3}$ Restrictions had been imposed uccasionally from a very much earlier date. 
after the strong movement for the protection of native industries had commenced in the second half of the fifteenth century. In the fourteenth century and even as late as the reign of Henry VIII it required some imagination to conceive of the export and import trate of the country as an organic whole. It was not until a much later late that public opinion generally rid itself of the habit of regarding the trade balance between England and individual countries as of primary importance. Is early as 1528 we find Sir Thomas More contending that all fear in regard to sufficiency of bullion supplies is irle., "for the intercourse being so established throughout the worlel, there always will be a perpetual circulation of all, that is necessary." But this view found little support until the eighteenth century.

It was noter above that the debasement of the standard in the last years of Henry VII was regarded by contemporaries as on a different footing from previous rectuctions in the weight of coins. In the policy of Elizabeth is discoverable a conservative reaction to the traditional methods of the fourteenth and fifteenth centuries. The stanchard was restored by her re-coinage, but no attempt was made to return to Henry VIII's reductions of the weiglit of the pemy. ${ }^{1}$ And further the cost even of restoring the standard was thrown upon the holders of the debased coins. The nominal value of the rebased testoons was rried down, and they were taken by the Nint at the value of the silver contained in them. ${ }^{2}$ At the end of the seventeenth century we shall find a surken revolution of practice in both respects-worn coins being re-coined without resluction of weight and the cost borne by the nation. not by the holder. In currency as in other matters the reign of Elizabeth brought not an innovation but more efficient and conserntive practice of ideats, whose roots racher back for centuries.

It will be convenient in our examination of the national finances to consiefer in turn four groups of contributions. First, property, income and poll taxes: second, customs duties: third, quasi-private receipts; fourth, axeptional exattions.

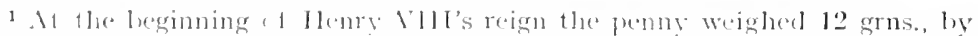

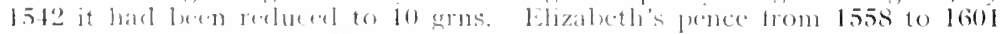

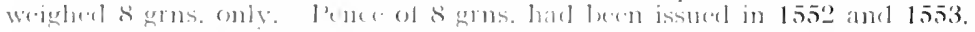

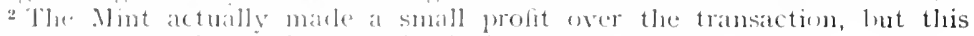
apporently was the risult of a miscalculation. 
I. Property, Income, and Poll Taxes.

\section{The Fifte'ntl and Tinth}

It was seen that in the thirteentl century the system inaugurated by the Saladin tithe of demanding certain proportions of all men's movables had become the principal form of direct taxation. Its collection, however, offered considerable difficulties, the chicf being that of securing equitable assessment of the property which it was proposed to tax. A somewhat similar difficulty had already led to the adoption of commutation in the case of the "ferms" of Boroughs. An analogous development in 1334 was destined to alter materially the nature of the fifteenth and tenth. The tax commissioners in that year were ordered to treat with local authorities throughout the country and settle with them compositions for the tax. The change was no doubt at the moment a great boon, preventing both evasion by individuals and peculation by the collectors. But the very ease (comparatively) with which the system worked tended to stereotype it. The "fifteenth and tenth" from that time forward meant a definite sum of money, $c a$. $£ 39,000$, distributed in a known way between different towns and districts. If more or less than $\_39,000$ was required a grant of so many fifteenths and tenths, or such a proportion of a fifteenth and tenth was made, much as the income tax to-day is moved up and down by so many pence. The "certainty" thus given to the tax was a great advantage, but as the relation between the wealth of different towns and districts varied, the burlen of the tax was more and more unfairly distributed. From time to time a reassess ment was proposed, but this was always resisted successfully by Parliament.

\section{Poll Taxes.}

In 1377 a new expedient was tried. A poll tax of 4d. was taken from every man and woman above the age of fourteen except beggars. In 1379 the experiment was repeated in a different form. The tax of $4 \mathrm{~d}$. a head was evidently inequitable; it had also brought in only some $£ 22,000$; an attempt was now made to range men in classes, and assess a suitable rate for the individuals in each class. The charges varied from $£_{6}$ 13s. $4 \mathrm{~d}$. for the Dukes of Lancaster and Bretagne down to $4 \mathrm{~d}$. from every married man who was not a beggar, for himself and his wife. This tax was in intention a very 
fair attempt at proportional taxation. It was, however, too complicated to succeed. The actual incomes within each social class were so different that it was necessary to qualify assessment by class with assessment by income. Thus, e.g. the mayors of the smaller towns were charged $f 1,10$ s., or $6 \mathrm{~s}$. Sd. according as their wealth was more or less, and so in other cases. This inevitable qualification robbed the tax of its apparent simplicity, and opened the door to evasion on the one hand and oppression on the other. Evasion apparently had the better, for less than half of the sum anticipated was actually collected. A compromise between the simple poll tax of 1377 and the elaborate income tax of 1379 was attempted in 1380, the object being no doubt to secure some of the simplicity of the former without its intolerable inequity. From the fifteenth and tenth the principle of apportionment was borrowed. Each parish was required to collect a certain sum equivalent to 1s. a head from every lay person, male and female, above the age of 15 . This total, it was intended, should be shared out by the parish amongst its inhabitants in proportion to their wealth. It was provided, however, that no individual should pay more than $f 1$ or less than $t d$. for himself and his wife. The results of this tax were even more unsatisfactory than those of its predecessors. Its collection was the proximate cause of the Peasants' Revolt in 1381. No further general poll tax was attempted until 1513, though poll taxes on aliens were conmon in the fifteenth century. The tax of 1513 cansed little ill-feeling. It closely resembled the income tax of 1379 , and suffered from the same defect, viz., it brought in less than one-third of the total estimated.

\section{Subsidies}

From the Peasants' Revolt until the enrl of the Hundred Years' War in 1453 , a series of experiments were tried generally with the view of adding to the yield of the fifteenth and tenth. The most interesting were the land taxes of 1404 and 1411 , and the income taxes of 1435 and 1450 . These income taxes, like that of the present day were confmed to incomes above a certain limit. In 1463 and 1472 fruitless attempts were nade to levy the fifteenth and tenth on a new assessment. Ifter the failne of the poll tax in 1513, a fresh attempt at a general property tax was made, a general subsidy being granted of $6 \mathrm{l}$. in the pound on all goods. $A$ survey of the Kingdom was made in 1522, and in the next 
year Wolsey demanded a fifth of the value of goods and land as determined by this survey to be paid by the laity in five years. Throughout the remainder of the period the vote of fifteenths and tenths combined with subsidies continued, but the tendency towards fixedness which had overtaken the former in 1334 quickly spread to the latter. As a fifteenth and tenth had come to mean a sum of about $£ 39,000$ levied in ascertained fashion, so the subsidy came to mean a sum of about $£ 80,000$. Throughout the Tudor period the Subsidy Acts contained, it is true, directions for accurate assessment to the subsidy; there was, however, practically no reassessment. "The various counties and towns, and within them the various divisions and hundreds and wards, paid as near as might be the amount previously paid for a subsidy, and any readjustment . . . that took place was limited to a rectification of the rolls of the subsidy men in the particular districts." 1 In fact the yield of the tax rather declined than advanced in the later years of the reign of Elizabeth.

II. Customs Duties.

Customs on wool, woolfells, and leather were granted to Edward I by Parliament in 1275 and were known as "ancient " or "great" customs after 1297. The expense of the French war led him to attempt to increase the revenue levied at the ports. These attempts issued in 1302 in an agreement between the Crown and the foreign merchants by which fixed charges on the goods imported and exported by them were substituted for the traditional prisage of wine. These new charges were partly specific, partly ad valorem. They comprised (1) the "butlerage" or "tumnage" on wine of 2 s. a tun imported; (2) the "new" or "small" customs-i.e. specific duties on wool, woolfells, hides, cloth, and wax: (3) the ad valorem duty of $3 \mathrm{~d}$. in the pound on all other exports and imports-" poundage." In 1303 the King attempted to conclude a similar arrangement with native merchants. The attempt failed at the time, and it was not until 1376 that an agreement was reached. During the fourteenth century export duties on wool formed one of the chief resources of English finance. In addition to the regular charges of the "old" and "new' customs, special charges were imposed from time to time analogous to the irregular levy of property and income taxes. The practical monopoly of England in the supply

1 Dowell, "History of Taxation," I, 197. 
of wool placed her in a strong position in this respect. and it seems exceedingly probable that a large proportion of the regular charges at least were borne by foreign countries. In respect to the occasional charges there is more doubt. The landowners. of course, alleged that the merchants paid them less for their wool by the amount of the tax.

From Edward IV onwards every sovereign at the beginning of his reign received a grant of "customs" together with " tunnage" and "poundage" for the term of his life. The decline in the exports of wool had by the end of the fifteenth century reduced considerably the rield of this side of the revenue. The rise in prices in the sixteenth century combined with the fact that the principal duties were "specific" led to a further decline in its real value. Moreover the system of collection adopted left room for enormous frauds. It is probable that the loss on the commodities which were charged at percentages of their declared value. was greater than the loss orer the specific duties. The values of imported articles subject to poundage were officially fixed by a book of rates in 1558. which was equivalent to converting ad ralorem into specific duties. The Venetian Ambassador calculated in the reign of Mary that of the $f 200,000$ or thereabouts actually extracted from the merchants, scarce one quarter came into the Treasury. ${ }^{1}$ In addition to peculation by the customs officials there was much smuggling and evasion. After 1586, when a new book of rates was framed. a firmer arministration was set up. and the revenue increased rapidly in the next twenty years.

III. The Royal Demesne and Feudal Dues.

Throughout these periols the theory continued that the permanent expenses of govermment ought to be defrayed chiefly from the private revenues of the Crown. It was only with great reluctance that the Commons accepted the necessity of a permanent increase in the customs whilst the direct taxes never lost their primarily orcasional character. There were, howerer, three reasons which marle the maintenance of this system more and more difficult. In the first place the charges of government tended to increase rather than diminish as time went on. The practice of requiring owners of property to perform public duties without payment was by

1 "The value of this estimate is fuestioned ly Cumningham, "Growtly of English Industry and Commerce," * 549 . 
no means abandoned, even when new departures were taken. Neither Nembers of Parliament nor Justices of the Peace were paid official salaries. ${ }^{1}$ The ships which fought the Armada were for the most part ordinary merchantmen fitted out for the occasion by volunteers or seaports. But from the French war onwards the forces employed in foreign expeditions were composed principally of paid professional soldiers, and in the sixteenth century the Royal Navy began to be of some importance. Secondly, alienation of the Crown lands made upon the whole more rapid progress than their increase by confiscation. Very large proportions of the land of the country were confiscated during the Wars of the Roses, and again by Henry VIII at the dissolution of the monasteries. In the former case all and more than what was gathered was dispersed again to buy support: in the latter the extravagance of Henry VIII and his courtiers ran rapidly throngh the produce of the confiscations. Thirdly, the great rise in prices during the sixteenth century greatly reduced the purchasing power of the royal income.

IV. Exceptional Exactions.

The expulsion of the Jews in the reign of Edward 1 threw the business of finance into the hands of Italians and Flemings, and eventually of Englishmen : in any case it deprived the Crown of one important source of occasional revenue. So far as occasion offered, however, English sovereigns continued to exact money from the financial profession; whether by borrowing and subsequent repudiation (Ed. III), by benevolences (Ed. IV Elizabeth), or by monopolies. The repudiation of Edward III was facilitated by the fact that the chief sufferers were Italian depositors with Florentine banking firms. In general this expedient was avoided. We find Elizabeth for instance methodically clearing off in the early years of her reign a considerable burden of debt inherited from her predecessors. In the case of benevolences it is of course very hard to draw the line between exactions proper and more or less voluntary " contributions" such as were made, e.g. to l'itt during the Napoleonic wars, and of which a last faint sluadow is discernible in the "national" war loan a century later. Again the benevolence might be gladly granted in return for more or

1 Members of Parliament were, indeed, permitted to charge their constituents with a certain sum for expenses-and, no (loubt it was sometimes difficult to distinguish between "expenses" and "salary." Anyhow, the matter did not concern the Crown. 
less definite "ralue received." 1 Edward IV's demands for benevolences did not outweigh in the opinion of the towns generally his services to trade. On the famous occasion when Morton's "fork" was employed "Henry. VII had the quasi-parliamentary anthority of a grant from a great council." 2 Monopolies were not used by Elizabeth to any important extent with the object of bringing in money to the exchequer; they provided, however, a convenient method of pensioning and finding salaries for servants and favourites of the Crown. The consumers had cause enough of complaint in the last decade of the sixteenth century as was shown abundantly both by the debates in the Commons in 1601 and the immediate retreat of the Crown from a position which had proved untenable. I list of monopolies of articles of common consumption was read aloud. " 'Is not bread there?' Mr. Hackwell stood up and asked; adding subsequently, 'If order be not taken for these, bread will be there before the next Parliament." "3 It was the first appearance of the "big loaf" in English political life. The Queen used strong language in regard to some disclosures that were made, speaking of "the harpies and horse-leeches then discovered to her." The removal of the most obnoxious monopolies actually followed, but the matter was treated as a question of grace, a waiving of the royal prerogative. The doctrine of parliamentary control was established "by blood and iron" in the next century.

The finance of the country during these three centuries was in a transitional state. The heary-handed efficiency of Norman and Angerin lings, working through fear and prestige, was gradually undermined ly parliamentary procedure, whilst yet l'arliament had too little share in the executive government of the country to set up an efficient system of its own. Such a division of power is inevitably detrimental to financial order. ${ }^{4}$ In the sixteenth century financial policy is either inefficient. as under Henry VIII. or penurions and timid as under his predecessor and Elizabetl. There was little room for free handling of the new problems which

\footnotetext{
1 Compare the financing of the Conservative and l,iberal parties in our own day by the distribution of t!tles to these who have " deserver well."

21)(swell, "History of Taxation," I, 201.

3 Quoted l owell, "History of Taxation," 1, 206.

"Its clisturbing intluence is markedly present in the finances of Germany and the Inited states to-dar.
} 
the development of national power was bringing to the front throughout Europe. But the urgeney of those problems conkl be delayed no longer. It was necessary to elecide whether the control and direction of the nation's expentiture should be rested in the hands of a "patriot king," or of men who had a stake in the comtry, and stood to lose or win by national failure or success. 



$$
\begin{gathered}
\text { BOOK IH } \\
\text { THE ANTECEDENTS OF } \\
\text { THE INDUSTRIAL REVOLTION }
\end{gathered}
$$





\section{CHAPTER I}

GENERAL SURVEY

THE century and a half which separated the death of Elizabeth from the accession of George III was a periou of preparation. Throughout it the forces which caused the Industrial Revohution were slowly gathering momentum. It is for this reason clusive of historical treatment, for these forces worked underground for the most part ; they are only occasionally visible. The surface of the national economy was strikingly little altered; new industries, indeed, arose, and new trades were opened up, but such progress was conducted for the most part on lines marked ont already in the sixteenth century. There are no structural changes of the larger kind. The relations, both social and economic, between employer and wage-earner, landlord, tenant, and labourer, were at the close of the period very much what they had been at its commencement. But although in the phenomena of industry there was little material change, the same is not true of men's attitude towards these phenomena. The society of educated men, the governing English class for which Adam Smith wrote, conld enter into, even if it did not already accept, views which were entirely alien from the lingland of Elizabeth. The conception of natural law and its power to produce a social equilibrium without the intervention of government had been developed in the meanwhile. This conception was one of the mainsprings of the impending economic revolution. It in part made that revolution possihle; in part directed its course along lines unnecessarily evil.

The administration of Burleigh constitutes, as noted earlier, the high-water mark in England of efficient direction by the central government of the economic growth of the nation. With the possible exceptions of Strafford and Walpole, no statesman of the seventeenth and early eighteentl centuries had the same combination of breadth and shrewdness: and political accident prevented both these men from developing their irleas with the freedom that was possible for Burleigh. Ender James I and Charles I the general agreement that economic matters onght to be regulated by the central government was more and more challenged by the 
growing desire to restrict the power of the Crown in non-economic matters. At the same time the lack of revenue led both these monarchs to abuse their economic authority, or rather to subordinate in some measure the real economic interests of the nation to financial exigencies. Had their general policy been agreeable to the mass of the nation it is possible that less would have been made of the injury inflicted on individuals by patents and monopolies, though it should be remembered that even under Elizabeth the grant of monopolies caused a conflict between the Crown and Parliament. In the early years of the serenteenth century the incipient hostility to arbitrary industrial regulation was strengthened by distrust of the general aims of the Crown, and the desire which resulted from that distrust to limit its financial power. Behind these considerations, though doubtless accentuated by them, hes a growing insistence upon certain " natural rights " of Englishmen -the economic application of ideas which were undermining at the same time loyalty to the Crown and to the national church. "At the root of the opposition to monopolies and trading companies there seems to have heen a strong feeling that every Englishman had a 'natural right' to trade as he liked, provided he did not interfere with the liberty of others. Cecil, while defending Elizabeth's grants in the Parliament of 1601 , condemned as 'misdoers and wilful and wicked offenders' those who would 'take from the subject his hirthright;' and the opponents of the trading companies in 1604 appealed to the "natural right and liberty of the subjects of England 'in support of two free trade bills." 1 it is well not to press overmuch such phrases, for with or without a systematic philosophy the man with a grievance against anthority feels always that his natmal riglyt is injured. They are important rather as showing that governmental regulations had become, for one reason or another, so unpopular that the doctrine of natural right was worth putting forward - in other words that numbers of people were reatly to receive any doctrine which offered a basis for conscientions resistance to anthority. In this connection some weight should be giren to the increase of confidence during Elizabeth's reign. The very excellenee of gorermment by promoting stability makes mon more critical. Upon the whole, however, there was more far ground for criticism in the economic regulations

"Howins, "Jinglish Trate and finance," p. xii. 
of the first two Stuarts than in those of Elizabethan statesmen: there was more incompetent conceit in high places, Janes I in particular being rendered by it an almost comic figure.

But the opposition to regulation in the early part of the serenteenth century was exceedingly limited in its ams. The traders who claimed their natural rights had no more wish to establish laisser faire than did Puritans lesire to prepare a place in the state for professed atheists. What was resisted both in foreign and in domestic trade was the restriction of existing traders in the interest of a privileged minority. A line which was clear enongh in practice was drawn between monopoly and regulation: the former seemed to enable one section of traders to exploit other sections and consumers, the latter aimed at conciliating all interests. The actual decay of governmental regulation of trade which preceded the industrial revolution was far more due to change in the structure of gorernment than to change in public opinion. It would seem that an almost accilental and certainly unpremeditated destruction of the machinery of government produced conditions of relatively free enterprise, and that experience of these conditions gradually weaned men's minds from desire of regulation. In France and other European countries. where political development was different, a far larger element of detailed control survived until the close of the eighteenth century.

If we sum up the results of the constitutional struggle in the statement that the control of Parliament over the executive was established, we have a clue which explains the chief changes in the method of economic regulation. In the first place the system of monopolies was no longer politically practicable. At its best this system had meant the selection by the government of the individuals who should organise and direct particular industries, at its worst it had permitted individuals to squeeze existing industries. A monopoly of the former kind, however ably and honestly the individuals were selected, would give dangerous opportunities to a parliamentary opposition. The latter kind would be certainly fatal to the government which granted them. It is to these reasons even more than to the statute of monopolies that we should look in seeking to explain the cessation of the systen in England. Representative government leaves ample room for the restriction of industry in the interest of classes, but is hardly compatible with 
such restriction in the interest of individuals. It has been urged very properly that the English Parliament has been responsible upon the whole for much more class legislation than the English Crown. It is at least arguable that Crown government, even under the Stuarts, gave a better guarantee against this particular abuse than any I'arliament of the seventeenth or eighteenth century could offer. It deserves to be remembered on the other hand that the Rebellion and the Revolution put an end to the arbitrary disturbance of industry in the interests of individuals. The courtier "placeman" was less dangerous to the economic welfare of the country than the courtier "patentee." In so far as the monopoly system harl been an ontcome of the financial needs of the Crown, the change in the political srstem made it no longer necessary. The Crown, in order to go behind Parliament, had been compelled to farm to individuals the right to tax producers. Parliament could adopt the simpler expedient of appointing excise men. The notorious jobbing and overparment of such posts in the eighteenth century should be remembered. The improvement was technical rather than moral. The exciseman collecting an ascertained charge was less burlensome than, if ahmost as mpopular as, the patentee taking " what the market would bear." The limitation of monopoly which resulted from parliamentary government can be studied more effectually in cases where the srstem was retained than in those where it was abolished. There is thus a peeuliar interest in the history of the foreign trade companies and of the Bank of Englanu. These subjects are treated at greater length in a later chrpter. We may notice, howerer, (1) that even where, as in the case of the Last India Company, there were strong arguments on the side of privilege, the privilegeel Company was subject to constant attark, paid very heavily in loribes to members for renewal of its rights, and was compelled on one occasion to incorporate a number of ontsitlers: (2) that in general the interests of the public were preserved either hy fixing at a moderate sum the fee payable for participation in the monopoly, or by the fact that the stock of the concern (Bank of England or Last India (ompany) conld be longht in the open matket, or he the axation of full value for the value comferted as in the catse of the linancial serviees rentered to the State loy the Bank of England.

The monopoly system hat been the most viluerable part of the 
regulation of industry between 1580 and 1620 ; it had, however, been only a small part of the system. There remained the vast mass of general regulations. Such measures as the statute of artificers or the codified Poor law were not directly affected by the constitutional struggle. They did not outrage the beginnings of liberal sentiment which had rebelled against individual privilege. Furthermore, there was no necessary antagonism between them and the representative system. On the contrary it remains a moot point whether the legislature or the executive had contributed most to their existence. Indirectly, however, the Rebellion and the Revolution had far-reaching influence over them, by shifting the lines of least resistance to regulation. Methods of intervention which had been of comparatively small importance became predominant, whilst the favourite devices of earlier times dropped into the background. In the sixteenth century, regulation of internal production by control of export and import trade was not neglected, it was, however, insignificant as compared with inspection and control of the producers themselves. In the eighteenth century the situation was exactly reversed. The dividing line is found in the twenty years between 1640 and 1660. The change was due no doubt in part to the growth in importance of foreign as compared with home trade, the expansion which set in with the Restoration. But even on the eve of the Industrial Revolution the influence which regulation of foreign trade was capable of exerting was not very great. Few articles except luxuries and indispensable raw materials could pay for transport from abroal. The imports composed perhaps one-fortieth of the annual consumption of the country, ${ }^{1}$ and though prohibitions and taxes liept out much that would otherwise have come in, the same was true in the sixteenth century. And in fact in France, which until late in the eighteenth century maintained its industrial leadership over England, internal regulation continued to be of at least as great importance as tariff manipulation. The chief reason of the change in England was probably the decay in the control of local anthorities by the central executive. We have seen that in the sixteenth century economic and social administration passed more and more into the hands of the Justices of the Peace, whose activities were stimulated and guided by the Priry Council. The constitutional

1 The proportion is probably to-day nearer one-fourth. 
changes of the seventeenth century struck at the roots of this system. For the very class of landed gentry which were supposed to be controlled by the executive became, through its influence in Parliament, superior to its supposed master. The effects of this change on the local government of the country have often been pointed out. The machinery for enforcing efficiency and diligence was effectually destroyed, and little of either was seen again until the changes of the nineteenth century. The decay of the powers of the Privy Comeil affected in the same way local administration in the boroughs wherever-and this was the general rule-power harl passed into the hands of a close oligarchy independent of the opinion of those amongst whom they lived, and no $\mathrm{r}$ independent of the central government also.

The same political changes which made internal regulation more difficult facilitated tariff manipulation. So long as the initiative in regulation was vested in the Crown whilst control of the tariff lay in part at least in the hands of the Commons, it was comparatively difficult to use the tariff for any complex scheme of regulation. The Commons could, indeed, be counted upon to prohibit importation of foreign manufactures indiscriminately, but such refined arrangements of import duties and bounties on export as came into favour in the eighteenth century would have resulted in constant friction. The principles of trade regulation laid down by Charles I in 1626 were at least as sensible as any that were either professed or tollowed between 1660 and 1760 , but so long as expenditure was not controlled by the Commons any action of the executive in this fiekl was subject to suspicion. Tariff manipulation seems to have become really important from 1660 onwards. A Dutch statesman observed that " the English, anno 1660, settled their Rates of Customs and Convoy money so well . . . . to favour their inhabitants as much as they coulel, and to burden all foreign Masters of Ships and Merchants. . ." 1 In the eighteenth century tariff treaties, beginning with the Methuen treaty of 1703 , came to rank anongst the chief objectives of diplomatists. The complications of the system are almost increelible to one mnfamiliar with modem French or American practice. Aclassic instance is the following description of a single measure designed to assist one branch of the

"gunted Cumbingham, "Cowth of English Industry and Commerce," ** 1). 201 . 
textile industry: "a tax was laid on foreign linens in order to provide a fund for raising hemp and flax at home; while bounties were given on these necessary articles from our colonies, the bounty on the exportation of hemp was withdrawn. The impoits on foreign linen yarn were withdrawn. Bounties were given on British linen cloth exported; while the making of cambricks was promoted, partly by prohibiting the foreign and partly by giving fresh incentives, though without success, to the mannfacture of cambricks within our island. Indigo, cochineal, and logwood, the necessaries of dyes, were allowed to be fretly imported." 1 The famous Navigation Act of Cromwell, as has often been pointed out, did not differ much from a series of earlier measures, stretching back to the fourteenth century; yet the tradition which marked it as the beginning of a new departure had at bottom a certain truth. From the Restoration onwards the manipulation of foreign trade was the chief method of influencing industrial development.

Besides determining in part the method of economic regulation the political events of the seventeenth century had an important share in deciding its direction. When the power of Elizabeth was at its height, it seemed to English imperialists that their country would reap the principal advantage from the imminent decay of Spanish and Portuguese power in America and in the East. The rapid ripening of constitutional problems under James $I$ and Charles I put an end to that possibility. The naval and military prestige of the country was indeed temporarily restored by Cromwell, but it was lost once more under Clarles II, and meanwhile the rapid growth of Holland and France had raised two serious rivals. Hence the deliberately anti-Dutch policy of the Navigation Act and the chronic war with France in the eighteenth century, together with concentration of effort upon those transoceanic countries in which the power of France was increasing or likely to increase. India, North America, and the West Indies occupied our attention. The Spanish colonies in Central and South America were relatively unimportant. The period of expansion secms to have set in effectively with the Restoration. The weight of evidence is against the vicw that much was due in this respect to Cromwell. On the contrary it seems that the disturbance of

${ }^{1}$ Chalmer's "Estimates," p. 148. Quotecl Hobson, J. A., "Evolution of Modern Capitalism," p. 37. 
property and heary taxation which characterised his rule resulted in commercial depression, whilst the Protector himself did not develop the characteristics of the commercial statesman. ${ }^{1}$

The abandonment under the Restoration of the idealistic bent which Cromwell had given to English policy left room for a detailed pursuit of material interests. The opening years of the reign of Charles II were marked by great activity. His marriage with Katharine of Braganza was the beginning of that quasi-colonial relation of Portugal to England which was perfected by the Methnen treaty. In return for political support and a preference for their wine in England, the Portuguese in 1703 abandoned the protection of their manufacturing industries and allowed much of the carrying trade between their colonial possessions and Europe to pass into English hands. The marriage also gave England in Tangier, and the island of Bombay, keys to the Mediterranean and to India. Charles had opened relations with the American Colonies before his return to England, and the work of settlement was pushed on after his return. He was active also in concluding commercial treaties, whilst at home the newly constituted Committee of Trade dealt with the exportation of bullion, the Navigation Acts, and the tariff, and some effort was made to maintain an efficient navy and to provide convoys for merchantmen as a defence against piracy.

So far he was ready to go in farour of the interests which subsequently formed the backbone of the Whig party. But this economic policy was hardly reconcilable with the political ideals which inclined him to lean upon France. The traders and moneyed men instinctively perceived that France was the chief economic rival of the country. They financed the French wars of William III and Marlborough, and reaped great advantage from the Peace of Utrecht. The position of England in respect to external trade at the beginning of the reign of (icorge I may be summarised as follows:- Cibraltar secured access for her to the Mediterranean; from Ninorca she controlled Spain and the pirates of North Africa: Sardinia and Sicily had been transferred to non-commercial powers (Austria and Saroy). The fortifications of Dunkirk were rased. Bremen annexed to Hanover was opened to the English.

'(p). Cumningham, " (irowth of English Industry and commerce," ** 194. This view is, however, disputed by Ranke and Gardiner. 
Newfoundland and Acalia restricted French expansion in North America, the English colonies were imbued with anti-French feeling. The Portuguese possessions in South America, which had been opened to English commerce by the treaty of 1703, were enlarged at Utrecht. A monopoly of selling negro slaves to Spanish South America was secured together with the right of introducing one cargo per annum. ${ }^{1}$ The work thus begun in the first twenty-five years after the Revolution was soliclified in peace and war throughout the succeeding century. The transoceanic markets open to English manufactures steadily increased in importance; and the commercial relations maintained with them became more and more organised and systematic. These widening markets were one of the chief causes of the revolution in the structure and technique of manufacturing industry at the close of the eighteenth century. The success of British arms during the Seven Years' War in India and North America must have advanced the Industrial Revolution by half-a-century.

There is no reason to doubt that the economic derelopment of England was favoured by forcible entry into distant markets, by the iniquities of the slave trade, and in general by the exploitation of weaker nations. If the English had not forced an entry, the French, the Spanish, and the Dutch would have excluded them by force. Whether anything was gained by the attempts to monopolise these markets, and to secure them as well as the English market for English produce alone, is much more questionable. In particular the jealousy which wrecked the hope of a commercial treaty with France in 1713 was exaggerated and short-sighted. The Tory party, which was in office when the treaty of Utrecht was concluded, did not share the intense hostility to France which coloured the Whig judgment of economic questions. The treaty provided for the resumption of trade between the countries on a basis at least as liberal as that which had existed in 1664. All subjects of either sovereign were to enjoy the same commercial privileges as the most favoured nation. The government, however, after a lengthy controversy, failed to secure the assent of the House of Commons. Petitions against the proposals came from the silk, the woollen, and the distilling interests. The tone of these petitions was as exaggerated as is usual in such cases; their arguments were met and

'See the excellent summary in Bourgeois, "Politique Etrangère" I, 292-4. 
exposed by Defoe and other writers in "Mercator"; but behind the vested interests was the Whig conception of foreign policybased upon active and nourished hostility to possible European competitors. The chief practical argument on this side arose in connection with the Portuguese treaty. In return for an adrantage to Portuguese wine over French in the English market, we had secured entry for English manufactures to Portugal and her colonies. This might be forfeited if French wine were placed on an equal footing with Portugnese. The Tories, on the other hand, though willing to break up the commercial policy of the Whigs, were not prepared to secure for England the adrantages of a simple free trade tariff. They held so much of the balance of trade doctrine that it was difficult for them to answer the positions of the Whigs, viz., that the trade with Portugal was a gain, that with France a loss to England. Their argument that we ought not to refuse trade with France because they were our enemies, though good so far as it went, did not touch the economic case of the Whigs, viz., that we traded with France at a loss.

On the question of fact there seems no reason to doubt the conclusion reached by Adam Smith after careful consideration of all available evidence, that the economic progress of the country would have been more rapid had military and naval success been used merely to secure access to colonial markets on equal terms with other comntries, whilst England at the same time had been made a free island. Towards this view the theory of able statesmen and economists was steadily approximating through the eighteenth century, though the unleavened majority continued to heap the tariff with absurdities, to outrage Ireland, to alienate the American Colonies, and to breed international bitterness. Starting from the possibly partisan Liberalism of the Tories at Utrecht, we find Bolingbroke, Walpole, Shelburne, Burke, the younger Pitt, verging towards a Liberal tariff policy, whilst the arguments of the Wealth of Nations were led up to gradually by a long list of writers from Inm, early in the seventeenth century, to Hume, the personal friend of Adam Smith.

The real problem is not whether the restrictive policy was beneficial, but whether sufficient national spirit to break upother nations' restrictions could have been generated without it. The promise of a monopoly is a simple and tangible gain which the plain merchant 
can understand and fight for-or at least pay others to fight for. Neither his greed nor his patriotism will be so easily aroused by the proposal merely to reduce the foreigner to an equal position with himself, however probable it may be that by so doing he would satisfy at once a greater greed and a larger patriotism.

The ideals which governed the action of the English Parliament from 1660 onwards were but little different from those which had actuated Burleigh. What had altered in the interval were the means by which those ideals could be attained. We have examined above the way in which constitutional changes reacted on economic policy. A further cause of change was the inevitable growth of British as distinct from English sentiment. In Elizabeth's reign the problem of the national economist was to stimulate the productive powers of England to the neglect of all other interests. In the eighteenth century the union with Scotland, the increased importance of Ireland, and of the American Colonies, had begun to work a change. The gradual merging of the English into a British nationalism had commenced, and men were already regarding the Mother Country and the Colonies as a whole whose parts should render mutual service. This, of course, was the ideal. In fact, all that can be claimed is that the dim presence of this conception of imperial unity and common interest in the minds of a speculative minority mitigated exploitation and restriction. In theory one department of production would be assigned to America, another to Ireland, others to England, just as in England and, before England was, in Borough or Manor, this duty would be assigned clearly to one individual, that to another. In practice England took what was agreeable or convenient to herself; Ireland and the Colonies had the leavings. The Colonies might send pig-iron to England, since the using up of timber had made its production here expensive, but they might not manufacture this pig-iron either for the English market or for their own. In Ireland there was worse abuse than restriction, viz., the destruction in the interest of England of existing industries. Scotland was in a position to make terms for her own interests. From the time of the Legislative Union her economic life merged imperceptibly into that of England. Her southern districts shared with the English north the triumphs and disasters of the Industrial Revolution.

The chief concern of statesmen between 1660 and 1760 was, as 
has been seen, in regard to foreign trade. The object was to export as much and to import as little as possible, the idea being that exports created, imports destroyed, employment. Granting that a commodity must be imported, it was preferable that it should come from an English colony in an English ship. Hence the colonial import bounty and preference systems and the persistent navigation policy. Opinion differed on the policy of exporting bullion, though in practice it was necessary to permit it to the East Indies. The theory advanced by Mun that the goods procured by Eastern trade would bring in a balance of money from Europe came to be accepted, but it was generally hoped that some day a good market for English cloth would be discovered in the East which might obviate export of bullion. Many men would no doubt have crudely stated the object of foreign trade to be the attainment of supplies of bullion; but behind this statement there would have lurked the idea that an increase of currency would increase employment. This view is, of course, fallacious, but it is a different fallacy from identification of wealth with the precious metals. The ideal is a productive, efficient, and fully employed population, not a heap of treasure. As might be expected, attention was concentrated principally upon the problem of manufacturing development; there seemed more room for increase in export of manufactures than in export of raw materials or food - besides, it seemed more ideal to keep food and raw materials at home and use them as a basis for further export of manufactures; thus we find the policy of restricting exports of wool maintained in the interest of the textile industry. In regard to food the position was complicated by desire to produce the maximum of corn-growing. Tillage was valued as provicling a peasant population sufficiently strong and healthy to make good soldiers; and further as victualling the country against war and famine. Doubtless also a tradition in favour of tillage survived from the hardships of the enclosure movement in the sixteenth century. Hence the adoption at the Revolution of bounties on corn exports and their maintenance during the eighteenth century: it was clained that the system extended production and steadied, if it did not lower, prices.

But although the protective system of the Whig period was certainly intended to benefit the nation as a whole, the precise way in which the wage-earner was protected by it becane constantly 
more cold and abstract. There is all the difference between protective legislation, which aims at increasing employment generally, and such legislation as the Statute of Artificers and the Elizabethan Poor Law code, which aims at succouring in detail the individuals who are oppressed or unfortunate. It is true that this legislation remained on the statute book, but as has been seen the constitutional change had broken up the machinery by which it was intended to be enforced. We find in consequence on the one hand a commencement of laisser faive in practice, and on the other an inefficient administration calculated to breed in observers a prejudice in favour of laisser faire. The assessment of wages by Justices of the Peace seems to have been widely practised under the first two Stuarts, though evidence on the subject is fragmentary even for this period. The period of Revolution and Interregnum evidently struck a heavy blow at it, though one attempt was made to enfore it generally. Under the Restoration there was some revival of the practice, but after this period it seens to have had little vitality outside Yorkshire. In the eighteenth century the system was used occasionally to meet exceptional cases, but had evidently ceased to be a part of the normal duties of Justices. It should be noted that even at the beginning of the seventeenth century assessments once made were continued in some parts of the country for years together, instead of being revised annually in accordance with plenty or scarcity, and it is probable that the assessment often meant little more than an enclorsing by authority of rates of wages fixed by competition and custom. Another provision of the Statute of Artificers had more vitality. At the close of the eighteenth century, when assessment of wages was regarded as a legal curiosity, restriction of crafts to men who had served an apprenticeship was a well observed custom in many trades. It was, however, little more than a custom even in the seventeenth century. Its prevalence is shown by the fact that in 1654 the restrictions were suspended in favour of soldiers who had served in the parliamentary armies. Its frequent breach is clear from records of litigation. The multiplication from 1689 onwards of new manufactures which had not existed in 1563, and which consequently remained outside the scope of the law, steadily increased the area of unregulated industry. Active supervision of production, whether by officials or delegates of the central government, or quasi-gild organisations and companies, 
broke down at the time of the Interregnum, and never recovered much ritality. The official gauging of cloth, however, continued down to the Industrial Revolution. There were complaints during the Interregnum that the collapse of inspection caused a deterioration in the quality of English manufactures, but the growth of the system of trademarks seems to have provided a remedy for this eril if it really existed.

In regard to the Poor Law a similar distinction may be drawn between the period before and the period after the constitutional struggle. The break-down of the machinery of administration removed that pressure from the centre which is essential to effective handling of this problem. The resultant evil was so considerable and obvious that legislative amendments to the system were constantly carried in Parliament from the Restoration onwards. The most important Acts were those of 1662 and 1723. The former aimed at checking the tendency for vagrants and loafers to gravitate to " those parishes where there is the best stock, the largest commons or wastes to build cottages, and the most woods for them to burn and destroy." It gave a parish power to remove, within forty days of his arrival, any new-comer who seemed likely to come upon the rates. These powers were so extended by the subsequent legislation of "Settlement," that the law presented very serious obstacles to the mobility of labour and involved many parishes in tedions and wasteful litigation. The Act of 1723 was intended to provide an easy solution of the problems of providing employment and testing genuine destitution. Parishes and unions of parishes were empowered to erect houses for lodging and employing the poor, and to refuse relief to persons who would not enter the house. The system was widely adopted, and its history shows strikingly the evil which results from lack of central control. Houses which were started on commenrlable lines by indiridual enthusiasts lost their usefulness as these individuals died or lost interest in the scheme. There were enormous differences between the quality and methor of relief provirled in different localities. The system of contracting witl individuals to feed and clothe the poor-the contractor being paicl a sum down and allowed to sell the goods produced by pauper labour-led to grave abuses.

() the misery of large sections of the working classes during the seventeenth and eighteenth centuries there can be no reasonable 
question. The West Riding cloth industry, describet by Defoe early in the eighteenth century, was quite evidently one in which the position of the labourers was unusually good, yet even here we read that " all were employed from the youngest to the oldest. scarce anything above four years old, but its hands were sufficient for its own support." " The fact of the irregularity of employment during the seventeenth century," writes Professor Hewins, "is clear." And again: "there is reason to believe that insecurity and irregularity of employment were the normal condition under which artisans and agricultural labourers worked." 1 The evil of truck was widespread. There was no limitation to hours of work, no attempt to enforce sanitation, whether in cottage or workshop. The commercial middleman who went round the country distributing raw materials and collecting the finished product had an almost absolute control over the lives and fortmes of his employees. He had no expensive plant which they conld leave idle by striking. If they allowed him to pass on with his order they knew not when another would come their way; and they were too scattered and too much held down by law to practise organisation on any considerable scale. There were, on the other hand, compensations. The industry of England was largely rural, and in the rural districts a large proportion even of the industrial wage-earners remained masters of $l$ enough land and common rights to add appreciably to their income. Conditions were at their worst in the large townsespecially London. It was experience of London life which drew from Fielding his famous aphorism on the poor, "All will allow that the poor are now ill-provided for and worse governed... their sufferings are less observed than their miscleeds... they starve and freeze and rot among themselves, but they beg and steal and rob among their betters."

A most significant incident of these centuries was the growth among the well to-do of a feeling that the poor were dependent upon them. The boon of employment seemed to make the rentier "productive," the labourer " a parasite." In this way was prepared the attitude of mind which demanded that wages should be determined rather by the needs of the labourer than by the value of the work which he performed. We shall find Parliament at the close of the eighteenth century preferring to subsidise wages from

1 Hewins, "English Trade and Finance," p. 92. 
the rates in proportion to the size of each labourer's family when confronted with the demand that Elizabethan wage assessments should be revived. It is this element of contemptuous pity, the lack of sympathy and kesire for justice, which give to eighteenth century respectability and its survials to-day, their peeuliarly somr taste.

Consiker the following hrmm of Dr. Watts:

Whenc'er I take my walks abroat.

How many por I see!

What shall I rencler to $\mathrm{my}$ G d

$\mathrm{For}$ all His gifts to me?

How many children in the street

Half naked I lehold!

While I an cluthed from head to feet.

And cover'd from the cold.

Are these Thy farours day loy day

To me above the rest?

Then let me kre Thee more than they.

Anrl try to serve Thee best.

The Elizabethan (under pressure from the central government) would have taught his children to put an end to poverty by enabling these "half-naked children" to clothe themselves. England unler the Tudor absolutism acquired a sense of social solidarity. All classes were the members of one body, of which the Crown was the hearl. This conception, and still more the machinery by which it conld be expressed, perished in the constitutional struggles of the seventeenth century.

The victory of Parliament must be credited with stimulating the progress of economic discussion. Throughout the seventeenth and eighteenth centuries a flood of pamphlets with occasional works of a more serions nature was poured forth. They were written for the most part by practical men and on practical subjects, even when the authors were philosophers or men of leisure. From the point of view of the historian of economics, the most interesting side of the writings of this period is the gramal approximation to perception of mity in comomic phenomenta If we take, for instance, the subjert of foreign tracle, we can trace an increasing sense of the interation of tratle with one country upon trade with another, of the reciprocal influence of exports and imports, and so on. The more rigid adterents of the theory of balance of trade held that note should be taken of the state of trade between England 
and each country by itself. Against this riew it was pointed out that an unfavourable balance on one trade might be the indispensable condition of a favourable balance on another. Thus the export of silver to the East in exchange for commodities was an indispensable condition of obtaining silver from Europe in exchange for commodities. This perception of the relation between trade with different countries left the general theory of the balance undisturbed; in other words, whilst it led to the belief that all exports and that all imports which were useful to the production of exports should be free, it did not disturb the view that taking the trade of a country as a whole the greater the balance of exports over imports the greater the advantage to the conntry. That riew we finsl strongly expressed in Locke. As long as it remained it was, of course, desired to exclude all commodities which $(a)$ conld be prodnced at home, (b) were not required for re-export. In pressing further the study of foreign trade, eighteenth century thought made an important combination of two principles already developed in the seventeenth -viz., the more liberal theory of the balance as outlined by Mun and the quantity theory of prices. If it was only desirable to exclude those foreign commodities which had no beneficial reaction on export trade, the quantity theory of prices could be applied to show that as imports of silver raised prices in the country to which they came and thereby restricted its exports, it was at least as desirable to exclude silver as to exclude any other commodity.

A more fruitful development was the gradnal perception that labour and capital could be diverted by tariff manipulation from one employment to another but could not be increased, that the real problem was not to add to the industries of the country but to promote those industries which would give the best return to the labour and capital employed in them. Such a view, however, could hardly be worked out until men had cleared up their ideas as to the part played by labour in the production of wealth. We have seen that according to the medieval view, the just price of labour was supposed to be determined not by the value of the work done but by the class standard of the worker. Eighteenth century opinion presented a bastard travesty of this view in the belief that employment and alms were identical in nature. In neither case was there perception of what seems self-erident to many to-day, that the work of one man is more valuable than the work of another, or that 
an indiridual will do more raluable work at one time than at another. The ideal was that an individual should employ himself, no matter how, and be paid a sufficiency. It is, of course, true that in the eighteenth century, and for that matter much earlier, public opinion had demanded encouragement for some industries in preference to others-e.g.. manufactures, shipping, tillage-and Eenerally had enjoined the restriction of imports. but at the back of these demants was almost always the feeling either that the industries in question were important on non-economic grounds. or that they would employ a greater number of individuals than the industries which they displaced. The idea that a greater total of economic wealth will be produced by turning a certain quantity of labour into one emplosment rather than another is hardly found before the eighteenth century. Even after Atam smith, e.g. in Ricardo, traces of the old influence remain. The theory that the cost of producing a labourer determines his competitive earning power may be lescribed as an attempt to rationalise the medieval riew that the just wage was determined by customary class stanclards.

On several other questions a similarly increased perception of the unity of economic hemomena and the importance of secondary effects may be discorered. In the literature on Interest the centre slifts grarlually. On the one hand the feeling of a moral clistinction between loans ant other serrices, personal or physical, continued to decay. On the other hand it was seen more and more clearly that the rate charged is determined in each case, not solely by the avariere of the lemeterand the necessitrof the borrower, but by market sulply of and mated demand for reaty money. We find further attempts to connect the rate of interest on loans with the rate of interest obtainable in other investments. Thus Sir William Petty hell that "interest on the best security could not exceed the rent which would come from a similar sum invested in land." 1 On fiscal questions again we lind men working back from the extemal phenombena of taxes towaris the central problems of incidence, and of the effects of taxation on industry.

1he progres of enoming studies was no doubt assisted by the general scientific mosement of the seventeenth century. That influnere, howerer, slomld not be exaggerated, for as has been

' Cumninglam. " Cimwh of English Industry and Commerce," ** p. 385. 
pointed out most of the pamphlets were the work of practical men, and were the ontcome of the free discussions of economic questions which the parliamentary system called for. Some of these practical men brought a considerable knowledge of facts to bear upon the problems which they discussed, thongh it is doubtful whether any question was investigated so thoroughly in the serenteenth and eighteenth centuries as the Poor Law problem had been in the reign of Elizabeth. Towards the close of the seventeenth century we reach the beginnings of statistical investigation. $\ln 1688$, Gregory fing estimated the population at five and a half millions. The data for such studies were, however, too inadequate for the conclusion to have much practical significance. 


\section{CHAPTER II}

AGRICLLTLRE, INDUSTRY, AND FOREIGN TRADE

Ar the close of the sixteenth century an equilibrium had been reached in the organisation alike of agriculture and the manufacturing industries which lasted with little clange for more than a century and a half. In agriculture the limits of advantage in extending pasture had been reached, and enclosure of the common fields matle slow progress over the greater part of the country. As the population increased, the settlement of waste lands proceeded, but except in the neighbourhood of London the profits to be made by rapidly increasing the supply of food were not very great. The constituents of agricultural society were almost the same on the eve of the Industrial Revolution as they had been in the reign of Elizabeth. The steady demand for estates, especially after the Revolution, on the part of men who had made money in trade seems to have slowly reduced the number of frecholders. The same cause, together with the growth of population and the settlement legislation, increased the number of landless labourers. There was, however, nothing cataclysmic about either morement. At the Revolution, King reckoned the number of Yeomen free-holders at about 180,000 , the number of farmers at rather less. He estimated the trital of the Agricultural Classes (Freeholders, Farmers, Iabourers, Out-servants, Cottagers, Paupers) with their families at four and a quarter millions. If we deduct $1,800,000$ for the two first classes we are left with a total of roughly 2,500,000, which will inchule, of course, a large number of families whose chief occupation was manufacturing in some domestic industry.

I similar equilitrim had been reached in the position of these inclustries. There was no prospect of any considerable change of structure mintil eitleer a teclunique reguiring great outlay on fixed capital or improved methods of commmication were attained. And in fart at any period between 1600 and 1760 one and the same organisation of the principal industries appears. The mass of producess, whether in town or combry, worked in their own lemes, and were connerted by middlemen with the producers of the raw material and the consumer. Minor variations from this 
general type were numerous: they were, however, seldom of much importance. The domestic worker might be assisted by his wife and children only, or by journeymen and apprentices. He might receive raw material from the same man who took off his finished article, or from another middleman, or direct from the producer. The number of hands through which the raw material passed before it reached him, or the finished article before it reached the consumer, might be greater or less. The general system stands ont listinct on the one hand from the purer form of gild where craftsman dealt directly with the consumer or sold in open market to a trader of the same social standing as himself, and on the other hand from the factory system of modern times.

Some of the characteristic aspects of this system have been glanced at above. The scattering of workers through the country districts made systematic regulation and inspection impracticable in the long run. There was a maximum of opportunity for fraud on both sides. The worker could spoil or embezzle the raw material in the absence of his employer, or pawn the finished product, or turn out bad quality. The employer could squeeze the worker, or pay him in goods of bad quality. Regulation of the hours or conditions of work was impossible. Nevertheless the position of the worker was safeguarded in the rural districts by the possession of land, or at least use of commons: in the towns and the more localised industries by incipient trade unionism. In industry, as in agriculture, a very gradnal movement can be discerned. Industries which in 1600 had not yet reached the condition indicated gravitated slowly towards it. There was slow movement in the direction of the factory system. But as a whole the period is not one of transition, but of the ripening of forces which, at its commencement, were already well established and clearly defined.

Of the three classes-landowners, yeomen, and farmers-who directed English agriculture, none was likely to introduce improvements rapidly, and in fact technical progress was exceedingly slow. As regards the first it is significant that although they had everything to gain from improved communications and were all powerful in both houses of Parliament, little was done in this direction until the manufacturing interest took the matter up in the second half of the eighteenth century. As a class, they have always been 
inclined to accept the income normally derivable from their properties as a settled quantum-administering it upon sound conservative principles, but showing little skill in devising methods to increase it or in resisting economic forces which tend to reduce it. The yeomen and farming classes, before the Industrial Revolution, were in many respects admirable. But they possessed neither the capital nor the mental alertness which farour technical advance. Like the landlords, they suffered from, if they also gained by, hereditary succession.

The difficulty of agricultural adrance may be illustrated from the partial failure of the attempts repeatedly made in the seventeenth century to reclaim the fen districts in the Eastern counties. This work was carried ont for the most part by "adventurers," who brought capital into the business. In 1601 a statute laid down the general principles upon which they might proceed, and large sums were sunk in consequence. The significant features of the move ment are (1) the part played by organised capital subscribed by syndicates of speculators foreign to the district; $(2)$ the use made of continental - especially Dutch-engineers and engineering practice: (3) the failure to estahlish satisfactory relations with the existing population of the districts operated. The riots of the fenmen were assisted by the outbreak of the Civil War ; they continued long after the conclusion of peace, and did not cease entirely until 1714 . The batile between them and the adventurers was drawn. Much of the land which had been reclaimed relapsed again to fen, and further progress was delayed until late in the eighteenth century. Still more interesting is the long neglect of the use of turnips and artificial grasses as field crops. These were recommended by standard writers on husbandry under the first two stnarts; there were treatises also on gardening, and on reclaining forest; and new kinds of manure were explainerl. In the same period the patent records show a number of imporements in agricultural tools and machinery. Actual progress remained very slow. For this there was some excuse luring the revolutionary period in the pressure of political problems and the inserurity of property; but the first half of the eighterenth rentury has little to show bevond a handful of great experimentalists crying in the wilderness. Jethro Tull, Townshend, and bakenedl slonwed what was possible, but there were few to follow them. 
Governmental action in the furtherance of agriculture was alnost restricted to manipulation of the tariff and of the fiscal system : and it was not until the close of the eighteenth century that a public office was instituted to collect and disseminate information on agricultural topics. In regard to the tariff, the general rule was to encourage export and restrict foreign competition. The rent of land was regarded as one of the best criteria of national prosperity, and a mistaken deduction was drawn from this principle in favour of raising rents artificially. In earlier chapters we have watched the gradual transition from a policy which aimed simply at providing cheap corn for the consumer to the protection of the producer. A further step was taken in 1689. when a bounty on export was offered. Considerable duties on imports of agricultural products had been imposed under the Restoration. It must. however. be renembered that the export bounty on corn purported to assist the consumer by making it profitable to sow so great an acreage that there would be no famine, even in years when the harvest was a failure. It was claimed that the bounties reduced price fluctuations, and actually lowered the average price by increasing the quantity produced. As regards the latter point it is true that the price of corn was on the whole lower in the first half of the eighteenth century than in the previous fifty years. But Adam Smith pointed out that a similar fall in price occurred in France, where. until 1764. the usual policy was to prohibit exportation. There is little sign of the bounty acting as a stimulus to improved methods of production. yet unless this was the case. it is hard to see how an increase in the area under wheat could fail to raise prices in normal years. Nor is it easy to believe that the bounty steadied prices. The question cannot, of course, be decided absolutely, but whilst theoretical considerations are on the whole against the view, no support for it can be drawn from the study of price statistics. If the Windsor corn prices for the thirty years before 1689 are compared with those for the thirty years after that date. the difference between the extremes of high and low prices are almost identical for the two periods. In the former we have $f 314$ s. in 1662 and $f_{s} 15$ s. in 1687. in the latter $f_{3}$ 18s. in 1709 and $f 16$ s. in 1706. In spite of the power of the landlords in Parliament. their interests were generally placed second when they seemed to conflict with those of the manufacturers. Thus the export of wool was 
prohibited by statute from the Protectorate onwards. Adam Smith doubted whether the prohibition affected the quantity of wool produced. The price of the best wool in England was lower in his day than the price of inferior qualities in Amsterdam, and he believel that the English farmers revenged themselves by charging a higher price for mutton. It is worth noting that the sheep-breeders of the eighteenth century aimed at increasing the wight of meat rather than the weight of wool.

In taxation it cannot be charged against the landowners that they made any active attempt to rid themselves of their burdens. It was. for instance. never seriously proposed to take the burden of the rates off land. There was, however, a persistent feeling in Parliament that taxation of land was undesirable. When the feudal ches were abolished at the Restoration. they were made good by an excise, not by a permanent imposition of the land tax; and it is significant that no reassessment to the land tax was made after the end of the seventeenth century. There was no ungentlemanly stampede, but the power of evading taxation was almost imperceptibly utilised.

The progress of industrial technique during this period was still very largely due to foreign immigration. A stream of French Huguenots. after the rerocation of the Edict of Nantes, founded many new industries. German refugees arrived in 1709 and 1732 , and more French in the middle of the century. Apart from the effects of political or religious persecution, England, from the sixteentl century onwards, offered a field to the foreign "expert" who could introduce and secure a patent for some new process or mechanical device. The statute against monopolies of 1624 had carefully safeguarded the elain of the inventor or introducer of new methods, and the patent records from the beginning of the century show that attention was turned increasingly to technical improvements. It does not form part of our plan to attempt any detailerl study of these improvements. In general, as might be expected. they implied increasing capitalistic control of industry. Amongst the refugen from France and ciermany were a minority of well-to-do and experienced employers. The more humble took service either with then or with English capitalists. The French or Cerman craftenan, ignorant of the linguage and customs of the combtry. and with no reserve of walth. Was not in a position to 
set up in independence, even if he had been independent in his native country. The elaboration of new processes in many cases ralled for considerable expenditure of capital on experiments, or, where this was not the case, at least by increasing production, made capitalist organisation more profitable. The introduction of the flying shuttle in weaving, for instance, threw the weavers ahead of the local supply of yarn, and caused it to be supplied to them from greater distances.

As a preliminary to the history of technical improvements during the Industrial Revolution the conditions of two groups of industrytextile, and mining and metallurgical -in the previous century and a half are specially deserving of consideration. The textile industries, as far back as history can follow them, have been distinguished by the use of mechanical derices. A primitive loom is already quite a machine, whilst a potter's wheel or a smith's bellows are little better than tools. There were accordingly in the sixteenth and seventeenth centuries numerous anticipations of the great development of textile machinery which inaugurated the Industrial Revolution. We may notice the use of fulling and gig mills, of a mechanical shearing process, of frames for knitting stockings, of machines for weaving ribbons. In the first half of the eighteenth century we have the invention of the flying shuttle, which could be adapted to all kinds of weaving, and doubled the output of the worker; and the importation from Italy of designs for water-driven machinery to throw silk, which was set up in a considerable " mill" at Derby. There were, however, very great obstacles to the rapid adoption of technical improvements throughout the whole of this preliminary period. In the first place rested interests resisted the encroachment of new processes; in the second the possiblity of greatly increasing production in the chief textile industry was limited by inelasticity in the market of cloth and in the supply of wool. The more rapid progress of the cotton industry in the eighteenth century was due to the fact that these difficulties were non-existent or relativlely slight.

The opposition to the use of machinery, whether by rested interests or by the Gorernment, was perfectly reasonable. The objection felt was not to change in itself but to such change as sacrificed the justifiable expectations of one group of producers to the interest of another group or of consumers. This is evident 
from the fact that an invention which did not threaten to displace existing labour was always regarded favourably. The inventor in such a case might comt upon the grant of a patent if he secured the ear of an influential man, even before the patent system was regulated by statute. Similarly the refugees who introduced the cloth-finishing processes into the comntry were on the whole welcomed by the Govermment and by public opinion in general. There is no doubt, however, that the limits imposed on enterprise by regard for existing interests - there being no settled plan or policy for compensating those interests-appreciably hindered industrial progress. It is not, indeed, likely that many machines were actually kept out of use. Elizabeth might refuse the present of a pair of stockings knit by machinery, but the stocking-frame had "come to stay." Tet the system doubtless discouraged many who would otherwise have thought out improvements, and made the adoption of new methods when discovered much slower than it would otherwise have been. It should be noticel that opposition to an improvement was comparatively small if there were reasonable prospects of a rapid extension of sales of the commorlity affected. In this respect all the minor textile industries, cotton, linen, and silk offered a more favourable field to the inventor in these centuries than did the staple wool. In regard to wool there seemed little prospect either of extending the market or securing an additional supply of the raw material. The cloth industry was finnly established over a great part of Europe, and almost everywhere the Emopean powers were intensifying their protective systems. On the other hand, on accomnt of clinatic conditions, there was no great market for chothe either in the older American colonies, or in Persia and India. The poor marlet for cloth was a favourite objection to the Indian trate, and the search for a North-west passage was instigated by hope of discosering an easy ronte to the temperate provinces of China where doth womkl setl. There was, therefore, some exanse for the anxiety of the Govermment when the eloth industry wats threatemed, either with cheapenipg of the cost of production, or with competition from Treland or the Colonies, or with a shift in consumers' demand from eloth to some other textile. Those who had most capital invested in the industry probably molerstood to the full the delicacy of the situation. It is 
noteworthy that the districts of the west, where capitalistic organisation had made most progress, were far slower in introducing labour-saving derices throughout the eighteenth century than the West Ridling of Yorkshire. The West Riding clothier who worked with his family adopted the flying shuttle and the spinning jenny, which enabled him to increase his family output. The employers of the Western Counties, few in number and no doubt formulating a class policy, probably believed that a rapidly increased output of their fine cloths would spoil the market, and refrained from pressing the new methods upon their employees.

The relations between the cloth and other textile industries were a continuous source of difficulty, for whilst cloth was entirely unsuitable to some purposes, and some quantity of linen, canvas, and silk was therefore desired, there was also the fear that their consumption might in other cases interfere with the sale of cloth. Thus the attempts to encourage native production of linen and silk without thereby interfering with the nuarkets of the cloth industry resulted in most complicated regulations as to what materials might be used for stated purposes, and also an expensive export bounty system. The cloth industry early recognised in cotton its most dangerous competitor. Pure cottons could not indeed be produced here, for English spinners did not possess the skill to produce a warp of sufficient strength; but in the reign of Amne the trade in imported calicos, which were printed in England, expanded rapidly at the expense of woollen hangings and dress fabrics. In 1720 their use was prohibited in England, whether printed here or in India, and the printing industry was confined to linen and mixtures of cotton and linen, until the rise of machine spinning in the cotton industry half-a-century later.

It is probable that the adoption of mechanical improvements in the cotton industry was hastened by the knowledge that the raw material could be obtained without difficulty, and that the market for the finished article was almost limitless. A large sale was assured both in tropical and temperate climates, and though the native producer in India might well have urged the iniquity of his uncompensated destruction, India, after the campaigns of Clive, was not in a position to enforce the will of her vested interests. The English woollen industry could and did urge the danger that some of its products would be replaced by cotton, but a valid general 
answer could be given in the prospective expansion of English cotton exports. The two industries were not so dissimilar as to make the transference of labour from one to another impossible.

Throughout the textile industries there was a tendency in the seventeenth and eighteenth centuries for the weaver to outstrip the supply of yarn. This tendency was accentuated by the gradual adoption of Kay's flying shuttle after 1733. It was, therefore, towards spiming that the attention of inventors and speculators was chiefly directed. The problem was partly solved between 1730 and 1740 by the joint efforts of Ilyatt and Paul, and a spinning mill was established at Northampton by Edward Cave, who bought their jatents. The motive force was water. Carding as well as spinning were done by machinery, and as many as fifty hands were employed. The undertaking was not a success funancially, though it continued to operate until 1764. The ideas of Wyatt or Paul (it is uncertain which contributed most) were turned to better account by Richard Arkwright.

If improvements in the textile industries were likely to be resisted by the Government there was no such opposition to the conrse which mining and metallurgy were destined to follow. The importance of timber as material for ship-building made its use as fuel objectionable. Any inventor who could either improve the methods of coal mining, or show how coal could be used as a substitute for timber in industrial processes. was regarded as a public benefactor. He would, of course, be liable to attack from rested interests, but other things being equal all Governments would support him. In regard to the production of coal and mining generally, as the surface outcrops were used up problems of drainage and mining engineering became more and more pressing. Where the shafts were sunk in hills, the nethod of cutting adits from surcessive levels to the side of the hill was adopted; but this plan was, of course, only applicable in cases where the workings lay higher than the lowest exposed surface near them. As the slafts deepened, fewer and fewer fulfilled this condition. The water was got ont by promps and chains of buckets worked by hand or loorse labour, but from the end of the seventeenth century steam purer became more and more common in the mines. Sarery"s "Fire Engine," patented 1698, was intended by the inventor to clear mines of water, and 
though exceedingly defective. was used for this purpose. His contemporary, Newcomen, made a considerable advance. His engine held the field for mining work until Watt had perfected his improvements. The demand for pumping engines was produced chiefly by the increased demand for coal; and this again was largely due to increased use of coal in smelting iron. It should be noted, however, that many other industries consumed increasing quantities of coal-c.g. glass-making, ceramics, brickmaking, and all the industries of metal working. The domestic consumption also increased rapidly. The output is sidil to have risen from 2,612,000 tons in 1700 to $4,773,000$ tons in 1750 . The increase after that date was still more rapid.

Coal had been used for many centuries in working iron, but it was, in its natural state, unsuitable for smelting iron ore. It gave off gases in combustion, which, combining with the metal, impaired its quality. Hence the substitution of coal for timber could not be carried out until a cheap and effective coking process had been discovered, and the difficulties of using coke instead of charcoal solved. It is probable that the German adventurer, Sturtevant, who received a patent in 1612, was experimenting on these lines, and that Dudley, whose work began in 1619, had solved the problem. If so, the accident of the Civil War delayed the development of the industry for a century. Dudley was a royalist, and was ruined by the war. The Government of the Restoration did not help him, and he died keeping his secret. He had actually produced iron at less cost than was possible with the older processes. His original works were ruined by floods, and he suffered also from the violence of competitors. Great progress was made between 1709 and 1760 by the Abraham Darbys, father and son, by Ford, and by Reynolds, at the Coalbrookdale Works.

It is in mining and metallurgy that the earliest examples of the large "works" are discoverable. We have seen something of this as far back as the sixteenth century. The Annual Register of 1769 gives an account of a copper mine in Staffordshire which was supposed to bring its owner, the Duke of Devonshire, a clear $\{8,000$ per annum. This enterprise was very considerable. Sixty men worked at the actual extraction of the ore. It was raised by handwinch to the terminus of an adit, and despatched on waggons 
whose wheels ran in grooves. The ore was broken by men, and further broken and washed by women. Three hundred men, women, and children were emploved, their ages ranging from five to sixty. The organisation of mines and of iron works must have been generally on a considerable scale. The tendency was for the most important inventions and improvements to be struck out and elaborated in works which already enjoyed a certain prestige. Experiments in iron production could not well be carried on without claborate plant. The method of the investigators was still largely empirical, and laboratory work required to be backed by workshop practice. It is difficult to deternine how close was the connection between the progress of invention and the new scientific movement of the serenteenth century. In the case of the steam engine a comnection is clear, and it seems erident also that Dudley had access to the best thought of his age; ret on the whole until the close of the eighteenth century the debt of industry to science was surprisingly small. It should, howerer, be remembered that science offered no career, and that men who now might drift into research, drifted instead into industrial alchemy. Such a man was Josiah Wedgwoor, who was apprenticed to his brother in 1744, and set up for himself fifteen years later. His capacity as an experimental chemist was almost as striking as his organising ability. The great interest in the history of the period is the change in opinion which turned such men as Dudley and Wedgwood from the search for the philosopher's stone to the solution of humbler technical problems. This change was gratually brought about by the fact that the diffurulties of marketing a large ontput, and of large scale organisation, had been so far osercome that it was cridently worth while to think ont improved methods of production. Lntil these prediminary steps hat been taken, attention might well be confmed to the transmutation of metals; for gold and silver alone could be disposed of in unlimited quantities. It would indeed be absurd to suggest that all chemists reasoned in this way, but the explanation of the grarluat relinguishnent of eatrele for the stone must be songht in this sratual opening up of new fieldsor the profitable application of new knowlerge.

The deretopement of the organiser of latge scale prochetion

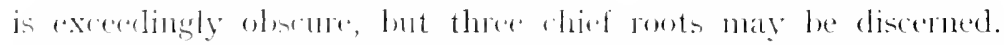
(i) Running back to fordatism and uniting ultimately with the 
system of manorial demesne farming, we may trace the "bailiff" or " steward " organisation of mines, ironworks, etc., on the estates of great nobles. This system, in spite of its obvious defects from an economic point of riew, was still strongly represented in the eighteenth century. We may probably connect with it the surviral of quasi-servile conditions in the Scotch mining districts. It was, however, clestined to give way to the plan of leasing working rights in return for rovalties, although it should be remembered that even where this system is adopted some part of the capital required is often provided by the owner of the land. (2) Leasing of working rights to speculative adventurers has also a long history. Examples of it are frequent in the Middle Ages, especially in connection with the Crown rights. As the former type of organisation merges ultimately with bailiff farming of the demesne, so does this with financial enterprise and the beginnings of political banking. A financier would adrance money against the right to receive dues from an unorganised mining population, and gradually the organisation of the industry would pass into his hands. The fifty years at the close of the sixteenth and commencement of the seventeenth centuries, during which the patent system culminated and declined, seems to have witnessed a great development of this system. Sir Walter Raleigh's patent for tin may be mentioned. When attacked in Parliament, he claimed that his organisation of the business had prevented fluctuations in employment, and maintained good wages for as many miners as chose to apply for work. ${ }^{1}$ Here, indeed, we have the regulation of an industry rather than the organisation of a business, but the two shade into one another imperceptibly. (3) In many inclustries the merchant capitalist developed into, or was superseded by the industrial capitalist. The evolution can be traced from the mere merchant who buys the product and markets it, through intermediary stages where he $(a)$ provicles raw material, (b) employs upon a stock of raw material a succession of specialised craftsmen to perform successive processes, (c) owns the tools or machinery used by the workmen in one or more of these processes, and $(d)$ has one or more process carried on in a mill or workshop of his own, to $(e)$ the final appearance of the factory system.

We have seen that at the close of the sixteenth century the foreign

1 We may compare the arguments often advanced in favour of trust organisation in the present day. 
trade of the comery was passing into the hands of merchant companies, each of which was privileged exclusively with regard to a certain region. The force which erolved this srstem was the desire of established merchants to win a legal basis against the competition of newcomers in the field. Such a desire is, however, a normal constituent of industrial life, and does not by itself explain the acquiescence of the Gorermment. For there was here no question of so ordering competition as to secure good quality and fair prices, or prevent irregular emplosment within the country. Nor was there, again, at least in most cases, any feehing that the company form was necessary in order to further trade, for the market had usually been opened up by private initiative. The foreign trade companies were in both respects at least less obvionsly useful than the industrial companies within the country, and yet the former retained their importance longer than the latter. If we return for a moment to the decay of association in domestic trade we shall see the grounds upon which a lemand for company control of foreign trade could be basen. The nation had become homoseneous. Indiriduals enjosed, in theory at least, something like equal rights. Common institutions transcending class and local divisions made individual differentiation more and more possible. But the unconscious recognition of the binding forces of society still ceased at the coast. The Englishnan ont of England, in his dealings with foreigners, and even in his dealings with other Englishmen, followed anotler code, or rather was less bound to any code at all. This would have been by itself of emparatively small importance. If the state had been in a position to police the seas and maintain letailed relations with other comntries by a diplomatic and consular serrice, there would have been no difficultr. At the time this was imposible: the national rerenue could not have borne the expense entailed "ren if the political organisation of the country had been arlapted to the astumption of this new work. It could be urged that onme form of organisation was needed to stand between the English and the states with which they traded, to obtain privileges and porotedion, and to prevent artions by indiviclual traders which might ruelanger the livelihoud of all. I In most eases the constitu-

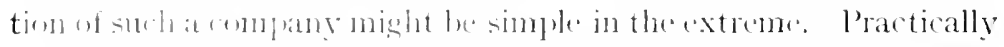

Thus fhe: liast India Company sutfered from piratical attaclis ly interkping Enchinhen on Indian subjects. 
all that was necessary was to register all traders to a particular comntry by requiring them to pay a small fee to a common company. The governing body could frame the necessary regulations and negotiate with the foreign power for privileges to be enjoyed ly all in common, and discipline could be maintained by the threat of exclusion from the benefits of the association. In other casts more seemed necessary. If the royages entailed were very long and risky, and the civilisation of the country in question defective, or widely different from that of Europe, it was (lesirable for the company to command ant use larger funds than could be porided by entrance fees. The establishment and maintenance of factories and a permanent staff in the foreign country, the fitting out of sufficiently large and well equipped ressels, the duration and risks of each renture, could be better dealt with by a closer association. According to the conditions of trade with different countries we find, therefore, two distinct kinds of association developed, the Regulated Company on the one hand, the Joint Stock on the other. Of the first kind, the Ierchant Adventurers at Hamburg, the Eastland or Muscory Companies, the Turkey (Levant) Company, were the most important; of the second, the East Indian, the African, and the Hudson's Bay.

The theory of the Regulated Company was liberal, but in practice it often became exclusive. This might happen in one of two ways. Either the entrance fee might be raised so as to constitute a perceptible tax on outsiders, or the arrangements for common sailings, etc., might be manipulated by a gorerning clique of merchants to their own advantage. One or both of these practices occurrerl in the history of every regulated company. The demand of their opponents was not, generally speaking, that the companies should be abolished, but that they should be thrown open. An experiment in unregulated trade was tried under the Commonwealth, but soon abandoned. At different periods in the serenteenth century serious complaints were urged against one or other of the Regulated Companies. They continued to exist, in most cases, through the eighteenth century, but in the later stage their real importance was less. Either they dropped their monopolistic practices or came to acquiesce in the existence of a good deal of technically illicit competition from interlopers. Among the Joint Stock enterprises the East Indian and the Hudson's Bay did great constructive 
work. The African Company, on the other hand, was consistently a failure. It may be conjectured that the conditions of the African trade were exceptionally unfarourable to the Company form. There was not sufficient cohesion among the native tribes to resist the raiding intertoper, and the company could, in consequence, do little for the indiridual which he could not do better for himself. In 1750 the joint stock company was wound up, and all existing interests consolidated into a regulated company. Most of the capital expenditure was, howerer, defrayed by the nation.

Of the collision between English traters and weaker races during this period perthats the less said the hetter. It is, however, obligatory to remember that the momopoly of supplying slaves to the Spanish colonies was obtained by the military and diplomatic power of the comntry amiol general approval. The part which has been played by Arab slavers in the last century of African history was played in the eighteenth century by Englishmen; nor is there reason to believe that the horrors of the "micldle passage " were inferior to those of the "caravan." The methods of exploitation adopted by the Last Indian and Hudson's Bay Company were of a more subtle kind, and rerleemed to some extent by military heroism and pioneering grit. The beginning of better things in India dated from the reforms of Clive. But the real turning point Wai the administration of Warren Hastings. There is a strange tragerly in the fact that the latter, who was the first great example of the better type of English proconsuls, slould have gone down to popular inagination as an unscrupulous tyrant. 


\section{CH.MPTER III}

FINANCE AND TAXATION

Is all matters which fall within the somewhat vague limits of the term finance, the century which followed the Restoration marks a turning point. Taxation roted by Parliament came to be the normal method of meeting ordinary expenditure which harl hitherto been met chiefly from the herechitary revenues of the Crown. It ceased, moreover, to be aderuate for the cost of war, even with the help of such loans in anticipation of revenue as had become increasingly common from the thirteenth century onwards. Hence the definitive adoption in the eighternth century of the srstem of funded debt. The monetary problem was revolutionised by the growing substitution of credit instruments for coins, and in a less degree by the use of machinery at the mint. The system of slort credit gradually permeated business in the larger onmereial centres. In a few cases it was found desirable to go farther even than this. For the inadequacy of individual capital and the instability of credit a remedy was discovered in the Joint Stock principle. In each particular we discover a more complex machinery which on the one hand economises enormously the force of the nation, whether for conomic or political effort, and on the other when used unintelligently generates wholesale disaster. The statesane and the inductrive organiser are less dependent on the personal resources of themselves and their immediate friends. Organised institutions and markets develop, which will perform defined services on defined terms. The conditions and consequences of alternative schemes become more calculable. The foundations are laid for a science of finance. In the history of this transition the incidents of most importance are the success of the House of Commons in the Constitutional struggle, and the establishment of the Bank of England.

It is clear that by the end of the sixteenth century the hereditary revenues of the Crown were no longer adequate to the ordinary expenditure of the country. This was due partly to the fall in the purchasing power of money, partly to the extravagance of Henry VIII, partly to the growing need for a more elaborate peace 
establishment. Even Elizabeth, though she pushed thrift up to if not beyond the limits of foolhardiness, had ntilised the patent system and condoned piracy to make ends meet. She had also regulated her foreign policy on lines of econony, which were ultimately irreconcilable with the growing national desire for commercial expansion. In the seventeenth century the rise of prices continued until 1660. The Stuarts were extravagant. Cromwell's military despotism was inevitably expensive. The need for naval expenditure in times of peace was more and more recognised. An increase of expenditure was unavoidable. The constitutional struggle decided by whom that expenditure should be controlled. The success of Parliament resulted in the development of a comparatively sound funancial method at a much earlier date than in most Continental comntries. Apart from technical points of immense importance-e.g., that taxation should be roted annually, which necessitated an annual budget--the fact that the finances of each administration were criticised in debate made for good management. It is true that the opposition occasionally defeated a raluable proposal, as when IIalpole was compelled to withdraw part of his reforms. But the financial record of England, after the Rovolution, compares favourably with the average of absolute monarchies.

The first sixty years of the seventeenth century were a period of fiscal experiments. Those of James I and Charles I bore little fruit, since they becane part of the constitutional dispute and were thrown aside by the successful party. Between 1640 and 1660 on the other hand. one form of taxation-the excise-was introduced, which was retained after the Restoration. It has, however, been pointed out earlier that l'ym's excise and some of the Stuart patents had points in common. All parties instinctively perceived that the economic development of the nation had reached a point at which internal taxation of commodities was both feasible and produtive. Exrise duties were steadily developed and became one of the chief heads of revenue. Considerable elasticity was shown by the customs, also, as the trate of the country gradually increased.

The principle that national expenditnie should be controlled in detail by the House of commons was not established until the Revolution. Cecil hat attempted, in 1610, to secure a permanent revenue in lien of the profits of the court of wards and 
liveries and the prerogative of purveyance. His plan. however, assumed that the revenue would be assigned permanently to the Crown. and that its expenditure would be as independent of parliamentary control as was that of the old ordinary revenue. The negotiations over, "the great contract " came to nothing. and the doubtfully legal expedients resorted to by the Crown, precipitated the Civil War. It is. however, clear that the reluctance of the Commons to find money was not due to a desire to guide expenditure: they objected to the policy of the Crown, and took this way of obstructing it: they had not. and the country generally had not, decided finally that ordinary expenditure should be subject to detailed control by Parliament. Hence, in the early years of the Restoration we find the Commons roting money to Charles II for his life, and estimating the total to be made up on the basis of the necessary expenditure of the Crown in ordinary times.

This minimum expenditure was estimated at $f 1,200,000$, of which

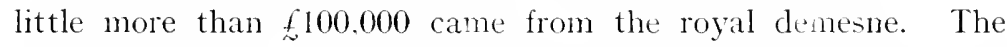
feudal dues were finally abandoned; but the excise duties granted in exchange for them were actually made hereditary in the Crown instead of being granted for the life of the King. It has often been pointed out that the burden of the feudal dues was shifted by this arrangement from the shoulders of certain families on to the general public, and especially the working classes, and if we consider the finance of the seventeenth century as a whole it appears that this tendency is its principal characteristic. It may be doubted, however, whether the determining factor in this development was the political supremacy of landed and moneyed men; for the Crown had equally under Elizabeth and the first two Stuarts attempted to increase its revenue by taxes on articles of general consumption. Two forces co-operated with the distribution of political power to produce this trend in the fiscal system. First the ease with which revenue could be raised by this method. Direct property taxes had always been difficult to collect, and the breakdown of the close relations between local authorities and the central government would make them more so. Secondly, in all men's ideas taxes on property were associated with extraordinary expenditure, whereas in the form of customs duties taxation of commodities had long been a source of regular revenue. Hence it was natural for Parliament when called upon to increase the ordinary revenue to prefer 
taxation of commodities. It should also be noted that the hearth tax, which was imposed at the same time, acted as a rough income tax with a minimum limit, cottages being exempt. Whatever the explanation, the growing disregard of equity in taxation as compared with productivity is very noticeable. Far more important than the substitution of excise for feudal dues, which after all was a question of only some $f 100,000$ a year, was the cumulative tendency to throw the burden of war upon the masses which resulted from the combination of commodity taxation with loans for extraordinary expenditure. It was, of course, much easier to raise money by loan than by a special tax on property; the misrhief was that the interest upon the loans became part of the ordinary expenditure of the country, and was ratsed by taxation of commodities instead of by taxation of property. It must, however, be remembered that the poor rate, which fell on property, rose pretty stearlily through the serenteenth and eighteenth centuries.

In 1688 the principal taxes were as follows:-

\begin{tabular}{|c|c|c|c|c|}
\hline \multicolumn{2}{|c|}{ Hearth Money } & $\ldots$ & $\ldots$ & $\ldots \quad+200,000$ \\
\hline Customs & . . & . . & . . & f992,000 \\
\hline Fixcise & . & . . & . & 6620,000 \\
\hline
\end{tabular}

These figmes may be compared with the following statement for 1755 :

\begin{tabular}{|c|c|c|c|c|}
\hline Lant Tax & & & .. & $81,000,000$ \\
\hline Mindow I & $1 \mathrm{~T}$ & len & ons & 235,000 \\
\hline Customs & $\ldots$ & $\ldots$ & $f 1,780,000$ & \\
\hline Excise & . & . & $3,660,000$ & \\
\hline Stamps . & . & . & . & 137,000 \\
\hline
\end{tabular}

The land tax wats now annual, whereas during the Restoration period sums hat been raised ocasionally by the old subsidies, by sperial assesments, by poll taxes, and so on. On the other hand

1 Sie lowell, "Hfistory of Taxation," Vol. 11, pl. 34, 127. 
it will be seen that whilst the window tax, the tax on pensions, and the stamps together bring in $\$ 372,000$, as compared with $£ 200,000$, the yield of the Hearth money in 1688, Customs and Excise yield $f \mathbf{5 , 4 4 0 , 0 0 0}$ against $£ \mathbf{1 , 6 0 0 , 0 0 0}$. The revenue of $f 1,000,00)$ from land in 1755 compares unfarourably with the 19.000.000 raised by property taxes during the twelve years 1689 to 1700 . When war broke out, however, in 1756 the land tax was raised from $2 \mathrm{~s}$. to $4 \mathrm{~s}$. in the $f$, and brought in $f 2,000,000$.

The taxation of commodities already pressed hardly upon the very smallest incomes, for it must be remembered that in the absence of sanitation fermented liquor was almost necessary to health. Like the beer and spirit duties, most of these taxes fell with most severity on the lower middle class, artisans. and labourers.

As the nation was driven to taxation of commodities by the growing difficulty of collecting money in any other way, so it was driven to the expedient of a permanent debt, by the inadequacy of the old method of extraordinary taxation. The advantage of borrowing as compared with taxation is evident since it artificially. selects those who can from those who cannot dispense with part of their income without loss of efficiency or other undue strain. If one can assume that the taxation required for interest and sinking fund will be laid equitably, the only arguments which can be urged against borrowing are those which depend upon the encouragement to extraragance which results from its advantages. It is sufficiently clear that the eighteenth century disgraced itself by extravagant borrowing and the nineteenth by niggardly repayment, for though it is true that the gains from national expenditure are shared by future generations it is also plain that they depreciate very rapidly, and that the debt incurred in producing them ought to be speedily wiped out. Often, also, expenditure which has entailed borrowing leaves a country no stronger, or even weaker, to face subsequent dangers. The expenditure of England in the Crimean War is a case in point. It is therefore somewhat disquieting to remark that history minimises the hope that any successful attempt to clear off national debt will ever be made. In only one case throughout the history of the English debt has the addition made during one war been cleared off before the outbreak of the next. It had always been customary to appropriate specific taxes as security for advances made by moneyed men to the Government. It the 
Rerolution the sums required were so large that immediate repayment was unthinkable. The floating charges already amounted in 1791 to over $\$ 3,000,000$. In $1792+1,000,000$ was borrowed on the security of liquor duties, which were to provide a fund for the parment of life annuities to the lenders. Finally the $f 1,200,000$ lent by the Bank of England, in retum for its charter in 1794, constituted the first " funded debt," there being no provision for wiping off the capital obligation. In 1697 (Peace of Rrswick) the capital of the debt had reached $f 21,000,000$. in 1713 (L'trecht) $\$ 53,000,000$. By 1740 it had been reduced to $847,000,000$. In 1748 it was $7 / 8,000,000$, in $1756 \pm 72,000,000$, in 1763 (end of Seven Years' War) $\$ 122,000,000$ funded and $\$ 14,000,000$ floating. Conversions were effected in 1717,1727 . and 1749 . A sinking fund was established without much success in 1716 . The debt was very little watered during this period, and most of the stock was issued at par or at only a small discomt.

The early history of the debt is intimately associated with the foundation of the Bank of England, whose capital was, and still is, in great part lent to the govermment, and into whose hands the management of the debt eventually passed. Even the earky history of the bank, however, is not purely political. Its foundation marks an important stage in the economic development of the country. By the end of the sixteenth century the use of credit instruments to effect payments between listant places was firmly estahlished, and it appears that in international trade London was already becoming an important centre of these operations. Credit was frequently given by seller to purchaser, and the trade bills arising from such transactions were dealt in by moneyed men who bought them for inrestments, or with the object of transferring funds to agents at the places on which the were drawn. A market in bills was thus formed, and fluctuations in their prices, i.e. upward and downward movements of the exchanges. influenced the profits of exporting and importing, and in this way still further reduced the need for bullion shipments. The peculiar developments of the period in the field of private finance were the spread of deposit banking, and the promotion of Joint Stock enterprises, whose shares became the subject of speculative sale and purchase.

Lntil 1640 it seems to have been the rule alike for merchants and moneyed men to keep any minvested funds either on their 
own premises or at the Tower of London. From the frequency of monetary stringencies it is probable that the total of such surplus funds-beyond the safety limit of till money required by each individual - was normally very small: the 130,000 of bullion seized by Charles I from the Tower in 1640 was a special consignment on its way from Spain to Dunkirk. The action of the Crown at all events made men distrust the Tower as a place of safe deposit, at the very moment when, as a result of the Civil War, prudent men were presumably decreasing their commitments and investments. The strong rooms of the goldsmiths offered an alternative, and considerable sums were deposited with them for safe lieeping, both by merchants and by landowners. The goldsmiths, however, were already financiers, and it was natural for them to lend out part of these deposits, reserving only sufficient to meet probable calls. The profits earned were so considerable that they soon began to attract deposits by the offer of interest, and by 1680 they had built up a considerable banking business. Before the dissolution of the Long Parliament, they had already begun to circulate notes payable to the bearer on demand. Under the Restoration they advanced considerable sums to the Crown in anticipation of the taxes. The stoppage of payments by the exchequer in 1672 showed that the whole business of the country was bound up with the system. The goldsmiths claimed that their ruin would involve the ruin of 10,000 clepositors.

As early as 1651 the first tract in favour of a chartered bank had been published. In the reign of Charles II projects multiplied. There were many who felt that the goldsmiths having stumbled upon a profitable line of business were exploiting it in their own interest, and that it might be possible to secure by chartered management either some specific object of general advantage or greater stimulus for the economic development of the country, or both. These demands were in fact the expression of the still prevailing beliefs that regulated was preferable to unregulated enterprise, and that exceptional gains should in some way be secured for the public, and not left to individuals. The Bank which ultimately emerged was very far from satisfying these feelings completely, in spite of its considerable services to the State. We shall find in the opposition which it met at several crises in the first hundred years of its existence, the echoes of complaints which were urged 
before 1694 against the goldsmiths. These last undoubtedly turned their opportmities to account with a minimum of regard either for the security of their depositors or the usury law. Failures, as the result of over investment of deposits, were frequent, and whilst the maximm rate of interest allowed by law had been reduced to six per cent. in 1652, they probably extracted as much as fifteen per cent. from the Crown, and indefinitely higher rates from private individuals. To this it should be added that the combination of deposit banking with their older trade of money changing gave them exceptional opportunities of manipulating the comage to their own adrantage. It was supposed that they not only sorted out for export the heavier pieces, and loaned ont and paid their note and deposit liabilities with light pieces exclusively, but even resorted to "clipping " and "sweating." It is a matter of some difficulty to sort out the wheat from the chaff in these allegations, and to account for the defects of the system. It seems clear in the first place that the goldsmiths seldom, if ever, controlled a capital large enough to do miscellaneous banking safely. If it was necessary for them to offer depositors six per cent. at a time when this was the maxinum allowed by law, their credit cannot have been super-excellent. Yet the mere fact that they had to pay six per cent. to their depositors must have compelled them to undertake business at rates of interest which clenoted yet greater risks, or to squeeze inflividuals whom they knew to be in difficulties. It might reasonably be held that a chartered institution would both command greater confidence and be less likely to deseend to usury or fraut on the coinage. The average rate of interest for short loans when they are mate in accordance with a sound routine, and when the number of transartions which insure one another is sufficiently large, onght to be exeerlingly moderate. It can, however, be driven up very considerably where these conditions are not fulfilled. Arrocates of banks under the Restoration, although they claimed that their selemes, if realised, wonld eause a recluction in the rate of interest, dicl not reason exactly in this way. They considered that the bank would increase the supply of money and that its price would fall in consecpuence meaning by price the rate of interest. liut although their argument was defective. they had a clear pereeption of the kernel of the matter. They saw that a bank would command more confidence than a goldsmith, 
as a result of its larger operations and more conservative management. Its better credit would enable it to borrow on easier tems, and this again would permit of its lending at lower rates. l'etty. in his tract "Quantulumcumque" (1682), ontlined that analysis of the real economy of credit which formed the backbone of Ricardo's work on currency. He held that the erection of a bank would " almost double the effect of our coined money," and that if this resulted in a ghut of coin "we may melt down the heariest, and turn it into the splendour of Plate, in ressels or Utensils of Gold and Silver ; or send it out, as a commodity, where the same is wanting or desired ; or let it out at interest where interest is high.". 1 He had also perceived the connection between the interest obtainable for loans and the interest obtainable by other forms of investment, e.g., in land, houses, or job-horses. Hence he disliked limitations on freedom of export of money and the fixing of a maximum rate of interest by law. But it was long before these theorie's won the assent of the business world.

The Bank of England owed its charter less to a deliberate cognisance by the Government of the services which such an institution conkl perform to the business world than to pressing neressities of State. We have seen that the Revolution entailed considerable loans. By 1694 the traditional methods of finance were exhansted. fi,200,000 were urgently needed to balance the year's expenditure, and a scheme suggested by Paterson was carriedout without much modification. The "Governor and Company of the lank of England" were chartered to collect and lend to the Govermment $£ 1,200,000$. The Gorernment engaged to pay $f_{100,000}$ per annum until 1705 , when they were to be at liberty to discharge the debt. So far the affair was merely a national loan. The creditor corporation, in adclition to the interest, "was authorised to issue notes, to deal in bullion and commercial bills, and to make advances on merchandise." 2 It issued notes to the amount of $f 1,200,000$; it discomnter trade bills, received deposits, and lent money on security.

Its success, and the services which it rendered to the Government, was so great that it was able to secure from time to time renewal and extension of its privileges. In 1697 the foundation of its monopoly of corporate banking in England was laid, and this

1 Sir W. Petty, Works, II, $4+6$.

2 Conant, "Nudern Banks of Issue," 82. 
was strengthened in 1709. In 1751 it took over the management of the National Debt.

The objections which were urged against the Bank in the first seventy rears of its existence were not generally speaking very intelligent. They were rooted either in the jealousy of the goldsmiths or in the suspicion that the Bank derived from its privileges a benefit disproportionate to its services to the State. It is easy to see now that the existence of the Bank gave a false turn to banking development generally in this country, but for lack of experience this could hardly be known at the time. The monopoly of Joint Stock Banking, as Scotch experience showed, was not necessary to preserve the stability of the Bank. Its effect was rather to prevent the private bankers from being swallowed up in amalgamations. In other words it stopped the transition from private to Joint Stock banking, whose commencement was the principal economic gain from the establishment of the Bank. It is probable, though less certain, that the extension of banking facilities in the provinces was also delayed. It was at one time proposed that the Bank should establish branches in the country towns, and if it had been faced by the competition of other corporations it is probable that this would have been done. The provinces offered little scope to the private banker until the Industrial Revolution. In 1750 there were very few "bankers' shops " outside London. It is, however, probable that a powerful corporation would have been able to circulate its notes from branches, as was actually done in Scotland. As the case lay, the rise of banking during the Industrial Revolution was organised by private firms with disastrous results.

The establishment of the Bank of England was followed by the first considerable investment mania which the country had witnessed-a prorluct no doubt in part of the increased credit facilities which the bank placed at the disposal of the public. Throngh 1694, 1695, and part of 1696 a number of new enterprises, sound and insomul, were set on foot: existing lunsinesses were sold to promoters who over-capitalised them; there were lotteries and schemes for banks, and the cruclest of mining frands. "The projectors . . pretend a mighty vein of gold, silver, or copper, to have been discovered in a piece of sround of the ir knowledge: then they agree with the ford or patentee for a small yearly rent, or a part reserved 
to him, to grant them a lease for twenty-one years to dig that ground; which they immediately fall to, and give out it is a very rich mine. Next, they settle a company, divide it usually into four hundred shares, and pretend to carry on the work for the benefit of the proprietors; who at the beginning purchase shares at a low rate, viz. ten or twenty shillings, etc. Then, all on a surden, they rum up the shares to three pounds, five pounds, ten pounds, and fifteen pounds per share." 1 The reaction came in 1696, accentuated by the recoinage. A run on the Bank was organised by hostile parties, which was defeated by justifiable if unsavo ry expedients. The Government relieved the strain by the issue of a temporary paper currency-exchequer $f_{\mathrm{N}} 10$ bonds, hearing a high rate of interest until their redemption.

From this time onwards hardly a decade passed without the credit cycle of boom and depression, althongh the intensity of the phenomenon varied enormously from the South Sea Bubble in 1720 to the hardly discernible boom in the woollen industiy in the early forties and early fifties. Already in 1698 the mass of stock jobbing had become so great that it moved from the Royal Exchange and found a separate home in Change Alley. It was here that the mania of 1720 centred. A further outburst of speculation in the early 'thirties produced the repressive Act of 1734, " to prevent the infamous Practice of Stock Jobbing." Already in 1719 the Bubble Act $^{2}$ had prohibited the formation of conipanies with transferable shares, unless chartered by the Crown or by Parliament. Repressive legislation was powerless to prevent Stock Jobbing, since this could be carried on in privacy. The rough handling of intruders, which is still de rigle on the English Stock Exchange probably goes back to a once real danger of informers. The professional operators remained unorganised until 1760, though they all frequented the coffee houses in Change Alley, and had their offices there. In 1760 the more reputable among them drew together into the London Stock Exchange Association, whose members met at one particular house, ${ }^{3}$ just as did the associated insurance brokers at Lloyd's. But though speculation could not be

1 Anderson: “Origin of Commerce," II, 615.

2 Promoted by the South Sea Company out of jealousy towards subsidiary enterprises, it nitimately ruined its promuters.

${ }^{3}$ The Stock Exchange Coffee House, in Threadncedle Street. They also transacted some business in the Rotunda, at the Bank of England.

I5- (I+98) 
prevented by legislation, it was able to check materially the growtl of the company form of organisation, for a company cannot avoid publicity. It is true that most of the unclartered companies which were formed between the Revolution and 1720, were bubbles, but the whole history of the sixteenth and seventeenth centuries points to the conclusion that capitalism was feeling its way towards the use of company organisation in many kinds of production. The enterprises of adventurers in the reign of Elizabeth, and later, are already more than mere partnerships, and it is plain that behind the scandalous frauds of the Bubble there existed a solid economic movement towards larger organisation. As things were, this morement was checked in its beginnings. On the eve of the Industrial Revolution the technique of corporate enterprise outside banking and insurance was in its infancy ${ }^{1}$ - so much so that Adam Smith, under-estimating the adverse effects of restrictive legislation, concluded that the Joint Stock concern could hardly compete with private enterprise unless it was specially privileged.

The history of currency during this period centres in the re-coinage of 1695 . The causes which necessitated this measure were in all respects analogous to those which have been explained in earlier sections. A great variety of coins was struck during the seventeenth century, especially whilst the Civil War was in progress, and there was still in circulation a certain number of pre-Elizabethan pieces which had escaped her melting pot. The result was both a great diversity in the metallic content of coins nominally the same, and an average debasement of fifty per cent., as shown by experiments with samples at the Exchequer and in the chief provincial towns. The mill and the press liad been introduced at the Mint in 1663, but the coins disappeared as soon as they were issued. The matter was of the utmost importance after the Revolution. It was necessary for the Government to transfer considerable sums abroad, but the exchanges moved against the country. The large jssues of notes by the Bank of England no doubt contributed to this result by kereping up prices at home, " restricting the export of commolities. and making the despatch of bullion necessary. conseglentiy the market price of the precions metals diverged

1 The comelitions in India and Canala were so peculias that the experience of the East India and lludson's Bay C mupanies was of little use.

2 It will berememlered that $1694-6$ were years of boum and over-speculation. 
more and more from the Mint price. The market price of gold hat fluctuated between $f t$ and $f 41$ s. $6 \mathrm{~d}$. per ounce during 1694 . In January, 1695, it was only fit 0s. 6d. By June 14th it hat risen to $\$ 5$ 9s. The par of exchange on Amsterdam was $37_{17}^{1}$. By Jannary 18 th, 1695 , the rate had fallen already to $32 \cdot 7$. It continued to fall throughout the year until November, during which month it fluctuated between 28 and $27 \cdot 5$.

In November Parliament met and addressed itself to a reform of the currency. Lowndes, the Secretary of the Treasury, wished to raise the nominal value of the coins issued by twenty-five per cent., so that the Crown should be current at $75 \mathrm{~d}$. instead of 60 (d. This plan hamonised with the tratitional practice of reducing the metallic content of the coins whilst retaining their old denominations ; and the proposed alteration was exceedingly moderate in view of the actual deterioration of the coins as noted above. A proposal to raise the denomination had secured the approval of a committee in the Commons when Locke intervened. His argument, if not altogether satisfactory, was effective politically. It conkd be shown that the loss to the Govermment by a re-coinage at the old standard would be more than made good by the increased value of revenue, both in England and still more abroad. Further, that all creditors and landowners would be better off if their interest and rents were paid in heary instead of in light money. His riew carried the day: the light and debased coins were called in and full weight ones issued in their place. The whole operation cost the government between two and three millions. Although Mints were set at work in five provincial towns as well as in London, the recoinage, as has been seen, occasioned a serious monetary stringency. It was not finally complete until 1699. Part of the scheme was to readjust the legal ratio between the gold and silver coins. Gold had been rated too ligh in silver, with the result that the heavier silver pieces were melted down for export, gold being coined in their place. The reduction in the silver value of the guinea was not sufficient to check this practice, and it was still further reduced in 1717 to 21s., but even so there remained a small profit on exporting new silver coins. There is no doubt that these difficulties prepared men's minds for the adoption of the gold standard. One effect of the re-coinage was to stimulate the use of credit substitutes for money. As has been seen, the stringency in 1696 had been mitigated by the 
issue of Exchequer Notes, which bore interest and were received in parment of the King's taxes. They were issued for sums as small as 5 and 10 . but in general it is not till the close of the eighteenth century that we find credit instruments used for the adjustment of small parments. Lntil 1759 the Bank of England issued no notes of less than 20 . 


\section{BOOK IV}

THE INDUSTRIAL, REVOLUTION AND

$$
\begin{gathered}
\text { ITS CONSEQUENCES } \\
1,60-1900
\end{gathered}
$$





\section{CHAPTER I}

\section{GENERAL SURVEY}

THE term "Industrial Revolution" was applied by Toynbee to the Economic History of England between 1760 and 1830. Neither beginning nor end can be marked as definitely as with some political revolutions, but economic change during these years was sufficiently sudden and dramatic to justify use of the term. The old order had not really been stationary, but change, as has been seen, had been, for a century and a half, abnormally slow. It now acquired suddenly unprecedented momentum. Again, whilst it is true that this momentum has gathered rather than lost force since 1830 , the close of the Rerolution may be dated from that year. Nen had begun to realise the extent and direction of the change which had come upon England, and were shaping ideas and policies conformable to the new conditions of life.

The Industrial Revolution was the work of a mere handful of men. Some ten or twelve individuals revolutionised, or created, each of a number of great industries. What these men had in common was a power of surveying economic problems in a cool and rational spirit, of cutting themselves loose from the control of what had been done, and the way in which it had been done. Viewed in this light the Industrial Revolution falls into its proper place in relation to the main stream of eighteenth century history. It denotes the triumph of rationalism in the economic sphere. It need hardly be added that a peculiar combination of circumstances was required to enable a handful of men to produce such enormous results in a particular comtry, and at a particular time. Events had been working for centuries to make possible the Industrial Revolution in England, as they had also been working for centuries to make possible a political Revolution in France.

In general, the feasibility of large scale production was the one thing which permitted a ferw individuals to alter the economic life of the nation. It gave to the cotton or iron king a greater direct authority. He controlled, as the result of it, a larger 
field. Indirectly the scale of his success adrertised his methods proportionately, and led to their more rapid spread among secondary imitators. The rush to open up new industries, the phenomenally rapid growth of manufacturing and mining districts, were prophetic of later developments in the Lnited States or on Australian gold-fields.

Hence, in seeking the causes of the Industrial Revolution, we must ask what were the conditions which made possible the sudden growth of large scale production at this particular period. These causes have been presented in outine already. (1) The decay of State regulation of industry, which left to the individual a freer hand in utilising capital and labour and marketing his products. (2) The growth, in all departments of thought, of rationalism. In the economic sphere progress in production had gradually ceased to depend primarily upon the imitative faculty, guided by the survival of the fittest among chance variations: it came now to depend primarily upon imagination, experiment, and reason. (3) Political events. The empire and prestige of England had opened markets which promised to absorb any imaginable increase in the output of certain commodities. At the same time the security of the country from invasion, and the maintenance of order within its borders, had permitted the investment habit to develop until men were ready to lay out money on capital which could easily be destroyed, which yielded its returns slowly, and which could not he remored or secreted. These conditions had been slowly ripening since the close of the seventeenth century, and meantime an initial process of experiment had been gone through leading up to the needful technique of large scale industry. The ground was thus prepared for the rise of the great staple industries of the nineteenth century-mining, metallurgy, textiles, ceramics. Ifen had been familiarised in London with the possibilities of banking credit and joint stock enterprise. The first steps har been taken in the improsement of communications.

The achierements of the Industrial Rerolution, between 1760 and 1830 , may be summarised briefly as follows. The two considerable influstries which existed in 1760 , namely agriculture and cloth, had changed much both in technique and structure, whilst several other industries, notally coal, cotton, iron, and ceramics, had risen to the first rank. Whilst mannfactures of the domestic type had continued to expand, the influence of capitalism over them 
had increased, and whole branches of important industries were now carried on in large scale establishments with expensive plant. Throughout the country, and between England and the rest of the world, exchange had grown suiftly, as particular centres and districts served wider and wider markets. Correspondingly the most important manufacturing industries had been localised in districts especially well provided with clay, ore, coal, or waterpower, whilst in agriculture also had occurred a marked increase of local specialisation. These changes harl partly caused, partly been caused by a general extension of banking facilities throughout the country, and the construction of two systems of communication-roads and canals. The increase in productive power, combined with the breaking up of traditional arrangements, and in some degree also defects in Poor Law administration, had brought about rapid growth of population. The population of England and Wales is supposed to have reached $5,000,000$ in 1600 , and $6,500,000$ in 1750 . At the census of 1831 it was $13,800,000$. Its centre of gravity had shifted from the South and Eastern Counties to the Midlands, Lancashire, and the West Riding, and a very considerable part of the increased numbers was packed densely in towns. It was clear already that if the population continued to increase, England would not be able to provide the whole of the necessary food supply. She was alrearly dependent on foreign countries for cotton and other important raw materials. Finally the changes which had occurred had shifted the conditions on which economic and social regulation depend. Much of the traditional system had been already destroyed, and the beginnings of new methods could be seen.

These changes had been accompanied by, and in part at least responsible for. an incalculable quantity of human misery and degradation. The evil which ineritably attends any considerable change in the technique of production had been accentuated by irregularity in the course of change. During the whole seventy years there had been a rapid succession of enormous fluctuations. The difficulties of the period had been increased by faulty regulation of banking, and by the uncertainties of war. In spite of much general benevolence there was a growing distrust of interference by the State in economic matters, a distrust which, however indefensible in theory, was partly justified by the practical defects 
of existing political machinery. The rapid growth of towns was bringing with it erils which had long resisted remedy in London, but which now first began to affect a large proportion of the total population. Employment in mines and factories, together with the use of machinery, gave birth to problems for whose understanding and treatment no background of experience existed. Finally the accidental coincidence in time between the Industrial Revolution and the most serious strain of war to which the nation has ever been subjected, intensified all other evils. It drew men's attention into other chamnels: it made them ready to acquiesce in any evils which conld be represented as incidental to increased productive power: it increased the pressure of taxation upon men whose earnings were already close to, if not below, the level necessary to efficiency.

If we glance now for a moment at the history of the succeeding period 1830-1900, we notice first a continuance of the economic reorganisation, whose earlier stages have been traced above. There is growth of large scale production together with distribution of the product from local centres over wider and wider areas; growth of transport and credit facilities; increased dependence upon other parts of the world for food and raw materials; confinued growth of the population in manufacturing districts, and especially in commercial and manufacturing towns. On the other hand the problems of social organisation which were generated, or thrown into relief, by the Industrial Revolution have absorbed more and more attention. Starting with a grave distrust of the power of the State to interfere with advantage, the nation gradually reconstructs its political machinery, and swings round to something like confielence in its power to formulate and carry out deliberate schemes for good. To a period which may be called a period of laisser faire -roughly 1830-1870--succeds a period which has been called collectivist. These terms must not be pressed too hard. The output of constructive legislation in the earlier period was considerable, whilst the sense in which "we are all socialists now" is somewhat elusive of definition. They provide, however, a scheme for the history of the Victorian epoch ; the main business of any such history is to explain the canses of the anthoritative part played l,y individualist theory before 1870 , and its rapid loss of puwer between that date and the conchsion of the century. As 
a preliminary to this discussion we must go back to the period of revolution between 1760 and 1830 , and watch the conflict between old ideas and new facts, whilst over all, obscuring men's judgment. hung the cloud of war.

We have traced, in an earlier chapter, the gradual development in the seventeenth and eighteenth centuries of an educated opinion distrustful of State intervention in economic matters. This opinion was the natural product in the field of sociology of the individualist movement in European thought. The natural right of the individual had been opposed in religion to the divine right of the Church, in politics to the divine right of the King. The natural right of the individual to act in business according to what he judged to be his own interest was an inevitable extension of these idleas. To such an extension the conditions of industry in England during the seventeenth and eighteenth centuries were particularly favourable. The absence of revolutionary transitions made the intervention of the State less necessary, and the State itself contained so much corruption and inefficiency that the seed of distrust ripened fast. On the eve of the Industrial Revolntion the majority of the governing class were not as yet hostile to intervention, whilst the organisers of industry rather despised than disliked it. There remained, however, little of that unquestioning assumption of its benefits which had been characteristic of the Elizabethan period. In fact men's minds were moving rapidly towards a point at which the "simple and easy system of natural liberty," alreadly preached by a minority, would win general acceptance. By a peculiar irony this minority produced a preacher of exceptional persuasiveness, at the moment when the fundamental conditions of the problem were about to change. "The Wealth of Nations," which was published in 1776 , had been composed in the previous decade. It deals with, and is based upon, study of the conditions which had prevailed with little alteration for a century and a half before the Industrial Revolution. That it has also a universal quality is not denied, but it gave deficier faulty guidance in regard to a number of problems which, comparatively unimportant in 1750 , had risen to the first rank in 1800. What is true of Adam Smith is true of Bentham. His work also was really most relevant to the state of society before the Industrial Revolution. The length of life which enabled him to establish his authority on the young men 
of 1800-1830 was so far a misfortune in that they viewed the complex problems of the new industry from the standpoint of more simple conditions.

The influence of Bentham does not at present concern us. It was not of much importance till after 1830. But Adam Smith, by his attention to the problems of finance, foreign trade, and colonial administration acquired an immediate fame, the first fruits of which were seen in the fiscal reforms effected by Pitt before the outbreak of the French War. Thus, when the problems of regulating the relations between the new race of industrial organisers and their employees began to become acute, those who had an interest in non-intervention could point to an admitted authority, whilst on the other band there remained only a somewhat hukewarm sympathy with the policy of regulation, since most of the legislators had gained what experience they had at a time when regulation was relatively unimportant. Of culpable indifference to the sufferings of the masses there is in this period no exceptional sign. The Poor Law system inaugurated by the Speenhamland resolutions in 1795 , and approved by the Government, was, at any rate, well intentioned, and so far as mere money goes, generous. But it was inevitable that where the interest of emplovers in freedom came into collision with the desire of workers for regulation, the more articulate party, armed with the systematic arguments of "The Wealth of Nations," should be victorious.

Our conclusions, so far, may be summed up as follows:-The English nation was called to deal with many problems of exceptional complexity at a time when defective machinery of internal government combined with the culmination of the individualist movement in European thought to make men suspicions of regulation. At the same time it was subjeet first to the strain of continued war, and later to a weight of taxation (much of it ill-devised) which remained over from the war. The driving force of individualism had enabled the nation to endure the strain to the admiration of all Europe. It is hardly surprising that some years elapsed before serious attempts were marle to grapple with the new problems and that economy of govermmental effort continned to be preached after such attempts had begun. It is equally intelligible that the nation should gratually recover its balance from the accidental bias towards non-intervention, and that 
constructive ideals should increase their hold on men's minds between 1830 and 1900 .

The recovery was delayed by the disciplined body of thought which had grown between 1780 and 1830, about the work of Adam Smith and Bentham. The doctrine that individuals knew their interest better than the State could know it for them agreed well with the experience of those members of the community who had been borne upwarts to fortune and political power by the wave of the Industrial Revolution. Further, the two chief extant examples of the effects of Government intervention in economic matters, viz., the Poor Law system, and the tariff, fumished the individwalists with an extensive assortment of practicable weapons. Men who felt that the State ought to do much could point to nothing that it actually did well. The maintenance of law and order is essential to complex economic organisation: but the kind of law and order provided by the State in 1830 might in itself be used as an argument for reducing State action to the minimum. Hence although the years $1830-1870$ actually witnessed important beginnings of constructive legislation, the atmosphere of the time was destructive of privilege and intervention, whilst departures from this spirit were classed as exceptions. ${ }^{1}$ Other tendencies of thought were, it is true, well represented. A tradition of paternal humanitarianism continued among the Tories: from 1816 onwards Robert Owen was setting ideas afloat which lie at the root of our recent legislative history ; German thought was beginning to reach England; the poets to a man were against the economists. For a moment, in the early thirties, it looked as though these several movements might draw together into a counterpoise of individualism. But the early socialists and factory reformers lacked the intellectual discipline which, during the past fifty years, had moulded a compact and apparently consistent individualist creed. Moreover, their potential following was chiefly amongst the wageearning class, and this class had not yet obtained the vote or developed the gift of political strategy. Hence indiridudist utilitarianism became the dominant creed, and even laid a distinctive mark on trade unionist policy after 1850 . So great

${ }^{1}$ Notice particularly the curious attempt to save the face of individualist theory by restricting factory legislation nominally to women and children, although it was well understood that it would in practice affect adult males also. 
was its prestige that for the moment it made tributary to itself inquiries which should have maintained their independence. Political economy was incorporated: economists were utilitarians, and utilitarians economists. I raid on history was made by Buckle. Herbert Spercer undertook to show that applications of erolutionary theory to society bore out the prescience of Bentham. By 1860, however, opposition to the dominant creed was gathering fast. Carlyle, Ruskin, and Dickens thundered against it, whilst John Stuart Mill-a more insidious enemy-was destroying from within its terse simplicity.

Still more important was the gradually accumulating experience of beneficial interrention, whether by the State or by roluntary associations. with the course of competition. When in the early 'eighties socialism again became a force in English politics, the situation was the converse of that which had existed in 1830 . At the earlier date, as has been seen, individualism enjoyed the credit of haring provided the sinews of war, whilst collectivism was discredited by the Poor Law and the tariff; at the later date the beneficial results of the liberal movement had become so much a part of the texture of national life that men were forgetting already to what they were due; on the other hand, whilst many crying evils were palpably present, the effects of such intervention as the State had undertaken during the past fifty years appeared satisfactory ; trade unionism had established the beneficial results of collective bargaining: the achierements of co-operation on the one hand, the crils of private monopoly on the other, were suggesting the possible adrantage of extended municipal enterprise.

It has been observed earlier that a superficial resemblance exists between the modern and Elizabethan ages. Ilen have drifted steadily during the past thirty vears towards an almost Elizabethan confidence in the beneficial results of State control and intervention. But the resemblance, so far as it exists, is one of temperament and method: it does not appear in aims and ideals. Perhaps it is premature to attempt any definition of the aims of modem lingland. It may, howerer, be permissible to bring ont a fow points of ontrast between our own and the Elizabethan Iye. It the end of the sixteenth century the State was still conceived as necessarily consisting of a series of classes whose 
standard of income and expenditure and whose responsibilities were properly distinct. This riew is, of course, still held by many, perhaps by the majority of both rich and poor, but it finds, comparatively speaking, very little echo in public speech and writing. The thought which most expresses itself is sceptical as to the validity and utility of class distinctions: at most it acquiesces in them as an inevitable evil. Almost all the socio-economic legislation of the past seventy years has aimed at minimising their extent. There is, on the other hand, little of that egalitarian sentiment which made the Elizabethan careless of differences in the efficiency and deserts of individuals in a given class. The tendency of trade unions to restrict the earning power of the most efficient workers is widely misapprehended and exaggerated. Similarly the common objection to socialists that they aim at suppressing individual distinctions displays as total a misconception of the aims of that important group of English Socialists, which has borrowed one half of its ideas from eighteenth century indiridualism. Their quarrel with society might be stated in terms almost identical with those which Bentham would have used. They conceive that in its broater aspect it distributes wealth without due regard to individual desert. and that the unearned fortune of a privileged minority involves misery for a disinherited majority. Bentham and his followers shared this view. The distinction between the two schools is primarily one of means and not of ends. The former believed that the intervention of the State almost inevitably promoted and strengthened privilege: the latter believes that the action of unregulated competition has a like result : they have in common the desire to maximise opportunities for individual development, to make individual fortune as dependent as possible upon desert, as independent as possible of chance, birth, and privilege. Hence, whilst the aim of Elizabethan statesmanship was in one at least of its aspects to consolidate class distinctions, the aim of modern statesmanship, so far as it is not mere drift, is to obliterate them. The difference comes out strikingly in regard to educational policy. It is, of course, ridiculous to pretend that national education is a product of the nineteenth century. The Elizabethan apprenticeship system and grammar schools were just as truly a national provision for education. The difference may be expressed thus. To the Elizabethan it seemed clear that the earlier an individual chose a definite line of 
work, and the closer he stuck to it the better upon the whole would be the constitution of society. It was assumed that children would normally follow their parents - the heir of Royalty to the throne, the son of Burleigh to the serrice of the Crown, the son of the ploughman to the plough. The modern theory of education is based on the contrary assumption that a maximum of inter-class fluidity is desirable, and the modem educational system is intended to facilitate the rise from all classes of the most gifted inctividuals.

It is partly a cause, partly a result, of this difference between the Elizabethan and the modern ideal, that whereas at the end of the sixteenth century policies were lesigned and applied from above, the development of modern policy is largely a movement from below. Even extreme Socialists in England owe more of their practical expedients to the experiments which have been made by poverty in trade unionism and co-operation than to professional statesmen or thinkers; and whereas Elizabethan statesmen relied for the execution of their policies on quasi-autocratic action by nominated justices of the peace, in modem England the efficiency of State intervention depends largely upon representative gorernment and voluntary association. The vitality of the principle of association is eridence of the existence of a minority of rigorous individuals throughout the mass of societr. If the test of class vigour is its capacity to throw up organising and administrative ability, the English working classes in the nineteenth century can challenge comparison with the English landed aristocracy in the eighteenth. This peruliarity is the prime distinction between modern England and the Roman Empire. The desire for "bread and circuses" is of course as widespread among English wage-earners as was the desire for port and pugilism among the eighteenth century aristocracy. The capacity to initiate policit's, and to grasp the political power which is needeel to carry them out, is listinctive of the former as it was distinctire of the latter; and this capacity guarantees a certain social stability, for it presupposes a leaven of solid character. It cannot, of course, guarantee harmonious development of society, lut it is its essential pre-requisite. Social progress, so far as it depends upon willed artions at all, is geremed by the extent of foresight and of willingness to sacrilice the present to the future. There is much that is shert-siglated, and much that is selfish in the demands of all "interests" in modern lingland - in this respect we 
compare less favourably than is often supposed with earlier ages--but the modern historian may clain, without undue optimism or conceit for his contemporaries, that the opportunities for good which increased power of production offer, have not been entirely neglected. We have, at least, interest in and discussion of socio-conomic problems on a scale unprecedented in history. 


\section{CHAPTER II}

THE GREAT INVENTIONS

THE superficial facts of the Industrial Revolution have been often described. They may be resumed briefly under two heads. First, there are the changes in the technique of production, the use of new mechanical devices and scientific processes either to attain ends which had previously been attained more expensively and clumsily, or to produce what before could not be produced at all. It will be convenient to sub-divide our description of them by considering in turn the industries chiefly affected-viz., agriculture, textiles, coal, iron and steel, and mechanical and civil engineering. These sub-divisions, however, must be transgressed occasionally for the reactions between the several industries were of enormous importance, and the effect of certain inventions, especially those in mining, metallurgy, and engineering, extended over the whole field of industry.

Secondly, attention must be directed to structural alterations in the economy of the country. In the industries whose technique had been revolutionised, the old organisation was no longer suitable. Important shifts in the distribution of economic functions took place; the most obrious being the tendency towards enlargement in the productive unit, which resulted from the increased importance of fixed capital. Structural change, howerer, was by no means confined to the industries whose technique had undergone extensive alteration. The increased facilities for transport affected almost every class of producers by extending at once the range of the market which they could supply, and of the competition which it was necessary for them to face. The result was a quite general increase in production for exchange and narrowing of the number of distinct tasks to which an individual could profitably aply his labour. Further, this increas of exchange led to the growth of intermediary classes of agents and trarkers - particularly important being the rise of banking, the development of produce markets, and of retail trate.

\section{A.-Technique.}

1. Agriculture. In agriculture, between 1760 and 1830 , th chief 
morement was an elaboration and generalisation of principles already practised by the most progressive farmers in the first half of the eighteenth century. The principles may be grouped conseniently under two heads, the conception that the productive power of a given acreage could be increased by skilful rotation of crops and careful manuring, and the deliberate selection of breeding stock and seed with a view to preserving the most profitable, and weeding out the wasteful varieties.

The practice of Tull and Townshend could not extend rapidly in the first half of the eighteenth century. The survival of openfield farming kept much of the land of the country beyond the scope of free individual management. Apart from this there was no great need for an increase in the national supply of food. The population increased slowly and the prices of agricultural products ruled low. In the next fifty years a great rise in prices took place : enclosure of the common fields became rapid; and between 1760 and 1830 great progress was made in spreading knowledge and educating landowners and farmers ; three events of central importance stand out from the rest, riz., the individual endeavours of Arthur Young, the example of the Holkham estates, and the activity of the Board of Agriculture.

Arthur Young was born in 1741. In 1767 he commenced a series of tours, in the course of which he examined the agricultural conditions of England, Ireland, and France. In "A Six Weeks' Tour through the Southern Counties of England and Wales " (1768), and "A Six Konths' Tour through the North of England" (1770), he ably describes the existing state of agriculture, with ruming comments of criticism and suggestion, and more detailed study of the methods employed on the most advanced estates. In addition to these longer works he produced, for many years, a series of pamphlets, and acted as Secretary of the Board of Agriculture from its establishment in 1793 until he became blind, in 1810 . His propaganda was largely directed towards those changes of land tenure which were necessary if the land of the country was to be brought under the control of intelligent men who had capital at their disposal. But improvements in technique, the introduction of the best methods and implements were his ultimate aim. His interest in enclosures was derived from the belief that they were an indispensable condition of this development. Coke of Holkham 
was the leader among a number of great landowners who distinguished themselves by stimulating agricultural improvements upon their estates. He led the way in growing wheat successfully on light soils, continuing and improving the principles adopted by Townshend half-a-century before. It is stated that the rental of his estate rose from $£ 2,200$ in 1776 to $£ 20,000$ in 1816. This result was principally due to a recreation of the land by manuring and a careful nursing of its properties by skilful rotation. His influence was not confined to his own tenants, whom he partly edncated and partly compelled to follow the lead of his home farm, but spread widely through the country. From 1778 annual meetings were held at Holkham, lasting a week, which were attended by improvers from all parts of the country, and which fulfilled the purpose of exhibitions. Coke, as has been said, was only one of a number of landlords wio distinguished themselves in this way. The movement was centralised by the establishment of the Board of Agriculture, in 1793, already referred to. Its "Amnals of Agriculture," edited by Arthur Young, were a great addition to the technical literature of farming; information was collected in a more systematic manner than had previously been attempted, and statistics were gradually provided of stock and crop acreage, and of the prices of important agricultural products.

In "The Origin of Species," Darwin could fall back in some measure upon the experience of practical breeders, but it does not seem that there was much conscious attempt to develop the most vahuable types of animal and regetable life before the eightaenth century. There had in fact been an unfortunate selection of the worse rather than the better individuals. Through the centuries when much of the stock was shanghtered and salted year by year for lack of winter keep, the tendency was ineritably to pick ont those calves which hat matured most rapidly and which promised the best eating. There was some dehiberate mating, especially in the rase of animals used in war or sport, with the object of leeping up the best level obtained; but the development of new breerls, even in the case of horses, rlogs, and sporting or pet birch, seems to have been mainly unconscious. The first important figure in the new movement is that of Bakewell (1725-1795). He thought ont the kind of sheep and cattle which would pay best, anrl set to work to produce them by breeding from individuals 
which had some of the qualities of which he was in search. His greatest success was with sleep. He replaced lean. long-legged, large-boned animals with the "New Leicester," which gave the farmer a maximum of saleable meat. In cattle his success was les: marked, though still considerable. His actual achievements were unimportant as compared with his influence. Breeds of sleep were developed in accordance with his principles to suit the local peculiarities of other districts. The New Leicesters were best in the plains. The Southdowns were improved to suit the hills, and the Cheviots for the mountains. His imitators, moreover, had more success with cattle.

Conscious development of regetable types progressed more slowly. Although the Dutch gardeners had early tried to produce new varieties of the tulip, it is only of quite recent years that considerable attention has been devoted to improving wheat and developing its rarieties in reference to local peculiarities of soil or climate. In the eighteenth century, however, Coke called attention to the importance of good seed for hay crops, which, up to that time had contained a large proportion of indifferent, or even deleterious growths. He employed children, who had previously received simple botany lessons, to bring in supplies of the seed of the best grasses, and thereby increased the percentage of valuable feed in his crop.

II.-Textiles. The technical improvements in the textile group can be presented most easily by discussing first the succession of inventions which created the cotton industry, and subsequently working out the way in which machinery gradually spread to the linen, wool, and silk inclustries.

Cotton. The adoption of Kay's flying shuttle (invented 1733) which doubled the output of the weaver, intensified a difficulty which had already been somewhat felt, viz., the discrepancy between the pace of weaving and the supply of yarn. It was difficult to adjust the one to the other, because spimning was only occasionally the occupation of the adult man. Wonen and children did the bulk of the work, and an increase in their numbers was likely to increase the number of weavers. In the cotton industry the incentive to invention was increased by the inability of English spinners to produce a yarn of sufficient strength to be used as warp. Accordingly, after much unsuccessful experiment, 
we find almost simultaneously invented the spinning-jenny of Hargreares (1765), and the water-frame of Arkwright (1767-70). The former enabled one worker to operate a number of spindles simultaneously. It could be, and was, applied domestically, and it produced thread of the same quality as the domestic spinners had previously produced-i.e., suitable only for weft. The latter was worked by power (originally water-power, whence the name); it necessitated the factory or mill; it produced a thread which could be used as warp. In 1775 Arkwright took out a second patent which enabled him to co-ordinate the processes of carding, drawing. roving. and spinning. He was able to send raw cotton into his factory and bring out thread. almost the whole work being done by machinery. But the thread which he produced was coarse, and was not suitable for the imitation of the fine Indian muslins. In 1779 Crompton invented the mule. which combined elements of the jenny and the water-frame, and produced thread which was at once fine and strong. The result of these three inventions was the definitive conquest of the spinning industry by the factory. Arkwright had used water power from 1770; in mule-spinning, hand or horse porier was employed until the end of the century when it pasted rapidly to steam.

The relative positions of spinning and weaving were now reversed : although labour poured into cotton-wearing the new hands could hardly keep pace with the increasing supplies of yarn, and wages rose rapidly. This position did not last long. The power loom was invented by Cartwright in 1785. and as early as 1789 steam had been applied. In attempt to establish a large factory at Manchester was defeated by the hand-loom weavers in 1791, who bumt it to the ground, but in spite of opposition the new machinery made sufficiently rapid progress to destroy the brief prosperity of the lianl-foom. In the course of the next fifteen years it was gradually improsed. Radcliffe and Johnson worked out a series of mechanical derices which passed the varn automatically thromgh preparatory processes until it reached the loom and emerged as doth. Horrocks introluced looms made entirely of iron, and consepuently at once less chmsy and less liable to clamage or wear than the earlier patterns. Nevertheless, in $\mathbf{1 8 1 5}$ there were only some 3,000 power looms in the country, and as late as 1825 , when the number had grown to 30,000 , there still 
seemed to be a future for hand-fooms which still numbered some 250,000. Nine years later the power-looms numbered 100,000 , and the condition of the hand-loom weavers was desperate. Meantime spinning machinery had been much improved: in common with all other machinery it profited by the general substitution of iron for wood as material, and by the transition from water to steam power. Technical inventions were common in the subsidiary branches of the cotton industry as well as in spinning and wearing. We may notice chemical bleaching, which was firmly established by 1800 , the substitution of cylinder for block printing some fifteen years earlier, and Heathcoat's lace-making machine patents in 1808-9.

Other Textile Industries. A patent, adapting the principles of the water-frame to flax-spinning, was taken out in 1787, and at once began to be used by a few firms. It was not, howerer, a commercial success until 1793, when improvements were introduced. In 1809 the first patent for hackling was taken out. I'ntil the end of the war all linen wearing was done on hand-looms in the workers' homes. About that time some of the spinning manufacturers added wearing sheds, and at a still later date power-looms were introduced. The silk industry seems to have been less immediately affected than any other branch of textiles by the new inventions. We have seen above that thrown silk was produced by power-driven machinery in a factory as early as 1719; in other departments of the industry the domestic system long continued predominant. The Jacquard loom, however, which immensely facilitated the weaving of complicated patterns, was patented in England in 1820 and soon introduced at Coventry. In the woollen industry machinery was introduced very gradually. Certain processes antecedent to spinning were first taken over, the domestic workers in the West Riding, who received wool and returned it woven into cloth to dealers, being not averse from relinquishing some of the heavier work. Carding machinery had been patented by Lewis Paul in 1748 , and seems to have been general by the end of the century. The spinning jenny was used in Yorkshire as early as 1773, and was adopted with a minimum of opposition. It enabled the domestic weaver to secure from the labour of his wife and chifdren a more nearly adequate supply of yarn. In other parts of the country there was considerable delay. In the South-west it was 
not used till 1790. By 1800 the factory system was spreading in Yorkshire; the preparatory processes were taken over by powerdriven machinery, whilst before power was applied to spimning or weaving certain of the merchant capitalists in Leeds began to group jennies, mules, and fy-shuttle looms on their own premises; in the later years of the war the combined pressure of machinery and the continental system had brought the workers to the state of desperation described in "Shirley." The cloth industries of the SonthIlest and the Eastern connties showed small capacity to adapt the new methods. They were cut off from the stimuluts of direct contact with the cotton industry, and less well provided with water-power and (ual.

III.-Coal, Iron, and Sted. The most important improvement in mining was the general introluction of steam pumping engines towards the end of the century, as a result of Watt's improvements on Nervermen's fure engine. The older plan of draining mines by cutting adits, as the works were deepened, was becoming impracticable, even in the hilly districts, in consequence of the great depth of the shafts. Progress was also made in raising the cual or ore, steam haulage being gradually substituted for physical labour. In 1820 Goorge Stephenson used mechanical traction in the workings, but progress here was much slower, partly in consequence of the cheapness of chikl labour, until the Mining Lets of the forties, partly on account of the chmsiness of chains or hempen ropes, the only means available until the perfecting of wire ropes after 1862 . Cast iron rails were laid down first at Coalbrookdale in 1767. Wooken props logan to be substituted for the older method of learing colnmus of unworker coal in 1795, the systom being greatly impored in 1810. In 1815 the Davy lamp was invented and first used in the next year. Abont 1820 increased attention was paid to ventilation

This inpurement in mining was. of course, the result of the inceredser demand for both fuel and ore, which resulted from the expansion of metaliurgy and its subsidiary inchustries. By 1766 the production of irom with coke fuel hat been so far perfected as to admit of a rapid development of thenew industry of iron castings. The incentions of the lonbys were supplenenterl by imporements in the primitive bellows. In 1760 sincatom constructed blowing cylinders for kochuck at the carron Iren Works. They were 
driven by water-power and gave a powerful blast, though imperfectly regulated. This difficulty was finally solved by the steam engine. Neantime the puddling and rolling processes, patented by Cort in 1783-4, had opened the way for the production of malleable iron with coal, and still earlier Huntsman, at Sheffield, had invented a process for casting steel. The great iron-masters employed water and subsequently steam power wherever opportunity offered, as was, indeed, necessary in view of the weight and mass of the material they manipulated. One of the earliest of the applications made by Watt of his steam engine was the construction of a "tilt" hammer, which would strike 300 blows a minute with a head of $7 !$ cwt. and a two-foot stroke. The perfecting of the production of cast iron made iron for many purposes a more easily manipulated material than wood or stone; it was also, of course, cheaper than copper, tin, bronze, brass, and peiwter. Hence an enormous industry rapidly developed. The first iron bridge was opened in 1779 , the materials having been cast at Coalbrookdale. Iron boats were used on canals in 1790 . Iron became the chief material of ordnance. The new water supply of Paris was carried in English iron pipes.

The use of iron for structural purposes was rapidly extended by the Civil Engineers, and in 1820 it was employed for sea-going ships. Iron rails had been laid down in collieries in 1767, and with the expansion of public railways, which goes back to 1801 , their use became more and more important. The great expansion of the rail industry belongs, however, to the period of steam locomotion, and falls outside the limit of 1830 .

IV.-Mechanical Engineering. Perhaps the most important results were those obtained in mechanical engineering, for when the problems of producing iron and steel cheaply, and working it with accuracy, began to be solved, the potential efficiency and durability of machinery were immensely increased. Complex machinery could hardly ever be a commercial success so long as the only materials available were the softer and more expensive metals, wood, and clumsily hand wrought iron. Even when manual dexterity, acquired by life-long specialisation, had produced a machine whose parts fitted one another with sufficient accuracy, the wooden parts were liable to warp, crack, expand or contract under strain and variation of temperature, and both wood and soft metal wore out rapidly. Moreover, manual dexterity 
working on these materials could not produce easily interchangable parts. The prime cost of producing a machine was practically repeated for every duplicate or fellow turned out. If a screw were damaged it was easier to bore a new worm-hole and cut a screw to fit it than to cut a new screw to the old hole.

A most important impetus to the search for more accurate working was given by the development of the steam engine. The necessary physics were worked ont by Watt within a very short time of his attention being drawn to the question when repairing a model of Newcomen's fire engine in 1763. Nor did it take him long to invent his devices for preventing waste of heat and to realise his theories in a tolerable working model. By 1767 he had advanced so far that Roebuck was convinced of the certainty of ultimate success. The two became partners, an arrangement which placed at Watt's disposal both money and the technical equipment of the Carron works. But in spite of the European reputation of the carronade. the iron cylinders bored for Watt by the same machinery were nearly half-an-inch ont. whilst an y softer material wore rapidly. In 1773, in consequence of pecuniary difficulties, Roebuck transferred his partnership rights to Boulton. Watt went to Birmingham, and in 1776 constructed an engine for Wilkinson which worked successfully. His success was due partly to the specialised dexterity of Boulton's metal workers. partly to the invention by Wilkinson of better boring machinery. It was not, however, till some time later that iron and steel were adopted for all the wearing parts of machinery. Correspondence between Boulton and Watt proves that the advantage of doing so was recognised by them in 1781, and in 1786 the engines and machinery constructed for the new Albion Mills, near Blackfriars Briclge, were constructed entirely of cast or wrought iron. It was not until 20 years later that it began to be used generally for textile machinery; but between 1803 and 1830 it rapidly becane the predominating material for all kinds of machinery. The use of iron as material led naturally to the making of machinery by machinery a movement which had an important outcome in the system of interchangeable parts. The greater difficulty of working iron by hand was by itself sufficient to promote this development so soon as the steam engine had provided a source of power which could readily be increased at will and adapted to different purposes. A further impetus was given 
by Bramah's invention of the hydraulic press in 1795. Amongst his workmen was Maudslar, known as re-inventor in England of the slide rest for holding lathe tools. and remarkable for his influence in the direction of accurate workmanship. He trained a rising school of engineers. anongst them Murray. Whitworth. Roberts, Clement, Nasmyth, and Inuir, who carried on the work in various directions.

From the moment of Watt's definitive success, in 1776. the perfecting of the steam engine was pushed forward rapidly. progress at the Soho works being principally due to Watt himself. and his assistant IIurdock. The improvements fall into two classes, on the one hand inereased economies and smoother working of the machine itself, on the other adaptations of the original pumping type to perform any desired motion. Application of steam to navigation was worked out by Symington before 1788. Its first commercial success in Great Britain was achieved by Bell's "Comet." which began to ply regularly on the Clyde in 1813. A marine engine, constructed at the Soho works, hat earlier driven Fulton's "Clermont," on the Hudson, and Fulton had derived his idea from the "Charlotte Dundas," built by Srmington in 1801, which navigated the Forth and Clyde Canal succesfully. but which the proprietors, through prejudice. refused to use. The idea of steam locomotives came gradually to the front between 1800 and 1830. Trevithick exhibited a road locomotive in 1803, and a tramway locomotive in the next year. Stephenson constructed his first engine in 1814, and in 1823 was appointed engineer to the Stockton and Darlington Railway. In 1829 his "Rocket " attained a speed of twenty-nine miles an hour. and in 1830 the Liverpool and Ianchester Railway was opened.

T.-Cieil Engineering. The achievements of civil engineering between 1760 and 1830 lie at the very heart of the Industrial Revolution. Improved facilities for communication marle possible large scale production and localised concentration of industry. In each of the main branches of their activity, the building of roads and the building of canals, the English and Scotch engineers developed a practically original technique which owed very little to continental experience; their work is of further importance as leading up to and making possible the Railroad construction in the middle of the nineteenth century. 
Roads. Before the eighteenth century no systematic construction had been done since the Roman evacuation of Britain. With all the wear of fourteen centuries the Roman roads were the best in the country. Generally speaking the highway was a longitudinal rut, interrupted by boulders and pits, the whole of what, for lack of a better word, must be called the "surface" being sunk by continuous wear well below the adjacent fields, and, in the low lying country, chronically muddy and occasionally flooded. The Romans had attained directness at the cost of neglecting gradients: in roads of more recent date little attention had been paid to either point. The movement for improving the roads dates back to the reign of Charles II, the first Turmpike Act having been passed in 1663. Little was done for eighty years more, but the difficulty of mobilising to meet the Pretender's raid, in 1745, impressed the government with the need of progress. During the next twenty years an enormous amount of work was done in all parts of the country, and contemporaries remarked on the great cheapening of transport which resulted. The movement once begun continued with increasing force. Between 1760 and 1774 more than 450 Acts for the maintenance or construction of roads were passed. It is at this point that the first of the great road engineers of the Industrial Revolution comes upon the scene. Netcalf distinguished himself in the difficult country on either side of the Pennines, both by picking out routes with due attention to gradient and direction, and by inventing a plan for carrying the road securely across soft bottoms. Slightly later in date was the work of Telford, whose name is especially connected with North Wales and Scotland. He obtained a fair surface, but at a disproportionate expenditure of labour. The secret of a cheap and firm surface was discovered by Nlacarlam in 1815, who substituted for unbroken flints, which wore easily into ruts, a packing of angular granite fragments which consolidates into a natural concrete that requires the pick to disturl, it.

Cancls. Writing, in 1847, Porter could state that no spot in England, sonth of 1 nurham, was more than fiftern miles distant from navigable water, and that over the greater part of the comntry the naximum distance was only ten miles. In our own day, if we observed such facts we should not comment on them. It has become diffecult to realise the part played by inland navigation in 
the economic history of the serenty years previous to the railway movement. As early as 1677 Yarranton had pointed out the desirability of improving the natural waterways and connecting them with canals, but very little was accomplished 11p to the construction of the Bridgewater Canal, which was opened for traffic in 1761. The Duke of Bridgewater conceived the idea of connecting coal mines on his estate at Worsley, with the growing Manchester demand. and at first intended to use the Worsley Brook. From this he was dissuaded by his employee Brindley, who constructed instead a canal. With the possible exception of Metcalf, the blind surveyor, Brindley is the greatest example of the practical genius of the eighteenth century. At the summit of his reputation he could hardly read and write: he had not received and did not give himself any discoverable scientific training; yet as regards both conception and execution his work was epoch-making in the fullest sense. He had observed that almost any expenditure is worth while if it dispenses with a considerable fall and a variable volume of water. Hence his dislike both of locks and of river canals. He preferred a canal to the Worsley Brook enlarged, because it would give him a straight cut filled with water, whose depth and current could be controlled accurately. He began his canal by tunnelling underground to the coal workings, and ended it on an aqueduct: he tunnelled through obstacles, and carried bridges across streams in order to avoid locking. There is, of course, room for expert discussion of the question whether he exactly hit the best relation between increased expense of construction and diminished cost of transport and maintenance. The astounding thing is that he exaggerated, if at all, on the side of eventual simplicity secured by complicated engineering trimmphs over natural obstacles. His powers of detailed execution were equally remarkable. He invented a method of building watertight embankments, and of underpinning them to prevent subsidence in the marshes. He trained workmen-the first professional "navvies" (navigators) who were seen in England. He adopted from roadmaking the plan of utilising each constructed section to bring up materials or carry away the excavation of the next. For this purpose he devised special boats, and fitted up floating forges and carpenters' shops. He made good use of the steam engine of the day when floods threatened his works. 
His fir:t success was so complete that from that date onwards canals were constructed as quickly as Acts could be got through Parliament, and engineers and labour provided. Brindley worked himself to death between 1760 and 1772, but he had time to complete or commence other important works, and to pian out the main lines of the canal system which connected the new manufacturing districts of Lancashire and Yorkshire with Bristol. Birmingham, and London. Minor systems rapidly developed round the great industrial centres.

\section{B.-Economic Structure.}

I.-Agriculture. It was noticed that Arthur Young deroted a great part of his propagandist work to recommending changes in the system of land tenure, and it was then briefly stated that such changes were an indispensable pre-requisite of general progress in technique. It least a third of the cultivated land of the country was still being farmed on the open-field system in 1760 . Where this was the case improvement was difficult for the co-owners, and impossible for the individnal. His scattered strips of arable must be devoted to the same crops, and be worked, or lie fallow at the same seasons as those of his neighbours. His cattle and sheep, mixed with the village herds on the common pastures, could have little other food than that afforded by the natural unimproved grass lands. The new technique then was unattainable, and all the secular evils of the system remained. He wasted time in passing from one piece of land to another. His crops were spoiled by the weeds of his more careless neighbours, and his cattle infected from their diseased stock. Eren in the enclosed districts the situation was capable of improvement. The keases were, in most cases, of short duration-six months or a year-and if there existed no tendency to rack-rent there was a very general distrust among the tenants of sinking capital in the land. As the eighteenth century wore to its close, the lines of feasible reconstruction grallually hecame clear. From the seventies onwards it was plain that the food supply wonld soon become totally inadequate mless change were made. Apart from the danger of starvation in time of war no adequate ontside sonrce of supply presented itself. It was, therefore, evidently necessary to increase home production, whilst the tendency to a rise in prices increased the profits and removed the difficulties of transition. From the first, two principal points were evident to the reformers. 
(1) The land system must be changed so as to admit of land being worked by up-to-date methods; (2) no mere change in the land system would effect the desired result unless in some way educational stimulus could be applied to the actual farmers. Hence the two great watchwords of the agrarian revolution-enclosure and langleases. Enclosure was evidently necessary. Apart from technical difficulties the psychology of the mass of co-owning farmers made it idle to think of development along co-operative lines. The leasehold system seemed preferable to proprietary working, because whilst it left more free capital in the hand of the farmer it exposed him to the stimulus of competition from the knowledge that if he did not work his land well, it was the landlord's interest to take another tenant. But the leases must be long. The short lease in the absence of legal protection to the tenant might be worse than no lease at all.

In the last decade of the eighteenth century the Board of Agriculture calculated that there were still more than 6,000,000 acres of waste land in England out of a total of over 22,000,000 in Great Britain. There was thus room for considerable extension of corngrowing by taking in hitherto uncultivated land as well as by enclosing, and so turning to better account the open fields. The existence of such large tracts of uncultivated waste as those noted by Arthur Young in his Northern Tour must be borne in mind when the statistics of the enclosure movement are considered. It is difficult to determine how far that movement represented a net addition to the crop acreage, and how far it merely facilitated a better use of land which had been tilled for centuries. The general course of the movement may be tracked by the number of Enclosure Acts passed in each decade. From 1720 to 1760 the number increases slowly - 33 in the years $1720-30,35$ from $1730-40$, 38 from 1740-50, 156 from 1750-60. The movement, properly speaking, begins in the next decade. In the years 1760-70, 424 Acts were passed, and in 1770-80, 642. In 1780-90 the number falls to 287, but rises again to 506 between 1790 and 1800, and 906 between 1800 and 1810. From this time the movement declines. It was 771 from $1810-20$, and 186 from 182 ) to 1830 .

This movement had two principal effects on the structure of agricultural industry. It led to the substitution of large tenant farms for small tenancies, and small copy and freeholds. It 
also, in many cases, reduced agricultural labourers to complete dependence on their wages and on charity.

The open-field system was the stronghold of the small holding. for it prevented the introduction of those agricultural improvements which paid best when they were taken up on a considerable scale by intelligent tenant farmers who invested capital with the assistance of progressive proprietors. Contemporaries noted that in districts which had long been enclosed, large farms were the rule, the smaller holdings being massed in districts where the open-field system had been retained. Apart from the economic advantage of applying the new technique on a large scale, other forces were at work, which drove in the same direction. The political importance of landed property led men, who made fortunes by trade or manufacturing, to buy estates, and such men were more likely to be eager for technical improvement than the older families. The expenses of enclosing were considerable. Apart from the cost of fencing the land assigned to him, each tenant had to pay a share of the excessive legal fees which the complication of the land law exacted. The small copyholder or free tenant, therefore, often found it to his interest to sell when his land was enclosed, to take up a tenancy, and to use the money obtained as working capital. His alternative was to mortgage his land very heavily and find himself without the capital necessary for effective working. These are the fundamental conditions underlying the movement, but in addition, especially in its early years, many cases occurred in which social and other pressure of an inequitable character was brought to bear on the small holder to compel him to sell his rights. We learn from Arthur Young that in the decade 1760-70 it was easy for unscrupulous magnates to throw an unfair share of the legal expenses upon the smaller holders, or at least by making the total cost unnecessarily high to compel them to sell. They could also be harassed by litigation. Finally the social and political prestige of the great landlord put them in many ways at his mercy.

The disappearance of the yeomanry thus made steady progress after 1760. By the end of the century Arthur Young reports their certain extinction. The series of agricultural crises between 1815 and 1830 completed the work. Almost all of those who had mortgaged their land or placed other charges upon it (and they were the 
majority) were compelled to sell by bankruptcy or its imminence. The tenant system of the nineteenth century was firmly established. Considerable proprietors let their land in large farms to tenants. The proprietors undertook permanent improvements: the tenants supplied circulating capital. The normal lease on well-managed estates was sufficiently long to encourage the tenant to work the land well, and by its provisions and clauses a complicated division of control of agricultural enterprise between landlord and tenant was achieved. The system, it will be seen, was admirably suited to force from the land the greatest possible quantity of a few staple products, especially cereals. What it lacked was elasticity, and this defect did not become important until late in the nineteentlu century.

The effects of these changes on the position of the wage-earners were complicated by the coincident transference to manufacturing towns of some of the most important by-industries. In particular the decay of domestic spinning, which until late in the century was carried on by the wives and daughters of agricultural wageearners in almost every county, was a serious detriment to them, and it is at least possible that the enclosure movement, taken by itself, increased the demand for their labour, and actually mitigated other evils. Certainly it promoted a more intensive working of the land, and though some machinery was introduced, progress here was small as compared with the increase in work to be done. On the other hand the enclosures cut the labourer off from some important sources of income. Where common pasture existed the labourers had usually been privileged to feed a cow or geese, and though the stock was miserably poor, it reduced the pressure on the labourer of bad harvests and irregular employment, and provided milk for his children which, though often no doubt tuberculous, was probably in general more wholesome than any food he fras likely to buy. This privilege, however, was in most cases merely by custom, and could not be protected by the law courts, and therefore, when enclosures were made it was only exceptionally that the labourer received compensation. Furthermore, it should be noted that although the payment of a small sum of money might satisfy equity as between man and man, it was far from doing so as between the descendants of the parties. The money disappeared soon enough, and the next generation of 17-( 1498$)$ 
labourers were no better off than if none had been paid. Hence the demand made by the humaner advocates of progress, that where common pastures were enclosed. enough land should be laid to each cottage to allow the labourer to keep a cow. This demand was seldom complied with, and was always liable to be upset by subsequent change. The position of the agricultural tabourer was too dependent for him to make any stand, eren if im ninety-nine cases out of a hundred he had not been willing enough to sacrifice the interests of his successors for a sum of money which he could spend on himself. Nor was the case in farour of allotments so overwhelming but that a fair-minded landowner could believe that he was acting in the best interests of the wage-earners by refusing to allow them the use of land. Although in general it was felt that the class suffered by losing the element of subsistence farming, which harl remained to them, it seemed evident, in particular cases, that land left in the hands of lazy and ignorant men made them more lazy and less ready to learn. The Poor Rates were sometimes higher in a parish where commons remained than in neighbouring parishes where they had been enclosed.

II.-Manufacture and Trunsport. Here the most important structural change, and that which, down to the present day, has proved most persistent, was the enlargement of the wit of production in certain branches of inchustry-in the textile industries "mills," in the metallurgical industry." works," in mining "pits," etc., etc. Some of these industries, as has been seen earlier, had been distinguished for several centuries by the abnormal size of the business units in them. Their size, however, had been large only in relation to the prevailing standard of the domestic industries. Arthur Young visited Walker's iron works at Rotherham in his tour in the north, and they evidently struck him as on the grand scale; ret the men employed, not only in the works but in the coal and irom mines adjacent to them, numbered only 500. In the next sixty years the larger concerns came to employ their thrusands of workmen, but even they were not large as compared with molem industry. Especially in the textile inchustries a shed, hardly laiger and with little more machinery in it than a fairsized London workshop would be called a factory at the beginning of the nineteenth century.

Nerertheless, enlargement of the unit is the first characteristic 
of the Industrial Revolution: we meet it in various degrees and forms in all directions. In the textile industries the nomal factory was large when contrasted with the domestic workshop, though it was small as compared with concerns in some other industries. From the outset the new iron industry experienced the centripetal forces which competition arakens when interest on fixed capital becomes a very important item in cost of production. We have noticed incidentally that Walker's concern at Rotherham had its own coal and iron mines-it was in fact, a "rertical " combination of what is sometimes supposed to be the modern type. A striking point in the development of the industry from 1760 onwards, is that growth occurs by the expansion of existing concerns nearly as much as by multiplications of plants. In the textile industry, on the other hand, the limits of profitable expansion for the individual business were soon reached. Arkwright had a controlling interest in a large number of spinning mills, but it clid not pay him to feclerate them into a single concern, and though examples of vertical combination, alike in the cotton and in the new woollen and worsted industries are not wanting, specialisation remained the rule as it remains down to owr own day. The industry which was most affected by this new principle was that of transport. Except in the case of foreign slipping and the national postal service carriage of goods and passengers had remained a business for the small man down to the middle of the eighteenth century. With the reconstruction and improvement of roads and the building of canals the beginning of the change can be seen. The armies of toll-men employed by the turnpike trusts have been disbanded, and many of the canals have been closed to traffic, or at least are now only used by the occasional private barge; but in the period we are considering we can trace on roads and canals the genesis of the modern railroad system. Passenger coach services were rapilly organised on the new roads, and some of the canal companies beside constructing and maintaining the new waterways, organised a goods and passenger service upon them. The increased clemant for coal and minerals led also to growth in mining undertakinss. Here, as in the case of metallurgical concerns, the initial capital required was so great that progress could more easily be made by expansions of existing concerns than by multiplication ; and where, as often happened, new concerns started they were bound 
to start on the grand scale with considerable capital. The coal industry supplies, at the end of the eighteenth century, an early instance of combination in the Newcastle "Vend.",- The loeal pits were organised into an association which anticipated the cartels of modern Germany. Sales were in the hands of a central office which distributed the orders in certain proportions to the federated concerns. On the other hand, we miss in the Industrial Revolution two of the most important kinds of large scale enterprise in the present day. The Bank of England's monopoly of joint stock banking kept the expansion of banking in the hands of innumerable private firms, atthough the contemporary development of the joint stock and branch system in Scotland shows that the conditions were already ripe for its adoption in England. The large retail store also finds noperer precedent between 1760 and 1830 ; it is a product of improved transport and of those urban agglomerations which transport and other causes were already bringing into existence.

The economy of larger units of production had thus been clearly seen before 1830 , and yet for the full development of the principle and the growth of joint stock enterprise we must wait until the Victorian era. The first effect of the Industrial Revolution in the cotton industry was an enormous extension of domestic weaving and even, for a time, domestic spinning along lines already laid down. Spinning, as we have seen, was soon taken over by the mills, tait weaving remained principally a domestic industry until about the end of our period. In the other textile industries the victory of the large unit was delayed even longer. The metallurgical industry remained what it had always been-a largescate industry: the same was true of mining. But the increased output of iron and steel led to a great derelopment of the domestic hardware industry in the Midlands, and even power was applied in some cases without much change in the industrial type. In Birmingham and Sheffield large blocks of workshops were erected where power was supplied by a single plant, each shop being rented to a domestic worker; and we find steam power distributed to Coventry silk weavers on the same plan. In transport we find only the commencement of the modern system, side l,y sicle with extension of the olet. 


\section{CHAPTER III}

GONERNMENT AND THE WAGE-EARNING CLASSES,

\section{$1760-1830$}

IT has sometimes been suggested that the Industrial Revolution transformed large numbers of previously indepentent producers into dependent wage-earners, and reduced the bargaining power of the existing wage-earning class. In both these views there is a large element of exaggeration and of misunderstanding of the change which actually took place. They cannot, however, be dismissed with a mere negation. For if one thing is certain about the first half of the nineteenth century, besides an enormous increase in productive power, it is the misery and want of the mass of Englishmen. It is clear, in the first place, that the mass of workers had been wage-earners, dependent for employment on middlemen for some centuries before the period in question. Adam Smith summed up the situation in his statement that throughout Europe there were twenty wage-earners for every one independent producer. ${ }^{1}$ or was the lot of the wage-eamer enviable. The truck system, the supply of bad materials, and similar devices flourished. The power of the Justices, backed by legislation, and the division of interest between competing labourers checked combination. The London tailoring industry was not affected structurally by the Industrial Revolution: there is no reason to suppose that its organisation altered appreciably between 1760 and 1815. A Any reader of the life of Francis Place, the journeyman breeches maker, can see that the "wageslave" is not a product of the Industrial Revolution. And this particular trade stood fairly high in the scale.

It may, hovever, be urged that though the mass of industrial labour was dependent upon capitalist emplosers before the Revolution, there was at least more chance for the inclividual to rise from the ranks of his fellows and employ them in his turn. l'usitive evidence on the subject is almost entirely lacking. Francis Place, it is true, succeeded in establishing a fashionable tailoring

1 " Wealth of Nations," Book I, Chap. VIII. 
business, but tailoring preserves, down to our own day, unusual opportunities for energy and skill to achieve independence. On the other hand we have no reason to suppose that the West of England clothiers, for instance, had often begun as wage-earners. It seems, on the contrary, more probable that wherever commercial capital was supreme it was recruited from the ranks of trade, and not from the mass of labour. However this may be, there is no doubt that the Industrial Revolution itself offered opportunities for the merest wage-earner to become a prosperous factory owner, and even our modern manufacturing system presents a ladder which, although too long to be climbed in one generation, is at least continuous. One suspects that industrial conditions in the eighteenth century had more resemblance to the present state of agriculture: it has often been remarked that owing to the lack of intermediate positions between those of agricultural labourers and farmers, it is difficult for the former to better themselves in many counties.

That exposition of the Industrial Revolution, which finds in it the origin of dependent wage-labour, rests upon imperfect knowledge of the conditions of industry before the revolution. Another plausible generalisation which lays stress on the wage-earner's loss of control over the instruments of production ignores the facts of our own day. Ownership of the tools or machinery of production is in itself a neutral force. An employer who serves out raw material, tools, or machinery to his employees may use them as the chamel through which his superior power will exploit them: but the things themselves do not give him the power, and an arrangement by which they supply their own implements will not save his employees if he has the power. Thus, in the sweated industries of modern towns we hear it sometimes asserted that exploitation is due to the fact that the employee rents his implements from the employer; whilst in other cases a grievance is made of the fact that oil or thread or what not have to be supplied by the operative. We shall see more clearly into the matter if we recollect that whilst ownership of her sewing machine will not save a woman from being sweated, ownership of factory and looms will not enable manufacturers to exploit a tracle mion. The crucial facts are the knowledge possessed by each party of the actual state of the labour and produce narkets, backed by power to combine. In a contest otherwise 
equal, the wage-earner has an advantage when his employer owns the plant, since he has less and his employer more to lose in the event of a stoppage; the loss of interest on capital is transferred from his shoulders to those of the entrepreneur. Finally, the doctrine that relations between employer and wage-earner are likely to be best when the number of employees is smallest and the social gulf between them and their employers is least, is emphatically negatived by modern experience. If any generalisation on the subject be permissible, it is that the larger unit has the advantage. Its directors are less likely to catch at temporary gains, and more likely to understand that exploitation is detrimental in the long run to their own interest, and their large sphere makes possible the economic prosecution of "welfare" work. Nor are these conclusions applicable merely to the growth of "economic chivalry" in our own day. From the rery beginning of the Industrial Revolution some of the large scale establishments were managed with considerable attention to the maintenance of the operatives' standard of life. It would almost be true to say that the employers whose brains made the revolntion, aroided its erils, and that the evils were the work of men of inferior calibre, who carried on and intensified the evil traditions of commercial capitalism.

It is hardly necessary to point ont that the factors of irregularity and heary taxation, which undonbtedly accentuated the evils of the period of transition, cannot be held to account for them entirely. That the price of wheat was driven from time to time by the risks of war, or by import duties, above $f_{5} \mathbf{a}$ quarter, and that even poorly paid employment could not always be got, might make intolerable what would otherwise have only been seriously bad. But in spite of the war the accumulated wealth and the productive power of the country increased rapidly, and we must seek some further explanation of the misery of the people.

The history of the period is really one of the chief examples in history of a primary social principle-viz., that virtue cannot coexist with anarchy. By this it is meant that certain controls, whether provided by law or by custom, are necessary, if life is to be better than a conflict of beasts. A period of anarchy can be created theoretically in two ways, by suddenly abolishing law and custom, or by suddenly creating new conditions to which law and custom cannot adapt themselves with sufficient rapidity. Of the former the 
condition of France in the early years of the Rerolution is a leading example; of the latter the condition of England at almost the same date. The duration of such a period is determined partly by the potency of the forces which cause the upheaval, partly by accidents in the course of opinion, and the emergence or non-emergence of indiriduals possessed of great organising ability. In France the accidental appearance of Napoleon put an end to anarchy at an early date; in England the coincidence of a philosophic movement opposed to intervention, together with a strange dearth of socio-political talent, prolonged it unduly.

Three important steps in regard to the regulation of employment were taken by Parliament between 1760 and 183 ). In 1813 the wages clauses of the statute of artificers were repealed; in 1814 its apprenticeship clauses were repealed; in 1799 and 1800 severe Acts were passed penalising combinations. In regard to the abaudonment of the Elizabethan labour code, the following points may be noted. Of its two chief provisions the assessment of reasonable wages by the Justices of the Peace, and the restriction of employment to those who had served an apprenticeship, and regulation of the number of apprentices, neither exactly fitted the clanged conditions of industry, though each contained, or implied, principles of lasting importance. The principle of assessment of wages by the Justices had been accepted at a time when the kind and degree of work required in each branch of industry was not susceptible of much modification-when, in fact, any attempt to raise or lower wages meant an attempt to alter the remuneration for a given kind of work. The development of machinery altered these conditions fundamentally. Henceforward the employer had to balance against one another the relative adrantages of coupling mere superintenclence with automatic machinery and dispensing entirely with machinery in favon of the highest degree of trained dexterity. Between these extreme positions there lay, of course, a large $131 m b$ of of possible intermediate expilibria. If we admit that wages oreght in any measure to depent on the quality of the labour supulied, it is evident that the reasonable wage in any industry would depenel upon the particular equilibrium between the use of mathinery and the ns of sperialised skill to which that indestry gravitated, and llut differently organised factories in the same industry might require different wage rates. This argument does 
not, of course, affect the proposition that a minimum wage for adult labour of all kinds, based upon the expenditure necessary for health and efficiency is desirable; nor does it in the least condemn the complicated lists of modern Lancashire which take account of the new variable introduced by machinery. It shows only that the Elizabethan system was unsuitable to the new conditions, and that more expert knowledge than that possessed by the Justices of the Peace was required in order to do even tolerable justice.

The system of restricting employment to men who had served an apprenticeship, and limitating the number of apprentices, was similarly inapplicable to the new conditions. It also had been framed at a time when the methods of an industry changed slowly, and when the proportion of the total labour power of the nation which each industry demanded, was not susceptible of rapid fluctuation. The Industrial Revolution brought to birtl the exact opposite of both these conditions. When the methods of production were suddenly revolutionised in an industry, it could no longer be claimed that those who had served an apprenticeship were likely to be more skilled in it than those who had not: and when rapid expansion of an industry became possible, restriction of apprenticeship produced as one of its results the evils of a labour trust; the men already in the trade could exploit the rest of the nation. Further, it could not be clamed in either case that the provisions of the Act were fully carried out. The practice of assessing wages had been almost universally abandoned, and though the apprenticeship system was vigorous in many industries, it was not so miversally. It had not been adopted in many new industries which had grown up since the sixteenth century, and when the conditions of the woollen weavers' industry were investigated in 1806, it appeared that even here "many of the best workmen had failed to serve a regular apprenticeship." " $\mathrm{Had}$ Parliament maintained and enforced the Act it would, under guise of conservatism, have inposed new conditions which were not altogether suitable to the existing state of industry.

Whatever the demerits of the Elizabethan system, the arguments of those who urged its abandonment showed an exaggerated confidence in the power of competition to adjust society satisfactorily.

\footnotetext{
'Cunningham, "Growth of English Industry and Comnerce," *** p. 658.
} 
The apprenticeship system was unsuitable to some industries, but in many there was evidence strongly farourable to it, and where this was not the case evils cxisted which called for some remedy. Parliament neither retained it where it appeared to work well, nor made any attempt to substitute some other system where it workerl badly. It must be achmittet, on the other hand, that the constructive substitute for wages assessments-viz., the extended out-relief-which Parliament commended, produced such evils in some districts as to justify the contention that a purely laisser faive policy wouk have been preferable. The at tempt to prevent the evils of industrial war by penalising combinations was equally unsatisfactory. Here again a purely laisser fuire policy would have been preferable. Throughout the eighteenth century combinations of "rage-earners had been, from time to time, prohibited in specified industries, but these prohibitions had been accompanied by legal detemination of the points at issue. By the end of the century Parliament hat realised that it was not capable of arbitrating skilfully on the complex developments of industry. This was true enough, but the deduction that no satisfactory arbitration was feasible was irrational. The further conclusion that organisations which aimed at a collective hargain should be penatised was wrong on all counts. It offended equally aganist the theory of paternalism, and the theory of individual liberty.

Evits of irregular employment, inadequate wages, and capitalist (pppression were, as has been remarked, of old standing in England. Their existence was fully admitted by Parliament, even when it abandoned the attempt to grapple directly with them. There were, howerer, a number of new evils- resulting from the changed conditions of industry - which only gradually won serions attention. One essential morelty in the sitnation was that a considerable proportion of the wage-arning masses passed their working lives in buildings or exarations whose cost entered into the market price of the commodities which they probluced. Agriculture, which hat always been at least part of the "rork of the mass of the pople, is carried on principally out of roors. The domestic worker either laboured in his own dwelling-house, the workshep accommodation l, ing here a kind of by-product of the existener of the bene or in a rough built sheel, often open to the weather on one sicle at least, as the village forge and the 
butcher's shop still are, and as other shops would be still but for the cheapness of plate-glass. Under these conditions the idea that lack of space or ventilation could affect the worker's health, was not likely to emerge, and even if the effect had been serious and demonstrable a remedy would have been almost impossible since the first incidence of the expense of better worlishop accommodation could not have been shifted on to a class distinct from the wage-earner.

The strain on physique of keeping up with machinery during a long day's work is another evif which could hardly be detected a priori. Much labour in the pre-machinery period had been sufficiently heary to deaden intelligence, and so badly distributed between the different limbs and muscles as to produce deformity. The tailor's legs and the potter's thumb are proverbial; and the callosities produced by ploughing are remarked in AngloSaxon literature. But machinery introduced nervous strains and monotonies which were previously unknown, and much time was required before appreciation of these new conditions could become general. This subject is of special interest in reference to child labour. Probably the most important social reaction of the Industrial Revolution was the attention drawn by it to the relative rights of parent and child. Exploitation of children-i.e. their employment for temporary gain with consequent damage or arrest to their developing faculties--was assuredly no new thing at the end of the eighteenth century. But the exploitation of previous ages had been chiefly harmful to mind and spirit, and not to physique; and the evil was therefore only perceptible to imaginative thinkers. Horeover, it had often been conducted by the actual parent. Child-labour had been sold less often to third persons for wages, keep, or training: and even in apprenticeship the masterworker often preserved for his few apprentices some of the elements of home life. The situation was greatly altered by the industrial revolution. Machine tending involves a physical strain, which is not entirety beyond the capacity of the child, as had been ploughing or digging, or the manipulation of a clumsy hand-loom. Instead of doing light work in the open air such as scaring birds, watcling flocks, or gleaning, or at worst light tasks of picking and sorting in the home workshop, the child was now required to keep pace with machinery driven by power for twelve or sixteen hours a day. 
Poor Law officials had long been wont, and encouraged, to apprentice pauper children, or to send them to sea. At the end of the eighteenth century the custom of sending them to factories, and especially to spiming mills, grew up. There is no reason to suppose that the lot of the pauper apprentice had ever been easy. Eren in our own day the Merchant Service is a rough nurse, and even the Royal Nary, at the end of the eighteenth century, was rotten with disciplinary tortures. Still, it is erident that the lot of factory children struck contemporaries as unprecedentedly bad, and there is reason to acquiesce in this conclusion. May we conclude that Poor Law adninistrators were more brutal in 1800 than they had been in 1750 ? This is incredible in view of the fact that the sentimental humanitarianism of pauperising out-relief triumphed at precisely the same date. The use of child-labour in the early factories seems to have been due in part to the difficulty of securing adult workers. The use of water-power often made it necessary for the entrepreneur to plant his mill at a spot where there was no supply of labour. It was evidently far easier for him to import pauper children and house them in rough sheds than to provide the housing accommodation required by adult workers with their families. Moreover, it was hard to impose the necessary discipline of the factory on adults who had been accustomed to the licence of a domestic industry. It was, therefore, in some measure the misfortune of the early manufacturers that they were driven to the alternative between using the worst and most thriftless trpe of casual adult labour and ning children. The evil once started tended, of course, to perpetuate itself. Is factories more and more came to compete with domestic industries, parents thrown out of employment or their wages reduced by machinery were compelled, by hunger, to send their children into the mills. The rising industries were organised on the assmmption that a large proportion of children would be employed, and it becane more and more difficult to retrace the fatal step.

There were, of course, individuals who understood, and pointed out from the first the evils of the new system. In regard to the (mployment of chiblien later experience has added little to the conclusions reached by 1 r. l'errival, at Manchester, as early as 1784 , and indeed the begimnings of legislative action go back to 1802 . But the matter was not taken scriously by any large body of opinion 
until a later date. Even at the present time it is treated in a piecemeal and somerhat haphazard way. It was, perhaps, even harler to deal with the evils of town life than with those of employment in factories and mines. The latter could be checked by pressure from the central government on capitalist owners; the former pos. tulated a considerable reform in local government, coupled with a particularly efficient central burcaucracy. Neither of these changes was immediately thinkable in the England of the Napoleonic wars.

Yet it is doubtful whether any one among these other evils inflicted as much suffering on the country as did the administration of the Poor Law. It is, of course, true that had other evils been absent the harm from this cause might have been relatively small. Poor Law reformers looked upon the years from cilbert's Act in 1782 to 1795 as marking the division between tolerably good and intolerably bad administration ; and it is true that some of the worst evils appeared after that date. But the cardinal evils, lack of system, lack of responsibility, and lack of central control go back much farther ; they originate in the breakdown of personal government in the seventeenth century, and reformers, all through the eighteenth century, were striving to find a remedy. The causes which led to the principle of the workhouse test for indigence of the able-bodied in 1722 were roughly identical with the evils which brought opinion back to the test in 1834 . As early as 1753 Fielding could write: " That the Poor are a very great burden, and even a nuisance to this Kingdom ; that the laws for relieving their distress and restraining their vices have not answered those purposes; and that they are at present very ill-provided for, and much worse governed, are truths which every man, I believe, will acknowledge." The Poorrate for England and Wales, which had averaged $f_{6} 689,000$ in the years 1748-50 had risen to $\$ 1,521,000$ in 1776 , and averaged $£ 1,912,000$ in the years $1783-4-5$. We may conclude that it was not merely change of system which raised expenditure to $f 4,077,000$ in 1803 , and kept it above $f 6,000,000$ on the average between 1820 and 1830 .

But though the Speenhamland resolutions at most only intensified evils which had long existed, the reformers were right in concentrating their attack upon them. Through them it was possible to hit at the criminal opinions which gave them birth. From the feudal conception of labour, as bound in duty and loyalty to 
work for its lord, emplovers and landowners had gradually come to regard themselves as charitable benefactors of the poor, for whom they found employment. This confusion of thought was an unfortunate misconception of the aims of Elizabethan legislation ; men failed to detect the distinction drawn therein between charity to the incapable and employment for the capable, and lumped them together in their conception of poor relief. Hence the practice which marle giant strides at the end of the century, and of which the speenhamland scale is a typical example. of paying not wages proportioned to the value of the work performed, but alms proportioned to the clam of the worker (apart from his efficiency) on social simpathy. The system pleased the majority of almost all classes. The humanitarians found in it merey if not justice. The selfish congratulated themselves that if the scheme was merciful it was at least not liberal. The employer saw his wages bill reduced by the rates, the ratepayer saw the rates reduced by the wageparments. The labourer was safe from hunger and could work as negligently as lie chose. Parents no longer felt the burden of their children, and children were relieved from dependence on their parents.

The most important ways in which the administration of the Poor Law became entangled with the industrial organisation of the country were the leasing out to entrepreneurs of quasi-servile faupers, and the direct or indirect subsidising of wages. In agriculture both methods were wiklespread. In the system of "roundsmen" we find the l'oor Law officials allotting able-bodied labourers to farmers, pro rata, so that each emploser escaped some part of his rate in return for the employment which he furmished. Ieain, a road-contractor could hise cheap' pauper labour, or a workhouse contractor could make his profit partly out of a direct subsidy paid him, partly out of the proceeds of the work done in the house. On the other hand the Justices fixed scales of wages varying in reference to the price of corn and the size of the wage-earner's family, the difference between the wase paid by an employer and the scale being matle up by a farment in money or kind out of the rates. The mone parment was the more usual, hut provision of house-room at the pullic expense was common.

Where such sthemes were adopted it was difficult for free to compete with pauper labour, for the pauper could afford to work 
for any wage offered by the employer, being sure of an adequate subsidy from the rates. Free labour could, indeed, offer extra diligence, but long before employers generally became aware that pauper labour was inefficient the harm had been done. In many districts almost all the casual wage-labour had been forced on the rates. It was even sometimes found that a man could not get employment at all until he was destitute, however low a wage he might be willing to accept. For if a labourer had a little property, employers sometimes argued that he could not become chargeable until he had spent it all, and that, therefore, the rates would be kept down for the time being by their employing paupers and compelling him to live idle.

The effects on those relieved were, first, to promote inefficiency and laziness, since a man's wages were no longer determined by his value to his employer; secondly, to encourage large families, an extra subsidy being paid for each child, legitimate or illegitimate, and it being impossible to prevent some part of the subsidy from finding its way into the personal expenditure of the parent.

It is very properly urged that the evils set out in the Report of the Commission of 1834 were those of the system at its worst. Generally speaking the harm done was greater in agricultural than in urban communities, and in the south of the country than in the North. It should, on the other hand, be remembered that the Commission's main business was rather to diagnose a disease than to estimate precisely the extent of the infected districts. In the case of a cholera epidemic we should not be so far comforted by the reflection that it had not yet spread to certain districts as to refrain from introducing improved sanitation in non-infected as well as in infected areas. The force of commonsense conservatism had been adequate in some places to prevent, down to 1834 , the worst evils of pauperisation. But the Commissioners had ample evidence of the rapidity with which evil results could outdistance good when once they got the start to warrant them in recommending drastic remedies. Unfortunately, as Dickens remarked, their handiwork " failed in its terrors for the professional pauper," struck "at the stricken sufferer," and was "a horror to the deserving and unfortunate." 1

\footnotetext{
1 “Our Mutual Friend," Book III, Chap. VIII.
} 
Between 1815 and 1832 the main lines of impending reconstruction become apparent. First, and before all, there is a rapidly growing percelrion that the existing political machinery was inadequate to carry, let alone arministrate, the needful reforms. In addition may be noted the denands of the indiridualists for reform of the tariff ${ }^{1}$ and reform or abolition of the Poor law ; the agitation of Robert Owen in farour of factory legislation; and the recovery by the wage-earners of partial freedom of combination. Of these the first two were cortain of acceptance by the classes which gained the rote in 1832 ; they had all to gain and nothing to lose by both. The third could depend upon the gathering body of humanitarian feeling, and what survived of older presumption in farour of paternal action by the state; opposed to it was the " sinister interest" of a minority which possessed, however, great political influence; it had also to cope with the explicable dread of such legislation as might reduce the earning power of adult workers by restricting industrial freedom. The last was opposed alike to the interests of the Whigs and to the instincts of the Tories; its strength lay in the misery of men who had no votes, and the devotion to principle of philosophic Radicals.

1 A practical leginning was manle by lluskisson in 1824-5. 


\section{CHAPTER IV}

THE ECONOMIC STRUCTURE OF MODERN ENGLAND

POPULAR thought has rightly seized upon capitalism as the keynote of modern economic life. The facility with which wealth can be borrowed and applied to increase production does now what at other periods in the world's history has been done by religious fervour or personal courage. It is a lever which individuals use to alter the state of society.

Until the close of the eighteenth century capital was almost entirely personal: in other words the capital employed by an individual trader or producer was his own. Joint stock complanies were exceptional ; where individual capital was inadequate recourse was had, usually, to a more or less complicated partnership; it was in this way, for instance, that Arkwright established the enterprises which made him a millionaire. During the nineteenth century, capital became increasingly impersonal-so much so that we are in danger now of forgetting that the farmer and the retail shop-keeper are capitalists. It is impossible to say, even approximately, what proportion of the capital employed in the country is owned by the inclividuals who direct the enterprises in which it is engaged: it is, however, likely in the future as in the past to become a smaller iather than a larger proportion. It is therefore peculiarly important to trace the growth and nature of the institutions by which capital is collected and distributed, and to understand clearly how what has been saved by one man comes to be used productively by another.

If we start from the end of accumulation we may make a broad distinction between the system of investment and the system of deposit. In the former case the capitalist chooses for himself the object to which his capital shall be applied. In the latter case he leaves this decision to a middleman. In either event the result is that the capital will be employed instead of being hoarded.

We have seen already that at least as early as 1720 there existed in England a considerable class which was prepared to invest money in response to advertisement. Partly, however, as a result of the repressive legislation, which delayed the growth of corporate 
enterprise, the investment habit harl little importance for the economic life of the country until the close of the eighteentl century. There were, it is true, the Bank of England, the East India and Hudson Bay Companies, and a number of insurance companies whose stocks were quoted and dealt in, but the number of such enterprises did not grow rapidly, and the capital of those which existed was not often increased. Practically the steady growth of the Xational Debt was the only opportunity for the investor who did not wish to play any appreciable part in managing his property until the great canal morenent which followed the early achievements of Brindley. In spite of the increase of large-scale manufacturing between 1760 and 1830 , the corporate form was seldom adopted. 1 company was formed in $176+$ with a capital of $f 100,000$ with the object of manufacturing cambrics; and we may note again early in the nineteenth century the semi-philanthropic enterprise promoted by Owen for the purchase of the New Lanark property, in which Bentham took shares. These examples, however, were not generally followed, nor indeed could they well be in the existing state of the company law. It was again to transport that the comintry owed its second great experience of the application of joint-stock capital to productive enterprise. By 1846 the mania for railways reached its height. A further extension of the investment field was cansed by the removal of the Bank of England's privilege (1826 and 1833). Changes in 1844. 1855, and 1862, removed the embargo on the company form, which had existed since 1719, and these changes caused, at length, a rapid extension of joint-stock enterprise. I'nblic borrowings have, of course, continued to form one of the principal channels of investment. From the close of the Nafoleonic wars indigent states thronghout the continents of Europe and America found willing creditors in London. In addition to the cost of wars and military preparations, an chormous amount of capital has fomel its way into remmerative undertakings. In England, although sine 1815 there has leen mo net adclition to the Xational 1)ebt, local anthorities have borrowed largely (in part for reporeluctive melertakings) during the past forty years.

The method of attrating investors has varied: but so far as

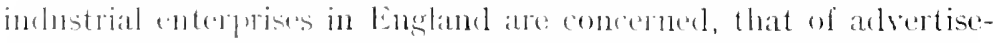
ment by prosprectus has usually prexteminated. On the one hand the English joint stock lanks are so dependent on deposits that 
they view company promotion with suspicion; on the other, the habit of investment became so early rooted in the country that the direct appeal for funds has in general succeeded only too easily. The matter of appealing to the public and attracting subscriptions has, of course, become more and more of a special business. The process is admirably explained by Mr. Hobson, who tells us that the man with a vendible "notion " "must have recourse to the assistance of general financiers who are able to put 'such notions' on the market in such a way as to tempt the investing public into buying." 1 "The limits of the sound and useful service of the promoters and financiers in constructing and in floating a companyconsist in a just calculation on actuarial and other bases of the future earning-capacity of the business, its capitalisation upon these bases, and the distribution of the stocks and shares, and their marketing in forms most convenient to the investing public, who are informed of the true nature of the business into which they put their money." 2 It is hardly necessary to point out that the accumulation of investment capital has been further aided by the development of varions classes of shares and securities suited to the needs of investors of various types, and by the development of wide markets where these instruments are dealt in. The London Stock Exchange Society, which we saw at work in an eighteenth century tavern, opened buildings of its own in 1802; local exchanges have arisen in the principal manufacturing and commercial towns; and the telegraph has made possible a world-wide market for the most important securities, whose prices in turn affect the prices of those whose market is merely local.

Turning now to the method of deposit, it appears that until 1830 English banks depended chiefly upon their note issue, although in London the deposit and cheque system was already developing rapidly. The rise of joint stock banking, between 1840 and 1850 , coupled with the close restriction of the note issue since 1844 , has thrown upon deposits the work of distributing the capital required for short period operations. A very small part of the banking deposits of the country is traceable ultimately into the gold reserve at the Bank of England; a further proportion finds its way either by direct investment on the part of the banks or by loans to Stock

1 "Evolution of Modern Capitalism," p. 239.

2 Ibid, p. 245 . 
Exchange speculators into fixed capital or public loans; but the English banks have retained, as their primary business, the provision of circulating capital for industry and commerce.

The machinery for collecting and borrowing capital, which has thuts been provided, has led to a great increase of indirect methods of production, whilst on the other hand, of course, the superior productivity of such methods has stimulated their growth. The general course of this development is a mere continuation of the movement described in an earlier chapter. ${ }^{1}$ It resolves itself into production on a larger scale with the aid of elaborate plants and bodies of regimented workers, involving on the one hand extreme localisation, on the other a great proportional increase in the work of transprortation and dealing. Wherever these tendencies have been active, control of the economic life of the country has passed into the hands of a comparatively small number of individuals. ${ }^{2}$ Potentially, and to some extent actually, it has passed by the same process into the hands of the State. ${ }^{3}$

The actual growth of large scale undertakings has been so great that there is a real danger of exaggerating its importance. It should be pointed out, therefore, that although English statistics are inadequate to guide opinion on the matter, there is strong evidence from the United States of the vigour of small undertakings in certain cases. There is no reason to suppose that individual independence-whatever its ultimate fate-is being at present at all rapilly crushed out of the economic worlel. In many manufacturing industries, in transport, finance, and distribntive trade, the victory of large scale organisation is assured; the principles of standardised production and divided labour are or will be applied in all possible directions. Where, on the other hand, each of a nmmbre of similar articles or services must be varied more or less to suit the consumer, the independent producer continues, and will continue, to flemrish. The interest of these facts for the historian lies in the guestion whether, as a whole, growth and changes in

1 Book IV, Chat). 11.

2 Nominally, of course, the company system reelistributes control throughout the share-hokling public. But in practice companies are governed by a tiny minority of the shareholelers with almest alsolute p.ower.

"Thus whilst it walk le quite impossible to control the quality of beer brewed by each of a number of fomilies for demestic consumption, it is not at all impussilu. on control its quality if hrewed for all the families at a single brewery: 
consumers' demand have been favouring one or the other form. During the past century there can be little doubt that in England, as elsewhere, they have, on the whole, favoured the former. In very many cases the standardised article so produced has been superior to its predecessor. In other cases national taste has shown its incapacity to resist a real deterioration in consumption. There are, however, signs already that an increasing proportion of the wealth of the country is likely to be spent in the future on objects which cannot be produced, at least in their final stages on a large scale.

The largest single enterprises so far have been found in railway transport. The early railways were established on the pattern set by the canals; thus the line between A and B (two important centres) was often independent of the line between $A$ or $B$ and any third important centre C. Moreover, although elaborate goods and passenger services were provided by the railway companies from the outset, it seems that some people anticipated that private individuals would run independently over the companies' lines. The numerous small lines soon coalesced into a small number of great ones, by whom amost exclusively extensions were molertaken ; and although private firms have always provided a part of the rolling stock, motive power has always been supplied by the companies alone. The concentrative tendency has shown extraordinary vigour in banking since the initial mistake of opposing the company form was abandoned. In the last thirty years the number of banks in England and Wales has been reduced by fusion from over 300 to about 50 , and is still falling at the rate of some seren a year. Meantime, of course, the number of bank branches and the total funds employed has increased far more rapidly than the population of the country. A similar tendency is shown in life, fire, and accident insurance.

In industry considerable progress has been made in substituting the factory for the domestic type. Cotton and woollen weaving, nail and screw making, boot and shoe making, have been taken over in whole or in great part since 1830 . The process can be seen at work in many industries at the present day-e.g. ready-niade clothing. There are, however, forces working in the opposite direction, and promoting the growth of small businesses. They have secured the major part of the enormous amount of repairing which the 
modern tendency towards cheapness entiils, ${ }^{1}$ and although the domestic system has almost disappeared in rural districts, it holds its own in most large towns in the field which is roughly designated as that of "sweated industry." Where the factory was already the unit seventy years ago, increased size can generally be predicated with conficlence, though statistical proof can seldom be adchuced. In some cases a real adrance in the scale of production is achieved with relatirely little alteration in the quantity of capital employed in cach business, by reducing the number of processes carried on within a single factory, or the number of types of commodity produced. Throughout the textile industries there has probably been enlargement of the normal unit in both ways. On the other hand, increase in the scope of the individual business often entails larger capitalisation. We have seen that integration of processes was aheady a feature of the iron and steel industry during the industrial revolition. We find now firms which own their iron and coal mines at one end of the series and tum out finished ships at the other.

In agriculture the tendency towards the forming of larger farms which was observed above continued until the ent of the 'serenties, -as long, that is, as the production of cereals and meat by largely routine methods remained in the ascendant. Since then the balance of forces has swung rather in favour of smaller areas and capital with intenser personal superrision on the part of the manager. In commerce several competing tendencics deserve recognition. First, the growth of organised markets of dealers analogons to the Stock Exchange. These are most marked in the supply of raw materials to the staple inclustries and of the staple forms of forst-the markets in cotton, wool, pig-iron, and wheat may serve as examples. In all these cases a number of producers, too great to combine easily, are connected with a number of consmmers similarly situated by independent dealers, who nomally take risk and tromble off the shomlders of both parties, and occasionally injure them when the gambling instinct gets the upper hand. Secondly, we note the progressive absorption of the comnercial function by the producing business. The commercial traveller with patterns displaces the independent merchant; though

\footnotetext{
1 In so far, lowerer, as such work has leen tilken over by small specialists from the tamily it must lec comnted as relatively large scale production.
} 
he retains, by the commission system, an interest in the business. Further, the simple despatch of patterns, facilitated by improved transport and by the telegraph and telephone, displaces the commercial traveller. Again, the retail shop falls into dependence and sometimes becomes a mere deprartment of the concern which produces the most important goods sold there. Thus public houses are "tied" to breweries, boot shops to boot factories, etc. Still commoner is the growth of the large-sized retail business, seen sometimes in the great store which retails an enormous varicty of goods, and again where a number of branch shops are established by a single firm. Finally it seems probable that the organisation of domestic industries has been shifting, its control passing into the hands of a proportionately smaller number of traders. The furniture and clothing trades, for instance, in large towns tend to pass into the hands of a small group of large retail establishments which farm out to masters the actual organisation of production, these last in turn spreading the work to be done amongst the actual employees. It is probably due to this that the domestic industries grow more and more specialised; the indiridual worker makes part instead of the whole of a piece of furniture or a garment.

The cheapening of transport and the ease with which capital can be procured to extend or institute production at any desired spot have completed the destruction of the self-sufficing character of the village unit. The same causes have operated to bring about a somewhat one-sided development of manufacturing and mining as compared with agricultural activity-a state of things which must be expected to continue until the population of the "new" countries has become appreciably denser." We sum the matter up by saying that business has become more competitive. Every producer of commodities which will stand transport must face competition over wider and wider areas. If at any point of the market area it suddenly becomes possible to produce more cheaply, the ease with which capital can be applied will shift rapidly to that point and away from others the production of much, or the

${ }^{1}$ It seems clear that English agriculture is also hampered-how much it is impossible to say-by the comparative inferiority of the English land system. We have neither the "free" land of new countries, nor the co-operative organisation of some old ones-c.g. Denmark. In addition the use of land for political, social, and sporting purposes restricts its procluctive employment. 
whole, of the commodity in question. Competition has, of course, been further intensified by the fact that in an increasing proportion of productive operations an increased output can be produced at less cost per unit.

But whilst, without question, the intensity of competition has increased upon the whole during the past century, other sides of the economic transition tend to eliminate or reduce it in more and more cases. Where enlargement of the mit of production jroceeds more rapidly than the growth of the market, the number of competitors is steadily reduced, and this lessening of their numbers makes agreement to limit competition more and more feasible. Apart from reduction of numbers it will generally be found that any trade which has been organised in a particular way for a lengthy period will gradually develop a custom which effectively limits competition. Such customs are not, of course, to-day sanctioned by law as were the similar arrangements of the Middle Ages, and it may be admitted freely that ther are far less detailed, but of their existence and real importance there can be no question. The elaborate arrangements of the Micklle Ages, which were intended to secure the adrantages of a known and open market, are of course largely replaced to-day by the ubiquitous activity of journalists; but all the great bodies of dealers do in one way or another levelop customs which permit of the operations of the individual becoming known, and subject him to caste-opinion.

We shall deal in subsequent chapters with the special machinery which has becn built up to regulate the wage contract, but a few words may be adeled here on the subject of agreements between producers. Starting from informal price agreements, such as those which exist between retail traders in a fashionable suburb, we can find more and more complicated arrangements for limiting prices ancl controlling outpht, learling up to the ideal of amalgamation. These tendencies have shown themselves strongly, as might have been expected, in the inclustries particularly given over to large scale organisation. We have noted abready, in regard both to raibways and banking, hrow fusion has reduced the number of competitors, and how extension has ban kept in the hands of existing concerns. In the railway work wery great pregress has been male towards a commen d.temination of freights and the porling of traffic in cortain cases, hut wing to the practical 
impossibility of grading railway, and especially passenger service, ${ }^{1}$ competition is ultimately more restricted by informal nuderstanding than by the precise arrangements as to rates. In the English banking world no definite agreements as to charges to the public have yet been reached, but the general training of the banker and the atmosphere of the profession are intensely opposed to sharp practice in the fight for clients. The reduction of the number of banks has made common understanding more possible, and, indeed, at times of crisis the London money market has generally retained enough of medieval civic feeling to act as one man. ${ }^{2}$ The history of professional custom in Banking is complicated, and a certain cross-current of influence is observable in the nineteenth century. The rise of joint stock banking has resulted in the abandonment of some features of the gentlemanly tradition, ${ }^{3}$ and probably the majority of bankers believe that they are face to face with keener competition every day. In a sense this is true, but it is also true that they are developing quite rapidly enough the power of checking undue competition, if not of acting monopolistically. Conditions in the iron and steel industry have becn, from an early date, favourable to restrictive agreements. Is carly as the sixteenth century it was distinguished from almost all other industries by its relatively large-scale production. The following passage from The Iron and Coal Trades Review shows the situation in those trades in 1898. "We have now in operation agreements or understandings as to prices in the rail, ship-plate, boilerplate, bar-iron, and other branches of the iron and steel trades of this country by means of which prices are fairly well maintained, and cutting is largely prevented." + More elaborate arrangements by which output as well as prices was regulated

1 The price per mile can, of course, be easily settled - but the price of what? It depends on speed, comfort, convenience, safety-in other words, lehind a price agreement competition can proceed indefinitely. It cannot, hwever, be to the same extent of the snappy chastic character which is most injurious to efficiency. Prices, if left free, can he shifted up or down by a mere arithmetical process; more comfort, etc., means elaborate thought and expenditure of capital, and will therefore only be introduced slowly and judiciously.

2 Tevertheless it is only within the last few years that the Bonk of England has been able to depend upon the support of Joint Stock banks in the maintenance of the discount rate in critical times.

${ }^{3}$ There is, for instance, much less reluctance now to seek out custom than there was even thirty years ago.

"Quoted Macrosty, "The Trust Movoment in British Industry," 1). 67. 
were adopted by the "Bedstead Alliance " of Bimingham in 1890, by the dyeing trade in the West Riding, and by some other minor inclustries. Most of these arrangements have since then broken down. In only a few cases has an effective trust been established in England, but in a number of important industries events seem to be rapidly approaching the point at which control of output and price policy will be centred in the hands of a small committee, even if existing concerns are not formally amalgamated. These tendencies are most noticeable in the industries already discussedriz., Railwars, Banking, Iron and Steel-but they are seen also in a number of minor manufactures and in the (quantitatively) firstclass industries of Brewing, Music Hall Entertainment, and the Press. In other industries there is always the possibility of the rise of more democratic associations to deal with particular problems of general interest. Thus the Lancashire cotton industry can ahcady arrange to limit output by working short time, whilst the development of new cotton-growing areas within the British Empire has had some of the aspects of an undertaking common to the whole trade.

The general course of economic history shows clearly that where economic conclitions are such as to make it possible for individuals to manipulate production and sale arbitrarily to their own advantage, society re-acting to the attack developes institutions which purport to control and prevent these evils. In England, during the past century, the problems raised by the threat or existence of monnoly have been dealt with in two chief ways, by regulation of the terms on which the monopoly may trade, and by substitution of collective for private enterprise. Progress. of course, has been most rapid in cases where some overt act of the state was required to cnable the cnterprise in question to exist at all. Railways, water-works, gas-works, ctc., have been obliged to apply for special powers to the central or to local authorities, and the public has, therefore, enjoyed a strategic advantage in making terms with them or displacing them. In the case of railways a certain control of prices has been retained. In the case of some gas-works the public authority has attempted to secure a share in any profits beyomel the fixed minimum. The boly of opinion, however, which favours public ownershy) and management as compared with regulation has steadily gained strength, and this is especially 
evident in respect of local monopolies. The decisions of local authorities are less influenced by general principles than are those of the central government, and they are only beginning to feel the pressure of excessive business which curtails the activity of Parliament.

The danger of monopoly is, of course, only one reason, though by far the most important, of intervention by the State between producer and consumer, or of public enterprise. One or the other method is increasingly adopted to restrict the sale of articles which are not what they purport to be. On the one hand we find the list of prohibitive legislation growing steadily longer; on the other, machinery is being gradually devised for enforcing the cole. And where neither law nor inspection secures, or seems likely to secure, the desired end, a particular economic function-e.g., provision of abattoirs-may be assumed by the public. Thus, although the process defies measurement, there is an evident tendency for the control, and to a less extent the management and risk, of economic enterprise to be transferred to the nominees of public bodies and trusts. The history of the movement, up to the present time, supplies no reason for supposing that its extension over the whole field of large scale enterprise is technically impossible, although in practice, no doubt, our existing political machinery is entirely inadequate to such an extension. ${ }^{1}$ One of the chief dangers of the situation is that undeserved failure will befall experiments, not because they are themselves undesirable, but because the average individual is more interested in promoting some concrete scheme than in devising machinery which would enable a largely increased burden to be borne efficiently by the public authorities.

The collectivist tendencies which have been examined in the preceding pages are to be regarded as developments in econonic structure whose roots can be traced far back into the past. The public ownership and the rules for the use of roads postulate theories of the relation between the State and the individual in economic matters which can be stretched to cover them all. In regard to any one of them the only question which deserves consideration is whether the facts of the case were such as to make the application of those theories desirable. In the same way the expansion of

1 This seems clear from the comparatively small share in the movement which the central govermment has taken as compared with local authorities. 
co-operative enterprise which has occurred in the past sixty-five years can be connected with earlier precedents. though that which is new in it is probably more important than that which is old. In 1795 a corn mill was erected at Hull out of general funds and worked on the principle of supplying flour at a price which just repaid outgoings. and it is to this and a few similar experiments that the commencement of the co-operative mosement is usually referred. They are, however, in some respects more analogous to the municipal granaries of the fifteenth and sixteenth centuries than to modern co-operative practice. From another point of view modem co-operation may be regarded as a substitute for the element of subsistence production in the lives of the masses which had been made unnecessary or impossible by the industrial revolution.

The co-operative movement has a consecutive history from the agitation of Robert Owen onwards. The experiments carried out by Owen at New Lanark between 1812 and 1829 anticipated the best features of State and municipal collectivism at the close of the nineteenth century. The regulation of factories and lousing and educational and social work of all kinds were there first elaborated in consonance with a reasoned belief that human beings repay in rarious ways expenditure which derelops their faculties.

Among the improvements introduced at New Lanark was a store which supplied goods to his wage-earners below the prices charged by local retailers, and yet left a surplus which was expended on education and other social objects. His later experiments in the organisation of gromps of co-operating prodicers, who exchanged the product of their labour on the basis of a schedule of "labour" values were less successful in themselves, though of enormous inportance in popularising the iteal of co-operation throughout the Xorthern counties. Co-operation as an effective movement begins with the fonnding of the "Pioneers" Society in Rochdale in 1844. The ir ideas were those of leobert Owen. Their original rules provide that as soon as prosible " this Society shall proceed to arrange the powers of production, distribition, education, and government," or in other words to estahlish a self-supporting home colony of uniterl interests, or assist other societies in establishing such colonies. Nhantime, with a rapital of f28 subseribed among themselves the members openert their "store," which although not actuatly the earliest to exist contributerl more than 
any other to launch the movement. They adopted the plan, which became a fixed principle of the movement, of charging competitive prices for their goods and paying out of the profits a dividend to members proportionate to the purchases they had made. From the same fund were drawn the amount of common expenditure for educational or social purposes. The success of the "Pioneers" caused the system to spread rapidly in the Northern counties. Besides retailing goods bought wholesale, many stores started tailoring and boot-making departments. In 1864 the Co-operative Wholesale Society was founded. Individual stores joined together to furnish the necessary capital, and the same principle of selling at market prices and distributing profits in proportion to purchases was followed. The Society grew rapidly, and in addition to its commercial business has undertaken manufacturing, transport, and banking for the movement on a considerable scale.

The success of the movement seems to have been due to the following causes. (a) The economy of eliminating much of the expense of attracting custom. The members of the Stores furnish a far more stable and measurable demand than that which the private trader has to meet. Advertisement and window-dressing in all its forms are reduced to a minimum. There is less need for a constant variation of stock. (b) Aroidance of fraud and adulteration. Since the consumers, as a body, manage the business, they can be more certain individually of actually obtaining the article for which they pay, and not some inferior substitute. Economy in the cost of labour. Managerial ability is probably secured on considerably lower terms than are usual in private trade. The democratic organisation of the movement opens up a very large field of choice among men whose class standard of income is low, and who in many cases are interested in the morement, and willing to give their services for low salaries. On the other hand, serious charges are brought against co-operation by private traders. It is alleged first that secret commissions are habitually accepted by many officials, and secondly that the prices charged are normally higher than those of the retailer by at least as much as the dividend returned to the consumer. Neither of these charges can easily be investigated. As regards the former, it may be noted that the evil, so far as it exists, is more likely to be talked about in co-operation than in private business, both because of the publicity which 
ineritably forms a feature of a democratic organisation, and because private traders have a direct advantage in exposing it. Further it is believed that the eril has been greatly reduced of recent years. As regards the latter, the establishment of peculiar types of co-operative goods makes direct comparison between prices in stores and private shops increasingly difficult. It is certain that in general the charge is exaggerated, but much depends on the particular store and shop which are selected for comparison.

The distributive movement attracted considerable attention among the Christian Socialists (Maurice. Hughes, Kingsley, and others), and did not altogether satisfy their ideals. Casting back to the teaching of Oren and influenced also by the experimental workshops set $u p$ at Paris in 1848 they favoured a re-organisation of industry which would enable the wage-earner to become his own employer. They financed a small number of businesses in which the wage-earners were organised with a view to their owning the capital employed and appointing the manager. Many similar experiments have been made in the past fifty years, and the Labour Co-partnership Association, founded to federate and promote such enterprises. draws its inspiration from their teaching. The difficulty of securing efficient management under this system is obvious, and the economies which it purports to secure by interesting each worker in the success of the enterprise have proved. hitherto, less important than those attained by the distributive branch of the movement.

The relation of these divergences from the main type of individualist enterprise to the creed of Socialism is exceedingly interesting. Those who recognise most fully the social benefits conferred by competitive service are enomraged to hope that where competitive service degenerates into competitive framd, or is impeded by indivichal agreement, the State or associations of indirictuals may secure equivalent benefits by a more direct route. On the other land, the interest of concrete achieventents is turning Socialist thought away from the speculations in which it originated. The lines upon which municipal socialism is proceeding have as little redation to the theory of value proponmeded by Marx as they have to the theny of ralue propounded by Ricardo, and modern cooperative practice las not much more affinity to the theory of Robert Owen. It is, in faet, increasingly difficult to determine 
whether this growth of collective enterprise can best he described as dereloped Individualism or incipient Socialism. The name, in itself. is of course, immaterial ; but some confusion of thought is likely to ensue when the spread of municipal Sociatism, i... the public ownership of streets and gas-morks. is accepted as evidence of the spread of opinion farourable to such "Socialism" as e.g.. equal remuneration for unequal services. or uncompensated expropriation of landowners and capitalists. 


\section{CH.IPTER V \\ THE STANDARD OF LIFE}

We have alrealy traced briefly the recovery by the nation of conficlence in the power of collective action to check evil and promote good. Partly to this recovery, partly to the peculiar conditions of modem life. are due the boly of opinion favourable to State ownership and management of industrial undertakings. and the practical steps which have been taken towards that end by local authorities in the past fifty years. Hore important, however, than incipient socialism or municipal trading-at least in their existing dimensions-is the bedy of law and discipline controlling the material aspects of life, and the economic relations between individuals. which has been gradually built up. It seems almost as though the mass of men and women, without any conscious theorising. lras come to riew liberty in Aristotelian manner as a mean between extremes. Certainly modern practice more and more implies the assumption that liberty can only be maximised by all-pervasive restraint. Modern Collectivism. however, goes much further than nere inbibition of the individual from actions which are judged likely to injure others or injure himself. In addition to negative restraints it imposes an increasing body of positive obligations. Men are compelled not only to refrain from buying and selling labour on certain terms. but to subscribe to a common expenditure whose aim is to diminish the suffering and injury inflieted by porerty. The growth of these purposes can be viewed very clearly in the history of two departments of State activity. the relief of porerty and the legal regulation of factories, mines. and workshops. The history of these two matters contains the key to the morement of opinion in numberless others.

We have glanced alreaty at the hinal degradation of the Elizalethan Pon law after 1795 . It was peculiarly unfortunate that the period of this degratation colncided with the intedlectual triumple of Individualiom. If the evils of the system had heen less

1 It must, of course. Bu arlmitted (as was noterl carlier) that the inefficiency

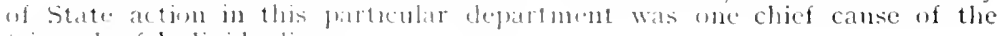
trimente of lodjoinlualism. 
flagrant more attention might have been paid to the problems which it was intended to cure bnt which it in fact accentuated. If opinion had been less indivitualistic the facts of the sitnation would have been viewed with less bias. As it was men were prepared for a desperate experiment, and the experiment which was made was based on a partial and inadequate analysis.

No serious remedy was attempted before 1835 , though educated opinion was gradually prepared for the need of reform by the writings of Eden, Arthur Young, and. above all, Nalthus. In 1817 a Committee of the House of Commons pointed out some of the worst evils of the existing policy, and made some valuable suggestions. with no result on the general system, though legislation was passed which permitted improvement in a few places where public opinion was capable of taking the initiative. What was needed, however, was not merely provision of facilities, but enforcement of their adoption. It was necessary to create machinery which would take up the work of supervision and stimulus from the centre. which had been left undone since the decay of personal goremment in the seventeenth century.

The report of the Poor Law Commission of $183+$ was probably written by the economist Senior. The anthor showed an immense power of digesting detailed evidence; he demonstrates his main conclusions inductively, whilst insisting that they are such as might be deduced from familiar facts of human nature: his work has an artistic unity, and at times a finish of style, which are seldom met with in our blue-books.

The cogency of style, no doubt, accounts in part for the hold which the Report took upon its realers. On looking back it is evident that its underlying ideas, which are assumed and not proved, were those of Senior's class contemporaries. It is a demonstration from experience of the evils of certain forms of out-relief, and an appeal against out-relief in all possible torms: it is pervaded by an impassioned assumption of the all-sufficiency of self-respect, provided it is not undermined by State aid. Briefly: the author recommends immediate cessation of out-relicf to the able-bodied, and its restriction, in the case of those not ablebodied, within the narrowest limits. The workhouse standard of life is to be made adequate to prechude such physical suffering as outrages humanity, but at the same time so irksome as to interest $19-(149)$ 
the individual in aroiding it. The hope for the future is that thrift and self-reliance will be so stimulated as to make relief ultimately unnecessary, even for old age and sickness. The logical defects in this thesis are plain enough. If we are justified in leaving the pauper to mental and esthetic torture with a riew to his moral improvement. why should we boggle at the wind and the rain? The only answer is that "hmmanity" insists. But why make the "h" in humanity just so large and no larger? If we answer that we know we are illogical, and prefer to be so, still more serious difficulties remain: if the workhouse test preserves some men's characters by keeping them off the rates, it may injure those who are led thereby to suffer a breaking strain of privation and those who. yielding to the test. are hranded henceforth as paupers. Behind these questions lies the larger problem of responsibility. In sympathy with the atomistic view of society which ruled at the time, the reporter hardly recognises any equitable clain of the indigent on society. Yet it was part of the case set forth in the report that the existing pauperism in the country was largely the product of the existing Poor Law system; and if its author had examined industry generally. with the attention which he deroted to the Poor Law he might have drawn further conclusions as to the dependence of individual fortune on the structure of the social system.

The new machinery for administering and supervising relief was fairly satisfactory. At the least it was an enormous advance on what hat existed up to that time. Its general structure was simple. A number of elected bodies (Boards of Guardians) were to supervise the work of salaried relieving officers and workhouse officials: and these local authorities were connected by travelling inspectors with commissioners sitting in I.ondon, whose lousiness it was to lay down in detail the methord and scale of relief. The ad hoc principle was necessitated by the defects in the existing machinery of local government.

It is sometimes mogel in extenuation of the harshness of the reformed loor law that the situation was so bad as to require a drastic remedy. This may serve as an explanation, but hardly as an excuse. In fart, the extraragance of the reformers, so far from loring essential to their success, went near to defeating them altogether. For some years after the central board hat begun 
its work local opposition was so violent that it remained doubtful whether its policy could be permanently maintained. Nor is there any reason to suppose that the system has minimised pauperism, though it has undoubtedly prevented the condition of the nation from being as bad as it would have been harl the unreformed law continued in force. Its discouragement of application for temporary relief has been perhaps more effective with those who were likely to gain by help than with those who are likely to be pauperised by it, and the rule, once a pauper always a pauper, has still too few exceptions.

In spite of the writings of Dickens, the opinion of the governing classes continued to support the experiment for more than thirty years. There was, perhaps, never much hope ontside a few extremists that it would ever be possible to abolish indoor relief, but the expectation that it would be possible to dispense with out-door relief died hard. "As late as 1869 the central authorities struggled to increase the strictness with which outdoor relief was administered, and in 1871 Professor Fawcett, a fair representative of the economists of that day, still apparently advocated its abolition." 1 The Parliamentary and Municipal Registration Act of 1878 continued the effect of earlier legislation, which disfranchised indiscriminately all recipients of relief. The clrange of policy in this matter during the past thirty years has followed two distinct lines. On the one hand may be noted minor alterations in the Poor Law, and some change in the method of its administration ; on the other hand a series of proposals, and in some cases practical experiments directed towards the solution by other means of problems which had previously been dealt with, if at all, by the Poor Law authorities. As regards the former the principal change has been in administration. There has been some relaxation in the terms on which out-relief is granted, the comfort and cleanliness of workhouses and casual wards have been in many, pertraps most, cases much improved, and as regards children, considerable effort has been made to remove the pauper stigma, and in other ways lessen the chance of the contagion of pauperism reaching them. Of legal change there has been little. In 1894 an Act empowered guardians to give out-door relief to any member of a friendly society in receipt of less than 5 s. a week. In 1904 this

${ }^{1}$ Dicey, "Law and Opinion in England," 292. 
change was made imperative. As early as 1885 the receipt of ontrelief in the shape of medicine ceased to disfranchise. It is generally anticipated that the Report of the Royal Commission, now sitting (1908), will result in fundamental changes in the system. As regards other proposals and experiments, the most important relate to the following points: provision for old age, provision against accidents in the comrse of employment, remedies for memployment.

The movement in favour of old age pensions is particularly instructive. The heary expenditure incurred by Poor Law authorities in the maintenance of persons orer sixty or sixty-five years old is regarded as both extravagant and unjust. Extravagant, because the odium attaching to pauperism prevents the money from prolucing the maximum of satisfaction possible in those who receive it; unjust, because whilst money is spent upon relatively undeserving cases, on the drunkarel and the inferior, who have hinclered rather than helped society, it is denied to " veterans of industry" "who retain too much self-respect to enter a workhouse, or have scraped together a pittance sufficient to keep them out of it. Such views are, of course, a logical decluction from the view that the individual has a claim upon society for tolerable conditions of existence, ${ }^{1}$ and do, in fact, imply what is commonly called a "collectivist" attitude. The matter was seriously raised by Mr. Booth in 1892. ${ }^{2}$ It was considered by a Royal Commission in 1893, and by Lord Rothschild's " committee of experts" five years later. Both these bodies reported unfavourably. In the meantime it harl been made a serious question in politics by Mr. Chamberlain at the Cencral Election of 1895, and in 1899 1hr. Chaplin's committee reported that a scheme was prima facie possible. It seems probable that the expenditure on the Boer War alone prevented some action being taken by the Conservative covermment. A scheme was inangurated by the Liberals in 1908.

Employer's Liability. In the eighteenth century an employer was beld by the Courts to be liable for injury intlicted by a negligent servant on a third person; in 1837, however, it was decided that this liability dicl not extend to cases where the person injured was

i No dould many whe hold this view woukl vole against wh age pensions, (1) the ground either that the money regured could be better spent on other (1)jects, of that the inderect effects of oled age prensions would make life other wats more intolerable than it actually is, e.g., ly wealicumg family ties.

2" "Dauperism, a l'icture; and lindownent of (old Jge, an Argument." 
himself a servant in "common employment" with the negligent workman. This doctrine of "common employment" was not the subject of legislation until 1880. The Employers' Liability Act of that year restricted its operation, but did not prohibit contracting out. The Workmen's Compensation Act of 1897 made employers liable in many industries for risks run by their employees, whether resulting from negligence on the part of fellow workmen or not. It further forbade contracting out. Subsequent legislation has extended considerably the area of liability, and the number of industries affected. The Workmen's Compensation Act of 1906 , which came into force on the 1st July, 1907, has replaced and extended all the previous enactments.

Provision against unemployment other than poor relief, has hardly passed beyond the stage of minor experiment in labour exchanges, farm colonies, and subsidised relief works. These experiments commenced with attempts to mitigate abnormally severe distress, and have gradually developed in the direction of permanent measures. Charity has, no dould, at all times been quickened by any unusually dramatic distress, but it is only during the past thirty years that special "funds" have multiplied. The money is still in most cases extracted and spent under pressure, and, therefore, in the main badly spent. ${ }^{1}$ The idea that society should organise in advance against trade fluctuations had made little progress up to $1900 .{ }^{2}$ Even the Unemployed Workmen Act of 1905 is not unfairly described as " a tentative piece of legislation, which . . empowers certain bodies to try social experiments," 3 the cost being defrayed partly from the rates and the national exchequer, partly from voluntary contributions.

In summary, this brief analysis of the progress of thought and policy in relation to destitution testifies clearly to a change in the dominant conception of socicty. We find, first, growth of the belief that every member of a society has an equitable claim against it, if it acts so imperfectly that he cannot, by reasonable diligence and honesty, maintain himself and his family in tolerable comfort. Secondly, it may be noticed that a different view of the psychological effects of destitution and relief prevails. On the one hand it

1 The total thus wasted is not dangerously great.

2 It has, of course, been long a settled principle of Indian famine administration.

3 Brassey and Chapman, "Work and Wages," Vol. II, p. 369. 
is held that want is as destructive of character as charity, if it passes beyond that just measure of economic pressure which gets the work of the world performed. On the other hand it is thought possible that the relief of erils which are unaroidable by individuals of normal intelligence. character. and eaming capacity, may be so far assimilated to other sides of collectivist practice as to rob it of any deteriorating influence on those who are relieved. ${ }^{1}$

If we tum now to regulation of the conditions of employment we find a more considerable change in practice with an equally definite derelopment of opinion. The word " factory" first appears in English law in the Act of 1802, which dealt with the employment of apprentices in the cotton and woollen industries. Subsequent Acts, down to 1831 inclusive, had reference to cotton factories only. The Act of 1833 was still confined to the textile industries (except silk) and to those factories which employed water or steam power to drive machiners. This double limitation to the textile industries and to factories where power was emploved, appeared again in the Act of 1844 , the definition here being " all buildings or premises wherein or within the close or curtilage of which steam, water, or any other mechanical power shall be used to move or work any machinery employed in preparing, manufacturing, or funishing, or in any process incidental to the manufacture of cotton, wool, hair, silk, flax, hemp, jute, or tow, cither separately or mixed together, or mixed with any other material." In the next twenty rears print works, bleach works, and lace works were subjected to similar legislation, but the Acts in question were not entitled Factory Acts.

The Factory . Acts of 1864 and 1867 extended the term factory to inclucle all places where a manufacturing process was carried on by more than fifty persons. In 1867 began a series of Acts which extended the principles of factory legislation to places which were defined not as factories but as workshops-the dividing line between the two being the common employment of more or less than fifty wage-earners. Between 1870 and 1878 a process of codilication commenced. The Factory and Workshop Act of 1878 classifies places within its scope as follows: (1) Textile lactories. (2) Factories other than textike, (3) Workshops, (4) Workshops where neither

1 Thus it is often urged that the collective bearing of the burdens of uncmpleyment, accillent, illuces, destitule old age, etce, is strictly analogous to the collective learing of the cost of street-cleansing or road construction. 
children nor young persons are employed, (5) Domestic workshops. In subsequent Acts down to 1901 the tendency has been to recognise more and more fully the community of aim of the whole body of industrial regulation, and to use definitive terms such as factory and workshop merely as a convenient means of classifying the mass of material which requires to be dealt with.

The limits of comprehension and uniform treatment have not, however, ret been reached. On the one hand, the workers in some important industries, e.g., agricultural labourers, shop-assistants, clerks, domestic servants, stand as yet almost entirely outside legal protection: in other cases, e.g. mines, shipping, and railways, where a considerable body of regulation has cleveloped, it las not been incorporated with the general factory law.

This regulation of industry is evidently a product of the Industrial Revolution. Until 1830 it was almost confined to the cotton industry; for more than thirty years longer it was confined to large establishments, mines and factories, the typical product of the Revolution: and though since then it has struck back upon earlier industrial types, its influence over them is still far less complete than over the units of large scale production. Legislation originated in the perception that the use of power-driven machinery in the textile industries, especially at first in the industry of cotton, entailed evils for the employees which were beyond the control of the indiridual wage-earner. As early as 1795 a committee of inquiry at Manchester pointed out the destruction of health occasioned by the work in the cotton factories. The two points which most arrested attention were the extensive employment of children and young women in conditions which sacrificed physical and moral development, and the absence of the quality of necessity in the evil, for from the first a minority of the factories were well managed and deliberately accorded relatively good conditions, whilst in the industry, as a whole, the profits of enterprise and rewards of management seemed unprecedentedly high.

The children employed in factories at the end of the eighteenth century were still in most cases called apprentices, and often had been legally bound to their masters. The employer stood, at law, in the relation of parent towards them, and had the right to punish them, and set them their tasks as he thought good; in theory he was preparing them for life by teaching them a trade. 
Actually, in most cases, he was using them as a cheap and docile kind of wage-labour, and turning off into the ranks of casual labour most of those who lived to an age at which their further employment became expensive or troublesome. The State had often legislated in the interests of children apprenticed to brutal masters, and it would seem that the drafters of the Act of 1802 had in mind little more than a special case of this class. We read in the preamble "whereas it hath of late become a practice in cotton and woollen mills . . . to employ a great number of male and female apprentices, and other persons, in the same buildings, in consequence of which certain regulations are become necessary to preserve the health and morals of such apprentices," and the main tenor of the Act is to secure from the masters satisfactory clothing, housing, and education for the children. It is probable that as early as 1802 a formal apprenticeship contract was only entered into in some cases. As time went on it seems to have become exceptional. The pretence of teaching the children a trade would be dropped all the more readily as legislation had singled ont apprentices for protection, and left unapprenticed children ontside the law. And the growing population of Jancashire and the West Riding, together with the greater concentration of the factories which resulted from the use of steam power, rendered the masters increasingly independent of supplies of pauper apprentices from distant parishes.

The provisions of the law of 1802 were inadequate, and it applied to a riminishing proportion only, even of the children employed. Finally, its enforcement was left in the hands of the Justices of the Peace, and there is every reason to suppose that they neglected their diaty. It is at this point that the agitation with which kobert Owen's nam is connected began, and in 1819 an Act was passed which fixed a minimum age (nine years) for cmployment in the cotton industry, and a maximum day's work (12 hours, excluding the time reguired for meals) for all under the age of 16 . The Act of 1819 , rather than the Act of 1802 , deserves to be taken as the commenoment of the modern inelustrial cote. The fait accompli of chilul labour, as a normalelement in the industrial system, and as distinct from technical training in what will be the work of the adult, is acepted. This Act, like its predecessor, secms to late been normally crated, and a new agitation sprang up in the 
twenties whose objects were to amend and extend it and to secure better enforcement. With this movement the names of Oastler and Sadler are associated, and later that of Lord Shaftesbury. It culminated in the Act of 1833 which (1) applied to the textile industries generally, (2) prohibited work between 8.30 p.m. and $5.30 \mathrm{a} . \mathrm{m}$. and fixed a maximum day of 12 hours below the age of 18 , (3) reduced the maximum hours of work for children under 13 to 48 a week or nine in any one day, and (4) provided for the appointment of inspectors with considerable powers to enforce the regulations. From this time a continuous struggle went on which aimed at securing a maximum ten hours day for all young persons employed. This was won in 1847. In 1844 women were inchuded in the class protected, and a commencement was made with the legal enforcement of fencing for machinery. The first Mines Act had been passed in 1842 .

The advocates of this policy, in addition to the opposition of sinister interests had to meet two serious arguments, the first political, the second economic. What they proposed seemed likely prima facie to restrict individual liberty and to increase the cost of production. As regards the first point it does not seem that any serious advocate of laisser faire maintained either that children ought to be left to find protection in their own porer of resistance, or that it was an unjust interference with the liberty of the individual parent to restrict his right in the sale of his children's labour. But it was thought, and, as events showed, thonght rightly, that the legislation proposed, although technically its application might be restricted to children, young persons, and women, must in practice react upon the employment of adults, since in many cases the commercial working of the mills could not be carried on with adult male labour alone, even for a few hours at a time. The agitation thus presented itself as involving a limitation by the State of the right of the adult male to work as long as he chose, and as such was to many thinkers objectionable. The fact that the great majority of the adult males who would be affected favoured canclidates pledged to the restrictions, partly in the expectation that the restrictions on women and children would involve a reduction in their own hours of work, might have induced nearly everyone to waive the objection on the score of individual liberty had it not been reinforced by the economic objection. As it was, it seemed that 
the wage-carners were wrong in supposing that they would gain by a reduction of hours, and hence their willingness to allow their liberty to be restricted could be resisted on patemalistic grounds. There is this much excuse for the paternal Liberals, viz., that the argument by which many of the wage-earners justified their optimisn was thoroughly unsound. Robert Owen and one or two other experimentalists had shown that reduction in the hours of labour might be effected without reduction of output, and it might have been argned in any case that beyond a certain point additional leisure is more valuable than additional bread: but these arguments were less frequently used than the fallacy that reduction of the labour supply in the industries particularly affected would increase emplosment and raise wages; and as regards this argument the economists were doubtless right in maintaining that decline in the profits of these inclustries would gradually divert capital to other industries. In spite of misgivings, most of the economists supported the restriction of child labour. "Senior wrote against the acts when he had only just begun to study economics; a few years later he formally recanted his opinions. McCulloch has sometimes been quoted as an opponent of the acts. But in fact he heartily supported them; while Tooke was one of the sub-commissioners whose report on the employment of women and children in the mines roused public opinion to decisive action against it."'1

Another difficulty which the reformers had to face was their own lack (at least in many cases) of a reasoned theory of intervention. Nany of them accepted the general principle that adult males might be left to their own resources, a doctrine sufficiently ridiculous, in face of the facts of economic life and the views of the workmen themselves, and which further involved them in the paradox noter above of regulating the freedom of adults, de facto, whilst professing to confme their operations to women, young persons, and children. Worse than this in the eresof the aloused class, was the tendency to single out the inicpuities of a small section of employers whilst leaving montonched evils which had existed for centuries. "Why are we mill-owners," sail bright, " to be selected as subjects of interference?" and proceeded to point out that the percentage of accidents was far ligher amongst the carters in his employ, whom no one proposed to proted, than among the machine hands for

1 Marshall, " Principles of Eumomics," 1, 763, 11. 
whom he and his fellow employers were expected to "spend millions in boxing off our machinery." " lt is, of course, easy to reply to Bright that it is easier to "box" machinery than to "fence" horses. In any case a beginning must be made somewhere, and though, if he were living to-day, he would find less differential treatment to complain of, he would still find enough. But his frame of mind has a certain importance: it reminds us of the fact that the agitation was in part carried on as a war of revenge by the landed interest against the manufacturers. Lord Shaftesbury, again, was something of a prig if he was also a great humanitarian. If his dogged will secured success for the reformers, it must often have seemed likely that his lack of tact would involve them in defeat.

It does not form part of our plan to attempt a detailed study of modern collectivism in all its aspects. Many of them fall in whole, or in part, outside the field of economic history proper, and all of them are referable to the growth of the same opinions which have determined the trend of Poor Relief and Industrial Regulation. There is, of course, a constant reaction between the facts of modern economic structure and the development of ethical and social ideals. Iuch of modern municipal collectivism is due to the new conditions created by the growth of urban areas. But as observed in the case of factory legislation, principles of social action, which are originated to deal with new conditions, strike back upon older evils. Attempts to improve housing and sanitation in towns gradually work their way into villages just as the limitation of hours in factories fosters the demand for regulation of home work.

1 See Dicey, "Law and Cpinion in England," p. 235. 


\section{CHAPTER VI}

\section{THE LAW AND THE WAGE CONTTRACT}

BEFORE commencing our study of the beginnings of trade unionism it is clesirable to review briefly the point of development at which the law of wages had arrived by the middle of the eighteenth century, and the nature of the change of opinion on this matter which was going on in the minds of the ruling classes. The conception that the labourer, at least in the country districts, ought to give his services to any employer who desired them, on terms fixed by the State or its representatives, began to pass away in the serenteenth century, although the restrictions on settlement continued until the end of the eighteenth century to restrict the right of the labourer to sell his labour in the best market. Although the labour code of Elizabeth remained upon the statute book, imposing on the Justices of the Peace the duty of assessing reasonable wages, as time went on the industries not covered by the Statute of Artificers grew more numerous and important, whilst in those which were referred to specifically, the practice of assessment was gradually relaxed. It seems that even in the seventeenth century assessment by the Justices meant rather a formal indorsement of what were the customary rates of pay in a particular district than an impartial decision of what they orght to be. The practice, in fact, developed of leaving wages to be decided by contract between employer and workman long before the theory of assessment was abandoned by the State. No Gorernment, howerer, discarded the theory, or was unwilling to revive the old powers on occasion shown. In a series of cases the State interfered to check combined action on the part of employees, which aimed at raising wages, and late in the eighteenth century a veritable wages court was set on foot for the spitalfield silk weavers. Aleantime, the conception that economic relations were determined hy natural laws was coming to the front, and after the publication of "The Wealth of Nations" gained a rapid hold on erlucated minds. The idea that individual contracts are arbitrary arljustments, detemined hy one party or the other laving obtained for the moment the npper hand, was readily abandoned in favent of the view that wages and prices are determined 
within narrow limits by the action of indefeasible natural laws. It had been shown by Adam smith that price reactions, if allowed to take their natural course, tend in a competitive system to right themselves, the higher price attracting, the lower repelling, supply, and this reasoning was applied to the special case of wages without due consideration for the difference between labour and pork.

Thus, in the later decades of the eighteenth century two tendencies were at work on the rulers of the country-first, the remainder of class feeling, which taught them that the masses were turbulent children who must be kept in place, second, the developing grasp of an economic law of gravity, which might do society's work better if left alone than society could do it for itself through the instrument of government. Meantime the wage-earners held firm to their traditional view that though the law, as a whole, was dangerous it would sometimes protect them when their desires lay on the side of conservatism. Since they had neither read Adam Smith, nor realised the full meaning of the Industrial Revolution, their desires for the moment were distinctly conservative. They wanted the enforcement of the limitation of apprentices, or the prohibition of machinery - in a word, an industrial system which the revolution had relegated to the past. With the rise of the new cotton industry in the ninth decade of the eighteenth century, a period of working class agitation began which lasted for sixty years, and ultimately expired in the embers of Chartism. In one industry after another the workers reacted to the stimulus of change; sometimes the workers in many industries took the field together. In the course of this troubled period we can trace the rise of new weapons and a new policy, political agitation and trade unionism on the one hand, the determination to raise instead of merely to maintain the national standard of life on the other. In each case the lirect cause of the change was the Industrial Revolution. By concentrating the manufacturing population in towns and providing cheap and rapid transport facilities, it made organised action possible: by rapidly increasing the national power of production, it stamped the ideal of material progress into the very brain of the people.

The first stirrings of the labour movement in the concluding decades of the eighteenth century threw the governing classes off 
their balance. Nor is this surprising. The movement was violent and demanded an impracticable Conservatism. It may be that the policy into which Parliament drifted was partly determined by the fear that the horrors of the French Revolution miglat be repeated in England. But the Combination laws of 1799 and 1800 was a natural product of the state of mind described above. The Conservative instinct of keeping men in their places could well combine with a nascent belief in the beneficial action of the laws of supply and demand to cause Parliament to look with disfavour on combinations in restraint of wages. It needed only a little disorder and a little panic to translate this disfarour into a general prohibitory statute.

Until the Acts of 1799 and 1800 there had been no general enactment against combinations of wage-earners, although it had been forbidden specifically in a number of trades, and the common law condemned in general this as any other combination in restraint of trade. On the other hand, where a trade was regulated by the law of the land, combinations, which aimed at enforcing the law, were undoubtedly legal. The legislation of 1799 and 1800, combined with the law of conspiracy, made it criminal to join a trade union or organise a strike. Technically, combination of the employers was as illegal as combination of the men: in practice it seems to have been easy to convict the men, impossible to convict the masters. The situation thus created did not affect all trades in the same way. In highly skilled employments, which had a tradition of association reaching back into the eighteenth century, and which were not exposed to the disturbing influence of new machinery, the tradition of the trade was sufficient to preserve Trade Unionism, though donbtless the law materially checked its growth. In the rapidly expanding machine and factory industries of the Northern counties the law, whilst not festroying association, drove it underground. It tenderl to place the leadership, of the movement in the hands of those who felt least respect for law and order, and generally to make the men rely upon violence which conkl be organised rapidly, instearl of 1 prom persistent pressure, which requires the settled policy of a permanent association. It is hardly necessary to point out that these conditions make it much more difficult for the wageearning class in general to derelop by discussion and experiment a policy which took adequate account of the facts of the industrial 
situation. They were condemned to a series of temporary outbreaks of activity, the objects of which were conceived raguely and too often pursued by violent methods.

Meantime the sentiment in farour of individual liberty was steadlily growing under the influence of Bentham and his circle; men were becoming more conscious of the paradox that the Combination Act, which ostensibly provided for the free play of supply and demand in reference to the commodity labour, obtained this result by a wholesale restriction of the right of the individual to act as he thought best in his own interests. With the objects of trade-unionism, the individualists had no sympathy, and indeed. as has been seen, the arowed objects of the movement were often undesirable. In general, it seems to have escaped their notice that employers as well as wage-earners may resist the action of the law of supply and demand. The maximum wage which an employer could pay seemed to be definitely settled by the demand for the commodities produced, and it was held that he was prevented by the competition of other employers from ever paring less. The existing situation seemed, therefore, economically satisfactory. Politically it was unsatisfactory, for if, as the Benthamite believed, the individual is normally the best judge of his own interest, it must be right to allow wage-earners to combine, howerer desirable it might be to prevent them from compelling unwilling fellow-workers to join their unions. The line of argument indicated was followed out to its logical conclusions by Francis Place. Although, in his journeyman days; he had worked and suffered in the cause of combination, Place seems to have held firmly that trade unions, in the long run, could confer no benefit on their members. He retained, however, in his days of prosperity the wage-earner's point of view-the feeling of intolerable injustice which the grown man experiences when he is treated as a child and refused the right of adult manhood to burn his fingers in his own way. He had also a detailed knowledge of facts which enabled him to perceive the ill effects of proscribing the instinct of association. Finally he was a genuine individualist utilitarian, and believed that if men were left free to follow out what they supposed to be their interest, they would soon find out the points in which they were mistaken.

The change which was made in the law in 1824 was due to the activity of Place. He had carried on a press campaign against the 
Combination Act for ten years previously. He had interested the indispensable handful of Radical Members of Parliamentespecially Joseph Hume. Finally he directed their tactics at every point. The repeal of the Combination Act in 1824 was followed by an outburst of unionist activity in the North, whose leaders, in spite of the warnings of Place, showed the impracticable and violent temper which the state of the law up to that time had fostered. Parliament, which, in consequence of Place's tactics, had had before it a confused issue in 1824 (the Repeal of the Combination Acts had been tacked to other measures), now seemed inclined to consider the point separately, and there was considerable danger that the Government, under strong pressure from capitalist interests, would retrace its steps. In this crisis Place's mastery of tactics was again decisive. Though he conld not retain all that had been won in 1824 he secured a compromise, which enabled Trade Lnionism to develop, though it was far from effecting a completely satisfactory settlement. The Combination Act of 1800 remained repealed, but trade combination, were no longer exempted, as they had been in 1824, from the law of conspiracy; further, the right of discussion and agreement between masters and men was guaranteed bess fully in 1825 than in the previons year; lastly, the clauses which were intended to preclude intimidation and violence constituted, as interpreted by the Courts, a serious obstacke to collective action.

Between the legislation of $1824-5$ and the beginnings of the modern Trade Unionist movement, an interval of twenty years was filled with a general social movement, influenced partly by the ideas of Owen, partly by a doctrinaire Radical programme of political reform. The movement drew its strength from the idea of progress and the fact of misery, and though it ended in the fiasco of the Charter and the Naypole dance of optimistic free-traders, it carried the seeds of the chief social developments of the later Victorian period. In 1829-34 took place the Trades Union movement, distinguished from Trade Inionism by the fact that whilst the latter ains, primarily at least, at the organisation of labour trade by trade, the former amed at an immediate junction of the general labont power of the country, independently of the particular trade in which a given indiridual might earn his living. The ideas of Owen were behind the movement; its objective was a co-operative commonwealth; its plan of campaign was a general 
strike: a general strike pre-supposed establishment of a single Union for all the labour of the country. The National Union of Cotton Spinners (1829) prepared the way for the National Association for the Protection of Labour (1830) ; to this succeeded the Builders' or General Trades Union; and finally, early in 1834, a Grand National Consolidated Trades Union was established. In each case the rank and file of the movement consisted of individual wage-earners with individual grievances against individual employers; emotionally, they could react to the oratory of general ideals : intellectually, they were incapable of distinguishing between their own immediate interests and the ultimate interests of the cause. Hence it proved impossible to maintain discipline; affiliation went on rapidly, but the central executives had little control over the district Societies; long before general action was in sight the movement collapsed in a series of disconnected local strikes. The historical interest of the Trades Union movement is none the less great. More definitely than any other event it marks the transition of the wage-earning class from the conservative to the progressive ideal. It demonstrated also the power of wage-earners to combine over the greater part of the country ont of their own resources. More technically we notice the appearance of organisation in trades which hitherto had known little of mion. Textile workers, miners, potters, builders become the centre of gravity of unionism; the numerically small, high-skilled, non-machine trades are relatively less important. On the other hand the wage-eamers still, to some extent, look outside their own class for ideas and leadership. Their ultimate aim-so far as they have one-is supplied by Robert Owen; it is not ground out of their own experience. The terror which the movement inspired in the ruling classes was extreme. Especially alarming was the fact that agricultural labour was stirred. The sentence of seven years' imprisonment and transportation for administering a technically illegal oath was inflicted, not on machine hands in Lancashire but on agricultural labourers in a Southern county.

The failure of the Trades Union movement convinced the rageearners in the Northern counties that no considerable alteration in the structure of industry could be effected by combination. The policy of detailed improvement had not yet been developed. The remaining alternative was to seize the reins of Government. The

$20-(\mathbf{4} 498)$ 
control of Parliament through manhood suffrage has been the aim of at least a minority of popular leaders throughout the nineteenth century. Working class support for the reform movement, which produced the Act of 1832. was inspired by the ideal that a really popular government could recast the structure of industry. The Chartist movement of the 'forties was thus a natural product of disappointment at the narrow limits within which the suffrage had been expanded, and perception of the impracticability of Owenism. In the second half of the nineteenth century we trace first an atomistic period lasting into the eighties; the demand for political power was not abandoned. but the object aimed at was rather the removal of what were considered to be special disabilities of the working class, or some section of it, than a conscious and deliberate reconstruction of society. Only in the last twenty-five years has the latter conception re-emerged-in a form, of course, which differs materially from that which it assumed in the earlier part of the century.

There were three chief causes of this interruption, of roughly forty years (1848-85), in the natural development of working class aims. First, the débâcle of Owenism and Chartism discredited Utopian schemes and heroic remedies. Second, the individualist philosophy of the eighteenth century filtered down to the masses just at the period when it was beginning to lose its hold upon educated thought. Third, the development of practical policies and machinery by a number of growing mions and by the co-operative stores absorbed attention.

A "New Model" of Trade Lnionism grew up between 1843 and 1860 in a number of important industries-building, engineering, nining, and cotton may be specified. Its characteristics were the acrumulation of large funds which might be employed cither for general benefit purposes or in case of need as strike pay, the cmployment of a permanent, salaried executive to advise and carry out its policy, concentration of attention in the case of each union on the interests of the particular trade in which it was formed, and the absence of interest quà union in any social problem which latel not a direet bearing on the wage contrate in the trade concerned. The policy developer hy these bodies differed from that which had ben pursted by their prederessom in that it was derived from detailed experience of the several industries. Their leaders ceased 
to advocate either impracticable conservatism or nehulous proposals for a complete transformation of industry ; they accepted the facts of the situation, and strove to handle and turn them to the interest of the wage-earners. It will be convenient at this point to turn back and describe, in more detail, the aims of the primitive unions in the earlier decades of the century before the movement had passed under the control of Owenism; the later policy will then appear in its true historical perspective as a modification of this primitive type induced by change of circumstances and increase of knowledge.

Before the Industrial Revolution combination among wageearners was the rule rather than the exception: ${ }^{1}$ it was, however, usually spasmodic and narrowly local. The growth of the factory system certainly intensified many of the evils which unionism resists, but a more important part in promoting unionism was played by the industrial changes which massed the workers in towns and made communication rapid and cheap. ${ }^{2}$

Primitive unionism in the early decades of the nineteenth century had one more or less conscious policy - that of preserving a traditional standard of living; and two methods of obtaining this endhostility to machinery and demand for limitation of entrance to the trade. Arkwright, and many others who sought to introduce improved machinery, saw their property destroyed by riots, and went at times in danger of their lives. From time to time, as in the case described in "Shirley," the agitation became indistinguishable from civil war. Manufacturers barricaded their mills and repelled the mob with firearms, or saw them burnt and their machinery broken. Uttermost intimidation of unpopular masters, foremen, or blacklegs, was employed, and occasionally they were murdered; vitriol throwing was not unknown. The fight against machinery was throughout a lost cause, and the Government decided against continuing the Elizabethan policy of restricting entrance to trades. Hence, by the middle of the century it had become clear to the new leaders that the new conditions of industry made it impossible for the wage-earners to obtain, in its full simplicity, the conservative system, which had been the instinctive substance of

1 Cf. Adam Smith, "Wealth of Nations," I, YIII.

2 The growth of unionism is as remarkable in certain trades, e.g., building, whose techuique has hardly altered, as in the factory inclustries proper. 
their demands. The problem was-How much could be conceded compatibly with a tolerable manner of life for the wage-earner, and how much could he extracted from the employers? The answer to these questions falls properly into two halves. In the first place it was posible to remedy. by collective action, an immense amount of individual hard-hip and ill-usage. Secondly. something might conceivably be effected in mitigation of such general uphearals of the stanclard of life as had hitherto been occasioned by economic progress.

When the representative of a number of workers enters into negotiations with an employer, he is evidently in a stronger position than almost any one among their number can be. To begin with, he is a trained bargainer, and can have at least a considerable knowledge of the general state of trade. and of the labour market. Secondly. he has at his back a reserve of numbers and money, which often cnables him to intimiclate at least an evil doer. Again, any collective bargain. even if concluded by an unskilful man, is so far more satisfactory than the individual system as that it prevents an employer from taking advantage of the exceptional position of some of his men. When the bargain is struck between representatives of a union and representatives of a number of employers the position is still further improved. for it becomes possible to level conditions throughout the whole of an industry. In the same way the complaints of an individual are more likely to be redressed when presented through a responsible official than when urged in person. These brief indications explain one considerable side of the policy dereloped by the new unions after 1850 . The effort is to secure recognition for the official of the union, and to establish the fom lations of collective bargaining and collective demand for redress of individual injury. Details of policy differ, of course, in different industries - in some a detailed list of piece rates is established, in others minimum (never maximum) time rates, and so) on.

But this is only one side of the policy. It seeks to put the men in a prosition to secure the highest wages and best conditions which can be enforeed at any particular moment, and to prevent individual oppression. The other side, viz, that which seeks to control the growth and development of the inchistry in the interests of the wage-earners remains to be considered. This may be summed 
up as follows. The old ideal of a conservative standard of life is modified by the conception of progress. The determination not to allow wages to fall is maintained, but the hope is to make them rise; and the admission of this hope involves the adinission that industrial progress may benefit the wage-earner. Evidently. if the methods of industry stand still wages cannot rise greatly; the tendency was, therefore, for the new unions, as they increased in strength, to change their attitude towards entrance to the trade and increased use of machinery, and to seek to control rather than altogether to resist change. As regards machinery, the policy developed was to prevent new types being introduced so rapidly as to depreciate unduly the value of acquired skill, and to secure for the workers, in the shape of increased wages, some part of the economy of improvements. As regards limitation of numbers, although a consistently narrow policy was maintained by a few unions whose strategical position was abnormally strong, the more general tendency was to resist only such a considerable influx of low-paid labour as would serionsly endanger the policy of a rising standard of life. It is impossible to maintain that even at the end of the century unionism was in no case shortsightedly or selfishly opposed to industrial progress. It is hardly necessary to point out that inasmuch as the whole question is one of compromise it is inevitable that precisely the right compromise will not always be attained. But no collection of specific instances of resistance to mechanical improvement or restriction of entrance to a trade gives adequate ground for a generally adverse verdict on trade union policy. The harm done by refusal to use an improved machine can be seen and weighed precisely ; the evil of over-rapid modification of the demand for labour is less ponderable but equally real. It is more fruitful to insist on the advantage of agreements between organisers and wage-earners, which aim at providing for the gradual introduction of new processes. than to suggest that the very real problems involved can be summarily dismissed by instancing the inevitability and general advantage of economic progress.

Although, as has been seen, Trade Unionism remained primarily sectional in its development between 1840 and 1885 , the begimnings of the common aims and action. which have been a chief feature of the last twenty years, can be traced far back into the individualist 
period. As early as the 'fifties the executive leaders of a number of important unions were living in London in close touch with one another, and between 1858 and 1867 permanent Trades Councils arose in the principal towns. The first representative conference was held in London in 1864. To this period belongs the agitation directed towards placing employers and workmen on an equal footing before the law. As the law stood breach of contract on the part of an employer was a civil offence, to be met by an action for damages: on the part of a wage-earner it was a crime, punishable by fine or imprisonment. Criminal procedure did not permit examination of the accused; hence where an employer accused a wage-earner the evidence of the former was the only evidence to which the court could listen, if the contract had not been conchuded before witnesses. It was also necessary that the general legal position of Trade Unionism should be reconsidered. In 1866 a case of violence against a blackleg, at Sheffield, aroused considerable sentiment against the movement, and a Commission of Enquiry was appointed. In the next year the Boiler-makers failed to recover a sum of money embezzled by one of their officials. and the Court of Queen's Bench decided that the Union had no legal status on which it could sue or be sued. Further, the compromise of 1825, as interpreted by subsequent judicial decisions, was no longer tenable. llectings and agreements in respect of wages and hours of labour had been expressly legalised, but a Trade Union which acted "in restraint of trade," was still an " illegal conspiracy," and its members liable to criminal penalties.

Contrary to expectation, the Commission of 1867 was convinced by evidenee that the action of Trade Unionism had been, in many cases, neither mureasonable nor detrimental to society. It seemed ratluer that the business of the legislature was to revise its legal position, and to give it considerable frecom of action. Nevertheless, the legislation passed in 1871 was still largely actuated by hostility to combinations. The Trade Lnion Act declared that a Trade Union did not become a criminal or illegal association merely becanse it acted in restraint of trade, but the Criminal Law Amendment Act, which proported merely to repress intimidation and violence, Was drawn in such wide terms as to leave it doubtful whether the most peaceful forms of picketing were noncriminal. The position of the mions was thus worse rather than 
better than it had been before, and their anger was one cause of the defeat of the Liberals in 1874. In 1875 and 1876 laws were passed which gave, in substance, what was demanded by the mions. The Criminal Law Amendment Act of 1871 was repealed. The Conspiracy and Protection of Property Act defined reasonably the limits of criminal conspiracy in trade disputes. The Employers and Workmen Act placed employer and employee on an equal footing before the law. Peaceful picketing was legalised, whilst no form of coercion any longer involved criminal penalties on a unionist unless the act itself was criminal when committed by any individual.

Temporary protection for the funds of Trade Unions against dishonest officials had been granted in 1869, and the Acts of 1870 and 1876 put this matter on a firm basis. In order to do this it was necessary to give to Trade Unions some sort of legal existence which could be recognised by the courts. This was effected by allowing Trade Unions as registered societies to sue defaulting officials. At the same time the Act did not enable the courts to entertain any legal proceedings arising out of an alleged breach of contract between a Trade Union and its nembers. Neither Act was intended to enable a union to sue and be sued in general : but it was only expressly relieved from a certain class of liabilities in this respect; at the time, and for long afterwards, it was supposed that the protection granted went further: but this view was upset by decisions of the Courts at the end of the century; in 1901 it was held by the House of Lords that a Trade Union conld be sued in its registered name, and that the funds of an unregistered union could be made liable by a representative action. Meantime the courts had developed a definition of picketing, which made it illegal for a representative of the union to meet or call upon a wage-eamer, if his object was to coerce not the wage-earner himself but his employer ; furthermore, it had been held that although " an agreement ... to do ... any act in furtherance of a trade dispute between employers and workmen" was not "indictable as a conspiracy if such act committed by one person would not be punishable as a crime," it might be so indictable if the employer used non-union labour exclusively, or if the members of the union in question were not employed by the employer attacked ; lastly, under the civil law, unions were liable to an indeterminate extent for damage to 
employers or others arising out of their actions, however lawful those actions might be in themselves.

The effects of the Act of 1906 are thus summed up by Prof. Chapman: "It declares that an act " lone in contemplation or furtherance of a trade dispute,' is not rendered actionable merely by its being 'done in pursuance of an agreement or combination by two or more persons'; and lays it down that 'an act done by a person in contemplation or furtherance of a trade lispute shall not be actionable on the ground only that it induces some other person to break a contract of employment, or that it is an interference with the trade, business, or employment of some other person or with the right of some other person to dispose of his capital or his labour as he wills.' It legalises picketing to obtain or communicate information, or peacefully to persuade any person to work or abstain from working; it sets asile the Taff Vale judgment by enacting that trade unions shall not be suable; and declares that in this Act and in the Conspiracy and Protection of Property Act, 1875, the expressions 'trade dispute' and 'workmen' shall be understood in the widest sense." 1

The dominant thought of unionism between 1845 and 1885 was individualist. It was held that if the law could be so adjusted as to permit the free exercise of the right of collective bargaining no positive interference by the State with the wages contract would be desirable. In the eighties a new spirit became eviclent, which has since, upon the whole, tended to approximate the policy of unionism to a systematic socialism, although there are, of course, still many individualists in the ranks of the movement, and a still greater number of men whose ideal of State organisation is exceedingly vague. In this last phase of the movenent the following points may be emphasised. First, a dereloping capacity of the labour movement to dispense with the stimulus of midelle-class ideas. Though the influence of Marx. Hemry ceorge, and the Fabians is not negligible. it is small in comparison with that of Robert Owen in the thirties. of eren of the Christian Sorialists at a later date. secondly, the machinery of mionism has shown signs of extending from skilled to unskilled halumr. (ither by the opening of existing unions to inchude lower grates of wage-arners, or by the independent organisation of stoch cantral trarkes as dock labourers and match-girls.

\footnotetext{
I Brasoly and Choman, "Work and Wages," II, 70.
} 
Thirdly, both locally and in the country as a whole, common action on the part of distinct unions has become more important. and the movement for the capture by "labour" of local and central government has grown rapidly. A federation of Trade Cnions has existed since 1899. whose membership is about 600.000 , a third of the organised labour of the country. and many unions contribute to finance members of Parliament.

Down to the great Parliamentary struggle between 1867 and 1876 , the opinion of employers in almost all industries was intensely hostile to collective bargaining. There were few who recognised a moral right of combination. Still fewer who believed that the exercise of the right was in the true interest of their employees, and a mere handful who saw in it a socially beneficent force. In the last thirty years a considerable change has occurred. In most industries, where the system has been long established, a large minority of employers hold all the views indicated above, and a certain percentage maintain that unionism, in the long run, promotes the interest even of the employer. Especially in large scale business many employers find in the organisation of their wageearners a useful check upon the integrity of their foremen and departmental nanagers, and a conveniently impersonal way of bringing pressure to bear on dishonest or idle wage-earners. Further, the employer who relies for his profits upon skill in organising his business, and marketing his output, is protected by the existence of a union against the competition of those who, whilst inferior to himself in these respects, excel him in the will or power to beat down the standard conditions and wages of the trade. Above all, the existence of a strong organisation makes it possible in a great measure to settle the general terms upon which labour shall be employed for long periods. The employer is set free from the risk of constant minor stoppages and disputes, and can concentrate his attention for months, or even years, at a time on other problems.

The development of the machinery of Conciliation and Arbitration during the past forty years has been very rapid. It is impossible to insert here any detailed account either of the various types which have emerged, or of the stages of the growth of the system, but a few words may be added. Early in the nineteenth century standard lists of wages appear in some branches of the textile industry: these, however, were seldom, if ever, the result of 
agreement between employers and employees; usually they were a product of the impossibility for an employer of several humdred, or even thousand, men to arrange an individual bargain with each. In the last fifty years such "lists" have become a normal feature in those of the staple industries which adopt the piecerork system, and are usually the product of elaborate negotiations between representatives of the two parties concerned, who agree to observe the settlement arrived at for a period which may or may not be indefinite. They are based upon the idea of so defining the piece-rate for each kind of machine that a normally efficient worker will be able to earn a standard wage. In industries where the piece-rate system is either impracticable (in consequence of the lack of persistent types of work) or is objected to by employers or employees, the usual course is to define directly the minimum wages payable in different grades. Either plan may be, and occasionally has been, associated with the device of the sliding scaleit being provided that the standard rates should vary in predetermined accorlance with alterations in the price of the commodity produced or one of its main constituents. The negotiations which lead up to these or other agreements, touching the terms and conditions of employment, are often presided over by a benevolent neutral whose business is to smooth difficulties, preserve an inoffensive tone in the discussion, and in case of divergence suggest possible compromises. Nore rarely differences are submitted to the judgment of an arbitrator, whose decisions each side binds itself beforehand to accept; and a frequent feature of general agreements reacheel muder " conciliation " is the inchusion of a clause consigning to arbitration any differences on points of detail which may arise ont of the agreenent. In 1896 a Conciliation Act gave the Board of Tracle the right of conciliatory mediation in a trade dispute, and empowered it to appoint a Board of Arbitration in response to a joint request from the employers and wage-earners. In 1907 the intervention of the Board of Trade in the Raihway dispute resulted in the establishment of an elaborate system of arbitration boards to determine the conditions of employment in that industry.

The complexity of the problem of collective bargaining varies cnormonsly with the conditions of particular industries. Where, as in the cotton industry, an chaborate piece-list is practicable, the bargain can control in letail the remmeration of men whose 
individual efficiency varies infinitely. In the engineering trade, on the other hand, and again in building, piece lists are resisted by the unions. It is contended that the difference in detail between each piece of work and the next would leave the piece-worker dependent in great measure upon the good faith of his employer. It is plain that where a union insists on fixing minimum time-rates and resists the piece-rate system, the more efficient men must depend on their own bargaining power for securing higher pay or more satisfactory conditions proportionate to the extra value of their work. As the bargaining power of the individual is not always sufficient, there is more room in such a trade for a tradition to develop, which encourages the stronger individual to restrict his output to the maximum which is attainable by the least efficient of those who are employed. He has not that certainty of obtaining extra pay for extra value rendered, which night blind him to the allegect interest of the trade as a whole in minimising ontput. Further objection to improved machinery is more likely to be active where payment is made by time. In the piece-work system the operative stands to gain prima facie by the speeding up, and improvement of machinery, in so far as his work does not become actually harder. If he is paid by time, on the other hand, the whole advantage of the improved process accrues to the employer, even though it may impose a greater strain on the worker, until a readjustment of rates has taken place. For these reasons complaints of unionism are on the whole more common among employers in industries where time-rates prevail than in those where piece-rates are the rule. Where, as in the building trades, we find combined a union policy of time-rates, the absence of foreign competition, and a rapid expansion of the industry, the complaints are at their maximum. 


\section{CHAPTER VII}

\section{MONEY, CREDIT, AND FLUCTUATIONS}

Derixg the eighteenth century gold became the chicf means of effecting considerable parments, in so far as it was not already supplanted by credit instruments. Even after the change of 1717 it was slightly overrated as compared with silver; the latter came gradually to be used only for small payments; and it was difficult to retain enough in circulation even for this purpose. Both gold and silver coins were much depreciated by wear and fraud, but silver being rated too low, its condition was worse than that of gold. In 1756 , however, the value of gold as in silver began to rise throughout Europe, and by 1771 this movement had gone so far that the gold comage was becoming deficient. "Quantities of old silver coin . . . or coin purporting to be such, greatly below the standard of the Mint in weight," were imported and guineas exported in exchange. A remedy was devised in 1774; the gold was called in and re-issued at the old standard, the legal tender of silver com by tale was restricted to f25. Silver remained. however. legal tender by weight 11 , to any amount at the rate of 5. 2d. an oz. until the Act of 1816. which made silver coins tokens, restricted their legal tender capacity to 405 . and definitely established gold as the sole standard of value in the country. The decision in favour of monometallism was determined by considerations which have little to do with the modern bimetallic controversy. The problem of the eighteenth century, as of earlier times, was to secure a satisfartory medium of exchange or currency, and the gradual elatoration of a token coinage was an important step in this direction. Morken binctallists are concerned with a different problem, viz., that of providing a satisfitctory standard of value, and it is obvious that the use of silver as the material of a token coinage is quite compatible with its use as one timb of a double standard. Fold momometallism was, however, a natural hy-product of the reduction of silver coins to the rank of tokens. The economy of practical statesmanship led the comtry into that path which seemed to involve a minimum of change. The suspemsion of cash payments by the Bank of England in 1797 and the subseguent depreciation of their notes 
had driven all gold and much silver out of circulation. For large payments this was of little moment since bank paper could be substituted for gold. For retail trade and wage payments it was an enormous inconvenience. Throughout the country traders and employers issued unathorised token currencies, a development which no doubt facilitated, if it did not actually suggest, the issue of token coins by the central government.

The supersession of standard money by token coins, as a medium of petty exchanges, is one side of a general movement during the last century and a half towards a separation of the function of exchange medium from the function of standard of value. What has been done for small exchanges by the invention of token coins has been done for large exchanges by the derelopment of banking credit. In both cases we find exchanges effected by instruments or machinery which make it unnecessary to retain in circulation a volume of metal equal in intrinsic value to the exchanges which it effects at any moment. The identity between the two sides of this movement is obscured in two ways. Firstly, whereas the issue of token coins has been retained in the hands of the State, the management of banking currency remains in the hands of the private enterprises which have built it up. Secondly, whilst the economy effected by our token currency is comparatively small, ${ }^{1}$ the economy effected by our banking currency is exceedingly, and some think dangerously. great.

The use of bank credit as a substitute for money was little developed before the Industrial Revolution. In 1750 there were only twelve bankers' shops in England outside London, and even in London there was room for much expansion. The last forty years of the eighteenth century witnessed an extraordinarily rapid growth of banking both in London and in the provinces. Unfortunately much of this growth was financially unsound. The conditions created by the sudden development of large scale production and the increase of trade throughout the country would probably have entailed, in any event, excessive use of credit: and apart from the industrial and commercial factors, the alternation of war and peace promoted instability. It is, however, clear that the evil which such causes can produce is determined within wide limits by the

${ }^{1}$ Silver coins will purchase only about twice the value of the quantity of silver which they contain. 
organisation and technique of banking in any given country, and it must be recognised that in England, at the close of the eighteenth century, both were defective. As regards organisation, the monopoly conferred upon the Bank of England early in the century prevented the formation of companies on the Scotch system to meet the demand for bank credit. Private banking has, of course, some obrious advantages as compared with corporate banking, and a number of the firms which arose in England were excellently managed. The majority, however, were not; and riewing the matter broadly it is regrettable that banking in England did not take, from the outset, the form to which it has since gravitated-viz., that of a small number of powerful corporations, each controlling a number of branches. ${ }^{1}$ As things were. "multitudes of miserable shopkeepers in the country, grocers, tailors, drapers, started up like mushrooms and turned bankers, and issued their notes, inmdating the country with their miserable rags. Burke says that when he came to England, in 1750 , there were not twelve bankers out of London; in 1793 there were nearly $400 ., 2$

As regards technique there is not much interest in discussing the management of these private firms. That of the Bank of England, however, is of the first importance in view of the central position held by that institution. The management of the Bank of England has at no period in its history been other than conscientions. The manner in which its directorate is chosen from the business world, its tradition of service to the State, and representation of solid interests, have preserved it from some of the dangers to which a merely profit-making concern is exposed. It is, in fact, and has been almost from the first, informally a national institution, if formally a trading company. At the time of the Industrial Revolution it fully recognised certain unexpressed obligations towards the public. Its business was to support the Government, and to assist trade ; but not to go out of its way in search of extra profits. At normal times its solid conservatism kept it pretty straight. It discounted only "sonnd commereial paper," and that at tolerably high rates 4 to 5 fere cent. If the market rate fell lenew this it diel not alter its rate.

1 That this develupment was techuically pussible in England secms clear from Sontch experience.

" Mackend, "Theory and Practice of Binking," I, 436. 
but allowed its discount business to fall off : thus the rates which it regularly maintained were high enough to correct automatically any ordinary movement of the exchanges against the country. The directorate had, however, no clear perception of the relation between the rates at which money could be borrowed and the state of the exchanges. If the exchanges turned so much against the country as to drain their reserve of bullion dangerously low they, of course, restricted their discounts. They did so, however, merely as a matter of self-protection-to escape bankiruptcy. If their policy turned the exchanges in farour of England, they congratulated themselves on having ridden out the storm safely, without perceiving that their own action had assisted the national recovery. There were, of course. a few men who had more or less clearly worked out the connection between discounting and the state of the exchanges. In their view restriction of discounts meant a reduction of the quantity of money in the channels of circulation. Diminished money caused prices to fall. The fall of prices increased exports. The increase of exports restored the exchanges. This line of argument reached correct conclusions by unjustifiably short cuts, and as it ignored the technical complexities of the subject it carried little weight with the business world. ${ }^{1}$

The defective theory of the directors of the Bank of England mattered comparatively little so long as the legal framework within which banking operations had developed remained substantially unaltered. As long as it was necessary for the Bank of England to meet its liabilities in gold, a drain of gold compelled it to restrict its discounts-compelled it, that is, to set in motion unconsciously forces which operated so as to check the drain. Even so it was inherently probable, and it did in fact so turn out, that the Bank would postpone restriction dangerously long. Conceiving that the foreign exchanges were controlled by forces entirely independent of its own action, and realising the hardship inflicted upon clients by the refusal of accommodation, it would be apt to go on hoping that a favourable turn in the exchanges would relieve it of the disagreeable necessity of protecting its reserves. The situation

${ }^{1}$ It acquired later consiclerable prestige, however, because predictions founded upon it turned out to be correct. As restated by modern writers. the quantity theory of money is s, complicated and cumbrous, that it is inferior, even pedagogically, to a direct assault on the technical difficulties which it evarles. 
was altered entirely in 1797. when the Bank was ordered by the Government to suspend cash payments. Relieved now of any anxiety about its reserves it could perform what it conceived to be its duty of dispensing at rates not above 5 per cent. as much accommodation as trade demanded. This. of course, was no very serious matter so long as no exceptionally serious derangement of commerce occurred, for a $\mathbf{5}$ per cent. rate is (and was) so high that only under exceptional circumstances are excessive issnes under it probable. And, in fact, the depreciation of the Bank note during the period of suspension (1797-1819) was never serions, judged by the standard of political issues of inconvertible paper money. It was, however, serions enongh. Commencing in $1800,{ }^{1}$ it became really serious in the winter of 1808-9. A mania of speculation had arisen as the result of the opening up of English trade with the Portuguese possessions in South America. The conservative finance of the Bank of England gave way in the general excitement. "It is stated by Sir Irancis Baring, in his evidence before the Bullion Committee, that since the restriction he knew of many instances of clerks, not worth $f 100$, who had started as merchants, and had been allowed to lave discount accounts of from $f 5,000$ to f10,000... The paper discounted by the Bank, which had been $f 2,946,500$ in 1795 , rose to $f 15,475,700$ in 1809 , and to $820,070,600$ in 1810 ." ' The paper price of standard gold was quoted at ft 10s. in Iay, 1809, and continued to rise. Early in 1810 the House of Commons appointed the famous committee of inquiry into " the high price of gold bullion."

The $r_{1}$,rt of this committee was undonbtedly a fine piece of work, but it did not cover the whole field as completely as has been maintained by some of its admirers. Its members were, to some extent, at cross purposes with the directors of the Bank who gave evidence, and neither appreciated nor cleared up certain practical difficulties which trombled the latter. They showed clearly enough that the rise in the paper price of gold bullion was due to excessive issues by the liank in the sense that the price cotth not have risen harl those issues been restricted. The directors of the Bank

1 A deficient harvest in 1799, and had prospects for 1800 , caused an umusual importation of wheat, and lublion was also draned to flamburg by the rexistence there of abmormally high discount rates the result of a crisis in 1799 .

2 Macleod, "Theory and Practice of Banking," II, 25. 
maintained, on the other hand, that the Bank could not be said to have issued an excessive quantity of notes since so far from forcing notes upon the public they had adhered carefully to their traditional practice of issuing only as many as were required for the purposes of trade. ${ }^{1}$ It is plain that the two partics had in their minds quite different criteria of excess. To the committee it meant such a quantity of notes as would cause their value to depreciate; to the directors it meant more notes than were required by legitimate commerce. It is further plain that the criterion of the Committee was at least far nearer the truth than that of the directors. The failure of the committee lay in its inability to realise the full value of the practical consideration which made the directors obstinate for their view. This practical consideration was as follows: restriction of issue, as understood and practised by the Bank, meant not a simple alteration of the rate of cliscount to a higher figure, as is the modern practice, but the refusal to lend to their clients on any terms at all. On December 31st, 1795, the following notice was posted in the discount office :-

"Pursuant to an order of the Court of Directors, notice is hereby given that no Bills will be taken in for discounts at this office after 12 o'clock noon or Notes after 12 o'clock on Wednesdays; that in future whenever the Bills sent in for discount shall in any day amount to a larger sum than it shall be resolved to discount on that day a pro rata proportion of such Bills in each parcel as are not otherwise objectionable will be returned to the person sending in the same without regard to the respectability of the party sending in the Bills or the solidity of the Bills themselves."

It is evident that such a measure might entail wide ruin in a monetary crisis. The device of a high discount rate autonatically sifts out the traders who must have assistance at any price from those who can afford to wait, and further, of course, induces the individual to minimise his demands. The system practised at the close of the eighteenth century was too liberal to those who could afford to wait and not liberal enough to those who could not. The evil which it entailed was clear enough to the directors, and they probably felt that it was greater than the evil entailed by

1 The evidence of Mr. Baring, quoted above, seems to show that the rirectors in maintaining this exaggerated somewhat the actual extent of their conservatism.

$2 \mathrm{I}-\left(\mathrm{I}_{49} \mathrm{8}\right)$ 
suspension of cash payments. Restriction of discounts. they would maintain, might be all very well in theory; in practice it was fatal. and their minds would be hemetically closed against all reasoning which seemed to lead up to that fatal conclusion. The reason of this system of restricting discounts was, of course, the existence of a usury law, which limited the rate of interest to a maximum of $\mathbf{5}$ per cent. The Bank. from the outset, had prided itself on refraining from the usurious practices of private moneylenders. It does not seem to have occurred to its directorate that a change of system in this respect would rob restriction of half its terrors, nor did it occur apparently to the committee either. Each party stood firmly by that theory of issues which led to the practical conclusion which it thought of most importance. The situation was so far altered by 1819 that the evils of inconvertible paper were much more clearly realised, and a scheme for resumption was carried through Parliament. But the essential point that the Bank should be authorised and instructed to manipulate its discounts by raising the rate of interest was still neglected. It was not till 1833 that the Bank was authorised to raise its rate above 5 per cent., and more years elapsed before it made this expedient part of its normal policy. The gold drain of 1855 was the first which the Bank resisted with promptitude and decision.

In the period 1797 to 1819 , when there was no gold in circulation, attention was naturally turned to the superiority, in some respects, of a paper currency. Ricardo elaborated a scheme by which, whilst one of the precious metals might be retained as the standard of value. the country. by the use of paper, might save almost the whole cost of an intrinsically valuable medium of exchange. His plan was that the Bank of England should issue notes. and hold against them a reserve of bullion from which what was required for export might be withdrawn. His prosposal to some extent anticipated suggestions which have been male in the last twenty vears for the insue of $\mathrm{fl}$ notes. He went. however. much farther-desiring to see no standard mon'y at all in circulation -and the object which he proposed was to economise the rapital of the country and not to strengthen the reserve of the credit sistem.

For such a scheme opinion was not prepared. The average man

1 The dificulty of preventing forgery was also an whjection. 
had seen the evils of an unskilfully managed paper currency and demanded tangible gold. A considerable body of opinion, however, demanded that the resumption of cash payments should be effected by reducing the quantity of gold contained in a legal pound instead of raising the gold value of the depreciated paper. Their arguments were that such a restriction as wonld remove the premium on gold would hamper trade intolerably, and that as contraçts had adjusted themselves to the high prices caused by inflation, more injustice would be done by taking measures which must reduce prices than by altering the standard. The controversy was substantially the same as that between Lowndes and Locke at the close of the seventeenth century: the adrocates of "sound" money-i.e., the creditor and proprietary classesagain won the day.

The resumption of cash payments did not bring with it any immediate remedy of the fundamental faults of the English banking system. The defective organisation of banking in the hands of weak private banks remained; the defective technique of the Bank of England in the management of its note issues remained also. A period of experimental legislation had, however, commenced and continued until the Act of 1844. In this legislation two distinct lines may be traced, the gradual breach in the Bank of England's monopoly of joint-stock banking, and the growing restriction of the right of note issue.

The disasters of English banking between 1790 and 1820 had been very slightly reflected in Scotland, and it was only natural therefore, that opinion farourable to the Scotch system of joint stock banks and branches should gain ground. In 1823 a pamphlet was published by Mr. Joplin in which it was maintained that the privilege of the Bank of England only prechuded the formation of joint stock banks of issue, and did not bar corporations which restricted themselves to deposit banking. This discovery was not of much importance when it was made, for although the deposit and cheque system was already developing in London, the note was still the principal credit instrument in the country. A renewal of disasters amongst the private bankers, in 1824-5, brought opinion to a head, and the Government determined to enlarge in some way the freedom of corporate banking. Nothing could be done however, without the assent of the Bank of England in view of the 
fact that its privileges did not expire until 1832: and the Bank whilst apparently making considerable concessions, really retained the kernel of its monopoly. The Act of 1826 permitted the establishment of joint stock banks of issue, provided that they had no branches in London or within a sixty-five mile radius of London. As the financial business of the country was focussed at the metropolis, the Act precluded a really satisfactory experiment upon Scotch lines. The Act of 1833 , on the other hand, which revised the privileges of the Bank of England, merely asserted the legality of the view put forward by Joplin ten years earlier, that joint stock banks might operate in London provided they did not issue notes. The establishment of the London and Westminster Bank ensued quickly. It was followed by the London Joint Stock Bank in 1836, the Lnion Bank and the London and County Bank in 1839, and others. It is clear that neither of these Acts made possible a strong experiment in imitation of the Scotch system: but it is probable that in any case banking organisation had gone too far on a line of its own in England for such an experiment to succeed. But the ill success of provincial joint stock banks, between 1826 and 1840 , undoubtedly contributed unduly to the trimmph of that body of opinion which favoured drastic control of note issues. It could be suggested (although it was not really the case) that every possible expedient, sliort of restriction, had been tried and had failed.

The evils of the suspension period had left in men's minds a more or less definite feeling against a paper circulation. The events of the next twenty years-1819-1839-led men to conclude that whatever was possible in Scotland, the English nation required a substantial gold basis to its credit system. The policy embodying this conclusion, which gradually shaped itself, had two sides. On the one hand steps were taken to insure a substantial circulation of gold: on the other to insme that all note issues should have a grood gold lacking.

The first of these oljects was attained by a provision in the Act of 1826, which prohibited the issue of notes for smaller sums than 5.5 . The attempt of the Government to extend this measure to Scotland was defeated, ' but an Art in 1828 prohilited the circulation of Serteh notes in England. As regards the desirability of maintaining

1 'he: comnter-agitation was led by Sir Walter Soott, writing under the psentonym of Malachi Malagrowther. 
a gold circulation for small exchanges, there was not much difference of opinion in spite of the authority of Ricardo. There was an altogether unreasoning hope that the gold thus retained in the conntry wonld somehow maintain confidence in commercial crises. ${ }^{1}$ It was also felt that it would serve as a potential reserve against military requirements in time of war. In regard to the second point-restriction of issues-controversy was hotly carried on for many years by advocates of the "banking " and the "currency" principles respectively. These schools were the intellectual heirs of the directors and the committee in 1810.

The former had so far shifted from the ground which was taken up by their prototypes in 1810 that they accepted convertibility as the test of issue. Thcir overt contention was that as long as a bank's notes are convertible over-issue is impossible, since any commencement of it will be nipped in the bud by some of the notes being returned for conversion. With this statement no one need quarrel, but it did not, of course, meet in the least the contention of their opponents that the right of issue required to be regulated in order to prevent banks from issuing notes in quantities which they would be unable to convert. When they faced this point the advocates of the "banking " principle fell back upon the doctrine of the directors in 1810 , viz., that the amount of issue is determined by the requirements of trade, and that it is the business of bankers to discount all sound paper presented to them. Like their predecessors they viewed the matter exclusively from the point of view of normal trade conditions. They failed also to perceive the connection between the rate of interest charged by a bank and the amount of accommodation which its clients will demand. The "currency" school on the other hand were similarly obsessed with the problem of bullion export resulting from an unfavourable state of the exchanges. If all the currency in a country, they argued, were standard money, any export of bullion would reduce the currency; this would lower prices; the fall in prices would stimulate exports; increased exports would bring the bullion back. But since in England bank notes circulated side by side with gold, a void in the currency created by export of bullion could be replaced

1 Circulating gold cannot, of course, be drawn upon very largely ly the banks, however severe the crisis, since it is needed most for transactions which are relatively little affected by a crisis. 
by increased issue of notes, and this process may continue until all the bullion has been withdrawn. Therefore. it was desirable to tike action to restrict the amount of credit which should be permitted to circulate, and to prevent that amount from being increased to fill voids in the currency created by bullion export.

The proposals of the "currency" men were not entirely destruc. tive of the use of credit. In so far as they permitted the retention of a definite amount of credit in circulation, they secured for the nation the economy of that amount of capital. They were, however, far from liberal in drawing the limits within which this economy was to be circumscribed, nor did they face the certainty that the average amount of credit desirable at one date would be less than the average amount of creclit desirable ten years afterwards. Further. they did abandon altogether the second chief advantage of a credit currency. viz.. the steadying influence on prices which its clasticity offers. Finally they orerlooked the difficulty that their proposed automatic regulator would be nugatory, if they confined their attention to one form of banking credit only, and left others umrestricted.

The "currency" "school secured the support of Peel, and the Bank Act of 1844 gave expression to its views. The objects of that Act were to define the quantity of Bank notes which might circulate in Englant on credit, and to insure that the remainder of the circulation should be composed either of gold or of notes issued against a cent. per cent. reserve of gold. Clear rules were laid down which purported to relieve banks of issue of the task of judging the terms on which notes at any particular moment should be issued to the public.

The Bank of England was allowed to issue f14.000.000 against securities. and other issuing banks were similarly restricted to a total of $f 8,600.000$. Beyond the smms so specified. notes conld only be isstued by the Bank of England. which must hold against them a cent. per cent. reserve of golel. It was further provided that in future no new bank. whether private or joint stock. should issne notes, whilit if existing banks suspended their issue, or failed, or amalgamaterl with other banks. their right of issue should lapse.

\footnotetext{
1 In such cases the [Bonk of lingland wats allower] to increase its credit issue ley wo-thirds of the annomet of the lapsed isstre. As a result, the credit issue of the bink of lingland now amomonts 10 t $18,450,000$.
} 
The chief importance of this Act is the encouragement which it gave to the deposit and cheque system. Since further expansion of credit note issues was once for all prevented, expanding commerce and industry was faced by the alternatives of acquiescing in the expense of an all-metal currency ${ }^{1}$ and developing another form of banking credit. The result could not be in doubt; the use of the cheque was already general in London; throughout the industrial districts it has proved more convenient than the note could have been. ${ }^{2}$

The Act was, of course, quite inoperative to prevent monetary crises apart from skilful management throughout the banking world ; and in so far as it gave false confidence and complacency to the Bank of England by purporting to provide an automatic measure of the desirable note issue, it probably even postponed somewhat improvement in the Bank's methods. ${ }^{3}$ The restriction of issues against securities to a fixed sum made it more difficult for the Bankto handle a panic firmly. On the other hand, in a somewhat clumsy manner, it ensured that the beginning of a panic would never find the Bank absolutely denuded of gold. The serious crises of 1847 , 1857, and 1866 seem to show clearly that the greater stability which has been built up during the past forty years is not appreciably due to the Act of 1844 , but to a gradual growth of sounder banking organisation throughout the country, and a better understanding of the business throughout the banking profession.

The organisation of banking at the present day has grown from the reaction of two distinct traditions on the needs and possibilities of modern industry. On the one hand we have a strong Scotch strain, the result partly of perception of the advantage of Scotch methods, largely of the direct importation of men who had been trained in Scotland to organise and work the English joint stock banks. The survival of the English tradition - of the monarchy and central power of the Bank of England - is at first sight more

1 The clumsiness of handling metal in quantities was, of course, provicled against by the obligation on the Bank to issue any demanded quantity of notes against gold.

2 The restriction of note issues has probably affected agriculture injuriously. It has also possibly favoured large at the expense of small concerns generally throughout the country.

${ }^{3}$ It is difficult to come t) a conclusion on this point. The management at the Bank of England was bad before the crisis of $18+7$. In the fifties (as remarked earlier) a considerable improvement was shown which has since been maintained. 
surprising. And surprise deepens when we recall the embittered hostility shown by the Bank of England to the beginnings of rival joint stock enterprise. But the new banks had to grow gradually from small beginnings. and were therefore compelled to adapt themselves to the existing enviroment. And on the other hand Government left them free to do so-imposing on them no special rules which could divide them as by a watertight compartment from the private banks. The monopoly of joint stock banking, maintained by the Bank of England for 130 years, had given it ineritably a central position in the London money market. Private bankers cane to keep their reserves in the form of deposits with the Bank of England, and like all other dealers in money and credit looked to the Bank for support in difficult times. The limitation of the note issne, in 1844, still further strengthened the authority of the Bank. for it soon became evident that the Government would permit it to increase its issues beyond the prescribed limit in order to stop a panic, but would not give the same liberty to any other bank. And. indeed, no other bank had sufficient prestige to have made such a privilege of practical utility. Hence, in spite of bitter feeling, the joint stock banks boved to the prevailing practice, and kept their reserves in the form of deposits at the Bank of England.

The result has been an economy in the bullion basis of English credit, which finds no counterpart in any other country. ${ }^{1}$ This economy has been so far justified that the organisation of banking is incomparably stronger to-day than it was a century ago, and the bank of England has developed a technical calpacity of regulating the use of credit and managing difficult situations. Hence a striking difference between the history of credit in England in the first and second haves of the nineteenth eentury. From 1770 until 1850 it appears that the Bank of England's management was more or less kefective in every serious difficulty. From 1850 onwards it improved progressively, and since 1866 there has been no panic in England. This lats not been for lack of opportmity. There can be no reasonable clombt that if the baring appeal fror assistance had becen refused in 1890 as that of Overend and Gurney was in 1866 a a terrible panie would have ansued.

Disatisfation with the existing gold reserve is based rather on

1 The nearest patrallel is that of Ciemany. But the responsibilities of the Borlin moncy marliet are far smaller than those of Lemelon. 
fear of danger from without than of danger from within. So far as internal stability goes, a smaller reserve would be held sufficient; nor are such withdrawals of bullion, as could result from fluctuations in the course of commodity trade, much dreaded. The dangers in view are firstly political ; it is claimed that a hostile power might accumulate balances in London and withdraw them suddenly, thereby convulsing the credit system in time of war. Secondly, it is urged that a financial crisis in some foreign country might subject the system to a strain which it would be unable to bear. It is pointed out that, although our system has not hitherto produced a disaster of the first magnitude, the margin of safety is so small that the Bank is compelled to make more, and more considerable, alterations in its discount rate than either the bank of France or the Bank of Germany, and that these alterations are a considerable evil to the ordinary trade of the country. From these considerations have issued in the last twenty years a variety of schemes for increasing the reserve at the Bank. We may notice, especially, proposals that the joint stock banks should increase their balances at the Bank, that they shonld form a separate reserve (or reserves) to be used in emergencies, that the Government should lodge certain millions of gold with the Bank, that some millions of $f$ notes should be issued, and the gold withdrawn from circulation, or a part of it, added to the reserve.

The better organisation and technique of banking have prevented during the past forty years, those exceptionally serious disturbances of the money market which had been a feature of English commercial life for more than a century. The difference is sometimes expressed by saying that whilst "crises" still occur, "panics" do not. Neither of these terms is easy to define, but it may be said that whereas in a "crisis" the rates for short loans are abnormally high, in a panic short loans cannot be obtained on any terms at all. Both crisis and panic are in most cases the money market evidence of a more deeply seated economic evil. This evil has not, of course, been removed by the mitigation of its effects in one particular sphere of economic activity-viz., the money market-although it may be affirmed with confidence that improved management of credit has beneficial reactions throughout the business world.

We have noticed, in an earlier chapter, the phenomenon of periodic money market crises in the first half of the eighteenth 
century. In the financial world these events were strictly parallel, on their smaller scale. to the crash in New York in 1907. It may, however. be doubted whether their industrial influence was very deep; for the area of speculative investment was still restricted namowly. and there was no such interdependence between different parts of England as exists to-day. ${ }^{1}$ From 1760 onwards the rapid knitting up of districts. between which there had previously been little communication. by the new roads and canals. and the equally rapid expansion of banking credit increased enormously the potential evil of commercial crises.

The investigations of Jevons, thirty years ago, established the fact that between 1763 and 1878 there occurred twelve such crises at almost regular intervals of 104 rears. The actual dates were as follows: 1763, 1772-3, 1783, 1793, 1804-5, 1815, 1825, 1836-39, $1847,1857,1866,1878$. He pointed out that assuming 104 years to be the normal interval, the stock jobbing booms of 1711,1720 , and 1731-2 would fall into place in a regular series with the crises from 1763 onwards. He believed that he could trace some eridence of abnormal commercial expansion in 1742 and 1752 connecting the two parts of the series, and that similarly slight indications, in 1701, carried it back to the events of the early eighties and early 'nineties in the seventeenth century. He concluded that such regularity could not be due to chance. He ascribed it to fluctuations in the trade between England and sub-tropical countries, which, in their tum, were calsed by variations in the amonnt of heat given out by the sun. Of such variations he supposed that sun-spot fluctuations were an indication. He did not, of course, assume that no other cause of crises existed, or attempt to prove their absolute coincidence with sun-spot variations. His view was that a decennial meteorological period existed, and that during a part of it the economic world ineritably fell into a condition in which it was peculiarly liable to crisis. ${ }^{2}$ His case, again, is rather

1 It wold be difficult, in the noture of the case, to bring pesitive evidence in firour of this vew. Recurme monetary stringency certainly played a greal part in the commercial listory of the country, from the fourteenth century onwards, as witness the interest taken in the national supply of lmbin. Through the commercial capitalists it must lave reacted on the wage-earners-especially in the towns.

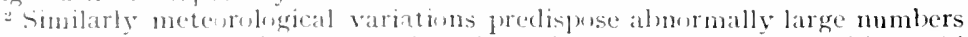
of imlividuals te certain chicases, lut the ultimate camse of my catching cold mat be not the existence of rain but the loss of my umbella. 
strengthened than the reverse by the disappearance of regular decennial periodicity since 1878. Starting from his belief that the decennial series of crises in England was due to a decemnial meteorological variation in sub-tropical comtries, it might have been predicted that as soon as those countries were displaced from their position of predominant importance in English trade, and were superseded by countries in parts of the world whose meteorological condition was different, the regularity of English crises would disappear. Now this is precisely what has happened in the last thirty years. There can be no question that our trade relations with India are relatively far less important now than they were then. It is at least interesting that this great shift in the conditions of our trade should have coincided with the disappearance of a phenomenon ascribed by Jevons to the influence of the East. ${ }^{1}$

Whatever the cause of the regularity of crises between 1763 and 1878 may have been, the fact of fluctuation in one economic world is of the last importance to the historian. The uncertainty which it occasions, together with the concrete ruin and want of which it is the cause, make up, perhaps, one half of the material evil of life. If it could be shown that it was either increasing or decreasing in intensity, such a fact would equal in importance the facts of technical progress. Unfortunately the data at present available permit no definite conclusion.

At the outset the question arises whether the closer interdependence of individual fortunes, which has resulted from the Industrial Revolution, has made the ebb and flow of economic activity a more serious evil than it was before. If the comparison be made between modern England and the England of the early Middle Ages, it can hardly be doubted that the evil is greater to-day, but we must remember that an evil of considerable magnitude has been removed by the same causes that have produced our modern problem. In the twelfth and thirteenth centuries local dearths of food, occurring at irregular intervals as the result of crop failure, were a normal element in life. Such serious and widespread famine as was alleged,

1 Jevons expressly disclained the view that the sun-spot fluctuations coincided with perceptible periods in the meteurology of Europe (though he noted a coincidence between sun-spot minima and vintage years), and he remarked that those nations of Europe which had little or no direct connection with the East appeared to escape the regular crises. 
on one occasion, to have produced cannibalism, was no doubt very rare. but minor hunger years were of normal occurrence. "Bad times," in the sense of food prices. which strained the purses even of those in full employment, continued to recur at intervals until the middle of the nineteenth century. It may be doubted, however, whether the distress from this cause, even in the worst years of the Napoleonic wars, was at all comparable with the evil of a medieval famine, for the supply of food. however inadequate, was better distributed throughout the country. The years between 1780 and 1850 were, of course, worse in this respect than the succeeding period. In regard to the intensity of cyclical changes in the activity of trade and production, evidence is lacking for a full comparison of the two periods. It is, however, probable that in this respect also the earlier period was worse than the later. The weakness of banking organisation and the revolutionary transition in industry were factors of disturbance, which have since been nitigated or removed; and it should be remembered that during the last fifty years the wageearning classes have possessed an increasing power of directing public attention to their grievances: we must, therefore, in order to institute a just comparison discount somewhat the evidence available during the later period and einphasise that which exists for the earlier. Even without such rectification of evidence the impression produced on contemporaries by the evil of crises and depressions is striking enough. It is, however, a difficult task to disentangle from general descriptions of misery the effects which were due to cyclical depressions as such, and the effects which were due to the coincidence of an exceptionally low stantard of life with cyclical depressions. There is some danger that we may suppose that the violence of eyelical depressions has been reduced in modern times because mose individuals are able to save or insure against the evil which they produce. 1

If we consider the conditions of modern industry in contrast with those which existed before the Industrial Revolution, we gain the impression, as noticed above, that the area within which periodic contraction and expansion were perceptibly felt was smaller. It is, however, doubthul whether the net instability of inclustry is greater

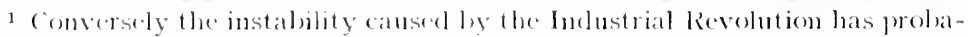
bly beren olten exaggerated because the loss of common rights and gardens mate the new town operat ive more dependent on regular employment than the domestir worker in the combry had heen. 
now than at any time since the wage system developed. If we consider the evidence which remains from the sixteenth and seventeenth centuries, we are impressed by the magnitude of the evil of recurrent lack of employment. It can hardly be doubted that even if the labour market throughout the country did not experience those regular fluctuations which disturb it to-day, each local labour market experienced them independently, and that the cvil was as great as, if not greater than, it is to-day.

The accumulation of statistical data in recent years makes it possible to trace in considerable detail the fluctuations of economic activity. ${ }^{1}$ Between 1879 and 1904 three periods or cycles of boom succeeded by depression. may be traced, exercising a coincident influence in many different fields. Bank rate, employment, foreign trade, marriage rate, indoor pauperism, the formation of companies, show parallel movements. The furst cycle fell between 1879 and 1886 . Starting from the depths of depression in the former years improvement was rapid in 1880-1, and culminated in 1882-3. Thenceforward the decline was rapid until 1886 . The second cycle lasted from 1886 until 1894. It culminated in 1889-90. The third cycle was from 1894 to 1904 , culminating in 1900.

The data available are still too imperfect and the period for which even these imperfect data exist is too short to warrant a decisive answer to the question whether the extent of fluctuation is growing or declining: it may, however, be asserted with confidence that no emphatic tendency in either direction is visible.

1 An excellent chart is inserted by Mr. Beveridge in an article on "The Pulse of the Nation," in the flbany Rericu, Nov., 1907. 


\section{CHAPTER VIII}

FINAXCE AND NATIONAL WELFARE

THE history of English finance between 1760 and 1900 can be divided conveniently into four periods. The first runs from 1760 to 1792 ; the second includes the great French wars. 1793-1815; the third carries us from 1815 to 1875 ; the fourth concludes the nineteenth century.

I. 1760-1792. By the end of the Seven Tears' War the traditions of Walpole had been lost sight of, but "The Wealth of Nations" (1776) influenced North to some extent, and largely determined the fiscal policy of l'itt during his peace administration (1783-1792). In his treatment of the tariff he anticipated Huskisson by simplification and reduction of duties, and also by encouragement of trade with competing nations. ${ }^{1}$ He made great technical inprovements in the machinery of taxation and of national accounting. and pursued a strong policy of debt reduction. His efforts were rewarded by a rapid increase of financial solidity. Consols had stood at about 57 in 1783: in 1792 they rose to 97.

II. 1792-1815. The French wars occasioned a great increase in taxation. and a vast growth of the National Debt charge. At their commencement the expenditure (apart from debt redemption) was between eighteen and nineteen millions; the debt was 240 millions. At their close the expenditure was 100 millions (of which 75 millions were raised by taxation). and the debt (funded and floating) 876 millions.

It seems clear that Pitt underestimaterl altogether the importance of the war in 1793. It was not until 1797 that loe made serious (efforts to increase the tax reveme, and even in his loan operations he harl procedert so asually, overtrawing unduly the national arcount at the Bank of England, as to make necessary a stoppage of rash payments in 1797. From that date onwards taxation was increased rapielly. Lut the lost sromel could not be entirely regained. The increase of the debt between 1793 and 1797 had swollen the annual ifelot charge, and impaired the credit of the

1 Sluwn especially in the crmmercial treaty with France of $17 \mathrm{~s} 6$. 
country. ${ }^{1}$ The stoppage of cash payments produced enormous price fluctuations, and reduced upon the average the purchasing power of the sums raised whether by taxation or loan. From another point of riew the strain involved by the war was useful, since it compelled fiscal experiments which might otherwise have been long postponed. It is doubtful whether Peel could have levied an income-tax in time of peace if Pitt had not previously done so in time of war. But the country emerged from the war with an indiscriminate mass of taxation which pressed on almost everything that could be taxed. It should be noted also that throughout the war period the local rates for poor relief rose rapidly-especially in the agricultural districts. Between 1793 and 1802, Pitt increased the capital liabilities of the State by 270 millions. The sum actually received in cash was considerably less, for the new stock was created uniform with the old 3 per cents., and a very large discount was necessary to attract lenders. It is clear that Pitt understood that this method of raising money was less desirable than borrowing at higher rates of interest and keeping down the capital of the debt. He made, in fact, several attempts to do the latter. It may be that he did not try hard enough, but his acknowledged fertility of resource makes it more probable that he understood the investment market, and only accepted what really was inevitable. He has also been criticised for keeping a sinking fund in operation, although he was borrowing the money for it. Here again we should probably accept his judgment that this plan gave investors a confidence in the stability of English finance which more than made good its cost. The finance of his successors is less casily defended.

III. 1815-1875. During this period the system of raising revenue for the central Government was throughly recast, and assumed a form which it has retained without much modification down to the present day.

We note first the gradual clearance from the tariff of taxes on more than a thousand articles. Those retained were levied on widely used luxuries, ${ }^{2}$ which were capable of yielding a considerable revenue; secondly, a similar policy was pursued with internal taxes on commodities. and the taxes levied upon them were made as nearly

1 The three per cents. had reached 97 in 1792. In 1797 they fell below 50.

2 The luxuries in question are, of course, all of them "conventional necessaries." 
as possible equal to the customs duties on the same commodities or substitutes for them. These changes. which are usually summed up under the term " free trade movement." began during the tenure by Huskisson of the Presidency of the Board of Trade, 1823-7. Ther were continued by Peel during the years $1842-6$, the budgets of 1842-5-6 being of most importance. In the years $1846-9$ taxation of imported corn was gradually abolished, ${ }^{1}$ the removal of protective restrictions on navigation begun by Huskisson was completed. and Colonial preferences disappeared, with a few unimportant exceptions. The work of freeing the tariff and removing internal taxes was continued by Gladstone in 1853 and 1860 . The tariff treaty negotiated by Cobden with France in that year provided for the abandomment of the remains of the protective system. The last step in the simplification of the tariff was the abandonment of the sugar duty in 1874 .

The incone tax, which had been made by Pitt and his successors to provicle a large revenue ( $15,000,000 \mathrm{in} 1815)$. Was removed in 1816 against the judgment of the Govermment in deference to its mpopularity with the classes represented in the Honse of Commons. The entire loss of so large an item in the revenne was one of the main reasons of the slow progress of fiscal reform down to the commencement of Peel's administration in 1841. In the next year he revired the income tax as a temporary measure in order to make remissions of taxation, which he believed would react farourably on the revenue derived from the taxes which were retained. The continuance of his reforms made necessary the retention of the tax, but in 1853 Gladstone still represented it as a temporary expedient. and held ont hopes of its removal in seven years' time. These hopes were frustrated by the Crimean War, and the cost of military preparations against the fear of a French invasion. The last proposal to abanden it came also from Gladstone in 1874 .

The treatment of the debt was weak thronghont the period-at some times culpally so. The sinking fund was linally abandoned in 1829, it being arranged that any actual surplus at the close of a year should be utiliserl for debteduction. between 1830 and 1840 , so far from such surpluses being realised, the capital of the lebt was actually increased ly marly $8,000,000$. Mcantine, however,

1 A duty of one shilling a puarter was retained until 1869. 
the relatively small amount of stock which hore 4 or 5 per cent. interest had been converted into $3 \frac{1}{2}$ per cent. Peel secured surpluses by his revival of the income tax. In 1844 he converted the $3 ! 2$ per cent. stock to $3 \frac{1}{4}$ per cent. for ten years, and 3 per cent. afterwards. In 1853 Gladstone attempted to create a $2 \frac{1}{2}$ per cent. stock, but failed in consequence of the Crimean IVar. The finance of the war was. on the whole. commendable. Of a total of $770.000,000$ expended, only half was raised by loan. Between 1856 and 1875 no very serious effort was made to pay off debt. Surpluses. and even windfalls in the nature of capital. were spent on reducing taxation.

IV. 1875-1908. Since 1875 the most important points to be noticed are :

The final adoption of the income tax as a normal method of raising revenue, and the attempt, in the Budget of 1907, to distinguish between earned and unearned incomes, the latter being taxed at a higher rate than the former.

The policy, begun by Harcourt in 1894. of securing for the State a larger proportion of property passing at death.

The revival. during the Boer War, of a small protective duty on corn. an export duty on coal. and a sugar duty. and the subsequent abandonment of the first tro, and the reduction of the last.

The sinking fund of Sir Stafford Northcote in 1875. the Goschen conversion. in 188s. of the 3 per cent. stock to $2 \frac{3}{4}$ per cent. $(212 \mathrm{in}$ 1903). the addition of some $\$ 160,000,000$ to the debt by the Boer War. and the considerahle repayment of debt in the years 1906-8.

The most interesting side of these derelopments is the gradual abandonment of attempts to direct the course of production at home by differential taxes on imports from foreign countries. The first step in this direction was taken by Pitt under the influence of "The Wealth of Nations." But the movement was strangled by the financial stress of the war period. Indeed, in one respect the task of the free traders seemed more difficult in 1815 than in 1792 . In the interval a strong demand for protection had arisen among members of the agricultural interest. The rank and file of the Tory party were beginning to supersede the Whigs as the convinced exponents of protection. During the war the prices of food stuffs generally, and especially of wheat. ruled very high. This was due partly to an unusual number of bad harrests. partly to interruption of trade with the continent, partly to currency inflation. 
The high prices had caused land speculation. and as they fluctuated within wide limits. speculation had often failed. At the conclusion of peace men who had made long period contracts in the expectation that the war prices would continue, demanded a scheme of protection which would keep prices in the neighbourhood of 80 s. a quarter. The traditional policy of the State was, as has been seen, to favour corn growing, and one of the best established criteria of national prosperity was a rise in rents. No new principle, therefore, was involved in acceding to this demand. though it was, of course, a change in practice of first-rate importance. The attenpt to keep wheat prices up to 80 s. a quarter was entirely unsuccessful. The country was not dependent on foreign nations for any large part of its supply. The average annual price might rise exceptionally to 96. (as in 1817) or fall exceptionally (as in 1835). to 39s. a quarter; in more normal years it fluctuated between $50 \mathrm{~s}$. and $70 \mathrm{~s}$. It is difficult to form an opinion on the extent to which the mean level of corn prices was raised in England by protection between 1816 and 1846. Comparison between the prices in England and Prussia show a big difference to the disadrantage of England. This comparison, however, does not answer the question, for had there been free importation the increase in the English demand for Prussian wheat must have raised prices there appreciably. ${ }^{1}$ The more academic advocates of free trade in corn. though they anticipated some increase in inportation and reduction in average price, did not expect much of either. So far as immediate effects were concerned, more was hoped from the prospect of greater price stability. The free traters were also concerned with the "dynamics" of the situation. It was clear that as the population increased the pressure of the inuport duties would be more and more felt, whilst at the same time foreign countries mable to sell goods in England, woukd be chootraged, and in some measure compelled, to make themselves independent of English manufactures. The arguments that the com duties constituted a tax on the food of the people, and that the forces at work were likely to make them more rather

1 The following averages of the pice of wheat per fluteter, in a number of English and prossian markets have been calculated from figures in ed. 2337.

$\begin{array}{cccc} & \text { linglint. } & \text { Prussial } & \text { Excess of linglish Prices. } \\ 1820-9 & 59 / 9 & 26 / 1 & 33 / 8 \\ 1830-9 & 5(3 / 8 & 29 / 8 & 27 /- \\ 1810-5 & 56 / 8 & 31 / 1 & 22 / 7 \\ 1850-9 & 53 / 1 & 44 / 6 & 8 / 10\end{array}$


than less burdensome in the future, could not be seriously impugned, nor could they be met by a demonstration of advantage derived from the duties by farmers and agricultural labourers. English agriculture was in a state of chronic depression between 1815 and 1846, largely on account of the uncertainty which resulted from price fluctuations. One public inquiry followed another without perceptible improvement.

The advocates of agricultural protection advanced two serious arguments. The first was the importance to the State of the landed interest. Few men were hardy enough to contest the claims of the landowners to exercise a predominant influence in politics, and few could fail to perceive that their influence in politics would decline if rents were not maintained. I It is probable that the effect of the corn duties in raising rents was considerably exaggerated, but this exaggeration was shared by the great majority both of protectionists and of free-traders. To men who really valued the system of Parliamentary govermment by a landed aristocracy, under which the international influence and imperial greatness of England had been achieved, every speech in which an anti-corn-law orator showed the connection between high prices and high rents supplied arguments in favour of the duties. It was felt also by many that in addition to the work done by the rentiers in legislation, in administration, in the Church, and in the services, they had acquired a vested interest in the maintenance of rents at something like the figures they had reached during the great war. Mortgages and rent charges had been placed upon estates in the expectation that their value would not fall; and not all the increased value had actually gone into the pockets of the landowners, for the Poor Rate had risen with the rise of rent. It is difficult for modern Englishmen to appreciate at this distance of time the importance which was attached to landowners as such. The democratisation of politics and of the Civil Service has opened Parliament, local govermment, and the services, to all classes of wealth, and even in some degree to men who are poor. But this fusion and confusion of the propertied classes has arisen out of conflict between land and capital, and in one of its aspects the free trade movement was a phase in that conflict. Repeal became the cause of the rising manufacturing class. It meant that the increased food supplies should be procured in exchange for manufactures, and not extracted from the soil of England. Finally 
sober statesmen had not, in 1816, abandoned the hope that the country might once more be made self-sufficing in respect, at least, of wheat. It could be pointed out that the wheat acreage and output had been increased enormously during the war, and that there was still room in almost all districts for the adoption of the new methods of culture whose superior economy had been demonstrated. One realises the force with which these considerations came home at the time by the impression which they could make on such a man as Peel. His attachment to the landed interest was an affair of one generation only. ${ }^{1}$ His father, the first baronet, had made his money in cotton. In accordance with English tradition he had bought land, but the family connection with manufacturing enterprise continued, and the great Sir Robert had thus a foot in either camp. It cannot be supposed that his long continued resistance to repeal was determined either by sinister interest, or by political ambition, or by the cruder sort of protectionist fallacy; the arguments in favour of the corn laws had so much cogency that the severest and least self-seeking of the statesmen of the period believed them to be desirable until $1840 .^{2}$

The course of events steadily weakened the case in favour of the laws. In the first place they failed practically to maintain prices at the war level./ Men who had speculated on the assumption that sucli prices would continue gradually admitted defeat. The new leases and the new purchases were adjusted to a lower scale. Secondly, after 1835 , the prospective reduction of the poor rates could be used as an argument for removing agricultural protection. Thirelly, the hope that the country would become self-sufficing dwindled through non-fultilment. Lastly, and most important, it became more and more evident that the system of high protection complicated by sliding scales, so far from encouraging agricultural improvement, was more likely to delay it hy increasing the risks of farming. Under other circumstances the expedient of substituting a small invarialse duty of $5 \mathrm{~s}$. or $10 \mathrm{~s}$. a quarter might have been tried, but in the meantime the fecling against the bread-tax had grown so strong that such a measure was politically impracticable. It would, in fact, have displeased both parties-

1 Pecl's ancestors, however, had luen yeomen farmers.

"The exact date of leel's clange of opinion camnot le fixed, since the change wats a gratual process. 
both the landlords and the anti-corn-law leagne wanted "the whole hog."

Apart from the corn duties the two chief centres of controversy were the colonial preferences in favour of Canada and the West Indies, and the Navigation Acts. In regard to the first the economic case against the most important preferences was particularly strong. It was obviously undesirable to raise the prices of sugar and timber. A reciprocal preference in Colonial markets was not at that time of great importance partly because the markets themselves were not very capacious, partly because English exporting industries had little fear of foreign competition if only the English tariff were reformed in the free trade sense. The breach with the United States and its subsequent effects had weakened alike the economic and the political argument for preference. On the one hand experience had shown that the severance of political ties, and even recurrent war, had not involved the loss of the American market to English exporters; on the other hand the case of America had convinced men of very different temperament and political opinion that English colonies would eventually break away from the mother country. Against the Narigation Acts also weighty arguments could be urged, whilst little could be said in their favour. Here, again, the breach with the American colonies exercised a great influence. The American Mercantile IIarine grew rapidly in power. and the States could afford to wage a war of reprisals disconcerting to English business. It was in particular impossible to maintain permanently the attempt to exclude them from the trade with the West Indies. Such attempts were certain to be largely futile in view of the facilities for smuggling, and they would, nevertheless, be exceedingly vexatious to the West Indian colonies. In Europe also reciprocal exclusion of English shipping was imminent.

Apart from the three great questions-Corn I.aws, Colonial Preference, and Navigation Acts-the reform of the English tariff was largely non-controversial. Its technical defects could not be denied. The vast majority of the duties brought in practically no revenue, and were at the same time costly to collect. Many of them weighted important raw materials, whilst very few manufacturers were seriously dependent upon them. Until 1860 low duties on a certain number of finished manufactures, especially woollens, 
silks, and articles of fashion was retained. That they were admittedly unimportant seems clear from the fact that the landed interest did not Joudly demand their removal in return for the repeal of the Corn Laws, and from the sluggish opposition to their abandonment in 1860. A point of some interest is the fact that they were abandoned in consequence of a commercial treaty with France, a revival and extension of the scheme for closer relations. which had been first planmed in 1713. and first essayed in 1786. On several occasions between 1830 and 1848 negotiations for a treaty had been opened between the two countries, but the government of Louis Philippe was too weak to stem the current of protectionist feeling in France. Napoleon III and his advisers possessed both the will and the porver. A gradual reform of the French tariff analogous in some respects to the English movement was commenced in 1854. The "Cobden" treaty of 1860 marked an important stage in its execution. There is no reason to suppose that the concessions made by England weighed much with the French negotiators as compared with their desire to reform their own tariff. In fact, they went further than their word. Having pledged themsclves in the actual treaty to reduce their duties on English manufactures to within a maximum of 30 per cent., the duties, as eventually assessed, ranged in most cases from 12 per cent. to 15 per cent.

It scens clear that although a great part of the free trade reform was not intencely controversial, the popular tradition which associates that movement with the activity of Cobden and Bright. is in the main correct. The general clearance of the tariff - in the existing state of the country-deserves to be classed as primarily a resenue expedient, an application of the tolerably self-evident proposition that it is wasteful to keep up costly Customs House supervision orer articles which only yield small amounts of revenue, and that the yield from an asticle must be large in order to outweigh the inconvenience to traders which results from taxing it. In regard to this side of the matter the question of foreign competition harlly arose, except in so far as it was perceived that complete frectom in the purchase of raw materials and plant would assist the English manufacturer to hold foreign markets. In the absence of a really strong demand for protection this cumbersome and extravagant system of taxation was sure 
to be greatly modified. In regard to the Navigation Acts, to Colonial Preference, and to Agricultural Protection, there were strong arguments to meet. The greatness of Cobden and Bright was their ability to deal with those arguments. When this hat been accomplished, the less reacted to the greater-in other words a spirit of principle gradually penetrated into the minor matters of revenue policy. Duties like the five per cent. on woollens, or the 1s. a quarter on corn, which in themselves could never have roused strong opposition, were gradually removed. Men were convinced that they were undesirable in principle, and they had such a horror of the system of protection that they took a lively pleasure in watching its last vestiges vanish. This fiscal purism, therefore, must also be regarded as a legacy of Cobden.

The influence of the free trade policy of England upon its subsequent economic development has been considerable. It may, however, easily be cxaggerated. If, for instance, we compare the listory of Germany ${ }^{1}$ during the past thirty years with that of England, we find a striking similarity in its general tenor. In Germany, as in England, we find much agricultural distress resulting from transoceanic competition, complaints of the drift of labour from the country to manufacturing towns, rapid expansion of exporting industries, increase of economic integration with other parts of the world. There are, of course, minor differences: thus in spite of agricultural depression the German output of cereals has been maintained at enormous cost to the consumer; and whilst the English export coal, the Germans, with equal "recklessness," part with their "irreplaceable native supplies" of iron. It is clear that in neither country is fiscal policy the principal determinant of the course of progress. One potent cause of misconception on the subject has been the acceptance of foreign trade statistics without duc examination and with undue confidence in their adequacy to measure progress. Between 1846 and 1873 the free traders generally were great offenders in this respect. Not only did they habitnally exaggerate the part played by their policy in aiding trade expansion, but they exaggerated the extent to which trade had expanded. When it was said that trade was " expanding by leaps and bounds" it should have been added that much of the apparent increase was due to the rise

1 The German reaction towards protection may be dated from the Tariff of 1879 . 
in prices, in other words to an alteration in the unit of measurement applied to trade. We have. of course. in the last few years seen more use made of this particular fallacy by opponents of the free trade policy. Between 1873 and 1897 the general course of prices of both exports and imports was downward. with the result that although quantitatively the trade of the country continued to expand rapidly its values showed comparatively small increases from one decennium to another. The upward trend of prices in the past ten years has brought us to another period of apparent "leaps and bounds." The fact seems to be that from 1855 onwards the expansion of English trade has been strikingly regular and continuons. It is unfortunate that the statistics for the earlier half of the century, and for the last forty years of the eighteenth century, are too unsatisfactory to warrant detailed deductions. It cannot, however. be questioned that the period of the Industrial Revolution witnessert an enormous and rapid expansion of trade, and that the coincidence which placed the gold discoveries in California and Australia immediately after the great free trade reforms of $1842-9$ misled contemporaries into supposing that the acceleration of the rate of increase in the 'fifties was greater than it actually was.

It appears to be generally admitted that the influence of the new policy on agriculture was, if anything, favourable until the later 'seventies. ${ }^{1}$ After a short period of despair landlords and farmers accepted the new situation and set themselves to meet foreign competition by high farming. Their efforts were assisted by a depreciation of gold, which lightened the burden of mortgages and long leases. It was during this period that the movement towards large farms, which hat commenced in the eighteenth century, culminated. A somewhat rigicl organisation of agriculture resulted from the assumption that the main use of land was to produce bread and meat. This assumption was no longer justifiable after the resources of the new comntries began to be opened up, and it rirl little to fit the agricultural interest to meet the difficulties which were approaching. When all clue allowance has been made for the very considerable activity and inploring spirit shown by landkrds and farmers between 1850 and 1875 , the general verdict must be that agrieulture remained an affair of routine and tradition -a gerel routine and a somel tradition so long as the conditions

1 At least more favourable than the sliding scale system. 
to meet which they had been evolved remained, but useless or even pernicious when those conditions altered. It is incredible that if agriculture had been directed by the type of man which directed manufacturing industry the necessity of retrenching cereal production would have involved so much suffering. Up to the present time the dominant classes in agriculture have shown themselves upon the whole unable either to learn from those parts of Europe which have met the storm successfully, or to devise expedients of their oirn. Neither continental protection nor the absence of protection in England has given over the English marliet for fruit, and poultry. and dairy products to European farmers. In one way and another the English land system has hampered application to the land of brains and capital. Meantime the ruin and loss of capital, which have resulted from the great fall in food prices. have been considerable.

On a merely numerical reckoning it may be maintained that eren during the past thirty years free trade has done more good than harm to agricultural interests; for the labourers outnumber many times the farmers and landlorts, and there can be no question of the importance to this class of cheaper food. Given equality of attractiveness between town and country life the reduction of cereal acreage might have counterbalanced this advantage by increasing unemployment; but the conditions of country as compared with town society have increasingly repelled the abler men among the labourers, and driven them into the torns. Hence a considerable increase in normal wages in addition to their increased purchasing power. More important still is the fact that the crumbling of the existing land system beneath the blows of foreign competition gives hope of better organisation of rural life.

The English free traders of the middle of the nineteenth century did not foresee the shock to European agriculture which has resulted from transoceanic competition during the past thirty years. In another respect also they miscalculated the future. They had hoped that the adoption of free trade by England would influence other nations permanently in the same direction. Their prophecies on this subject held good for thirty years after the repeal of the Corn Laws: between 1846 and 1876 the current of European opinion and practice flowed strongly in the direction of liberal tariffs; but this could not continue indefinitely. The economic 
arguments in favour of protection are in some cases too strong, in all cases too plausible, whilst the very rapidity of certain developments which make against the permanent maintenance of existing national divisions has irritated the susceptibilities of nationalism.

The conditions of English industry, at the time when the free trade policy was adopted were evidently very different from those which exist at present. Anyone who glances at the evidence collected by the Select Committee on Import Duties in 1840 will see that the manufacturers, generally speaking, were confident of their power to meet foreign competition. ${ }^{1}$ Since then foreign competition has become a more and more serious factor in their calculations, and it is certainly worth considering whether the policy of free imports now exposes them to undesirable dangers. History unfortunately throws rery little light upon the problem, ${ }^{2}$ but one or two points may he made. The growing complexity of production and the greater strain of competition have made the country more dependent on the advantage of free choice of raw materials, half-finished manufactures and plant. However important this freedom may have been sixty years ago, it is more important now-both absolutely, becanse the fall in transportation charges has made feasible the collection of materials from greater distances, and relatively, because our advantage in other respects is less. It is sometimes urged on the other side that dependence on foreign supplies will ultimately canse an increase in their cost. Of this there are many prophecies, but so far no historical evidence. In some cases where it is represented as probable the English industry is already organising itself to make it impossible. Thus the chance that the English shipbuilding industry. after coming to depend on German steel, will find the price rased against it, is rapidly vanishing, as ship-building firms integrate their business with steel-producting plants, and arrange to produce for themselves at least a part of their supply. Historical data might show that a protective tariff, upon the whole,

\footnotetext{
1 Some allowance must be mate for natural optimism in view of any propesel change for which a plausible case can le mate ont. There were no fouble then, as there are now, many men who weleomed the proposed change for utterly materguater reasons.

2Asmming, that is, that mere post hoc, propter hoc, arguments, as that lingland lats prespered mere under a free trate policy, or that fermany has

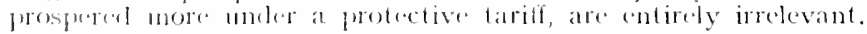


steadied production and prevented or reduced the evil of unemployment. Such data as exist are, however, on the whole opposed to this view. The history of "dumping" shows that it is effected in protected as well as in free markets; whilst industrial instability is increased in the former by variation of the tariff. It may be argued that the absence of a tariff has prevented in England the rise of combinations which would steady production by granting at times export bounties on a part of their product; but apart from the historical arguments which may be urged against any acceleration of the Trust movement, it may be questioned whether the fiscal policy of England has delayed it much. ${ }^{1}$

It remains only to notice the part played by the free trade movement in the development of opinion as to equity in taxation. Adam Smith had laid it down that taxation should be levied in pro portion to revenue, but the aim of mid-Victorian finance seems to have been to procure it almost entirely from taxes on the luxuries of the working-classes. On the one hand it was desired to exempt from taxation the minimum necessary to maintain life, on the other hand it was believed that an ad valorem tax on all incomes above the minimum would reduce the national dividend by restricting accumulation. From the 'seventies onwards a gradual change can be traced in which the first stage is the abandomment of the hope of entirely dispensing with the income tax in time of peace. The view that a proportion of the income of all individuals whose incomes exceeded a certain sum ought to be secured for the State led up to the view that the proportion taken should increase with the size of the income, and should be larger in the case of unearned incomes. Partial effect was given to these views by the change in the income tax in $1907 ;^{2}$ and their influence appears also in the tendency to increase that proportion of the total revenue which is levied by direct taxes from the wealthier sections of the community. This end has been obtained by raising the normal level of the income

1 These arguments will naturally have no weight with those who believe either that the British Empire can only be maintained lyy a preferential system, or that the demand for labour in England is diminished by imports.

2 Some advocates of progressive taxation have claimed that the old " abatement" system made the income tax in effect progressive, and that their demand is therefore merely for the logical development of principles alreacly accepted. It is, however, probalule that the abatenent system was inteneled to balance the severer burclen of inflirect taxation on small incomes; its object was to prevent regression, not to institute progressive taxation. 
tax. and by a large increase in the death duties. which have also been graduated so as to press more hearily on the rich. But although the problem of equity in taxation has roused more attention. it camnot be said that it counts for much yet in practical finance. It is probable that the danger of loss of rotes has done far more in determining the changes which have been made than conscious and reasoned principles. No Chancellor of the Exchequer has yet felt it part of his duty in presenting his Budget to the House to offer even an approximate estimate of the percentual weight of taxation which his scheme as a whole will impose upon different classes of society. 


\section{APPENDIX I}

\section{WAGES AND PRICES}

THE problem of calculating the real wages of labour in England began to attract attention at the close of the eighteenth century. On the one hand collections of contemporary evidence were begun both by private individuals and in government enquiries; on the other several writers tried to collect evidence for earlier periods. In regard to the latter problem little real progress was made until the third quarter of the nineteenth century, when Thorold Rogers published a mass of price and wage statistics derived principally from MS. sources; this collection remains the prime authority for the years from 1270 until the close of the eighteenth century. From about 1760 onwards the mass of available material grows and becomes almost unmanageable in the last decades of the nineteenth century.

Since the death of Thorold Rogers much has been done by English students towards a history of wages in the nineteenth century; they have, however, left the history of wages before 1790 almost untouched. Even the work done by Thorold Rogers has been somewhat neglected by later historians ${ }^{\mathbf{1}}$; Dr. Cumningham in a short appendix to his third volume summarises some of the difficulties involved in the "Interpretation of Historical Statistics." 2 and gives "for what they are worth" the calculations made by Young in 1812, in preference to the results of Thorold Rogers' more elaborate investigation.

Meantime the whole field has been surveyed by a Swedish writer -Dr. Steffen-in his " History of English Wage-earners." which is accessible in German to students but is still, for lack of a translation, closed to the majority of Englishmen. Dr. Steffen has kindly permitted the present writer to reproduce in the accompanying charts some of the results of his investigations. Chart A shows the movements of the daily wages of a carpenter and an agricultural

1 An exception should be made of Prof. Hewins, whose " English Trade and Finance" contains a chapter in which Thorold Rogers' statistics for the seventeenth century are examined.

2 Cunningham, "Growth of English Industry and Commerce," Vol. III, pp. $927-9+2$. 
labourer by decennial averages. Chart B collates these movements with movements of the price of wheat, and shows therefore the wheat purchasing power of the two wages at different periods.

The distrust of wage and price statistics for early periods which has characterised the work of English economic historians of late years is a natural reaction from the tendency of Thorold Rogers (and still more of those who quote his conclusions) to simplify unduly the problem of comparing the position of wage-earners at periods separated by centurjes. A glance at Chart B shows that a day's wages, measured by the quantity of wheat which they would purchase. were greater for both skilled and unskilled labour between 1440 and 1490 than at any subsequent period until the past half century. However authoritative might be the data on which such a conclusion was based, it is clear that when we are comparing civilisations so different as those of the Wars of the Roses and the Reign of Queen Victoria the amount of bread consumed under each is of subordinate importance. To take only one point: at the present day the majority of Englishmen ${ }^{1}$ can only afford occasional trips into pure air, whereas almost any Englishman in the fifteenth century could get it every day; on the other hand the foulness which we breathe is largely caused by domestic fires and lighting which give possibilities of health and comfort formerly unattainable even by the rich.

Even where periods immediately succeeding one another are compared, as, e.g., the fifteenth and sixteenth centuries, considerable care must be taken in drawing inferences from these wheat-wage statistics. In the first place the data themselves, the actual wage and price quotations from which the averages have been prepared, may be impugned: secondly, we know little of the variations in the length of the working day and the regularity of employment which may have taken place.

As regards the former point. comparison of the two curves on Chast A will perhaps do something to mitigate the rehotance which some historians feel in attaching weight to the figures collected by Thorold Rogers. With all his laborious research Rogers was never able to probure many duotations of the price of an article or the wage for a certain kind of labour in any one year, and many students have no doubt suspecterl that his results were in consequence ahmost

1 The term here inclurles, of course, men, women, and children of all ages. 
arbitrary. Comparison of the two curves on Chart A shows on the contrary that in almost any selected period of thirty years the trend of the two curves is identical; the correspondence between then is just about as close as theoretical considerations would lead us to expect; it is almost impossible to believe that it is accidental.

Even if we accept the conclusion that the general shape of the curves represents approximately the broader movements of wage rates during the past six hundred years, there remains the difficulty of arguing from daily wages to the real income of the labourer without knowledge of changes in the number of days worked per annum.

To turn now to the curves themselves, a rapid rise in the standard of living seems to have occurred between 1300 and 1450 ; improvement certainly showed itself before the Black Death; it was, however, particularly rapid in the years 1370-1400. From 1440 to 1500 no persistent tendency is apparent, but there are considerable and marked fluctuations; during the sixteenth century, on the other hand, the tendency of both curves was persistently downwards, though there was a temporary improvement in the first decades of Elizabeth's reign.

These movements seem to fit the history of the three centuries from 1300 to 1600 closely. A slow improvement began about the accession of Edward III ; it was interrupted for twenty years by the Black Death; later, when the rise in prices which temporarily resulted from that disaster had ceased, the increased demand for labour did its work-producing an almost unchecked rise in wages during the next half century. On the other hand in the sixteenth century enclosures and rising prices, together with minor evils, depressed wheat-wages enormously. But though the general shape of the curves during these three centuries may be accepted, the deductions which should be drawn as to the condition of the wageearners remain doubtful. It seems, indeed, to be written on the face of the statute book that the position of the wage-earner improved after 1350 , and was tending downwards in the sixteenth century; in the history of the treatment of destitution and of the regulation of labour the government passes from a policy mainly directed towards preventing the labourer from improving his position to one which is, at least in part, inspired by the desire to save him from a lower standard of life. But the extent and 
importance of the rise in real wages between 1350 and 1450 , as of their fall in the sixteenth century, must always remain matter of controversy.

Into this controversy we camnot here venture. but the attention of the student is directed to two tendencies which, among others, mitigated in the sixteenth century the evil effects of the enclosure movement and the rise of prices; first, the spread of domestic industries throughout the country districts, which in many cases must have increased the family income materially; second, the considerable improrement in housing and furniture which was one of the results of the growth of mannfactures: as glass came into the windows even of the poor, as half timber or brick replaced wattle and daub, many must have gained more by the increased comfort of the home than they lost by the increased cost of food.

The shape of the curves after 1600 similarly confirms. and is confimed by impressions derivable from the general history of the country. A new period of upward motion begins soon after the micklle of the seventeenth century, and leads to the comparative prosperity of the first half of the eighteenth century, and more especially of Walpole's administration; the remainder of the eighteenth century witnessed a rapid increase of money wages, but in consequence of the rise of prices a clecline of wheat-wages; the lowest point was reached between 1790 and 1830 ; in the next thirty years some improvement showed itself, and in the second half of the nineteenth century progress was persistent and rapicl.

Dr. Steffen's arerages cease with the decade 1880-90, and it has not seemed desirable to attempt to bring them to date. For the last fifty years of the nineteenth century, students have at their disposal the elaborate estimates of Mr. Bowley, which on the one hand take acconnt of all available wage statistics, and on the other allow for changes in the general purchasing power of money by (laborate calculations. Mr. Bowley's results for the years $1850-1900$ confirm those reached by Dr. Stefien; they may be summarised in the following table:

. Herage keal Wases as Percontases of the lowel of 1900-04.

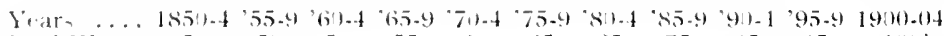

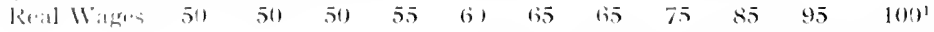

' liowley, " Dictionary of Political Eeonomy," Appendix, Art. Wages. 


\section{APPENDIX II}

\section{BIBI.IOGRAPHY}

VAIUABLE bibliographies are attached to Cumningham's "Growth of English Industry and Commerce." In the following short list of books I have kept in view the comparatively small amount of time which a degree student at most English Universities can devote to the subject.

\section{GENERAL}

Cunningham. IV. Growth of English Industry and Commerce. Rogers, Thorold. History of Agriculture and Prices.

Steffen. G. Geschichte der Englischen Lohnarbeiter.

Special Articles in-

Cambridge Nodern History, edited by Ward, A. W.

Dictionary of Political Economy, edited by Palgrave, R. H. I. Social England, edited by Traill. H. D.

Victoria County History. edited by Page. II.

\section{INTRODCCTION}

Maitland, F. II. Domesday Book and Berond.

Meitzen. Siedelung und Agrarwesen.

Seebohm. F. The English Village Community.

Vinogradoff. P. Growth of the Manor.

\section{BOOK I}

Ashley. WI. Economic History, Vol. I, Pt. I.

Bateson, M. Mediæral England.

Dowell, S. History of Taxation and Taxes in England.

Gross. C. Gild Merchant. 
Ochenkowski. II. I. England's wirtschaftliche Entwickelung im Ausgange des Mittelalters.

Pollock. Sir F.. and Maitland. F. W. History of English I.aw. Vol. I. Schanz. G. Englische Handelspoilik gegen Ende des Iittelalters. Seebohm. F. The English Village Community.

Vinosradoff. P. Growtly of the Nanor.

Villamage in England.

\section{BOOK II}

Ashley. W. Ecomomic History. Wol. I, Pt. II.

Denton. IV. England in the Fifteenth Century.

Dowell. S. History of Taxation and Taxes in England.

Green. A. Town Life in the Fifteenth century.

Gross, C. Gild Merchant.

Leonard. E. Early History of English Poor Retief.

Ochenkowski. W. v. England's wirtschaftliche Entwickelung im Ausgange des Mittelalters.

Prothero. R. Pioneers and Progress of English Farming.

Pryce. W. H. The English Patents of Monopoly.

Schanz, (i. Englische Handelspolitik gegen Ende des Mittelalters.

Shaw. IV. History of Currency.

Sombart. W. Der moderne Kapitalisnus.

Enwin. G. Industrial Organization.

\section{BOOK IIJ}

Andréadés. A. Histoire de la Banque d'Angleterre.

Dowell. S. History of Taxation and Taxes in England.

Hewins. IV. English Trade and Finanec.

Hobson, J. Evolution of Modern Capitalism.

Leonard, E. Early History of English Poor Relief.

Mantoux, P. La Révolution Industrielle an XVIl me siécle.

Nicholls. Sir (i. A. History of the English Poor Law.

Prothero, R. Pioneers and Progress of English Farming.

Pryce, Wr. H. The English Patents of Alonopely.

Shaw, IV. History of Currency.

Sombart. II. Der moderne Kapitalismus.

Inwin, G. Industrial Organization. 


\section{$\mathrm{BO}) \mathrm{OK} 1 \mathrm{~V}^{\circ}$}

Andréadés. A. Histoire de la Banque d'Angleterre.

Brasser. Ld. and Chapian. S. Work and Wages.

Buxton. S. Finance and Politics.

Dicey. A. Law and Public Opinion.

Dowell. S. History of Taxation and Tases in England.

Held, A. Zwei Bücher zur socialen Geschichte Englands.

Hobson. J. The Evolution of Modern Capitalism.

Howell, G. Labour Legislation, Labour Movements, and Labour Leaders.

Hutchins. B. and Harrison. A. History of Factory Legislation. Levi. L. History of British Commerce.

Macleod. H. D. The Theory and Practice of Banking.

Macrosty. H. Trusts and the State. Trust Movement in British Industry.

Mantoux, P. La Révolution Industrielle au XVIII ${ }^{\mathrm{m}}$ siécle.

Nicholls, Sir G. A. History of the English Poor Law.

Prothero. R. Pioneers and Progress of English Farming.

Shaw, IV. History of Currency.

Sombart. W. Der moderne Kapitalismus.

Toynbee. A. Lectures on the Industrial Revolution.

Webb, S. and B. History of Trade Lnionism.

Industrial Democracy. 



\section{INDEX}

$A$

Accol-N-kefpliti, Norman Genius tor, 26

igreements to limit competition, $280 \mathrm{ft}$.

Agriculture, 3 to 14,33 to 46,108 to 121,200 to 204,242 to 245 , $266,338,339,340,344,5$

Agriculture, Board of, 243, 244, 255

Igriculture, capitalism in, 158

Agriculture, commercial, 1 i3

Agriculture, infuence of the market on, $113-114$

Agriculture, large and smatl farms, 256.278

Agriculture, mixed, 116

tgriculture, subsistence, 113 , 258. See Enclosures, 1.anntenure, Open-field system, Shuepfarming, Statistics, Young

Aliens, 93, 95. See Immigration

tha, 152

America, discovery of, 156

American Colonies, the, 188,190, 191. 208

Amsterdam, 204

Anarchs: 263

Anne, 207

Anstm, 74

Antwerp, 157

Apprenticeship, 95, 135, 6, 193, $264,265,266,268,301$. See Child-labour, Gilds

Acuinas, 30

Arbitrage, $15 \overline{7}, 163$

Arbitration, 313,314

Irchitecture, Norman, 24

Arkwright, 208,246

Armorica, 2

Artificers, see Statute of Artificers

Ashley, Professor, 134, 160

lisessment, see Wages

Ansize of bread, 13]

. of bread and ale, 6.̄, 129

$\therefore$ of cloth, $65,93,1.50,194$

of measures, 64

". of novel disseisin, 36

Association, 16, 20, 21, 22, 45, 240, 302

Aulnager, 93, 151,194

Australia, 344

Avecolury, Richard, 94
B

Bacos, 105

Balliti, management of demesne, $109,110,143$

Baliewell, 202, 244, 245

Balance of Trade. See Trade

Balks, 34

Baltic, the, 155

Banks and banking, 220 to 224 , $271,281,317$ to 329

Banti of England, 184, 215, 220, $223,224,275,316$ to 329,334

Bank of England, tet of 1844 , 323,326 ti.

Bank of England discount policy, 281 n., $319 \mathrm{ft}$.

Bank of England monarelical position, 327, 328

Bank of England monopoly, 223, 260, 274, 31s, 328

Bank of England note issues, 226, $228,320 \mathrm{ff}$.

Bank of England, restriction of cash payments, $316,320,335$

Bank of England, resumption of cash payments, 322, 335

Deposit hanking, $157,221,275$, 276.323 ff., 327

Flemish and Italian Bankers, 31

Gold reserve, 275, 32s, 329

Goldsmiths, the, $158,221,222$

Joint Stock lranking, 224, 274, $275,276,281,318,323$ to 329

Note issue, 221, 223, 275, 320 to 329

Note issue, "banking" and "currency" principles, 325 , 326

Note issue, excessive, 320 ff.

Tote issule, one pound, 322, 324, 329

l'rivate banking, 224, 318,323 , 328

Bardi, the, 143

Baring, Sir Francis, 320

Barmo Crisis, the, 328

Becle, 2

Benerolences, t26

Bentham, s5, 235, 236, 237, 239, 274,3013

Beveridqe, Mr.. 333 n.

Bills, international trates, 168

Bimetallism, 316 
Burmingham, 152, 250, 254, 260, '2゙?

Black leath, the, 30,81 to 84 los, 351

Blanket, Thomas, 159

Board of Trade, the, 314

Boiler-makers, thes, 310

Bolinglroke, 190

Bombay, iss

Boon worli, 3s

Booth, Mr., 2y?

Bordarii, 11

Boronghs. see Town

Boultom, 250

Bowler, Mr, 352

Bramals, 251

Bra-sey, Lord, anrl I'rot. Chapman, "Work and Wages," 293, 312

Breteulil, sl

Brielgewater, Wuke of, 253

Bright, 29s. 342, 343

Brindley, 253, 254

Bristol, 68, 134, 144, 150, 15.5, 159. 254

Britain, Roman occupation of, 1, 6

Buckle. 238

Bullion, "xport and import of, 92 . 94, 96, $167 \mathrm{ff}, 188,192,325$

Bullion, supply of in later Middle Ioes, 1 tis 11.

Bullism Committee, report of. 320, 321

Burellers, London, 137

Burlite, 190, 318

Burleigh, 79, 80, 99 to 103

Bye-laws, ser Tomns

\section{(}

C.11 dis staple, the, $153 \mathrm{tt}$.

(allomila, 344

(ambriclecelure, s

('anarla, 341

Camals, 251 tf. 274

(anterluters, 130)

(anvones, 123, 153

(it) route, the, sl, 136

Caputaliom and (apitalists, 49, 53

$54,59,80,84,1+1 \quad 10,161,195$,

$204,211,2633,273 \mathrm{t1}$

(a) makmp. 96

(a) $(1,1), 72$

(atcle, 238

farrom lron Worke the, 2ts 250

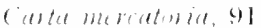

(artwriglat, 24t, 2018

(arad, 150

(itslat warkls, 20)

('а) ? ?
Cecil, 182, 216

Charles $1,157,181,186,216$

Charles [1, 187, 158, 217, 221, 252

Chamberlain, Mr., 292

Change Alley, 225

Chaphin, Mr, 292

Chapman, Prof. See Braney

Charlemagne, 15

Chartism, 301, 304, 306

Chester, 129

Child labour. 267. 268 295 if.

China, 296

Church, influcnce of Xorman Conguest on the, 2s

Church, pioneering ly the, 27. See Monasteries

Claso distinctions, s.5. $86,146,195$. 196, 239, 240. See Status

Class legislation, 1st

Clive, 207, 214

Cloth, early trade in. 34.55 ,. export of, 151, 152. See assize ot

Cloth Industry, 54, 5.5. 56, 60, 61, 93, 96, 149 to $152.2018 .207,247$. $2+5$

Cloth Inelustry, the East Anglian. 150,248

Coth Inelustry, the Wist Country, $1.50,207,247,245$

Cloth fulustry, the West Riding. 160, $195,207,247,248$

Clothiers. West of Englanel, 262

coal, 154, 20s, 248. Serestatistics of

Coalbrookdade J rom Works the, 209. $2+4,244$

Coaration, $5,37,34$

Colxden, 342, 343

Coluten Treats, the. 342

coins. Sier Mones.

colie, 27, 243, 4, 5

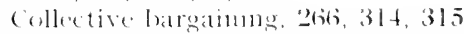

Collectivism, 234, 23s, 282, 283.

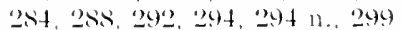

Colonal l'references, 341,343

combinatom, molustrial, 289, 2078. 281,282

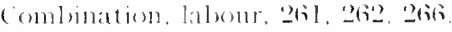
272.300, 302

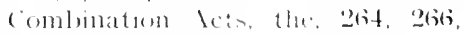
$30)^{2} \mathrm{tf}$.

(ommercial travellers, 27s, 279

fommetle of tratle. $18 \mathrm{~s}$

"Commen employment." thetrine (1), 29,3

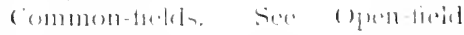
$\rightarrow y>10 m$

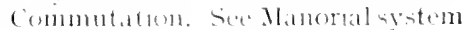


Companies, foreign trate. 156,212, 213.214

jount stock, 2201. 226. $274,275,276 \mathrm{n}$.

Tudor, 137, 13s

Compensation, Workmen's, 293

compensation of vested interests. 100

Conciliation, 313, 314

Co-operation, 23s, 2st ff.

Copyhold. See Land-tenure

Com, town reserves of, 130

Corn, exports, bounties on, 192, 2013 . Laws, 94, 95, 96, 113, 337 ft. .. trade in, 10!2

Cornwall, 3

Cort, 249

Cotsetle, 9, 11

Cottarii, 11

Cotters, 36, 38, 44, 116

Cotton industry, 206, 207, 245, 246. $247,282,295,301,314$

Coventry, $152,247,260$ weavers, the, 134

Craft, medieval conception of a, 127

Crafts. See Gilds

Credit, 215, 223, 227, 317 tt., 32s. See Banks and lanking. Fluctuations

Crises, See Fluctuations, Moneymarket

Crompton, 246

Cromwell, 187, 216

Crusades, 27, 28, 51

Cumberland, 3

Cunningham, Dr., "Growth of English Industryand Commerce.," S6, 101, 102, 157, 161, 174, 158. 199,349

Customs Duties. See Finance. public

Cutlery, 152

Crcles. See Fluctuation:

\section{D}

Dammum emergens, 32

Danegeld. See Finance, public

Danelaw, the, 10, 11

Danes, the, 10, 14

Darbys, the, 209, 248

Darwin, 244

Daris, H. IV. C., "England uneler the Normans and Angevins," 27, 46

Dary lamp, the, 248

Death duties. See Finance, public

Debt, the National. See Finance, public 1)elos, 190, 195

lemmark, $279 \mathrm{n}$.

Derby, 205

I wonshire, 3

Dicer, P'rol., " Law and l'ullic (j)inion," 291

Dickens, 23s, 291

"Our Mutual Frend," 27I

Domesday, \&, 10, 11, 25, 26. See Statistics

Domestic system, the 83,132 to 140 , $141,200,201,257,260,266,268$. $277,278,279$

Dover, 91

Dudley, 209, 210

Dumping. 347

Dinulirli, I8s

Durham, 25?

li

EDEX. 285

Edgar, 64

Edict, Nanten, revocation of, 204

Education, Elizabethan and modern, 239

Edward I, 63, 66, 79, 105, 122, 124, 132, 151, 155 . 175

Expulsion of Jews by, 143

Legislation of, 90, 91, 92

Edward II, Legislation of, 92

Elward III, 63, 86, 123, 125, 150, 151,351

debasement of currency by, 162

legislation of, 92 repudiation of debt liv, 144

Edward IV, 123, 151, 157, 174, 175 legislation ot, 96

Edward VI, 86, 98

legislation muler, 9s

Elizabeth, 79, $86,112,114,139$, $152,157,175,206$, $216,217,226,300,351$ legislation of, 99 to 103 recoinage of, 170

Elizabethan age, contract of modern times with, 238 Imperialists, 187

policy, criticism of, 102. 103

Emption, 72

Enclosures, 41, 42, 43, 84, $115 \mathrm{ft}$., 2010, 255, 257. See Statistics

Enclostures, commission on, 117 
Engineering, Civil, 249, 251, 252 253,254

Nechanical, 249, 250. 251

England, modern and Elizabethan, 238

and Roman Empire. 240

Engroming, 6.5. 93

Entrance to trades, limitation of, 307. 309. See Apprenticeship

Ethics, business, 126

Exchange, the Royal, 225

Exchanges, the foreign. $31 \mathrm{~s}$ t.

Exchequer, stoppage of payment $1, y, 221$

Exchequer bonds, 225

Excise, See Finance, public

Exeter, 134

Exports. See Tradt, foreign

\section{F}

Fabiaxs, the, 312

Factory Acts, 237 n. 294 ti.

Factory sistem, the, 26s. "269. $277,275,302,307$

Factory sistem, the early in-tance of, 160

Fairs, 67, 68. 69

Famines, 331, 332

Farming. See Agriculture

Fawcett, 291

Fens, reclaiming of the 202

Fendal dues. See Finance public

Frudaliom, 23, 24, 25. Set Feudal dues Land-tenure, Rovaldemesne

Fitding, 195, 269

Finance, $143,157,158,220$ to 226. 273 to 276,317 to 329 . See Banks and lianking, credit, Fluctuations, Goldsmiths

Finance, pulbic, 71 to 75,171 to 177 , 215 to 220.334 to 345

linanet, 131)lic, delit, 219, 2201, 334 to $3: 37$

Finance, public detet, conversions, $230,336,337$

finance, public detet, sinking tund. 226,336

linance, pmblie, eptuity, 21s, 347 $3+5$

Finanee, public, Taxes (cutomes dutse, 72, 75, 17:3, 174, 156, 217. 215. 334 to $3: 37$

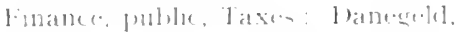
72

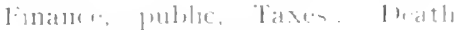
(1110, 335, 34s
Finance, mbic, Taxes: Excise dutie:, 184, 216, 218, 335, 336

Finance, public, Taxes: Feudal dues, 72. 204. 216, 217, 218

Finance, public, Taxes: Firteenth and tenth. 171

Finance, public, Taxes: Hearth, 218

Finance, public, Taxes: Income, $172,335,336,337,347$

Finance, public, Taxes: Land, 172, 218

Finance, public, Taxes: Moveables, 73,74

Finance, public, Taxes: Pensions, $21 s$

Finance, public, Taxes: Poll, I7I, 172

Finance, pulilic, Taxes: Property, 217

Finance, public. Taxes: Roval It ame 71 to $74,174,175$

Finance, public, Taxes: Saladin tithe. 73

Finance, public, Taxes: Stamp duties. 218

Finance, pulbic, Taxes: Subidier, 172,173

Finance, puldic, Taxes: Window, 218

Fish, import of foreign, prohibited, 101

Fitzherbert, 41, 112,116

Flanders, 69, 70, 166

Fimish financiers, 54, 144

$$
\text { Han-e, } 69
$$

.. immigrants, 56, 124, 150

, wite of William I, 27

Florence, 143

Fluctuations, 225, 293, $330 \mathrm{ff}$.

Ford, 209

Forestalling, 6.

France, 15, 25, 70, 183, 187, 190, 263,264

Free socage see Land Tenure

Free temants. see Land Tenme

fiee trade movement. 304. 335 . 3334,337 to 343

Frete tracle movement, effects of, $34+10347$

Free traderts, mincaleulations of, 345,346

Freeholde, see I and Tenure

firescolvalis, the 143

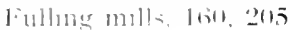

Firlenes, :34

$\operatorname{lin}(1,2), 94,124$

(i) $1111,4,11$ 
Gelleat, 4

Genoa, 155

George, Henry, 31:2

George 1, 1Si

Germany, $6,25,70,2114,343$

Gibbon, "2

Gibraltas, IS\$

Gig mills, 205

Gild funds, contiscation of, 98

Gilds, adulterine, $\overline{50}$

, cralt, $15,49,50,51,53,55$, $82,124,125,131$ to 140

, apprentices, 134, 135 , 136

,. journeymen, 132, 134, 135

, masters, 132, 134, 135

. regulations of, 125 to 128

merchant, $15,16,44$ 20 57 . 67,124

Gladstone, 336,337

(ilove-making, 152

Cioklsmiths, 91, 137, 158, 221, 222

Goschen, 337

Green, Mrs., "Town Life in the XVth century," 68, 123, 15.5

Gresham, 88

Ground-rents, connection with growth of capitalism, 145

Guardians, Board of, 290, 291

Guinea, the, 227

Gun-powder, 10]

$\mathrm{H}$

HANOVER, 185

Hanse, the Flemish, fo

Hanse, the German, $1 . \overline{5}$

Hargreaves, 246

Hastings, Warren, 214

Headlands, 34

Hearth tax, the. See Finance, public

Heathcote, 247

Hennegau, 69

Henry I, 71,72,74

Henry II, 65

Henry III, 62, 65, 7 I

Henry IV, 155

Henry VII, 98, 105, 132

Henry VIII, s7, 9s, 163, 170, 175, 215

Hewins, Professor, "English Trade and Finance," 182, 195., 34911 .

Hide, the, 36

Hohson, Mr., " Evolution of Modern Capitalism," 187, 275
Hollikam, 243, 244

Holland, $1 \leqslant 7$

Homestede, the seattered, 3, 4

Horrockis, $2+6$

Hull, 144, 155, 284

Hinne, 190

Hume, Josephl, 304

Huntsman, 249

Huskision, 272 n., 334

I

1MMIGRATION of stilled wortiers: alter Norman Conquest, 25, 56 under Edward I, 92

in XVIth century, 152 III, 124, 1.50

in XVIIth and XVIlth centuries, 204

Income taxes. See Finance, public India, 187, 188, 189, 206, 207, 214, 293 n., 331

Indigence. See Poor Law

Individualism, 234 to $239,287,288$, $303,306,312$

Ine, 9

Insurance, 225, 277 sea, 157

Interest, 87, 157, 198, 222. See Usury

Interregnum, the, 193

Intimidation, 307

Inventions, 204 to 208,242 to 260

Investment, 224, 232, 273, 274

Ireland, 3, 190,191, 206

"Iron and Trades Review," the, 281

Iron industry, 209, $248 \mathrm{ff}$.

,. ., combination in the,

Italy, 70, 155 281,282

\section{J}

JACuCARD loom, the, 247

James 1, 152, 181, 216

Jenny, the spinning, 246

Jevons, 330

Jews, the, 31,73

expulsion of the, 175

wealth of, in Xilth century, 143

John, 73

John, toreign loans ot, 143

Johnson, 246

Joint Stock. See Bankis and hanking companies

Joplin. 323, 324

Journeymen. Siee Gilds 
Just price theory of, 29, 30, 31, 87, si 126

Ju-tice of the Peace, s0, $82.99,186$. 143. 194, 264, 265, 2711.296, 300

K

IATHARINE of Braganza, IS

liay. 2015. 245

I'-ndal. 1.51

Kent, 3

ling (iregory. 199. 201

L.

1.AEutr Copartnership Amociation. $2 \times 6$

Labour dues, temurial, 110 to 113

Jaboum laws, 82. 85, 92. 94. 97. 114 3.51. See Asesoment, Combinatuon Acts, Poor Law statute of Artificers. Tracle [ nioniom

Laisse, fain 105, 106. 183, 193. $234,266,297$

Lanca-hire, 254, 26.5, 2\$2

Land taxes, See Finance, gublic

Lancl-tenure, 23

Coptholds. 3.5. 114. 120

Customary holkers. 117 to 120

Free socage, 35

Free tenants. 11, 12 , 35

Freetiold $2,2(m)$

Sere Arronlture, 1andowners. leanes. Landlords. Manorial srotem. Royal demesme. Villains. Yeomen

Landiord 27 44, 109 to 120 . 201. 2112. 244. 254. 256. 249. 335 to $341,344,345$

Latitundium, 6

Leater, 1019, 110, 254, 255, 257

$1+1+2,240$ -treck and land. 4.5. 1111

I. Int, olders ande of, ordered, 101

Letant the , 14.5, $15 \overline{5}$

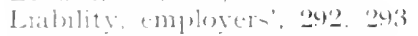

l.m+n malu-try. 2016. 247

Jinerpent, lag

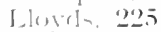

1.x $140.147,227$

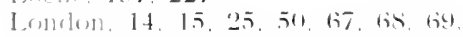
sis. $41,133,124,131,134,136$ 137.144 150 154 157 195 $234254,274,2812901310,317$ 3' 32.324

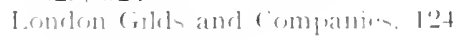
$1: 3+14,135,14,5$
Louin Plilipue. 342

Low countrie- the. See the Jetherland.

Lownder, 227

Luica, 143

Lumbur essans, 32

MACADAI, 252

Nachinery, 2018, 245 t1. 264. 265.

295. 301. 302. 317. 319,315

fencing of 297

Government: opposition of. $96,205 \mathrm{tf}$.

JeCuItoch, 245 ser Invention-

Macleod, $318 \mathrm{n}$.

Macrosts. Mr. 2sl n.

Yagna Curta, 64, 66, 69, 73, 1501

Maitland. is

Jalthus. 2sis

Manchester. 152 268. 295

Mlanor. deserijutions of the. $\overline{7}$. su

Manorial instem, the $7,9,33$ to 46 . si fit. 10 s to 121

llanorial syotem, the, and communism. 34

Manorial system, hre, commutation of dues, 3s. 43,109 to 113

Manorial ristem, the; court, 26 , 41. 41

Janoral sretem, the cutom so. Ste Yillain Bailite

Namures, 243, 244

Jarkets, 67, 6s. 129. 27s. See Agriculture. Town -

Narlborough, 1sis

Marthall. 1)r. 29s n.

Marx, 2stio, 3!2

Mason- 5.9

Waullay 251

Mal, 152, 157

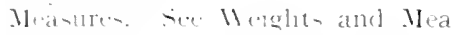
-

Wertitertanean, the. Iss

Wenan. "Igrar-und siedelungnwer.h., 3

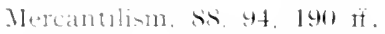

cricism of, 103 to 107

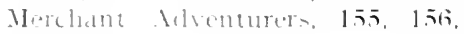
213

Werchet, 3s

1]erton, tatume of t2, 116

Metealt 222. 20-3

Vethen treaty. Isti, lss, Ian

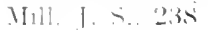


Mining, 161, 208

Mining 1el, 24s, 24t

Minoria, 1si

Monasteries, discolution on sis. 98 117,175

Momey, 14, 43, +4, 62, 63, 6it, 162 to $170,226,227,228,316$. 317. Sere Ratio and wealth, iclentification of, $29,19^{\circ}$

market, 166 tf., 281, 329 tt.

Monometallism, 3]6

Monopolies, 176, 182, 18:3, 1st

282, 283. See statute of

Jontfort, simon de, 93

More, Sir Thomas, 1711

Noveables. See Finance, guble

Mule, the, 246

IInn, 190, 192, 197

Municipal and municipalitien. See Tomins

NAMOLEON, 26 it

Napoleon III, 34'

Nationabisin, 79, 346

Britinl besinnings of 191

linglish, 74

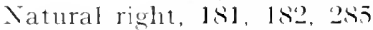

Xavigation Acts, 95, 46, 1111, 157. $188,3+1,3+3$

Navy, the roval, 175, 26s

Vetherlands, 27, 69, 1.5

New Lanark, 274. 20st

New Vorld, the, sl

Newbury, Jack of, 159. 160

Newcastle. 154

Netrcastle "Vend," the. "260)

Newcomen, 2019, 20̄7)

Norman Conrfuent, resiltio oi, "2t to 28,47

North, Lord, 334

America, 1s7, 184

North-west passage, 206;

Northcote, Sir Statiord, 3:37

Norwich, 96, 150

Novgorod, 1 ถ

\section{()}

OASTLER, 297

Open-field syotem, 3, 4, 33, 34, 35 $36,41,42,114,115,116,200$. 243, 254. See Agriculture, Enclosures

Ordnance, $11+1$

Oresme, so

Out-relief, 268, 2sis it.

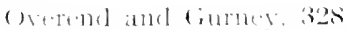

(1wen, Roluet, 237, 272. 274, 284

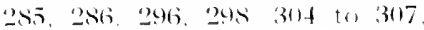
312

1 '

P'ANTERS, the Lomelom, 1:37

l'alal taxes, lhe, 14 "2

Paris, 249, 250

l'atents, 101, 16:1, 18'2, 211, 216

l'ater:on, 20:3

Paul, 20s

l'alperism, 40, sl ti, 271, 271. See Out-reliet, l'on law, speenhatmland

Peasants' Revolt, the, s.̌., 111, 1:34

l'eel, 326, 335, 341)

Pensions, ofel age, 292

Percival, Dr. 26s

lersid, 206

1'etts, 19s, 203

Picketing, 311,312

Piere lists, 26.5, 3018, 314, 315, 316

Pin-makines 152

Pioneers, the Rochalale. 2st, 2sis

l'itt, 1901, 236, 334, 335, 337

Place, Francis, 261, 3013,304

Pole, l)e la, 144

poll taxes. See Finance. pulsle

l'ooling, 280

loor 1,aw, the, 97 to 100, 185, 193.

$144,236,237,238$

266, 268 to 272, 234t.

commison, the, 271 .

$289 \mathrm{tt}$.

experments in towns. 123. see l'auperism. Settlement law

Rate, 21s, 2กิ 339, 340. Sem Sitatisticn

l'ort(t), 252

l'ortugal, lss

l'opulation, dintrilution of, 12 2333 Sec Sitatister

I'risatere to

P'rinast, 72

Production, instruments oi, 2(i2) larefe cale, 1, So to 161 204. 210, 211, 231.

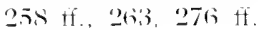
$31: 3$

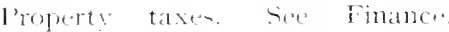
public

Prompectus, investors attracted lis. 274.275

Irotection, 45. 46, 11)1, 114, 151, $190 \mathrm{ff}$ See com exports, Corn law, Free trate. Landlome. Mercantilinm, sliding-scale, Tarift 
Protectorate, the 2014

Fryce, Mr.. "English Patents of Wonopoly," 101

l'nrverance, 217

Prm, 216

R

RADCLIFFE, 240

Ralwars, 251, 274, 277, 314

Raleigli, 211

Ratio between cold and -ilver, 163 if., 227,316

Rubellion, the 1st. 1s5

liectutudinessingularumpersunarm, $9,11,12$

Reere, futies of the," 13

Regrating, 6.5

Reliefs, 36, 38

Rent, 24, 339, 3401

Retoration, the 157, 1S8, 193, 194, $203,209,216,217,218,222$

Restraint of trade, 310

Retail shols, 279

Revenue, see linance, pulslic Revolition, the English, 184, 185, $184,200,216,220$, 223,226

the French, 302

The Industrial, 136 , $224,226,231$ to 272

The Incluntrial, antecerlentsot, 181 to 228

the Industrial, summary of its achievements, 232, 233

Revnolds. 2019

Riblum, mechanical weaving of, 205 Ricarto, 198, 223, 2867, 322

Richard I, 64, 73, 1 .31

Richarel 11, 105

$$
\text { leginlation of } 94.45
$$

Roads, 1, 636, 132, 201, 251, 252

Rochrlate. 2st

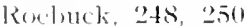

IRogers, Thorolel, 96, $111,349,350$

koll of the l'ipe, the , 26, 50

Remalns in Britand 1 , to

Rotation of cropse. $2-13,244$

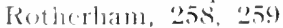

Romen, 1.5, 2.5

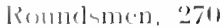

Roval demestre, Sier Finanere, public

Ruskin, 23s

kstweli, prate of, '2zol

SADIR:R, 2UT

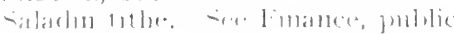

Salt, 101

sarery, 208

Saxon Conquest, 1, 2, 3

Scandinavia, 14,155

science, influence of, on economic studies, 198, 199

science, influence of, on inventions, 210

schools, 146. See Education

scotland, 19], 323, 327

seli-seeling, 84,85 .

stulor, 289, 29s

Serfelom, origin of in England, 5,6

settlement Law. 194. 300

Shaftesbury, 297, 299

Shakespeare, s8

Sheep-1arming, 27, 83, 84, 98, 1112, 113 to $118,244,245$

Shetfield, 152, 249, 260, 310

Shetburne, 190

Sheriff, the, $71,72,74,75$

Shipping, rise of English, $153 \mathrm{ff}$.

"Shirler," 248, 307

Shots. 34

Shuttle, the flying, $205,208,245$

silk industry, 205, 206, 247

sinking-fund. See Finance, public

slaves, 11

.. negro, 1se. Sie Trade, slave,

slicling-scale, $340,344 \mathrm{n}$.

Smeton, 248

Smith, Aclam, 19, 181, 190, 198 $203,2(18,226,235,234,237,273$, 31)1, 307 n., 347. See "Wealth o1 Nations.'

Socialism, and socialists. 237, 239, $240,286,287$

Christian, 286, 312

" municipal, 2\$2, 2\$3, 287 see Collectirism

Sickemen, 11

Sombart, l)r. 1 t2 tf.

Southsea Bublule, the, 225

Sollthampton, 152

spanish colonices, the, 187

Spexthamlanel, 236, 269, 270

spencer, Ilertert, 23s

spitaltields, 300

sitaltordsluire, 2019

Stamp duties, Sere finance, pubite

staple and staplers, the, 71, 153 ff.

stateh, 101

State-intervention, 106, 234 tf.,

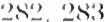

statistics, lys

agricultural classese

Goth rexperts, 151

(c)al ontput, 20(1) 
Statistics, Ifomentay, 11, 12, 13 enclosures. 250 foreign tracle, 343,344 national delet. 20 (1).33t to $: 3,37$

poor-rate. 269

population, 12, 42, 108, 233

taxation, 218,334 to 337

wages, 349 to 352

Status, 21, 22, 79

Statute of Artificers, 99, 13.5, 136. $185,193,194,264$

Statute of Merton, 42, 116

Statute of Monopolies. 204

Statutum de falsa monetu, 91

Steam-engine, the 20s, 210, 24s tt.

Steelyard, the, 1.56

Steffen, Dr., 349 it.

Steplien, 63, 72

Stephenson, 248, 251

Stock Exchange, the. 225. 275, 27s

Stocking machine, the 205,206

Stockjobbing, 225, 221

Stourbridge, 67

Strafford, 181

Strathclycle, 3

Sturtevant, 209

Sumptuary laws. 92

Sun-spot variations. 334

Surrey, 152

Sussex, 152

Sweating, 147, 262, 278

\section{T}

TACITl's, is

Taft Vale, 312

Tangier, 188

Tarift, the, 88, 18.7, $186,237,238$. $272,335 \mathrm{ff}$. See Customs duties. Exports, Free trade. Protection. Taverner, John, 155

Taxation and Taxes. See Finance, public ; Statistics

Telford, 252

Ten hours day, 297

Thanes, 9

Three-field system. See open-field Tillage, 101,114 to 118,192 . See Agriculture, Enclosures

Token coins. See moner.

Tomn-Knowles, Mrs., 102

Tooke, 298

Tories, the, 189, 190,237, 272. 337

Towns, $1,2,15,22,47$ to 61,811 to 84,122 to 140 affiliation of, 51

," aristocracy in, 133

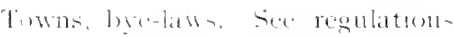
common tielike of 15,44 129

communal action, 129

concentration $111,234,311$

decline in importance of, 123, 124

derelopment of. stages in. 4ㄴ, $53,54,55,56$

srowtl of capitaliom in. $1+6$

influence of Black leathon 52, 122, 123

municipal enterprise, 129 130. 238

regulation in, S1), 125 to $1: 31$

relet of poverty in, 12:3, 130. 131

Townshend, 202, 243, 244

Tornbee, 231

Trade, balance of, 85, 93, 94, 101 . 16 s' to $170,196,197$

bills, 168

coal. 1.54

domentic, If, 33, 43, 44, f7 to 61,65 to $68,80,82,89$

$104,120,122,130,132$. $133,137,1+1$ to $1.32,18$. 242,278

foreign, 14, 15, 27, 28, 6s to $71,80,88,164,129,152$ to 157.185 to $18 \mathrm{~s}, 211 \mathrm{to}$ $214,234,344,341$

slave, 214

wholenale. 12s

Tradennion movement, the, $3019,31,5$

Tratle nnionism. 201, 237, 238, 239, 3019 to 315

leefore Industrial Revolution, 307 collective bargam ing, 30 sf.

commission of 1867,3111

conspiracs, 314 , 311

employers and. 313

fecleration of, 313

legal existence of. 311,312

relation of crattgilds to, 139

restriction of, 97

the "New Monte," 3116

Trades councils, 310

Transport, 259, 260, 274, 301, 307. see (anials, Railways. Roads 
Truck. 145

Trust morement tine 347. Set (comlnnaturn, Indlu-trial

Tuche jerade heriatiom durine the thi th 1113

liall 2012 243

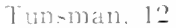

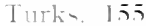

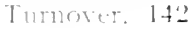

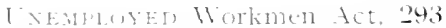

("i)emplovencent, 47, $1111,266,293$. 333 - T.e.tur Latw

[ inter] statem. 34]

Inmen. Mr..' Indlustral Urganizat10n, " l112 133. 137, 145, 159

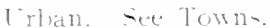

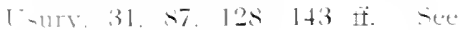
]nterte-t

I tolisa," is

Itrecht, grace at list 154 194. 20

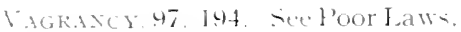
Labumin Lam-

Ience, 155

fented interets. eompensation of. 106

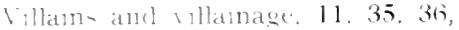
$411+1$ 43. 53. sis 110 to 113. 117 (1) 1211. Se. Manorial Sy-tem

Iillamum, I1 12

Vimogradott, l'mot.. 37

Vireate, 36, 37, 3⿻, 34

Virgater, $36,37,35,4$

\section{1}

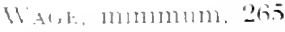

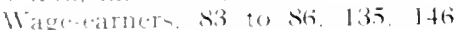
(1) 144,144 ti. 261il to 272, 301

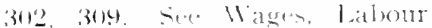

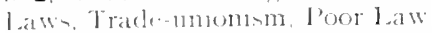

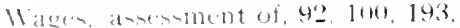

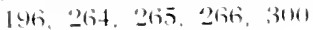
listort of. 349 to 352

11 aldin 3

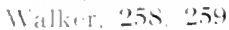

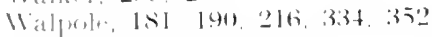

II atrulerolute 54

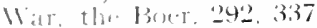

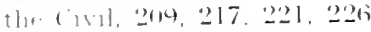

161, (romean, $214,336,337$
War, the great Frencls. 233, 234.

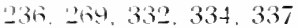

the Hundred Tears", sil, s3, $1+4,155,156$

the seren Years, 189,200 334

War- of the Rotes, the s3, 144, 163. 17.5

Marde and liverice, court ot, 216

Water-trame. the, 246

Matemays. 6ro

Watt. 2019. 24s to 251

Watts, 1). 196

Wealth, medieval view on, 2s, 29 Wealth of Xations." the. 3111. 334 to 337

IVtavers" tct the 159

15edermod, 210

Weeli worli, 3S

Vieght - and nuanures. 14. 64 it. -

$110 \sin , 9$

$11 \mathrm{e}-\mathrm{t}$ Indies, $157.252 .3+1$

II - t Riding. 2š2. see cloth industry

Vie-tmortand, 3

Whigs, the 185, 159, 190, 192, 27:2, $33 \%$

Whitington. 144,147

Miglet, Inle of, st

Wilkinion, 20in

William 1. 72, 74

William IlI. $15 \mathrm{~s}$

William JV. 269

Winclicombe. fohn, 15y, 160

Ninclester. 15

Nindow ylas, 111, 352

Ninclow Tax. See Finance, public $1101-9,951,167,173$

Wool, exports o1, 27, 43, 151, 203. sece (un-toms duties

Woullen Inslustry. See cloth Indin-try

Workliounte te-t, the, 144, 269

Workiner clase. See Mage-carners

IV)ate. 20s

I

YARDIAXr, 9, 336. See Virgate

Jandemen, 94

Yarrantore. 20?

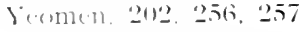

Sink $13 \%$

Sorkline, 143, 245. 254

Yimnu, Irthur, 243, 248, 254, 25.

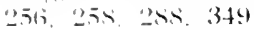






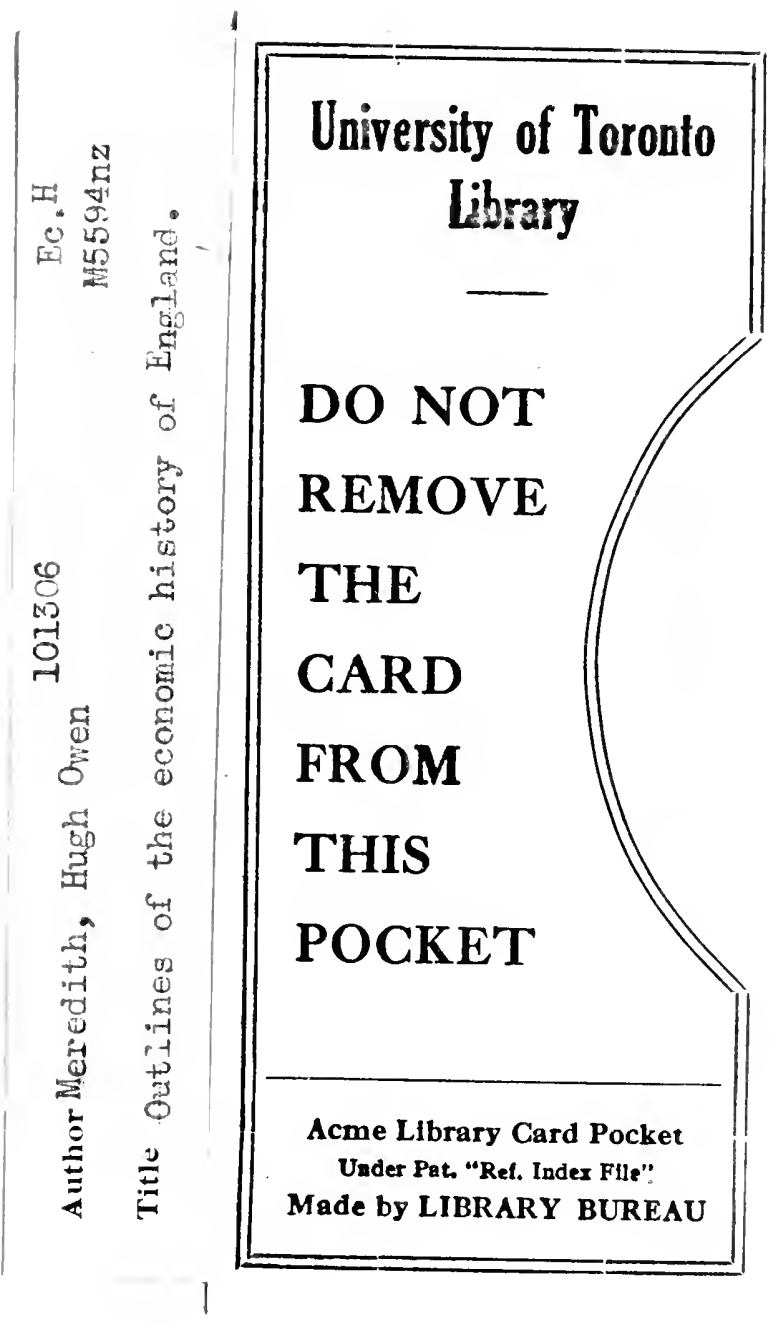




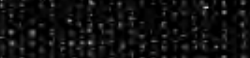

4as

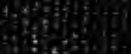

(A)

3.9.4)

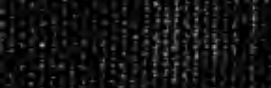

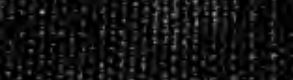

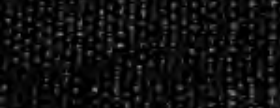

E.

4.

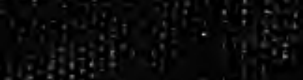

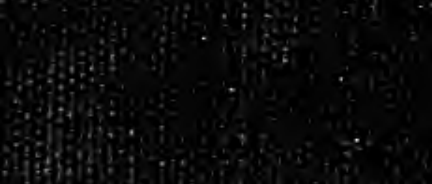

as

ats

20

3.

a

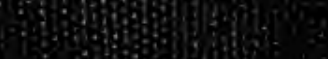

$8 \times$ a

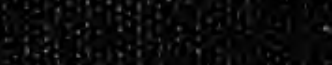

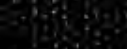

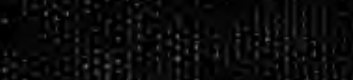

6 ats 1) 90.

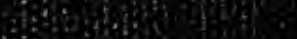
19is

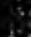
(ivitis 